\title{
Abordagens para o problema de dimensionamento e sequenciamento da produção em indústrias integradas de papel e celulose \\ Marcos Mansano Furlan
}



Data de Depósito:

Assinatura:

\section{Marcos Mansano Furlan}

\section{Abordagens para o problema de dimensionamento e sequenciamento da produção em indústrias integradas de papel e celulose}

Tese apresentada ao Instituto de Ciências
Matemáticas e de Computação - ICMC-USP, como
parte dos requisitos para obtenção do título de
Doutor em Ciências - Ciências de Computação e
Matemática Computacional. EXEMPLAR DE
DEFESA

Área de Concentração: Ciências de Computação e Matemática Computacional

Orientador: Prof. Dr. Reinaldo Morabito Neto Coorientadora: Profa. Dra. Maristela Oliveira dos Santos 
Ficha catalográfica elaborada pela Biblioteca Prof. Achille Bassi e Seção Técnica de Informática, ICMC/USP, com os dados fornecidos pelo(a) autor(a)

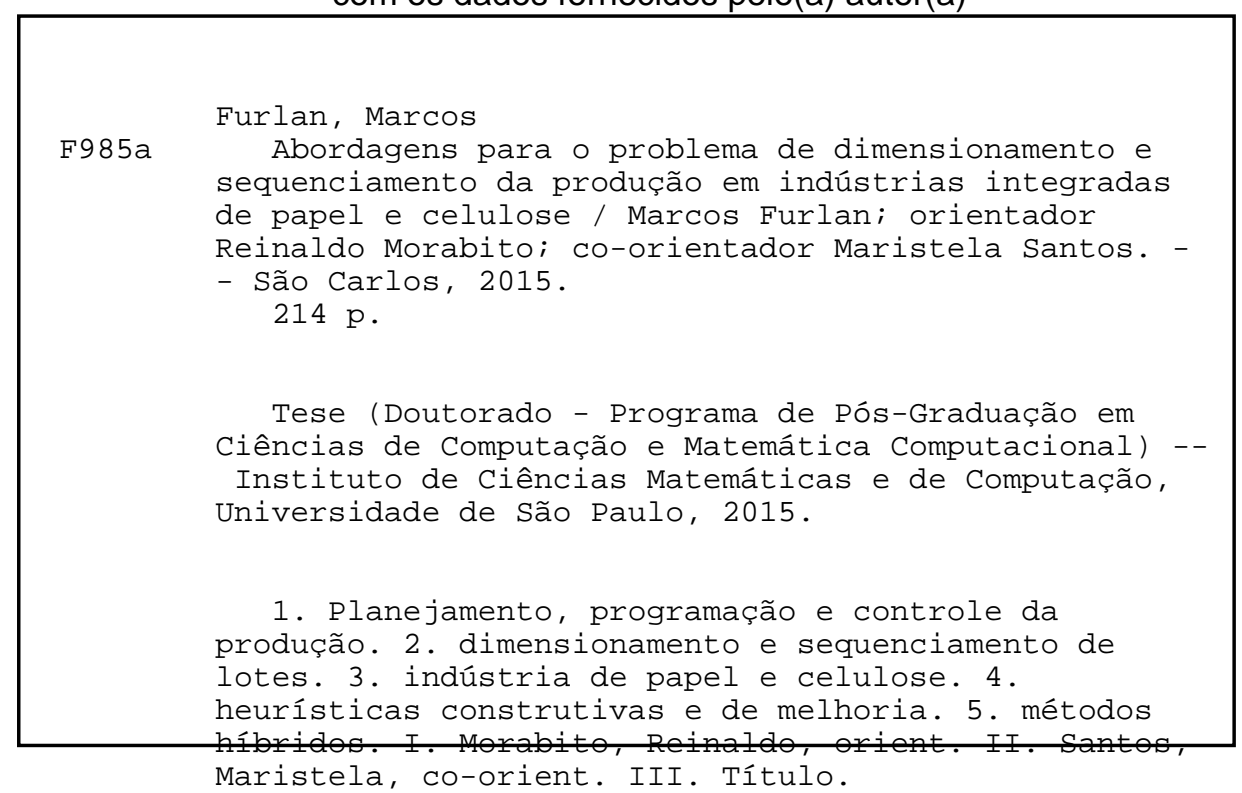




\section{Marcos Mansano Furlan}

\section{Approaches for the lot sizing and scheduling problem in integrated pulp and paper mills}

Doctoral dissertation submitted to the Instituto de Ciências Matemáticas e de Computação - ICMCUSP, in partial fulfillment of the requirements for the degree of the Doctorate Program in Computer Science and Computational Mathematics. EXAMINATION BOARD PRESENTATION COPY

Concentration Area: Computer Science and Computational Mathematics

Advisor: Prof. Dr. Reinaldo Morabito Neto Coadvisor: Profa. Dra. Maristela Oliveira dos Santos 

O setor industrial produtor de papel e celulose tem aumentado sua relevância comercial nas últimas décadas devido à demanda constantemente crescente. $\mathrm{O}$ aumento na competitividade do setor gerado pela economia globalizada e a dificuldade de desenvolvimento de bons planos de produção em ambientes produtivos cada vez mais complexos têm motivado a pesquisa por novas e efetivas ferramentas de auxílio à tomada de decisão. Considerando estas dificuldades, abordamos neste trabalho o problema de dimensionamento e sequenciamento de lotes com foco em empresas com processo integrado de produção de celulose e de papel. Trata-se de um problema de planejamento de médio a curto prazo, geralmente com maior enfoque no curto prazo por considerar o planejamento detalhado da produção em horizontes de planejamento que não superam 30 dias. No processo integrado de celulose e papel, foram consideradas as decisões de produção do digestor, evaporador, caldeira de recuperação e de múltiplas máquinas produtoras de papel, além do controle de estoque de produtos intermediários e finais. Modelos matemáticos da literatura foram modificados e estendidos para incorporar características adicionais do problema como, por exemplo, processos com múltiplas máquinas de papel. Além disso, foram desenvolvidas heurísticas construtivas, heurísticas de melhoria, abordagens de solução híbridas baseadas em algoritmos genéticos combinadas com ferramentas comerciais de solução exata, além de combinações entre os métodos. As abordagens desenvolvidas foram testadas computacionalmente e as melhores combinações de métodos foram definidas. De forma geral, os resultados dessas abordagens foram superiores aos obtidos por ferramentas de solução comerciais puras. Ademais, a variação proposta da heurística de melhoria fixe-e-otimize com mudanças na função objetivo se destacou com relação aos demais métodos, obtendo os melhores resultados, independentemente da qualidade da solução inicial utilizada. As principais contribuições desta tese são a apresentação de modelos matemáticos para repre- 
sentar apropriadamente o problema estudado, e o desenvolvimento de métodos de solução efetivos para resolver o problema.

Palavras chave: planejamento, programação e controle da produção; dimensionamento e sequenciamento de lotes; indústria de papel e celulose; heurísticas construtivas e de melhoria; métodos híbridos. 
The pulp and paper industry has been increasing the commercial importance in recent decades due to the constant growing demand. The increasing competitiveness of this sector generated by the globalized economy and the difficulty to develop good production plans in complex production environments have motivated the search for new and effective decision support systems. Given these difficulties, in this thesis we address the lot sizing and scheduling problem focused on integrated pulp and paper mills. This is a problem of medium to short term planning, generally more focused on the short term as it covers detailed production schedules in planning horizons which do not exceed 30 days. In these integrated pulp and paper process the production decisions of digester, evaporator, recovery boiler and multiple paper machines are considered, apart from the inventory control of intermediate and final products. Mathematical models known in the literature were modified and extended to incorporate additional features of the problem, such as processes with multiple paper machines. In addition, constructive and improvement heuristics, and hybrid methods based on genetic algorithms combined with a commercial solver were developed, as well as combinations of these solution approaches. The methods developed were computationally tested and the best combinations of methods were defined. Overall, the results of these methods were superior to the solutions obtained by pure commercial solvers. Moreover, the alternative variation proposed of the improvement heuristic fix-and-optimize with exchanges in the objective function surpassed the other methods, obtaining the best results, regardless of the quality of the initial solution used. The main contribution of this thesis are the presentation of mathematical models that appropriately represents the problem under study, and the development of effective solution methods to deal with the problem.

Keywords: production planning and control; lot sizing and scheduling; pulp and 
paper industry; constructive and improvement heuristics; hybrid methods. 
2.1 Panorama brasileiro e mundial do setor $\ldots \ldots \ldots \ldots$ p. 9

2.2 Área florestal, produtividade e tipos de celulose . . . . . . . p. 10

2.3 Processos produtivos de celulose e papel $\ldots \ldots \ldots \ldots$ p. . . . . . . . 12

2.3.1 Produção de celulose e recuperação de resíduos . . . . . . . . p. 12

2.3.2 Produção de papel . . . . . . . . . . . . . p. 15

2.4 Visitas técnicas em empresas produtoras de papel e celulose $\ldots \ldots$ p. 16

2.4.1 Empresa produtora de celulose solúvel especial situada na Bahia p. 17

2.4.2 Empresa produtora de papel e celulose situada em São Paulo . . p.19

2.4.3 Empresa produtora de papel e celulose situada em Portugal . $\quad$ p.22

2.5 Problemas revisados na literatura . . . . . . . . . p. 24

2.6 Descrição do problema abordado $\ldots \ldots \ldots \ldots \ldots$ p. . . . . . . . . . . . 
3 Modelagem matemática $\quad$ p. 39

3.1 Revisão de modelos da literatura . . . . . . . . . . . . p. 39

3.2 Modelo matemático de Santos e Almada-Lobo (2012) . . . . . . . . p. 43

3.3 Modelo matemático de Figueira et al. (2013) . . . . . . . . . p. 51

3.4 Modelo matemático proposto $\ldots \ldots \ldots \ldots$ p. 55

3.4.1 Restrições de limitação de itens produzidos . . . . . . . . . . p. 62

3.4.2 Restrições de limitação na troca . . . . . . . . . . . p. 63

3.4.3 Restrições de geração de ciclos . . . . . . . . . . . . p. 64

3.5 Testes computacionais preliminares $\ldots \ldots \ldots$ p. 67

3.5.1 Exemplares de teste utilizados . . . . . . . . . . p. 68

3.5.2 Definição dos limites de trocas em cada máquina de papel . . p. 69

3.5.3 Divisão dos itens produzidos em cada máquina de papel . . . . p. 69

3.5.4 Limites de topo e base de ciclos . . . . . . . . . p. 70

3.5.5 Resultados preliminares ................. p. 70

4 Heurísticas construtivas e de melhoria p. 91

4.1 Heurística construtiva gulosa . . . . . . . . . . . . p. 92

4.1.1 Método de definição de velocidades de trabalho do digestor . . . p. 95

4.1.2 Heurística gulosa de melhoria da sequência de produção . . . . . p p. 97

4.2 Heurística construtiva baseada em arredondamento $\ldots \ldots$. . . . . 98

4.3 Heurística construtiva baseada em ciclos predefinidos de produção . . . p. 100

4.3.1 Ciclos de produção utilizados . . . . . . . . . . . p. 102

4.4 Heurísticas do tipo relaxe-e-fixe . . . . . . . . . . . p. 103

4.4.1 Particionamentos das variáveis de decisão do digestor . . . . . p . 106

4.4.2 Particionamentos das variáveis de decisão das máquinas de papel p.109

4.4.3 Combinações desenvolvidas . . . . . . . . . . . . p. 114

4.5 Heurísticas do tipo fixe-e-otimize $\ldots \ldots \ldots \ldots \ldots$ p. . . . . . . . . . . . 
4.5.1 Particionamentos das variáveis de decisão das máquinas de papel p. 117

4.5.2 Fixe-e-otimize tradicional . . . . . . . . . . p. 120

4.5.3 Fixe-e-otimize com mudança na função objetivo . . . . . . . p p. 123

5 Método híbrido $\quad$ p. 127

5.1 Representação do indivíduo . . . . . . . . . . . . . p. 131

5.2 População inicial . . . . . . . . . . . . . . . . . . p. 133

5.2.1 Soluções iniciais não aleatórias . . . . . . . . . . . . . . p. 134

5.3 Medida de dispersão de frequência dos alelos (FSM) . . . . . . . . . p. 134

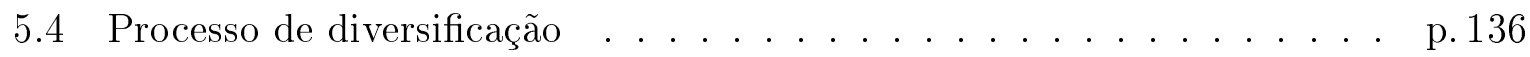

5.4.1 Ajuste de parâmetros . . . . . . . . . . . p. 137

5.5 Decodificação e avaliação de aptidão dos indivíduos . . . . . . . . . p. 140

5.5.1 Tratamento de infactibilidades . . . . . . . . . . p. 142

5.6 Operador de cruzamento . . . . . . . . . . . . . p. 143

5.7 Operadores de mutação . . . . . . . . . . . . . . p. p. 144

5.7 .1 Resumo das mutações . . . . . . . . . . . . p. 150

5.8 Operador de seleção . . . . . . . . . . . . . . . . p. 151

6 Testes computacionais $\quad$ p. 153

6.1 Exemplares de teste gerados . . . . . . . . . . . . p. 153

6.2 Parametrização do Cplex . . . . . . . . . . . . . p. 158

6.3 Parametrização dos métodos desenvolvidos . . . . . . . . . . p. 162

6.3.1 Heurística construtiva gulosa . . . . . . . . . . p. 163

6.3.2 Heurística construtiva baseada em ciclos predefinidos de produção p. 165

6.3.3 Heurística relaxe-e-fixe . . . . . . . . . . . p. 166

6.3.4 Heurística fixe-e-otimize . . . . . . . . . . p. 170

6.3.5 Algoritmo genético ....................... p. 184 
6.4 Resultados computacionais finais . . . . . . . . . p. 186

6.4.1 Comparação de desempenho das heurísticas construtivas . . . . p. 186

6.4.2 Comparação de desempenho dos métodos de solução . . . . . p. 188

7 Conclusões e perspectivas $\quad$ p. 199

$\begin{array}{ll}\text { Referências Bibliográficas } & \text { p. } 207\end{array}$ 


\section{Lista de Tabelas}

1 Resumo dos trabalhos com problemas relacionados a indústria de papel

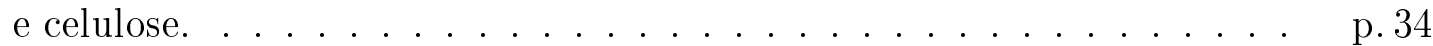

2 Dados e variáveis utilizados nas três plantas produtivas. . . . . . . . . p. 45

3 Dados e variáveis relacionados a planta de celulose. $\ldots \ldots \ldots$ p. . . . . 46

4 Dados e variáveis relacionados a planta de papel. . . . . . . . . p. 48

5 Dados e variáveis relacionados a planta de energia. . . . . . . . . p. 50

6 Dados adicionais da planta de papel. . . . . . . . . . p. 52

7 Dados e variáveis relacionados a planta de papel com múltiplas máquinas. p. 58

8 Combinações de particionamentos da heurística relaxe-e-fixe testadas. . p. 115

9 População com 6 indivíduos, 3 genes e 3 diferentes alelos. . . . . . . . . p. 135

10 Frequência dos alelos $(\operatorname{freq}(s, g(s, i)))$ da população apresentada na Ta-

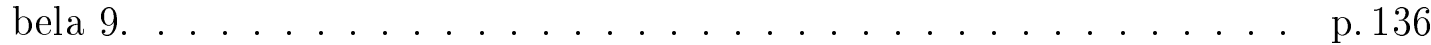

11 Resumo das mutações desenvolvidas. . . . . . . . . . . . . . p. 151

12 Funções para calculo de perdas e tempos de preparação de máquina. . . p. 156

13 Cenários utilizados para a geração de exemplares de teste. $\quad$. . . . . . p. 157

14 Valores em porcentagem (\%) correspondentes a cada nível de carga por

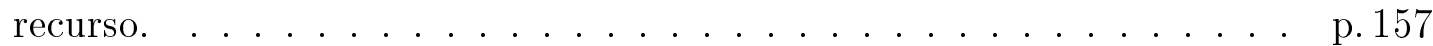

15 Desvio percentual das soluções da heurística gulosa. . . . . . . . . . p. 164 
16 Desvio percentual das soluções da heurística baseada em ciclos. . . . . p. 165

17 Combinações de particionamentos utilizados. . . . . . . . . . p. 167

18 Valores utilizados para fixação e sobreposição nos 60 particionamentos testados. . . . . . . . . . . . . . . . . . 168

19 Quantidade de soluções factíveis encontradas por cada variante da heurística relaxe-e-fixe. . . . . . . . . . . . . . . . . . p. 169

20 Conjunto de parâmetros das 36 variantes de fixe-e-otimize testadas. . p. 171

21 Desvio percentual médio (\%) das variantes do método FT-HCG. . . . . p. 173

22 Desvio percentual médio (\%) das variantes do método FT-HCBC. . . . p. 174

23 Desvio percentual médio (\%) das variantes do método FFO-HCG. . . . p. 176

24 Desvio percentual médio (\%) das variantes do método FFO-HCBC. . . p.178

25 Desvio percentual médio (\%) dos 36 conjuntos de parâmetros testados considerando a solução da heurística RF21 limitada em 1800 segundos

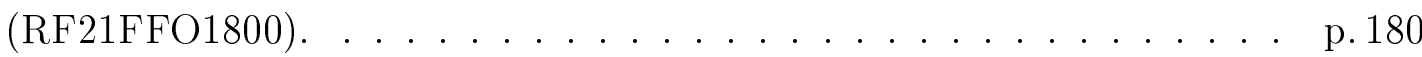

26 Desvio percentual médio (\%) dos 36 conjuntos de parâmetros testados considerando a solução da heurística RF21 limitada em 3600 segundos.

27 Desvio percentual médio (\%) dos 36 conjuntos de parâmetros testados considerando a solução da heurística RF33 limitada em 1800 segundos.

28 Desvio percentual médio (\%) dos 36 conjuntos de parâmetros testados considerando a solução da heurística RF33 limitada em 3600 segundos.

29 Desvio percentual médio (\%) das heurísticas construtivas por quantidade de máquinas e número de períodos. . . . . . . . . . . . p. 188

30 Tempo computacional médio (em segundos) das heurísticas construtivas por quantidade de máquinas e número de períodos. . . . . . . . p p. 188

31 Desvio percentual médio (\%) das quatro melhores abordagens de solução. p. 196

32 Tempo computacional médio das quatro melhores abordagens de solução. p. 197 


\section{Lista de Figuras}

1 Foto aérea de floresta plantada . . . . . . . . . . . p. 10

2 Árvores usadas em $95 \%$ da área plantadas. . . . . . . . . . . p. 11

3 Ilustração do problema abordado neste trabalho. . . . . . . . . p. p. 35

4 Ilustração do problema abordado em Santos e Almada-Lobo (2012) . p. p. 43

5 Planos de produção do modelo matemático original com divisão das gra-

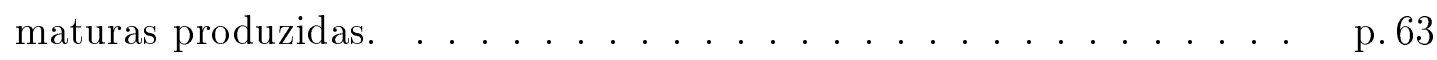

6 Planos de produção do modelo matemático com limitação na troca de

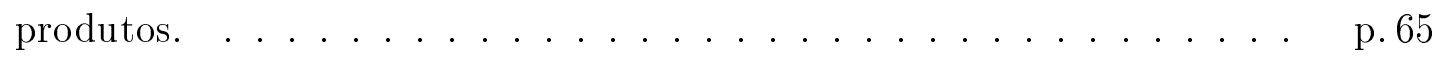

7 Planos de produção do modelo matemático com ciclos de produção. p.66

8 Gráfico de médias das parcelas de custo da função objetivo para exemplares com uma máquina de papel. . . . . . . . . . . p. 71

9 Gráfico de parcela de custos da função objetivo por instância com uma máquina de papel. ......................... p. 72

10 Gráfico de médias das parcelas de custo da função objetivo para exemplares com duas máquinas de papel. . . . . . . . . . . p. 72

11 Gráfico de parcela de custos da função objetivo por instância com duas máquinas de papel. . . . . . . . . . . . . . p. 73

12 Sequência de velocidades de trabalho do digestor - instância M1. . . . p p.74

13 Nível de estoque de celulose virgem - instância M1. . . . . . . . p. 75 
14 Sequência de produção ótima para a máquina de papel - instância M1. p. 76

15 Nível de estoque de licor negro fraco - instância M1. . . . . . . . p. 78

16 Nível de estoque de licor negro concentrado - instância M1. . . . . . p p. 79

17 Quantidade de vapor produzido - instância M1. . . . . . . . p. 80

18 Nível agregado de estoque e atraso de produtos finais - instância M1. p.81

19 Sequência de velocidades de trabalho do digestor - instância M2. . . . . p. 82

20 Nível de estoque de celulose virgem - instância M2. . . . . . . . p p 83

21 Sequência de produção ótima para a primeira máquina de papel - instância M2. . . . . . . . . . . . . . . . p. 84

22 Sequência de produção ótima para a segunda máquina de papel - instân-

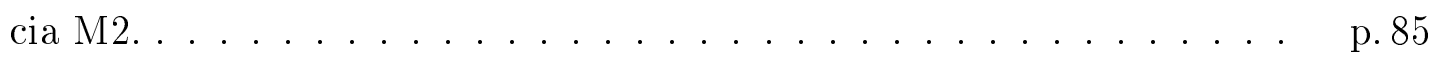

23 Nível de estoque de licor negro fraco - instância M2. . . . . . . p. 87

24 Nível de estoque de licor negro concentrado - instância M2. . . . . p. 88

25 Quantidade de vapor produzido - instância M2. . . . . . . . p. 89

26 Nível agregado de estoque e atraso de produtos finais - instância M2. p.90

27 Ciclos de produção 1 e $2 \ldots \ldots \ldots \ldots$ p. . . . . . . . . . . . . . . . .

28 Ciclos de produção com divisão das gramaturas por máquina de papel. p.103

29 Ilustração do particionamento 1 para as variáveis de decisão do digestor. p. 107

30 Ilustração do particionamento 2 para as variáveis de decisão do digestor. p. 107

31 Ilustração do particionamento 3 para as variáveis de decisão do digestor. p. 108

32 Ilustração do particionamento 4 para as variáveis de decisão do digestor. p. 109

33 Ilustração do particionamento 1 para as variáveis de decisão da máquina

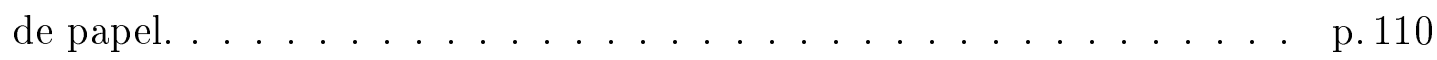

34 Ilustração do particionamento 2 para as variáveis de decisão da máquina

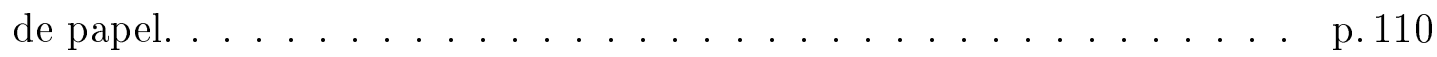

35 Ilustração do particionamento 3 das variáveis de decisão da máquina de

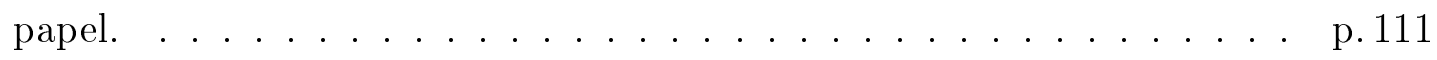


36 Ilustração do particionamento 4 para as variáveis de decisão da máquina de papel. ........................... 111

37 Ilustração do particionamento 5 para as variáveis de decisão da máquina de papel. . . . . . . . . . . . . . . . . p. 112

38 Ilustração do particionamento 6 para as variáveis de decisão da máquina

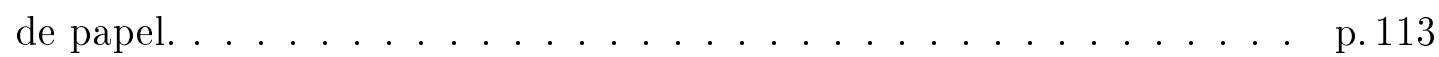

39 Ilustração do particionamento 7 para as variáveis de decisão da máquina de papel. .............................. 114

40 Ilustração do particionamento 8 para as variáveis de decisão da máquina de papel. . . . . . . . . . . . . . . . . . . p. . . . . . . . . . . . .

41 Particionamento por períodos das variáveis de controle das máquinas de

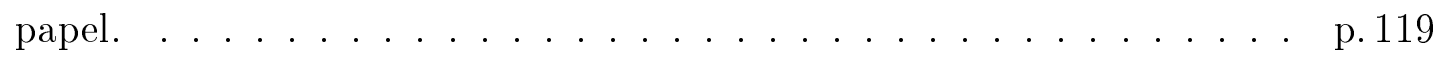

42 Particionamento por itens das variáveis de controle das máquinas de papel.p. 119

43 Particionamento em forma de cubo das variáveis de controle das máquinas de papel com sobreposição. . . . . . . . . . . . p. 120

44 Representação de indivíduo com três micro-períodos ativos por período. p. 131

45 Exemplo de mutação simples. . . . . . . . . . . . . . . p. 145

46 Exemplo de mutação de troca. . . . . . . . . . . . . . p. 145

47 Exemplo de mutação por inserção. . . . . . . . . . . . . . . . p. 146

48 Exemplo de mutação por rotação de cadeia com três passos. . . . . . . p. 146

49 Exemplo de mutação de sequência. . . . . . . . . . . . . . p. 147

50 Exemplo de mutação na quantidade de micro-períodos. . . . . . . . . p. 148

51 Exemplo do caso 1 da mutação por campanha. . . . . . . . . . . p. 148

52 Exemplo do caso 2 da mutação por campanha. . . . . . . . . . . . p. 149

53 Exemplo do caso 3 da mutação por campanha. . . . . . . . . . . p. 149

54 Exemplo do caso 4 da mutação por campanha. . . . . . . . . . . . p. 149

55 Exemplo do caso 5 da mutação por campanha. . . . . . . . . . p. 150

56 Exemplo do caso 6 da mutação por campanha. . . . . . . . . . p. 150 
57 Extrapolação dos tempos de preparação de máquina. . . . . . . . . p. 155

58 Extrapolação das perdas durante a preparação de máquina. . . . . . . . p. 155

59 Gráfico de curvas de desempenho do Cplex padrão contra o Cplex com parâmetros ajustados (somente soluções inteiras). . . . . . . . . p. 161

60 Gráfico de curva de desempenho do Cplex padrão contra o Cplex com parâmetros ajustados $(g a p) . \ldots \ldots \ldots$ p. . . . . . . . . . . . .

61 Gráfico de curvas de desempenho dos quatro melhores conjuntos de parâmetros da heurística gulosa. . . . . . . . . . . . . . . p. 164

62 Gráfico de curvas de desempenho dos quatro melhores conjuntos de parâmetros da heurística baseada em ciclos. . . . . . . . . . . . p. 166

63 Gráfico de curvas de desempenho dos sete melhores conjuntos de parâmetros da heurística relaxe-e-fixe. . . . . . . . . . . . . p. 169

64 Gráfico de curvas de desempenho (DM) dos cinco melhores conjuntos de parâmetros para a heurística FT-HCG. . . . . . . . . . . p. 173

65 Gráfico de curvas de desempenho dos cinco melhores conjuntos de parâmetros da heurística FT-HCBC. . . . . . . . . . . . . p. 175

66 Gráfico de curvas de desempenho dos cinco melhores conjuntos de parâmetros da heurística FFO-HCG. . . . . . . . . . . . . p. 177

67 Gráfico de curvas de desempenho dos cinco melhores conjuntos de parâmetros da heurística FFO-HCBC. . . . . . . . . . . p. 178

68 Gráfico de curvas de desempenho dos cinco melhores conjuntos de parâmetros da heurística FFO-RF21 com tempo limite para a heurística relaxe-e-fixe de 1800 segundos. . . . . . . . . . . . . . . p. 180

69 Gráfico de curvas de desempenho dos cinco melhores conjuntos de parâmetros da heurística FFO-RF21 com tempo limite para a heurística relaxe-e-fixe de 3600 segundos. . . . . . . . . . . . . . .

70 Gráfico de curvas de desempenho dos cinco melhores conjuntos de parâmetros da heurística FFO-RF33 com tempo limite para a heurística relaxe-e-fixe de 1800 segundos. . . . . . . . . . . . . . p. 183 
71 Gráfico de curvas de desempenho dos cinco melhores conjuntos de parâmetros da heurística FFO-RF33 com tempo limite para a heurística relaxe-e-fixe de 3600 segundos. . . . . . . . . . . . . . . p. 184

72 Gráfico de curvas de desempenho das cinco heurísticas construtivas. . . p. 187

73 Curva de desempenho dos métodos que utilizam o Cplex como processo de melhoria. . . . . . . . . . . . . . . . p. 190

74 Curva de desempenho das variantes do algoritmo genético. . . . . . . . p. 191

75 Curva de desempenho dos métodos compostos das heurísticas construtivas simples com melhoria por fixe-e-otimize. . . . . . . . . . . p. 192

76 Curva de desempenho dos métodos com solução inicial construídas pela heurística relaxe-e-fixe. . . . . . . . . . . . . . . . . p. 194

77 Curva de desempenho dos melhores métodos desenvolvidos. . . . . . . p. 195 


\section{Introdução}

A globalização ocorrida na economia mundial têm diminuído as distâncias e aumentado a competitividade entre os mercados dos países. Estas mudanças cada vez mais aceleradas têm aumentado a demanda por novas ferramentas de auxílio à tomada de decisões relacionadas ao planejamento e controle da produção (PCP). O PCP tem como objetivo coordenar os processos produtivos e administrar os recursos escassos de produção, a fim de garantir a continuidade deste processo produtivo e atender as demandas de produtos dos clientes. No contexto de otimização, as decisões do PCP devem ser tomadas de forma a tornar mais eficiente o processo produtivo de acordo com métricas de desempenho pré-estabelecidas. Estas métricas podem ser medidas em redução de custos, maximização de lucros, melhor uso de recursos restritos, entre outros fatores. Segundo Slack et al. (2009), o planejamento e controle da produção preocupa-se em gerenciar as atividades relacionadas a operação produtiva visando satisfazer a demanda dos clientes.

O PCP engloba decisões de curto, médio e longo prazo (KARIMI et al., 2003). No planejamento de longo prazo, ou planejamento de nível estratégico, o foco esta em antecipar as necessidades envolvidas, tais como decisões estratégicas na escolha de produtos, equipamentos e processos, localização de facilidades e planejamento de recursos. O planejamento de médio prazo, ou planejamento de nível tático, envolve decisões sobre as necessidades de matérias-primas (e outros recursos) e estabelece as quantidades a serem produzidas (tamanho dos lotes) em cada período do horizonte de planejamento. O objetivo é otimizar alguns critérios de desempenho, enquanto atende a demanda dos clientes e satisfaz as demais restrições do problema. O planejamento de curto prazo, ou planejamento de nível operacional, usualmente envolve decisões de semana-a-semana ou do dia-a-dia como, por exemplo, a programação e o sequenciamento da produção. Algumas destas decisões também são denominadas decisões de chão de fábrica por serem definidas pelo tomador 
de decisão no ambiente de produção.

Este trabalho aborda o problema de dimensionamento e sequenciamento de lotes aplicado à industria com processo integrado de produção de papel e celulose. Isto significa que o processo de produção da celulose e do papel são considerados de forma integrada, no qual a celulose produzida no primeiro estágio é consumida pelas máquinas de papel do segundo estágio. Este problema pode ser enquadrado como planejamento de médio a curto prazo, com mais ênfase no curto prazo, dado que são definidos planos de produção detalhados para cada unidade produtiva e os horizontes de planejamento considerados em geral não superam 30 dias. Além da unidade de produção de celulose, denominada digestor, e das máquinas produtoras de papel, o problema conta também com um tanque intermediário de estocagem de celulose e outros recursos relacionados à recuperação química de um resíduo de produção da celulose, denominado licor negro fraco.

O licor negro fraco tem alto poder de contaminação e, ao mesmo tempo, elevado potencial calorífero. Segundo Ince et al. (2011), a recuperação deste resíduo de produção é uma das maiores preocupações do ponto de vista ambiental e econômico neste setor. Os benefícios ambientais são alcançados evitando a contaminação do meio ambiente pelo descarte dos dejetos químicos usados no cozimento da madeira. Os principais problemas no descarte dos resíduos de produção da celulose são o alto teor de componentes orgânicos, a coloração marrom escuro, poluentes tóxicos, entre outros. Os benefícios comerciais relacionados a recuperação do licor negro são gerados pela produção de energia e vapor, e pela recuperação de reagente químicos usados no cozimento da madeira (reuso dos produtos químicos). Para cada tonelada de celulose produzida, são gerados cerca de 1,7 até 1,8 toneladas de licor negro concentrado, representando um potencial de produção de energia elétrica na casa de 250 a 500 MW (INCE et al., 2011).

A linha de recuperação química é constituída basicamente por tanques de estoque intermediários, evaporador e caldeira de recuperação química. Além disso, pode possuir turbinas de geração de energia elétrica, alimentadas pelo excedente de vapor não utilizado no processo produtivo. O vapor produzido na caldeira de recuperação química é utilizado para: aquecer a mistura de madeira e produtos químicos no digestor durante o processo de cozimento (quando a lignina é separada da celulose por meio de um processo termoquímico); auxiliar o processo de secagem das folhas de papel (associado a pressão e vácuo); aquecer o licor negro fraco que é concentrado no evaporador; entre outros.

A indústria de papel e celulose estudada neste trabalho tem importante relevância comercial. O setor industrial tem ganhado relevância nas últimas décadas devido ao 
aumento da demanda e produção, como apresentado no relatório de dados da Bracelpa (Associação Brasileira de Celulose e Papel) (BRACELPA, 2014a). O Brasil tem se destacado neste setor devido a altas taxas de produtividade das suas florestas plantadas, como apresentado neste mesmo relatório. Este destaque se deve a quatro combinações de fatores: clima e solo, pesquisa e desenvolvimento, setor privado organizado e mão de obra altamente qualificada. Segundo a associação IBA (Indústria Brasileira de Árvores), as exportações da indústria de árvores (celulose, papel e painéis de madeira) representam 3,99\% das exportações brasileiras de Janeiro a Maio de 2015 (IBA, 2015). Além disso, em 2012 o Brasil alcançou o posto de quarto maior produtor mundial de celulose e nono maior produtor de papel (BRACELPA, 2014a). Mais detalhes quanto ao panorama da indústria de papel e celulose no Brasil podem ser encontrados no Capítulo 2.

Além da relevância comercial, as dificuldades encontradas no planejamento e controle da produção deste setor industrial envolvem problemas com relevância científica e que necessitam de mais estudos. Como indicado em Santos e Almada-Lobo (2012), O PCP aplicado à indústria de papel e celulose é um problema de otimização de difícil solução. Os autores verificaram que o processo de produção integrado de papel e celulose é altamente complexo e dependente das tecnologias utilizadas. O processo de produção é composto por vários unidades produtivas interdependentes que podem ser divididas em quatro etapas: preparação da madeira, extração da celulose, recuperação química e produção do papel. Esta interdependência faz com que as tomadas de decisão integradas de produção se tornem vantajosas e, muitas vezes, necessárias para garantir a factibilidade do plano de produção. Ademais, os múltiplos recursos limitados, a imposição de produção contínua sem parada, a alta demanda por itens finais e o ajuste de velocidade de trabalho dos equipamentos, geram complexidade adicional ao problema.

Estas características associadas fazem com que a tomada de decisões de produção torne-se uma tarefa complexa, demandando ferramentas computacionais cada vez mais especializadas, que possam auxiliar o tomador de decisão. Alguns trabalhos da literatura consideram este tipo de planejamento integrado aplicado à indústria de papel e celulose. Santos e Almada-Lobo (2012) foram os primeiros a abordarem o PCP aplicado a produção integrada de papel e celulose como é abordado aqui. Neste trabalho foi feito um estudo de caso em uma empresa portuguesa do setor e foi desenvolvido um modelo matemático, que foi utilizado como ponto de partida para a extensão desenvolvida e apresentada nesta tese de doutorado. O processo de produção estudado têm as seguintes unidades produtivas: um digestor, uma máquina produtora de papel, uma linha de recuperação química e tanques de estoque intermediário de celulose virgem, celulose reciclada, licor negro fraco 
e licor negro concentrado.

O PCP aplicado à indústria integrada de papel e celulose também foi estudado em Figueira et al. (2013). Neste caso, os autores também estenderam o modelo matemático de Santos e Almada-Lobo (2012), para considerar ciclos de produção de papel com tamanho predefinido (em dias). Dentro de cada ciclo, a gramatura de início deve ser igual à gramatura de produção final e os atrasos de atendimento da demanda existentes no início do ciclo devem ser atendidos até o final do mesmo. Gramatura é uma medida que indica a densidade do papel dada pelo seu peso por metro quadrado. Em alguns casos, no entanto, o termo gramatura pode ser utilizado para definir todas as características do tipo de papel produzido, sendo elas a própria gramatura e a porcentagem de celulose reciclada incorporada. Com a obrigação de atendimento das demandas atrasadas, os autores apresentaram abordagens para tentar reduzir os atrasos na entrega, comumente verificados em empresas deste setor produtivo. Mais detalhes sobre trabalhos que abordam problemas relacionados à indústria de papel e celulose são apresentados na Seção 2.5.

Conforme mencionado, os trabalhos de Santos e Almada-Lobo (2012) e Figueira et al. (2013) também abordaram o problema tratado nesta tese de doutorado, no entanto, algumas lacunas permaneceram abertas. Em visitas técnicas realizadas a empresas brasileiras do setor, foi verificado que existem plantas produtivas que contam com estruturas distintas das estudadas anteriormente como, por exemplo, múltiplas máquinas produtoras de papel. Isto motivou a pesquisa por extensões dos modelos matemáticos existentes para considerar essas situações.

Como ferramentas de solução comerciais não foram capazes de obter soluções de alta qualidade para exemplares de teste realistas de grande porte, fez-se necessário o desenvolvimento de outras abordagens de solução (SANTOS; ALMADA-LOBO, 2012; FIGUEIRA et al., 2013). Em Santos e Almada-Lobo (2012) foi desenvolvido um método de solução baseado em relaxe-e-fixe (relax-and-fix) com melhoria via fixe-e-otimize (fix-and-optimize). No entanto, como o foco do artigo foi a modelagem matemática, testes exaustivos não foram realizados para verificar a real eficiência do método. Estes tipos de abordagens foram retomados nesta tese de doutorado, onde foram testadas e comparadas aos demais métodos desenvolvidos. Além disso, em Figueira et al. (2013) foi desenvolvido uma meta-heurística do tipo VNS (Variable neighborhood search), para resolver o problema abordado. Furlan et al. (2015) reportam um algoritmo genético híbrido desenvolvido, uma contribuição com resultados iniciais desta tese, para um problema correlato ao estudado aqui, com algumas características distintas. Em Furlan et al. (2015) o VNS de Figueira et al. (2013) foi 
adaptada para o problema estudado e foi comparado ao algoritmo genético híbrido desenvolvido. Os resultados indicaram desempenho comparável entre o VNS e o algoritmo genético.

Tendo em vista os desafios e questões abertas sobre o problema de planejamento e sequenciamento da produção no setor de celulose e papel, os objetivos desta tese são:

- Estudar o problema de planejamento, programação e controle da produção aplicado à indústria integrada de papel e celulose;

- Propor modelos matemáticos que possam descrever apropriadamente as características das plantas produtivas estudadas;

- Propor métodos de solução efetivos para construir planos de produção factíveis e de qualidade razoável para exemplares de tamanho realista do problema estudado.

Para atingir esses objetivos,as seguintes tarefas foram realizadas:

- Modelos matemáticos

Desenvolver modelos matemáticos para gerar os planos de produção para o problema de dimensionamento e sequenciamento de lotes da indústria integrada de papel e celulose, considerando múltiplas máquinas de papel, um digestor e uma linha de recuperação química. Conforme mencionado, estes modelos são extensões do modelo matemático de Santos e Almada-Lobo (2012), com modificações feitas de acordo com características produtivas verificadas durante visitas técnicas feitas a empresas brasileiras do setor. Além disso, foram desenvolvidos conjuntos de restrições com base em práticas industriais como, por exemplo, a divisão prévia das gramaturas por máquinas de papel e a limitação na troca entre gramaturas muito distintas. Testes computacionais foram feitos a fim de analisar os impactos de tais práticas. Mais detalhes sobre os modelos matemáticos desenvolvidos, bem como os modelos matemático correlatos, podem ser encontrados no Capítulo 3. Alguns detalhes das visitas técnicas feitas são apresentados na Seção 2.4 e as características do problema abordado são detalhadas na Seção 2.6.

- Abordagens de solução

Desenvolver métodos variados para resolver os modelos matemáticos:

- Heurísticas construtivas 
Foram desenvolvidas quatro heurísticas construtivas, sendo elas: uma heurística construtiva gulosa, uma heurística construtiva baseada em arredondamento, uma heurística construtiva baseada em ciclos predefinidos de produção e uma heurística relaxe-e-fixe com diferentes tipos de particionamento das variáveis inteiras.

\section{- Heurísticas de melhoria}

Duas variações da heurística fixe-e-otimize foram estudadas e implementadas para abordar o problema tratado, que foram combinadas com as heurísticas construtivas. A primeira variação é uma implementação tradicional do método, enquanto a segunda foi proposta com o intuito de obter vantagens da estrutura multi-nível do problema por meio de mudanças na função objetivo durante o processo de solução. Este procedimento tenta evitar mínimos locais ocasionados pela estrutura do processo e pela falta de custos associados ao primeiro nível produtivo na função objetivo. Mais detalhes sobre as heurísticas construtivas e de melhoria são apresentados no Capítulo 4.

\section{- Algoritmo genético}

Foram desenvolvidos um algoritmo genético híbrido e sua combinação com uma das heurísticas construtivas. Resultados iniciais do algoritmo genético foram reportados em Furlan et al. (2015), uma publicação resultante desta tese. Um exemplo de mudança ocorre em não considerar a mistura de celulose reciclada na produção das gramaturas de papel, como apresentado em Santos e Almada-Lobo (2012). Como todas as modificações foram feitas nas restrições e variáveis lineares do problema, não foram necessárias alterações na abordagem de solução (apenas no sub-problema linear resultante). Além da melhor variante apresentada no artigo, foi testada também uma combinação desta com soluções iniciais construídas pela heurística construtiva com ciclos de produção predefinidos. Mais detalhes quanto ao algoritmo genético proposto e as modificações feitas com relação ao método original podem ser vistas no Capítulo 5.

- A ferramenta de solução LP/MIP comercial Cplex 12.6

Foram testadas algumas variações de aplicação na ferramenta Cplex ao problema abordado. Como o método branch-and-cut do Cplex, em sua parametrização padrão, não foi capaz de resolver de forma eficiente alguns exemplares de teste gerados, foram feitos testes com parâmetros ajustados com um subconjunto de exemplares e uma combinação entre as heurísticas construtivas 
mais simples com a ferramenta de solução. Desta forma, o Cplex se tornou responsável por tentar melhorar as soluções geradas pela heurística construtiva e, de alguma forma, tomar proveito desta inicialização com algum conhecimento do problema.

- Geração de dados

Propor um gerador e gerar diversos exemplares de teste para o problema (mais de 500) de forma aleatória, baseado em situações realistas (dados). Os exemplares têm tamanho de horizonte de planejamento de 7, 15 e 30 dias, quantidade de gramaturas distintas de 8, 16 e 24, e 1 ou 2 máquinas produtoras de papel. Adicionalmente, foram gerados exemplares com 3 ou 4 micro-períodos por período e 15 diferentes cargas de trabalho nos distintos recursos existentes. Mais detalhes sobre os exemplares gerados e o gerador utilizado são apresentados na Seção 6.1.

- Análise computacional e parametrização

Realizar análises computacionais com uso de gráficos de curvas de desempenho (DOLAN; MORÉ, 2002), testes de hipótese nula (Wilcoxon pareado), além do uso de desvios percentuais e tempos computacionais médios. A partir destas métricas, foram testadas variadas combinações entre as heurísticas construtivas, heurísticas de melhoria e demais métodos desenvolvidos. Um processo de parametrização dos métodos foi feito para testar diversas combinações de parâmetros para cada abordagem de solução desenvolvida. Estes resultados são apresentados antes da comparação entre as abordagens de solução, nos quais o procedimento de parametrização varia de acordo com o método que foi refinado. Ademais, as comparações finais entre os métodos foram agrupadas por tipo de abordagem para facilitar o entendimento dos resultados computacionais e evitar que a análise dos resultados se tornasse confusa devido ao elevado número de combinações testadas.

Esta tese de doutorado é justificada pelas dificuldades científicas e práticas encontradas no planejamento e controle da produção do setor produtor de papel e celulose, no qual a tarefa de construir planos de produção factíveis e de qualidade razoável pode ser complexa. O estudo também se justifica pela pouca literatura encontrada sobre trabalhos que estudem o problema acoplado de dimensionamento e sequenciamento de lotes de produção em indústria integrada de papel e celulose, da forma como é estudado aqui. Por fim, os estudos neste setor produtivo se justificam pela sua importância econômica no contexto industrial brasileiro, que tem ganhado importância nas exportações nacionais. 
Segundo a tipologia de Bertrand e Fransoo (2002), a metodologia de pesquisa utilizada aqui tem como base modelos quantitativos, sendo parte axiomática e parte empírica. Esta pesquisa caracteriza-se como axiomática por tentar descrever por meio de modelos matemáticos as estruturas produtivas verificadas em empresas brasileiras visitadas. Além disso, se caracteriza como normativa (ou prescritiva) por tentar gerar estratégias de solução baseadas em variadas abordagens de solução. Por outro lado, esta pesquisa se caracteriza como empírica normativa por utilizar conjuntos de exemplares de teste para verificar empiricamente a adequação dos modelos matemáticos e das abordagens de solução para tratar o problema observado.

As principais contribuições desta tese são: a extensão de um modelo matemático da literatura para considerar estruturas produtivas com múltiplas máquinas produtoras de papel, o desenvolvimento de abordagens de solução efetivas para o problema estudado e que podem ser adaptadas para problemas correlatos, a extensão de um gerador de exemplos de teste com as características das empresas brasileiras visitadas e a combinação de estratégias de solução híbridas entre heurísticas, meta-heurísticas e métodos de solução exata.

O restante deste trabalho está organizado da seguinte forma. O Capítulo 2 apresenta uma breve introdução do contexto econômico e das características produtivas do setor de papel e celulose, seguido de uma revisão da literatura de problemas abordados neste setor industrial. O capítulo termina com a descrição detalhada do problema aqui abordado. O Capítulo 3 apresenta uma breve revisão sobre modelagem matemática, seguida de uma revisão de modelos matemáticos aplicados a problemas correlatos. Em seguida, é feita na Seção 3.4 a apresentação do modelo matemático desenvolvido e das restrições construídas a partir de práticas industriais verificadas. Resultados computacionais preliminares para verificar o impacto destas restrições são apresentados na Seção 3.5.5 deste mesmo capítulo. As heurísticas construtivas e de melhoria desenvolvidas são descritas no Capítulo 4, seguidas da descrição do algoritmo genético híbrido desenvolvido e apresentado no Capítulo 5. O Capítulo 6 contém os resultados dos testes computacionais de todas as abordagens de solução propostas nesta tese, na forma de tabelas, gráficos e análises estatísticas de teste de hipótese nula. Os resultados computacionais foram divididos em três partes. Na Seção 6.3 são apresentados os resultados referentes ao ajuste de parâmetros de cada método desenvolvido e das combinações testadas. Na Seção 6.4 são comparados primeiramente os resultados de forma agrupada e, em seguida, são comparados apenas os melhores métodos de cada uma das comparações por grupos. Finalmente, as conclusões desta tese e algumas perspectivas de trabalhos futuros são descritas no Capítulo 7. 


\section{Indústria de papel e celulose}

Neste capítulo apresentamos brevemente o setor industrial de celulose e papel do ponto de vista econômico e do processo produtivo. Na Seção 2.1 apresentamos dados de relatórios financeiros da associação brasileira de celulose e papel (Bracelpa) sobre a indústria nacional e sua relevância no contexto mundial. A Seção 2.2 apresenta alguns dados sobre a área florestal e produtividade das florestas brasileiras, além de definir alguns tipos de celulose e suas aplicações. Os meios produtivos de celulose e de papel são definidos na Seção 2.3. Estudos da literatura que abordam problemas deste setor produtivo são apresentados na Seção 2.5. Na Seção 2.4 descrevemos o processo produtivo das empresas visitadas durante este projeto de doutorado. Finalmente, na Seção 2.6, apresentamos as características do problema abordado neste projeto de doutorado.

\subsection{Panorama brasileiro e mundial do setor}

O Brasil ganhou relevância neste setor produtivo de papel e celulose desde seu ingresso na década de 1970. Segundo o relatório anual de dados do setor, compilado pela Bracelpa (BRACELPA, 2014a), a produção brasileira de celulose e papel tiveram crescimento médio anual de 7,1\% e 5,4\%, respectivamente, entre os anos de 1970 e 2013. No ano de 2012, o Brasil consolidou-se como o quarto maior produtor mundial de celulose, com produção próxima à 14000 toneladas, e nono maior produtor mundial de papel, com produção superior à 10000 toneladas. Percentualmente, o Brasil é responsável pela produção de 8,4\% da celulose e 2,6\% do papel demandado mundialmente (BRACELPA, 2014a).

Segundo relatório da Bracelpa, apresentado em março de 2014 (BRACELPA, 2014b), o setor de celulose foi responsável por 3,46\% das exportações e 0,80\% das importações da indústria brasileira no ano de 2013. As exportações apresentaram crescimento de 11,3\% 
e as importações tiveram leve redução de 1,40\%, nos meses iniciais de 2014, quando comparado com os resultados de 2013. Os maiores consumidores da celulose brasileira são China, Europa e América do Norte, enquanto que a maior parte das exportações de papel se concentra em atender a demanda de mercados da América latina.

\section{2 Área florestal, produtividade e tipos de celulose}

As florestas plantadas (Figura 1) para o abastecimento de fabricas de celulose e papel se concentra majoritariamente nas regiões Sudeste e Sul do Brasil, além dos estados de Mato Grosso do Sul e Bahia. A Bracelpa conta atualmente com 220 empresas associadas que abrangem 540 municípios em 18 estados. A área de floresta plantada para fins industriais destas empresas chega a 2,2 milhões de hectares (ha) e 128 mil empregos diretos foram gerados.

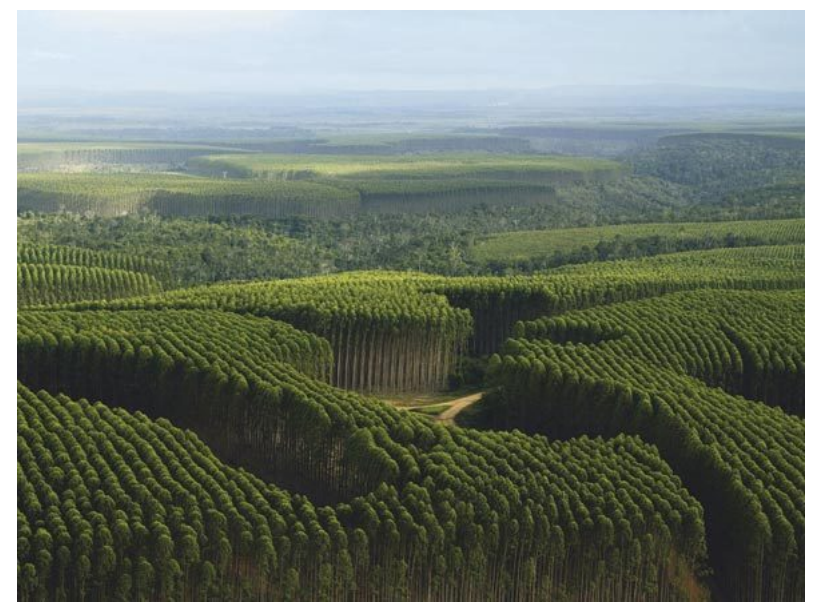

Figura 1: Foto aérea de floresta plantada. Fonte: http://www.ciflorestas.com.br/conteudo.php?id=5783

Estas florestas plantadas são compostas em sua maioria (95\% do total de área plantada) por dois tipos de madeiras e dão origem a tipos diferentes de celulose. Estas celuloses são denominadas celulose de fibra curta e celulose de fibra longa.

Celulose de fibra curta é obtida por meio do processamento de eucaliptos (Figura 2a), árvores do gênero Eucalyptus que conta com mais de 700 espécies. Esta espécie arbórea tem grande produtividade no Brasil e, associado a melhorias genéticas e de manejo, tem atingido altos níveis de produtividade. Segundo a Bracelpa (2014a), no ano de 2011 a produtividade média de madeira do eucalipto chegou a $44 \mathrm{~m}^{3} / \mathrm{ha} / \mathrm{ano}$, um aumento de $83 \%$ quando comparado com a produção média em 1980, que era de $24 \mathrm{~m}^{3} / \mathrm{ha} /$ ano. Este valor também é muito superior aos encontrados em outros grandes produtores, como os 
países da Escandinávia e da Península Ibérica. O Eucalipto tem produção média de 12 $\mathrm{m}^{3} / \mathrm{ha}$ /ano e $10 \mathrm{~m}^{3} / \mathrm{ha} /$ ano em Portugal e Espanha, respectivamente. Na Escandinávia, devido ao clima mais frio é utilizado a Bétula para a obtenção de celulose de fibras curtas e sua produtividade fica no intervalo de 4 até $6 \mathrm{~m}^{3} / \mathrm{ha} / \mathrm{ano}$. Enquanto no Brasil são necessários 100 mil hectares para a produção de 1 milhão de toneladas ano, na Península Ibérica são precisos 3 vezes mais área plantada e nos países da Escandinávia essa área chega a 7,2 vezes. Celuloses de fibras curtas são ideais para a produção de papéis para impressão e escrita e de fins sanitários (papel higiênico, toalhas de papel, guardanapos). Fibras do eucalipto também são utilizadas para a produção de celuloses especiais, como as utilizadas na produção de cápsulas para produtos farmacêuticos, resinas e cosméticos.

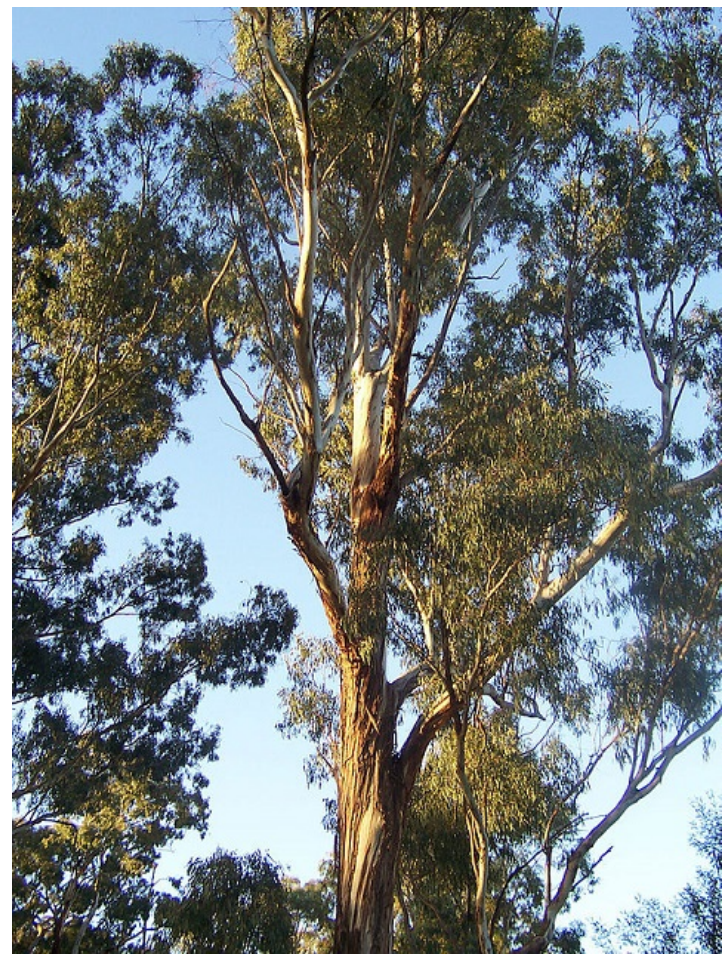

(a) Árvore de Eucalipto

Fonte: http://pt.wikipedia.org/wiki/Eucalipto

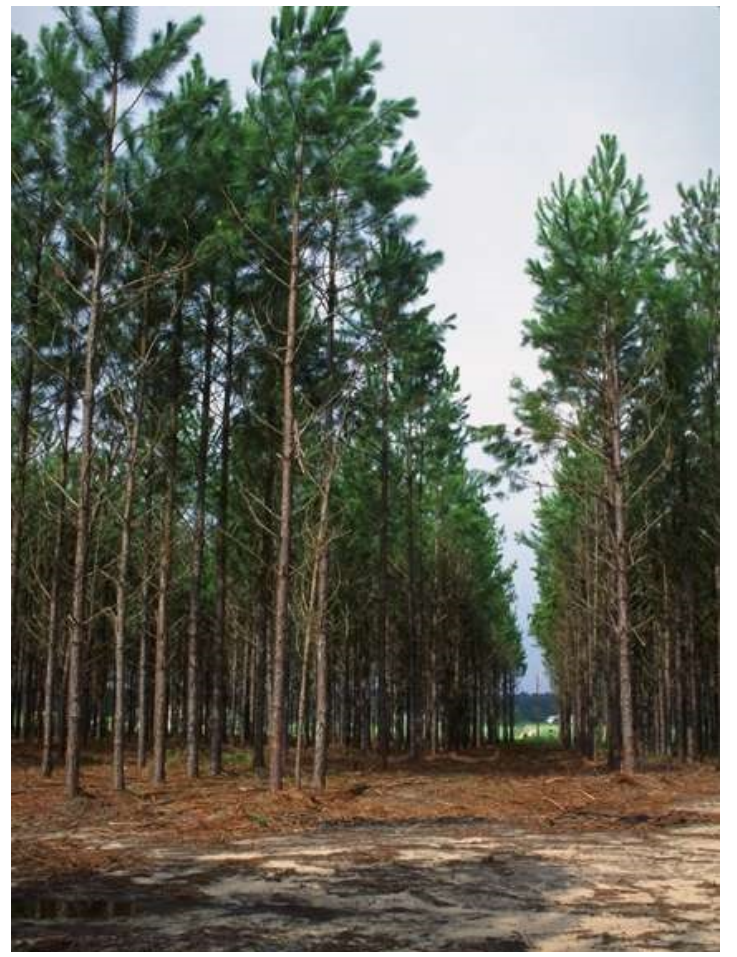

(b) Árvore de Pinus.

Fonte: http://pt.wikipedia.org/wiki/Pinus_ elliottii

Figura 2: Árvores usadas em 95\% da área plantadas.

Celulose de fibra longa têm sua origem de árvores ditas de madeira mole. A principal espécie utilizada na produção de celulose de fibra longa é o Pinus Elliottii (Figura 2b), árvore do gênero pinus (pinheiros). Estas são plantas de rápido crescimento e resistentes ao frio, dada sua origem em clima temperado. Apesar disso, têm boa adaptação em regiões tropicais e atualmente também apresentam alta produtividade em solo brasileiro. Segundo a Bracelpa (2014a), a produtividade média do pinus no Brasil atingiu 38 $\mathrm{m}^{3} /$ ha/ano em 2011, o dobro do valor verificado em 1980. Neste caso, o Brasil é novamente o país com maior rendimento mundial, seguido por Chile $\left(22 \mathrm{~m}^{3} / \mathrm{ha} / \mathrm{ano}\right)$, Nova 
Zelândia $\left(22 \mathrm{~m}^{3} / \mathrm{ha} / \mathrm{ano}\right)$ e Estados Unidos (10 $\left.\mathrm{m}^{3} / \mathrm{ha} / \mathrm{ano}\right)$. Celuloses de fibras longas são utilizadas majoritariamente em papéis de alta resistência, como papéis para embalagens, camadas internas de papel cartão e papel de jornal. Dentre os papéis de embalagem, podemos destacar o papel do tipo kraft, também conhecido como papel pardo, produzidos na empresa portuguesa estudada por Santos e Almada-Lobo (2012).

\subsection{Processos produtivos de celulose e papel}

Neste setor produtivo, existem empresas que produzem e vendem apenas celulose, empresas que produzem e vendem apenas papel e compram a celulose, e empresas integradas que produzem e vendem ambos. Apresentamos na Seção 2.3.1 o processo produtivo da celulose, associado ao problema de recuperação de resíduos e na Seção 2.3.2, o processo produtivo de papel, considerando também o processo produtivo integrado.

\subsubsection{Produção de celulose e recuperação de resíduos}

Inúmeros tipos de meios produtivos podem ser encontrados na produção de celulose, variando a tecnologia empregada e as etapas do processo de produção, de acordo com o tipo de produto demandado, como averiguado nas visitas técnicas feitas. Foram descritas como características que definem parte do processo produtivo e a qualidade dos produtos finais: o nível de resíduos químicos na composição da pasta de celulose (pureza), o nível de alvura da pasta de celulose (branqueamento), a consistência e a resistência.

Segundo a Bracelpa e verificações feitas durante as visitas técnicas, as seguintes etapas são comumente encontradas no processo produtivo da celulose:

- Preparação da madeira: A madeira colhida nas florestas plantadas são descascadas e picadas em cavacos de poucos centímetros (pedaços pequenos de madeira);

- Polpação: Existem variados processos para separar a celulose do restante dos componentes da madeira. Atualmente, o mais utilizado em empresas de grande porte é um processo termo-químico realizado utilizando um digestor. O digestor é o equipamento responsável pelo cozimento da madeira e separação da celulose dos demais componentes da madeira, como a lignina. Os cavacos são submetidos ao processo de cozimento com a utilização de produtos químicos como, por exemplo, a mistura de Hidróxido de Sódio e Sulfeto de Sódio, conhecida por licor branco. Esta mistura é utilizada para quebrar a ligação entre a celulose e a lignina presentes na madeira; 
- Lavagem e Branqueamento: Dependendo do tipo de celulose demandada, a polpa pode passar por processos de lavagem, depuração e branqueamento. Estes processos demandam reagentes químicos, como alvejantes usados no branqueamento, por exemplo. A quantidade de etapas e o nível de depuração dos processos de limpeza dependem da qualidade do produto demandado. Por exemplo, o limite no nível de reagentes químicos presente em celulose utilizada para a produção de papel para embalagens é superior ao permitido para celuloses que são utilizadas em produtos alimentícios, como o invólucro de salsichas produzido na empresa brasileira produtora de celulose solúvel especial visitada;

- Secagem: A pasta de celulose líquida, constituída em sua maior parte por água, é espalhada entre duas telas de tecido absorvente denominadas telas formadoras. Estas telas dão forma a placa de celulose e removem a maior parte dos líquidos da pasta, pois são associadas a um sistema de remoção de água por vácuo. A placa, com nível menor de água, passa por um sistema com grandes rolos de prensagem e cilindros aquecidos por vapor, responsáveis pela remoção de outra parcela da água. A celulose resultante, conserva ainda um nível mínimo de água, de acordo com o tipo de produto demandado;

- Bobinadora: A bobinadora é um sistema associado as secadoras que produz grandes bobinas contínuas à partir da placa contínua de celulose produzida no processo de secagem. Estas bobinas são denominadas jumbos. Os jumbos têm tamanho limitado pelas capacidades produtivas da linha como, por exemplo, a capacidade de carga da ponte rolante que transfere o jumbo da bobinadeira para a linha de corte. Em uma das empresas brasileiras visitadas, por exemplo, os jumbos eram produzidos com cerca de 20 toneladas cada;

- Cortadora: Os jumbos passam por processo de corte, que produz bobinas de menor largura e comprimento. A largura das bobinas é definida de acordo com as especificações demandadas pelos clientes, no caso de itens finais, e pelas características das cortadoras de placas retangulares, no caso da celulose vendida em fardos;

- Empacotamento: O produto final é empacotado de duas maneiras. As bobinas são revestidas por papel pardo e as placas são prensadas em fardos e empacotadas também com papel pardo. Estes produtos são estocados até serem enviados para estoques externos ou diretamente para os clientes.

A produção de celulose no digestor tem como objetivo remover componentes orgâni- 
cos que se encontram ligados a celulose, como a lignina, por exemplo. Estes componentes são removidos na forma de um resíduo químico denominado licor negro fraco. O licor negro fraco tem alta concentração de compostos químicos inorgânicos utilizados no cozimento da madeira e, por este motivo, pode ser altamente contaminante para o meio ambiente se for descartado de forma inadequada. O tratamento deste resíduo produtivo é imprescindível para a redução dos impactos ambientais, além de possibilitar o reuso dos componentes químicos no processo de cozimento (redução de gastos com insumos). Existe ainda grande porcentagem de matéria orgânica nestes resíduos, que é reaproveitada durante a recuperação química devido ao seu alto valor energético (INCE et al., 2011).

Durante as visitas técnicas foram verificados dois tipos distintos de digestores. O primeiro tipo de digestor é denominado digestor contínuo pela forma como produz a celulose. O processo de produção da celulose se dá de forma contínua e ininterrupta, ou seja, o digestor tem um fluxo de produção e consumo de matéria prima. Neste caso a taxa de produção é alterada pela velocidade de funcionamento mecânico do equipamento e pelos componentes químicos utilizados no cozimento. O segundo tipo de digestor é nomeado digestor por batelada. O digestor por batelada, como o nome sugere, produz celulose em quantidades pré-definidas. Tanto os produtos químicos como os cavacos de madeira são colocados dentro do equipamento, que é fechado e fica durante certo tempo fazendo o cozimento da madeira. Após o período de cozimento, o digestor é esvaziado. Uma nova batelada pode então ser feita assim que o equipamento for preparado para a produção. Como a máquina de secagem (ou a máquina produtora de papel, no caso de processo integrado) têm consumo contínuo de celulose, este segundo tipo de digestor foi observado na prática apenas em conjuntos de digestores. Desta forma, o tomador de decisões pode sequenciar os digestores para obter produção de celulose mais próxima ao processo contínuo de consumo.

O processo de recuperação de resíduos conta com evaporadores, tanques de estoque intermediário, caldeiras de recuperação e turbinas que transformam vapor de alta pressão em energia elétrica. Nos evaporadores o líquido é concentrado pelo aquecimento do licor e remoção da água excedente. Isto é feito utilizando vapor que aquece o líquido em uma serpentina sob pressão controlada. O líquido concentrado é estocado e posteriormente queimado na caldeira de recuperação. Dois produtos são gerados a partir da queima do licor negro concentrado: vapor e resíduo inorgânico sólido. O vapor é enviado para suprir a demanda da empresa em processos como o cozimento, a secagem da folha de celulose e a evaporação do licor negro fraco. O excedente de vapor pode ser enviado às turbinas para a geração de energia elétrica, que pode ser consumida na própria empresa ou 
revendida a concessionária de energia local. O resíduo inorgânico passa por um processo de caustificação que tem o objetivo de retirar deste resíduo os componentes utilizados no processo de cozimento, mais precisamente o hidróxido de sódio (soda cáustica). A caustificação é um processo químico no qual se utiliza cal virgem para remover o hidróxido de sódio. Desta forma, o hidróxido de sódio pode ser reutilizado no processo de cozimento.

\subsubsection{Produção de papel}

O papel tem ampla gama de usos, sendo um produto amplamente consumido no cotidiano. Segundo a Bracelpa, ele tem importância em seguimentos como educação, veículos de comunicação escrita, armazenamento de produtos, limpeza e higiene. Pode compor livros, jornais, revistas, documentos, embalagens, entre outros produtos. A demanda por papel do mercado nacional e internacional tem crescido com o passar dos anos (BRACELPA, 2014b). Para suprir essa necessidade, a indústria tem investido em metodologias e formas para tornar o ambiente produtivo mais eficiente, reduzindo os impactos ambientais. Segundo a Bracelpa, no Brasil o papel produzido tem origem, quase que em sua totalidade, em madeira reflorestada.

A matéria prima básica da indústria produtora de papel é a celulose, obtida principalmente pelo processo de beneficiamento da madeira e, também, de aparas de papel geradas durante o processo industrial. A celulose utilizada para a produção pode ser adquirida no mercado, de empresas produtoras, ou produzida em processo integrado de celulose e papel. Segundo a Bracelpa e algumas características verificadas durante as visitas técnicas feitas, as etapas necessárias para a produção do papel são os seguintes:

- Celulose: A celulose pode ser comprada no mercado ou produzida em linha de produção integrada. A celulose comprada passa por processo de reidratação, feita em um equipamento conhecido como desagregador, pulper ou ainda hidrapulper. No caso de fábricas integradas, a celulose é enviada diretamente dos tanques de armazenamento da polpa de celulose ao processo de lavagem e tingimento;

- Hidrapulper (despolpador): Incorpora água a celulose que se encontra em estado sólido, retornando a forma original de pasta. A celulose deve encontrar-se neste estado para incorporar tintas, colas e outros componentes que darão características desejáveis ao produto, de acordo com a demanda dos clientes;

- Lavagem e tingimento: A pasta de celulose pode receber tintas, colas e outros produtos para adquirir características desejáveis no produto final. Por exemplo, a 
adição de cola reduz o poder de absorção do papel e aumenta sua resistência, o que é desejável para papéis de impressão, mas pode ser problemático em papéis absorventes como os de higiene e limpeza, por exemplo;

- Processos adicionais: A pasta de celulose pode também passar por processos que quebram as fibras de celulose para que o papel produzido possa ganhar maior aderência e uniformidade;

- Máquina de papel: A máquina de papel é semelhante a máquina secadora do processo de produção da celulose. A pasta de celulose com aditivos é depositada entre as telas de tecido formador, para ser prensada e aquecida para remover o excesso de água. Neste ponto, pode haver também a incorporação de celulose reciclada, como observado por Santos e Almada-Lobo (2012) em uma empresa portuguesa produtora de papel pardo para embalagem. A diferença com relação a secadora ocorre na possibilidade de produção de variadas gramaturas. Enquanto a secadora produz bobinas de celulose de espessura constante, a máquina de papel gera um conjunto de possíveis gramaturas para atender a demanda dos clientes. Este ajuste é feito com a máquina em movimento, processo que ocasiona perdas de matéria-prima e tempo;

- Bobinadora e cortadora: O processo de produção de bobinas jumbos e de corte em produtos finais é idêntico ao apresentado nas etapas produtivas da celulose.

\subsection{Visitas técnicas em empresas produtoras de papel e celulose}

Nesta seção apresentamos um breve resumo sobre as visitas técnicas realizadas durante o doutorado. Na Seção 2.4.1 é apresentado o ambiente produtivo de uma empresa produtora de celuloses especiais situada no estado da Bahia. A Seção 2.4.2 apresenta as características de uma empresa de grande porte instalada no interior do estado de São Paulo que produz papel e celulose branqueados. Na Seção 2.4.3 apresentamos as características de uma empresa portuguesa deste setor, sendo esta a mesma planta estudada em Santos e Almada-Lobo (2012). 


\subsubsection{Empresa produtora de celulose solúvel especial situada na Bahia}

Em Dezembro de 2011 foi feita uma visita técnica a uma empresa situada no estado da Bahia que produz celuloses especiais. Esta empresa possui um processo adicional na linha de produção, quando comparado com o processo produtivo apresentado na Seção 2.3.1. Este processo adicional é necessário para obtenção de celulose com maior pureza.

O problema de planejamento da produção de celulose solúvel especial se distingue em alguns processos da produção de celulose para papel, de acordo com a exigência de pureza demandada pelos clientes e suas aplicações finais. Como verificado durante a visita, celulose solúvel especial pode ser utilizada para produção de viscose para tecidos, acetato para resinas, celulose microcristalina para aplicações em produtos farmacêuticos, entre outros.

Cada tipo de aplicação demanda que a celulose seja produzida com certas características, como pureza, alvura, consistência e resistência. A empresa visitada possui duas linhas de produção que se integram no consumo de matéria prima (madeira), na recuperação de resíduos, na obtenção de água e no tratamento de efluentes. As duas linhas se distinguem em algumas partes do processo produtivo e nos produtos finais gerados. A primeira linha produz somente celulose utilizada na produção de viscose, que exige um nível menor de pureza e são nomeadas Rayon-grades. A segunda linha, mais moderna, pode produzir tanto Rayon-grades como Specialty-grades, um tipo de celulose com maior grau de pureza que é utilizado em aplicações de maior exigência, como cosméticos e produtos farmacêuticos.

Apresentamos à seguir as características das duas linhas produtivas e da planta de recuperação química.

- Linha de produção 1

O cozimento da madeira na Linha 1 é realizado utilizando um conjunto de três digestores dedicados que trabalham por bateladas. Após o cozimento, a celulose passa por processos de lavagem e processos de remoção de lignina por adição de oxigênio. Neste ponto, a pasta é armazenada em um tanque intermediário de estocagem de celulose marrom. A celulose marrom é submetida ao processo de branqueamento e armazenada em um tanque de estocagem de celulose branqueada.

A celulose branqueada é enviada à máquina de secagem, que é similar a uma máquina produtora de papel, diferindo apenas por não ter variação na gramatura do produto. 
Após a secagem, a celulose é enrolada em grandes bobinas denominadas jumbos. Os jumbos são posteriormente cortados em placas ou bobinas menores, de acordo com a carteira de pedidos. A sequência de processos desta linha de produção não tem diferenças em etapas produtivos com o que foi apresentado na Seção 2.3.1. Neste caso, as variações ocorrem apenas na intensidade de remoção de lignina e outros resíduos, para a obtenção de produtos finais de maior pureza.

- Linha de produção 2

A Linha de produção 2 tem oito digestores dedicados que também trabalham por bateladas. Após o cozimento, a pasta produzida é armazenada em tanques intermediários. Posteriormente, esta celulose passa por processos de limpeza e lavagem, para eliminar as impurezas e resíduos. No caso da celulose especial, existe o acréscimo de um processo chamado Cold Caustic Extraction (CCE) para eliminar uma parte da hemi-celulose, tipo de celulose indesejada, e obter um teor de pureza ainda maior. A celulose purificada é armazenada em um tanque intermediário, para posterior processo de branqueamento. A celulose branqueada é armazenada em tanque e enviada para a máquina de secagem. À partir deste ponto, o processo é similar ao da Linha de produção 1 .

- Planta de Recuperação química

O setor de recuperação química é similar ao apresentado em Santos e AlmadaLobo (2012), sendo composto por tanques de estoque intermediário, evaporador e caldeira de recuperação. Na empresa visitada, a planta de recuperação química é compartilhada pelos resíduos dos digestores das duas linhas produtivas. Cabe ressaltar que este setor tem grande importância no planejamento da produção, pois pode se tornar um gargalo produtivo para as duas linhas. Além disso, o volume de resíduos produzidos tende a ser maior, dada a necessidade de maior pureza nos produtos finais.

- Informações adicionais

O rendimento de celulose com relação ao volume de madeira utilizada é de cerca de $35 \%$ a 40\% no processo de produção de celulose solúvel especial, por conta da eliminação de grande parte da hemi-celulose. Segundo Schumacher e Sathaye (1999), em um processo de produção de celulose para papel de alta qualidade a produtividade é de cerca de $40 \%$ a $60 \%$ do peso da madeira seca. Além do teor pureza, existe uma série de outros parâmetros que definem o tipo de produto final obtido, sendo os 
mais relevantes viscosidade e alvura. Ressalta-se ainda que quanto maior a pureza do produto, menor a resistência da folha de celulose produzida, ou seja, maior a chance de quebra da placa de celulose durante a produção dos jumbos e das bobinas menores.

\subsubsection{Empresa produtora de papel e celulose situada em São Paulo}

Em Junho de 2012 foi realizada uma visita técnica em uma planta fabril situada no interior do estado de São Paulo. A fábrica atende demanda nacional e internacional, sendo que cerca de $70 \%$ da produção é exportada. A empresa tem semelhanças com relação a empresa portuguesa estudada em Santos e Almada-Lobo (2012), variando em alguns pontos como, por exemplo, no número de linhas de produção, isto é, na quantidade de máquinas de papel. Nesta fábrica, as duas máquinas de papel são alimentadas por um único digestor, enquanto na empresa portuguesa havia apenas uma máquina e um digestor dedicado a esta máquina. A seguir, as características desta empresa em comparação as demais empresas visitadas são detalhadas:

- Matéria prima

As empresas produtoras de celulose no Brasil utilizam em sua maior porção madeira proveniente de plantios de Eucalipto. As duas empresas brasileiras visitadas têm $100 \%$ da madeira proveniente deste tipo de plantio, devido principalmente a maior produtividade, ao tipo de fibras obtidas (celulose de fibra curta) e as questões ambientais. No Brasil, florestas de eucalipto chegam ao ponto de corte em 7 anos ou menos, enquanto coníferas como o pinus, demoram cerca de 15 anos para alcançarem o ponto de corte. No caso de países em regiões subtropicais, as coníferas têm vantagens, devido a melhor adaptação climática, e são largamente utilizadas. Conforme o processo logístico, a madeira cortada pode permanecer até 60 dias em campo (secando) e até 120 dias no pátio (estoque de segurança).

\section{- Digestores}

A empresa paulista conta com apenas um digestor contínuo que abastece duas linhas de produção. Como em outras empresas, existe a adoção de estoque intermediário de celulose. No caso da empresa baiana visitada, existem duas linhas de produção, nas quais cada máquina de papel é abastecida por um conjunto de digestores dedicados que trabalham por bateladas. Além disso, na planta de São Paulo, a velocidade de trabalho do digestor é variada em passos discretos de 0,3 RPM (rotações por 
minuto), similar ao descrito no estudo de caso de Santos e Almada-Lobo (2012).As máquinas de papel consomem cerca de $95 \%$ da produção de celulose, o restante da produção é enviado a uma linha chamada de "desaguadora", onde são produzidas placas com $50 \%$ de celulose e $50 \%$ de água. O estoque desta celulose pode ser utilizado de duas maneiras: atendendo demanda das linhas, no caso de uma parada do digestor (quebra ou manutenção), e atendendo demanda de empresas parceiras.

\section{- Celulose}

A celulose é branqueada em sua totalidade, com perdas desprezíveis no processo. A dificuldade de branqueamento da celulose está atrelada a uma característica do processo de cozimento chamada Kappa. O fator Kappa define a quantidade de lignina que é mantida na celulose e consequentemente a taxa de produção, dado que quanto maior o Kappa maior a produtividade e maior a quantidade de lignina. No entanto, a lignina dificulta o processo de branqueamento. A empresa paulista não utiliza celulose de fonte externa e não adicionada celulose reciclada no processo produtivo. Isto também não ocorre no caso da empresa baiana, pois a demanda por pureza impossibilita o uso deste tipo de matéria-prima.

- Máquinas de papel (linhas de produção)

Existem duas máquinas de papel na planta paulista, sendo que atualmente o sequenciamento da produção utiliza a seguinte regra: a primeira máquina de papel produz gramaturas variadas e a segunda produz apenas a gramatura de maior demanda, no caso, $75 \mathrm{~g} / \mathrm{m}^{2}$ (gramas por metro quadrado). Esta regra só se torna vantajosa quando a demanda de um item é equivalente a capacidade produtiva de uma ou mais máquinas de papel. A velocidade das máquinas de papel é bem similar, variando a produção em cerca de 1200 metros por minuto. O papel produzido é enrolado em grandes bobinas jumbos de aproximadamente 20 toneladas cada e tem as seguintes características:

- Porcentagem de celulose: 78,9\%

- Porcentagem de água: $5 \%$

- Aditivos (amido de milho, alvejante ótico e cola): 16,1\%

O amido de milho e a cola são adicionados a celulose para selar o papel. Como o papel produzido não é utilizado com a função absorvente (principalmente papéis de impressão), os aditivos devem reduzir o poder de absorção de líquidos da celulose, e isto é feito com a adição destes produtos. O alvejante ótico é adicionado 
para completar o processo de branqueamento da celulose, que neste ponto tem tom violeta devido aos processos anteriores. A gramatura dos papéis produzidos varia de 50 até $105 \mathrm{~g} / \mathrm{m}^{2}$. Estes valores são bem diferentes dos apresentados na empresa portuguesa estudada em Santos e Almada-Lobo (2012), que tem produção variando entre 115 e $300 \mathrm{~g} / \mathrm{m}^{2}$. Isto se deve aos distintos fins dos papéis produzidos, pois a empresa portuguesa produz papéis para embalagens, que demandam maior resistência. Atualmente a programação da produção é feita de acordo com a carteira de pedidos e a modificação nas gramaturas produzidas na primeira máquina de papel são feitas de acordo com uma sequência pré-estabelecida.

- Bobinadoras

As bobinadoras fazem o corte dos jumbos em bobinas menores para atender a demanda dos clientes e a demanda interna das máquinas de corte (cortadoras). A demanda por bobinas, por parte dos clientes, corresponde a $23 \%$ da demanda total da empresa. O restante dos jumbos são cortados em bobinas com 2,35m e 1,35m de largura e cerca de 3 toneladas, de acordo com a capacidade das máquinas de corte.

\section{- Cortadoras}

Existem 3 linhas de cortes responsáveis pela transformação de bobinas em retângulos. Estas linhas cortam papéis no padrão A4, denominada internamente de Cut-size, e no padrão Folio, denominada Folio-size. As demandas destes dois tipos de produtos representam cerca de $67 \%$ e $10 \%$ da demanda total, respectivamente. As duas primeiras linhas de corte suportam bobinas de 2,35 metros. A primeira linha produz a uma taxa de 90 resmas por minuto e a segunda linha produz a uma taxa de 135 resmas por minuto. Resma é um padrão internacional que atualmente corresponde a 500 folhas de papel. A terceira linha de corte trabalha com bobinas de 1,35 metros e produz 80 resmas de papel por minuto.

- Recuperação química

O processo de recuperação química é idêntico ao apresentado na Seção 2.3.1. O licor negro fraco, resíduo do cozimento da madeira, passa por dois processos de condensação da água (evaporação), que aumentam sua concentração de $16 \%$ para $22 \%$ e posteriormente para $70 \%$. O licor negro a $70 \%$ de concentração é queimado e produz resíduos sólidos e vapor de alta pressão. O vapor de alta pressão é enviado às turbinas que geram energia elétrica e posteriormente é utilizado em alguns processos produtivos como, por exemplo, o processo de secagem do papel. A caldeira de recuperação tem capacidade para gerar 200 toneladas de vapor por hora. Além 
disso, existem duas caldeiras auxiliares que produzem vapor de baixa pressão e cada uma tem capacidade de gerar 50 toneladas de vapor por hora. Estas caldeiras são alimentadas com biomassa ou óleo, no caso de falta de biomassa. A biomassa consiste dos rejeitos da matéria prima como, por exemplo, casca e cavacos de madeira fora das especificações desejadas. Os resíduos sólidos da queima do licor negro, denominados lama verde, passam por um processo de caustificação, no qual boa parte do dióxido de cloro é recuperado. Em todo o processo, são perdidos em média 15 quilogramas de dióxido de cloro para cada tonelada de celulose produzida.

- Considerações adicionais

A água foi apontada como um recurso importante no processo produtivo da celulose. Nesta planta fabril, a obtenção de água é feita em um rio, com a utilização de três bombas e uma capacidade total de 5.250 metros cúbicos por hora. Os tratamentos de afluentes são feitos e existe um controle contínuo da qualidade da água que é descartada no rio. Segundo os dados mostrados na visita, o processo aplicado gera redução de poluentes superior às exigidas pelos órgãos competentes.

\subsubsection{Empresa produtora de papel e celulose situada em Portugal}

Em Abril de 2013 a empresa portuguesa estudada por Santos e Almada-Lobo (2012) também foi visitada. O processo produtivo da empresa portuguesa é composto por um digestor, uma máquina de papel, uma linha de recuperação química, uma fábrica associada de produção de celulose reciclada e tanques de estocagem de celulose virgem, celulose reciclada, licor negro fraco e licor negro concentrado.

Como verificado na empresa paulista, o digestor de produção observado na empresa portuguesa trabalha de forma contínua, sendo responsável por atender a demanda de apenas uma máquina de papel. Existe uma fábrica associada de produção de celulose reciclada, fato que difere das fábricas visitadas no Brasil. Todos estes componentes e os tanques de celulose virgem e celulose reciclada pertencem a denominada planta de celulose. O objetivo principal desta planta é maximizar a produção de celulose, no entanto, a produção deve ser limitada pelas capacidades produtivas das demais plantas. Como ocorrido no caso da empresa paulista, a variação na velocidade do digestor é feita em passos discretizados no tempo e limitados a determinados valores durante o horizonte de tempo de planejamento. Este limite na variação de velocidades subsequentes é determinado pelo fabricante do digestor e garante que o mesmo mantenha estabilidade e regularidade na produção. A produção de celulose e, consequentemente de licor negro, é determinada de 
acordo com a velocidade de trabalho do digestor.

A conexão entre as plantas produtivas é feita pelo controle dos estoques intermediários de celulose virgem, celulose reciclada e licor negro fraco. Esta conexão é tratada em Santos e Almada-Lobo (2012) como uma estrutura produtiva de dois estágios, no qual o primeiro estágio é representado pela planta de celulose e o segundo estágio é composto pelas plantas de papel e recuperação química. Todo o processo é sincronizado no tempo para que o controle dos limites de estoque possam ser feitos.

Com o objetivo de produzir papel pardo para embalagens, o processo produtivo da empresa portuguesa não tem a etapa de branqueamento da celulose e faz adição de celulose reciclada na composição do produto final. Nesta empresa foi verificada a existência de duas famílias distintas de papéis. A primeira, chamada de KLB (Kraft Liner Board), é composta por cerca de $65 \%$ de celulose virgem e $35 \%$ de celulose reciclada. Enquanto que a segunda, denominada de VLB (Viana Liner Board), tem a composição oposta, ou seja, cerca de $35 \%$ de celulose virgem e $65 \%$ de celulose reciclada. A fábrica de celulose reciclada utiliza resíduos da produção, como os papeis perdidos durante as quebras e as trocas de produção na máquina de papel, porém, aparas de papel também podem ser utilizadas na produção. As pastas de celulose virgem e reciclada são armazenadas em tanques para posterior utilização na máquina de papel, sendo que estes tanques possuem limites máximos e mínimos de armazenamento.

Na planta produtora de papel é feita a mistura das celuloses, de acordo com a qualidade de papel que será produzido. Cada tipo de papel é definido por duas características: gramatura dada em $\mathrm{g} / \mathrm{m}^{2}$ (gramas por metro quadrado) e proporção de celulose reciclada integrada a mistura. Durante a mudança do tipo de papel a ser produzido não ocorre interrupção da produção e a máquina produz um papel fora de especificação, que pode ser utilizado como matéria-prima na fábrica de celulose reciclada. No final do processo, o papel produzido é enrolado em jumbos, as quais são cortadas em bobinas menores para o atendimento das demandas dos clientes.

A planta de recuperação de resíduos contém cinco etapas, sendo idêntica as das duas fábricas visitas anteriormente. Na primeira etapa, o licor negro vindo do digestor é armazenado em um tanque de estocagem, que contém limite mínimo e máximo de capacidade. Este licor produzido no digestor é denominado licor negro fraco, pois é constituído em sua maioria por água. O licor negro fraco passa por processos de condensação da água (licor negro concentrado) e queima, gerando a produção de vapor e energia elétrica. Os reagentes químicos são recuperados no final do processo, como descrito anteriormente. 
As unidades de evaporação e a caldeira de recuperação têm capacidades limitadas e os tanques de armazenamento são utilizados para suavizar o processo.

\subsection{Problemas revisados na literatura}

Vários problemas associados a indústria de papel e celulose foram investigados na literatura. Estes podem ser encontrados na forma de estudos de casos e estudos de subproblemas encontrados neste setor industrial como, por exemplo, problemas de corte de bobinas para o atendimento da demanda dos clientes e problemas de planejamento da produção e de alocação de pedidos as máquinas de papel. Em particular, o problema de utilização de resíduos para a produção de vapor e energia é considerado em Svensson et al. (2008) e Jönsson et al. (2008). Claassen (2014) aborda o problema de mistura de tipos de celulose associado a alocação de refinadores que homogenizam a mistura. Castro et al. (2014) consideram o problema de sequenciamento da produção em um sistema com múltiplos digestores, que produzem por bateladas e que competem por recursos de aquecimento. O problema de dimensionamento e sequenciamento de lotes associado ao problema de entrega dos produtos é tratado por Silva et al. (2014). Problemas de dimensionamento de lotes acoplados ao problema de corte de jumbos são abordados em Poltroniere et al. (2008) e Correia et al. (2012). Problemas acoplados de dimensionamento de lotes e sequenciamento da produção são abordados em Figueira et al. (2015), Figueira et al. (2013) e Santos e Almada-Lobo (2012).

Em Schumacher e Sathaye (1999) é feito um estudo para averiguar estatisticamente o desempenho da indústria nacional indiana com relação as práticas do mercado internacional do setor. Neste trabalho, os autores verificam a possibilidade de variação no processo produtivo de acordo com o tipo de demanda de papel e o porte da indústria. Após a definição do processo produtivo, os autores apresentam um estudo histórico demonstrando os impactos de atos políticos de protecionismo da indústria indiana, por meio de altas taxas de importação. Os autores apresentam os fatores como restrições de recursos do processo produtivo (tempo de máquina, tempo de funcionários, entre outros), uso de energia, impacto ambiental e políticas protecionistas para o setor, como possíveis responsáveis pela diferença tecnológica entre empresas indianas e empresas de outros países. $\mathrm{Na}$ análise estatística histórica, os autores analisam o crescimento do mercado consumidor e de produtividade, e fazem um estudo comparativo do desempenho da indústria indiana com a prática internacional, demonstrando a ineficiência energética da indústria indiana. Segundo os autores, esta ineficiência se deve ao grande número de empresas de pequeno 
e médio porte existente, onde o controle de poluentes se torna mais difícil e a reutilização de resíduos da produção para a geração de energia (em forma de vapor e energia elétrica) se torna inviável economicamente. Ainda neste estudo, os autores indicam as vantagens da adição de celulose reciclada para a produção de papel, pois a celulose reciclada não passa pelo processo de cozimento e não produz resíduos químicos, reduzindo o consumo energético e o volume de água poluída no processo produtivo.

Respicio et al. (2002) estudam um problema integrado de forma hierárquica para dar suporte a decisão de planejamento e sequenciamento da produção em industrias de papel e celulose. Este planejamento da produção contém uma etapa para prever a demanda e auxiliar a aceitação dos pedidos. Também são definidos neste problema os padrões de corte dos jumbos e são determinados os tamanhos e o sequenciamento dos lotes produzidos na máquina de papel. Os variados subproblemas são resolvidos por meio de heurísticas associadas em um sistema de suporte a decisão. A previsão da demanda é feita utilizando uma rede neural supervisionada e os padrões de cortes são construídos por meio do método de programação dinâmica de Gilmore e Gomory (1963). O sistema de suporte a decisão faz uma alocação inicial do estoque para atender os pedidos com data de entrega mais próxima antes de iniciar qualquer processo de planejamento da produção. Esta alocação pode ser aceita integralmente, parcialmente ou rejeitada pelo usuário. A etapa de aceitação de pedidos verifica custos e perdas gerados com a inclusão do novo pedido. Em caso de falta de capacidade produtiva, apresenta alternativas ao usuário como, por exemplo, atrasar entregas e modificar quantidades demandadas. O planejamento da produção na máquina de papel é feito por meio da demanda necessária para o atendimento das máquinas de corte. Esta demanda é dividida em bateladas e alocada às máquinas de papel de acordo com a regra de Schutten (1996). Segundo os autores, o sistema torna a tomada de decisão, baseada em um conjunto de soluções de alto nível, mais racional. Além disso, considerando todos os processos, o sistema aumenta a coordenação entre as unidades produtivas e promove a cooperação entre marketing e produção.

Em Keskinocak et al. (2002) é abordado um problema integrado de alta complexidade de uma grande produtora de papel e celulose estadunidense. São consideradas múltiplas plantas produtivas com múltiplas máquinas de papel, bobinadeiras e veículos para transporte. O problema consiste em definir, de forma integrada, a alocação de pedidos as plantas, o planejamento e sequenciamento da produção de cada máquina de papel, a definição e sequenciamento dos padrões de corte aplicados e o planejamento das cargas de cada veículo. O problema é resolvido por meio de um método de solução baseado em agentes cooperativos, chamado A-Team (Asynchronous Team Framework). O mé- 
todo é um framework onde diversas heurísticas (agentes) trabalham em conjunto sobre um conjunto de soluções (população), criando novas soluções (agentes de construção), melhorando soluções existentes (agentes de melhoria) ou destruindo soluções de baixa qualidade (agentes destruidores). Neste trabalho, os autores optam por desenvolver um método multiobjetivo que considera métricas que maximizem os lucros, a satisfação dos clientes e a eficiência da produção. Para cada nível do problema (unidade produtiva), são criadas heurísticas construtivas e de melhoria que considerassem características das demais unidades. Além disso, é permitido aos tomadores de decisão modificar e adicionar novas soluções por meio de uma ferramenta com interface gráfica. Isto aproveita de forma mais efetiva o conhecimento de tomadores de decisão experientes no processo. Segundo os autores, a aplicação da ferramenta teve um grande impacto na redução de custos da empresa, considerando as perdas de corte (redução de seis toneladas de aparas por dia) e no custo de distribuição (cerca de 10\%). O resultado final é uma redução de milhões de dólares nos custos da empresa, além de aproximar os setores produtivos do setor de marketing e vendas, que também se utiliza da ferramenta para prever impacto de demandas, definir datas de entrega, entre outros.

Rizk et al. (2004) apresentam uma modelagem matemática e algumas desigualdades válidas para um problema de dimensionamento de lotes na indústria de papel e celulose com múltiplas máquinas de papel. Neste caso, uma sequência de produção pré-definida deve ser respeitada. Os autores dividem a linha produtiva em quatro níveis sequencialmente dispostos: planta de cavacos, planta de celulose, planta de papel e acabamento. Segundo os autores, as máquinas de papel são frequentemente o gargalo de produção e, por este motivo, os planos de produção devem ser definidos em termos da alocação deste recurso. Ainda segundo os autores, o maior desafio no planejamento da produção se encontra no fato de sincronizar o fluxo de materiais dentro dos estágios de produção e acabamento, atendendo a demanda dos clientes e reduzindo custos operacionais.

Bouchriha et al. (2007) estudam um problema de dimensionamento de lotes com múltiplos tipos de papéis, limitação da capacidade da máquina de papel e custos de preparações dependentes da sequência. Como em Rizk et al. (2004), uma sequência de produção predeterminada dos itens com demanda deve ser mantida. Para a solução deste problema, os autores propõem uma abordagem em três passos. No primeiro, o tamanho de ciclo é definido a partir de uma função de custos de preparações e de estocagem. A função é definida pelos autores, utilizando médias históricas de demanda, custos de preparações e de estocagem. O tamanho do ciclo de produção é utilizado como referência para o tamanho dos períodos do horizonte de planejamento. No segundo passo, o problema de 
dimensionamento de lotes é resolvido com restrições adicionais que obrigam a produção de todos os tipos de papéis presentes no ciclo pré-definido. No terceiro passo, a restrição de produção de todos os tipos de papéis em cada período é eliminada. Desta forma, os autores demonstram o quanto pode ser economizado com a eliminação de preparações e redução de estocagem. A abordagem proposta foi aplicada em um estudo de caso em uma empresa canadense, onde os autores verificaram alguns cenários de custos de estoque e preparação, para definir o melhor tamanho de ciclo. Para essa empresa, os autores verificaram que ciclos de uma ou duas semana apresentavam melhores resultados. Além disso, verificaram que a eliminação das restrições de sequência fixa de produção reduziu os custos em 2,14\%, para os cenários analisados.

Svensson et al. (2008) e Jönsson et al. (2008) estudam a competição interna e externa pelo vapor produzido na queima de resíduos da produção de celulose. A utilização interna do calor se refere ao uso em etapas do próprio processo de produção da celulose e/ou na produção de energia elétrica, dependendo da qualidade do calor excedente. A utilização externa do calor se refere ao abastecimento de usinas de aquecimento urbano, substituindo a utilização de outros tipos de combustíveis. Os trabalhos foram feitos como um estudo de caso em empresas suecas próximas a usinas de aquecimento urbano e foram apresentados em duas partes: em Svensson et al. (2008) é apresentada a metodologia proposta para abordar este tipo de problema; em Jönsson et al. (2008) é aplicada a abordagem de Svensson et al. (2008) para um estudo de possíveis cenários futuros no mercado de energia.

Svensson et al. (2008) consideram um sistema contendo uma companhia de aquecimento distrital e uma empresa produtora de celulose, a fim de desenvolver um planejamento integrado para obter solução ótima de desempenho energético. No sistema integrado são analisados os custos de investimento, de combustíveis e eletricidade, de manutenção, e os lucros com a venda de energia produzida. Além disso, considerou-se o impacto ambiental, na forma de emissões de gases carbônicos. O estudo aborda usinas de aquecimento de pequeno, médio e grande porte, e consideram três cenários distintos quanto ao investimento. No primeiro cenário, é permitido o investimento em equipamentos mais modernos que sejam mais eficientes. No segundo cenário, investimentos não são possíveis. O terceiro cenário é uma solução alternativa ao primeiro cenário, na qual é obtida a segunda melhor solução do sistema com investimentos. Para avaliar cada cenário foi utilizado o custo para a produção de vapor, além da redução das emissões de gás carbônico.

Jönsson et al. (2008) aplicam a abordagem de Svensson et al. (2008) para uma série 
de cenários de mercados de energia. Segundo os autores, os resultados demonstram que a competição entre a utilização interna e externa do calor excedente depende dos preços dos combustíveis alternativos, da demanda de aquecimento do distrito e do tipo de produção de calor existente na região. Do ponto de vista econômico, o uso externo do calor excedente na produção de celulose é sempre preferível para companhias de aquecimento de pequeno porte. Para companhias de médio e grande porte, a opção de uso externo ou interno varia de acordo com o cenário do mercado. Do ponto de vista ambiental, o uso externo do calor excedente é sempre preferencial dada a grande redução na emissão total de gases.

Poltroniere et al. (2008) consideram o problema de dimensionamento de lotes que consiste na determinação da produção dos jumbos e o problema de corte unidimensional dos jumbos em bobinas menores, que visa a demanda dos clientes. No problema de dimensionamento de lotes são considerados múltiplos itens (diferentes tipos de papel), múltiplas máquinas de papel com restrições de capacidade, tempos e custos de preparação de máquina não-nulos, preparações de máquinas independentes da sequência e estoques de produtos finais e de jumbos. Devido a dificuldade de solução do problema acoplado, os autores propuseram duas heurísticas baseadas na decomposição do problema integrado. O primeiro método de solução baseia-se na relaxação lagrangiana da restrição de acoplamento. Desta forma, a programação da produção de jumbos é feita (dimensionamento de lotes) e posteriormente múltiplos problemas de corte unidimensional são resolvidos, sendo um para cada período e tipo de papel. No segundo método, os passos de resolução dos subproblemas são invertidos. Primeiro resolve-se o problema de corte, considerando um determinado número de jumbos. A partir desta solução, o problema de planejamento da produção de jumbos é resolvido, com o intuito de minimizar os custos de produção, de estoque de jumbos e de preparação de máquina. Em seguida, o problema de corte é novamente resolvido, desta vez com a produção de jumbos definida pela resolução do problema de dimensionamento de lotes. Isto é feito de forma iterativa até que um critério de parada seja satisfeito. Foram utilizados dois critérios de parada, número máximo de iterações e ausência de melhoria após a resolução dos dois subproblemas.

Malik e Qiu (2008) fazem uma revisão de trabalhos que abordam problemas de gestão da cadeia de suprimentos encontrados em empresas do setor de papel e celulose. Os autores analisam a aplicação de estruturas clássicas de planejamento da produção como, por exemplo, ferramentas de planejamento das necessidades de materiais (Material Requirement Planning - MRP), planejamento dos recursos de manufatura (Manufacturing Resource Planning - MRP II) e modelos matemáticos como o EOQ (Economic Order Quantities) e o ELSP (Economic Lot Scheduling Problem). Além de verificar a aplica- 
ção de estruturas mais modernas e complexas de planejamento, como o planejamento de recursos empresariais (Enterprise Resource Planning - ERP), planejamento hierárquico e a combinação entre estruturas de produção Make-to-Order e Make-to-Stock. Dois tópicos para trabalhos futuros foram apresentados nesta revisão. O primeiro consiste em estudar maneiras de definir um planejamento simultâneo da produção nas várias plantas produtivas da empresa, considerando os fluxos de produtos em empresas integradas de papel e celulose. O segundo tópico consiste em estudar as características estocásticas do lead-time de produção encontrado neste tipo de processo produtivo. Lead-time é o tempo necessário para que um item intermediário de produção passe de uma etapa produtiva para a etapa seguinte.

Carlsson et al. (2009) descrevem os trabalhos que trataram problemas de planejamento da cadeia de suprimentos aplicados a indústria de papel e celulose, tal como Malik e Qiu (2008). Os autores definem a cadeia de suprimentos, desde a aquisição de matéria prima até a cadeia de vendas dos produtos finais, e apresentam uma matriz de tarefas de níveis estratégico, tático e operacional para cada uma destas etapas da cadeia. Neste artigo é feita uma revisão das ferramentas comerciais e dos trabalhos científicos que tratavam problemas da área. Nem sempre as ferramentas comerciais são suficientes para atender a demanda das empresas. Além disso, não são encontrados muitos trabalhos científicos neste tópico, indicando a necessidade de trabalhos adicionais. Segundo os autores, estes trabalhos podem agregar, por exemplo, incerteza aos modelos desenvolvidos.

Castro et al. (2009) desenvolvem um estudo de caso em uma empresa produtora de lenços de papel. O problema estudado consiste em determinar os tempos de ciclos de produção ótimos, enquanto maximiza o lucro e atende uma demanda mínima de vários produtos finais. São desenvolvidos duas formulações baseadas em redes de suprimentos, sendo uma com tempo dividido de forma contínua e outra baseada em uma discretização do tempo. A formulação contínua tem intervalos de tempo de produção dos itens dentro do ciclo de produção definidos pelo modelo matemático, resultando em um modelo matemático não linear inteiro misto (MINLP). Por outro lado, o modelo discreto tem o tempo dividido em intervalos de tamanho igual e pode ser resolvido por meio de modelo linear inteiro misto (MILP) para cada tamanho distinto de ciclo. Além disso, os autores desenvolveram um método de solução de dois passos para a formulação contínua. No primeiro, são resolvidos MILPs para variados tamanhos de ciclos, de forma similar ao que ocorre na formulação discretizada. Em seguida, estes resultados são usados como base para definir os ciclos ótimos de produção por um problema reduzido do tipo MINLP. 
Correia et al. (2012) consideram um problema integrado de alocação e sequenciamento de produção em múltiplas máquinas de papel associado ao problema de corte das bobinas jumbo. Diferente do ocorrido em Poltroniere et al. (2008), as bobinas são cortadas em bobinas menores e retângulos de papel (corte bidimensional) para atender a demanda dos clientes. Neste problema também são consideradas $K$ diferentes gramaturas de papéis a serem produzidas nas múltiplas máquinas de papel, variando quanto ao tipo de preparação de máquina considerada. Correia et al. (2012) consideram que as perdas com preparação de máquina são dependentes da sequência, pois aumentam com mudanças entre papéis de gramaturas mais distintas. Isto gera a necessidade de construção de sequências de produção mais eficientes nas máquinas de papel. Os autores propõem uma abordagem de solução em 3 passos, denominada $A S C$-3Steps, pois segundo eles, o investimento em determinar a solução ótima para o problema integrado é questionável se considerarmos a incerteza em certos parâmetros do modelo (custos de transição, capacidade de máquina, tolerâncias de produção, entre outros). No primeiro passo, a partir de uma expectativa de demanda de papel para o processo de corte, o método gera uma alocação inicial de produção na máquina de papel. O segundo passo consiste em definir o sequenciamento de produção em cada máquina de papel, resolvendo o problema do caixeiro viajante pela heurística do vizinho mais próximo. No terceiro passo são feitos ajustes, trocando lotes de produções entre as máquinas, que procuram eliminar infactibilidade e reduzir a quantidade de papel necessária para atender a demanda. Este terceiro passo é executado repetidamente até que não haja melhoria na solução.

Santos e Almada-Lobo (2012) consideram um problema integrado de planejamento da produção em uma empresa portuguesa produtora de papel e celulose. A planta produtiva considerada é composta por um digestor, uma máquina de papel, tanques de estoques intermediários e uma linha de recuperação química. Os autores utilizam a heurística relaxand-fix (relaxe-e-fixe) para obtenção da solução inicial e a heurística fix-and-optimize (fixee-otimize) como método de melhoria. O processo de resolução em uma heurística relaxee-fixe consiste em inicialmente relaxar linearmente as variáveis de decisão do problema e, em seguida, iterativamente integralizar e fixar estas variáveis, que são divididas em conjuntos disjuntos de variáveis. A cada iteração é resolvido um subproblema inteiro misto, onde as variáveis de um dos conjuntos é integralizada. A heurística fixe-e-otimize se baseia também no particionamento do conjunto de variáveis inteiras em subconjuntos disjuntos, fixando e liberando as mesmas para otimização a cada iteração. A cada passo desta heurística, uma partição fica "livre" para ser otimizada e as demais são fixadas no valor da solução incumbente. 
Figueira et al. (2013) tratam um problema similar ao apresentado por Santos e Almada-Lobo (2012). Duas características adicionais são consideradas neste trabalho: a produção das máquinas de papel é definida dentro de ciclos de produção com tamanho fixo e pré-estabelecido, as demandas atrasadas no início de cada ciclo produtivo devem ser totalmente atendidas até o final do mesmo ciclo e todos os ciclos se iniciam produzindo uma gramatura em comum previamente definida pelo tomador de decisões. Para resolver o problema, os autores propõem uma metaheurística do tipo VNS e comparam os resultados com a heurística baseada na formulação matemática de Santos e Almada-Lobo (2012) e com a ferramenta de solução comercial Cplex.

Claassen (2014) trata o problema de mistura de tipos distintos de celulose associado a alocação de equipamentos denominados refinadores. Os refinadores homogenizam a mistura até que esta atinja as características desejadas pelo produto final. Esta pasta é então enviada a máquina de papel em combinação com a pasta de um ou mais refinadores, para gerar o produto final, de acordo com a gramatura e tipo de papel demandados. O problema é formulado via programação fracional (SCHAIBLE; IBARAKI, 1983) e os autores propõem uma nova forma de computar a mistura das propriedades desejadas nas pastas. Programação fracional é uma vertente da programação não linear que estuda problemas do tipo max-min, aos quais são caracterizadas por uma ou várias razões entre funções dadas. A nova forma de calcular a mistura da pasta é feita com base no volume dos componentes misturados, em contraste com a forma clássica de definição baseada na massa destes componentes. Além disso, os autores se utilizam de nova maneira de formular a programação fracional, utilizando variáveis discretas binárias, e desenvolvem um método de solução do tipo branch-and-bound para resolver o problema e eliminar soluções não discretas.

Castro et al. (2014) abordam o problema de definir o ciclo de sequenciamento de uso dos digestores, com foco na complexa iteração entre digestores durante o aquecimento no processo de cozimento dos cavacos de madeira para a extração da celulose. Um modelo matemático com tempo contínuo é proposto, baseado em conceitos de múltiplas grades de tempo. Este modelo é proposto como uma alternativa aos modelos discretos e contínuos baseados em conceitos de redes (State-Task Network (STN) e Resource-Task Network (RTN)), como o modelo matemático de Castro et al. (2009). Os autores comparam os resultados com os valores apresentados nos estudos da literatura e verificam que o modelo proposto é mais apertado e não necessita de um método de solução para encontrar o tempo de ciclo ótimo, podendo ser resolvido via ferramentas de solução comerciais. 
Goulimis et al. (2014) apresentam uma ferramenta computacional de auxílio a tomada de decisão de planejamento da produção em empresas do setor de papel e celulose. Os autores apresentam algumas características que definem a forma como a tomada de decisões é comumente feita no setor. Eles discutem que, por exemplo, decisões de sequenciamento da produção são feitas de forma manual ou semi-manual, uma tarefa complexa e que demanda tempo e experiência por parte do tomador de decisão. Avaliam ainda que soluções alternativas são pouco verificadas e a metodologia utilizada no planejamento da produção depende da experiência exclusiva do tomador de decisão. No entanto, não foi apresentado neste artigo a forma como foi desenvolvido o método de solução interno de sua ferramenta, nem foi definido em detalhes o funcionamento da ferramenta, sugerindo apenas ganhos de desempenho e que a interface é amigável.

Kallrath et al. (2014) estudam o problema de corte uni e bidimensional do ponto de vista da indústria de papel, ou seja, o corte de bobinas e placas a partir das bobinas mestres geradas em uma máquina de papel. Porém, o problema de dimensionar os jumbos não é considerado. Eles desenvolveram técnicas de solução que foram integradas a um sistema de planejamento de recursos empresariais (ERP - enterprise resource planning). Estas abordagens visam minimizar simultaneamente a quantidade de bobinas mestre cortadas e o número de padrões utilizados, sem que haja sobre-produção. São desenvolvidas abordagens baseadas em geração de colunas e um método de exaustão para a resolução de problemas, que consideram a existência de jumbos de larguras distintas, com limitado número de bobinas em estoque ou situações onde existe a possibilidade de produção abaixo da demanda. Segundo os autores, os resultados se mostram promissores e indicam o possível uso de técnicas como um branch-and-price, por exemplo.

Figueira et al. (2015) desenvolvem um sistema de suporte a decisões para a empresa produtora de papel e celulose considerada em Santos e Almada-Lobo (2012), onde são incorporados importantes características industriais, que motivaram o desenvolvimento de um novo modelo matemático. São considerados neste trabalho a integração entre os problemas de planejamento de um digestor, uma linha de recuperação química e uma máquina de papel. Associado a isto, foi considerado ainda o problema de entrega dos produtos finais (bobinas) para clientes com diferentes níveis de prioridades. Além disso, os autores discutem a importância da consideração de detalhes técnicos neste tipo de aplicação, como é o caso da criação de interfaces que sejam mais amigáveis com o usuário e quais as formas de incorporar métodos de otimização nas aplicações voltadas a usuários sem conhecimento de otimização. 
Alguns resultados derivados desta tese são reportados em Furlan et al. (2015). Neste trabalho, o modelo matemático de Santos e Almada-Lobo (2012) é estendido para o contexto de múltiplas máquinas produtoras de papel. Considerou-se que todas as máquinas produtoras de papel podem produzir qualquer um dos produtos demandados pelos clientes e que a velocidade de produção, tempos de preparação de máquina e consumo de matérias primas podem diferir entre as máquinas de papel. Um algoritmo genético com novos operadores de mutação e um processo de diversificação baseado em uma medida de dispersão da população é utilizado para abordar o problema tratado. O método proposto obteve resultados superiores aos apresentados pela ferramenta de solução MIP comercial na maioria dos casos, principalmente quando consideradas duas máquinas produtoras de papel. Quando comparado com os resultados obtidos pelo VNS de Figueira et al. (2013), o algoritmo genético se mostrou competitivo, sendo superior em alguns casos e inferior em outros.

A Tabela 1 apresenta um resumo dos trabalhos aqui revisados, de acordo com algumas características dos problemas abordados. Nesta tabela pode-se verificar que seis trabalhos consideram o uso de múltiplas máquinas de papel. Além disso, poucos trabalhos consideram problemas que integram as decisões de produção do digestor, das máquinas de papel e da linha de recuperação química. Por fim, não foram encontrados trabalhos anteriores a Furlan et al. (2015), que tratassem o problema em estudo. Como estas três plantas produtivas têm interconexão forte e o setor produtivo tem importante relevância econômica, mais estudos se fazem necessários para melhorar o entendimento deste problema. 


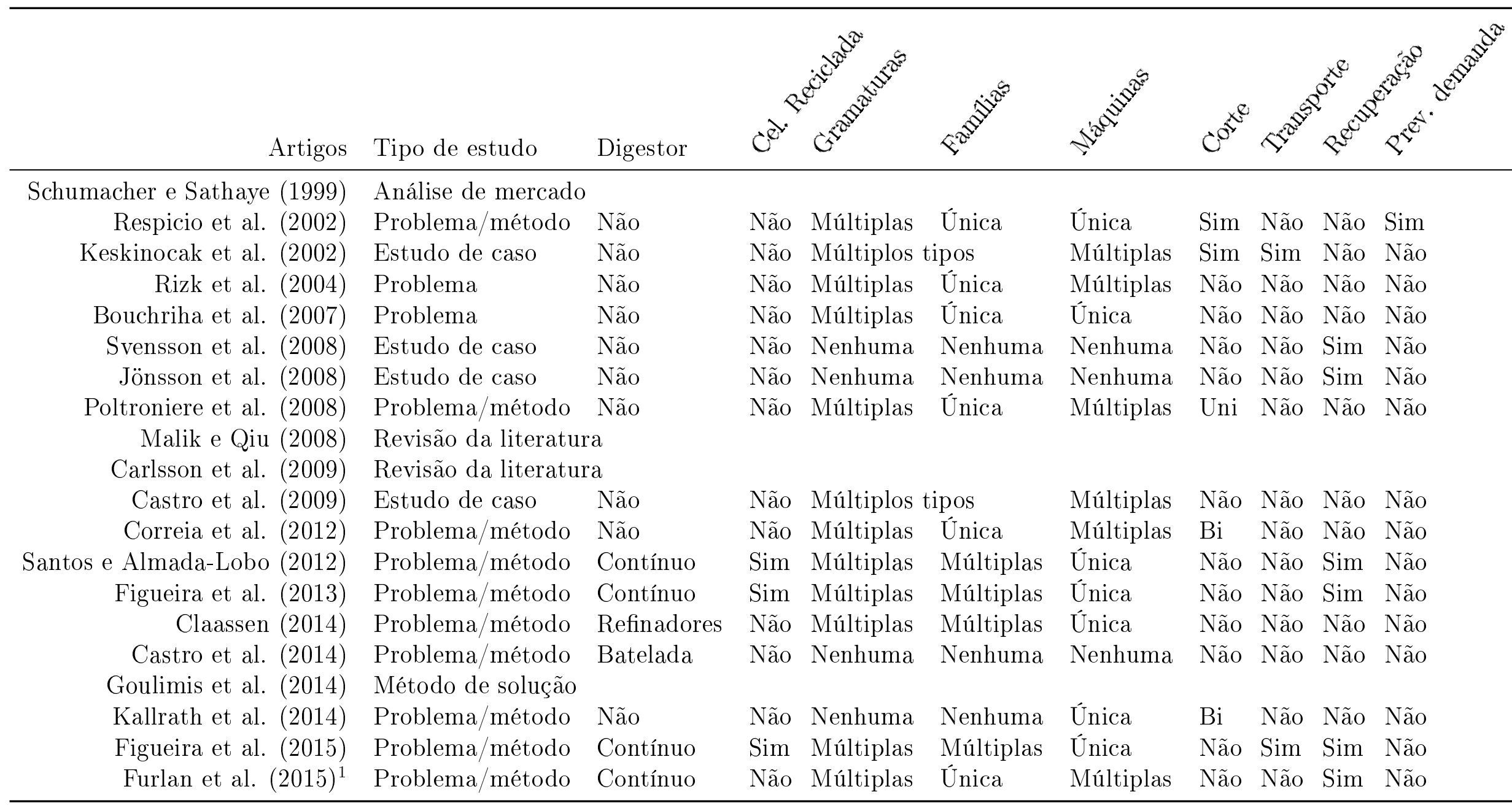

\footnotetext{
${ }^{1}$ Trabalho resultante de parte dos resultados desta Tese de doutorado.
} 


\subsection{Descrição do problema abordado}

A descrição do problema abordado nesta tese leva em consideração as características das empresas visitas e dos trabalhos de Santos e Almada-Lobo (2012) e Figueira et al. (2013). Considere a ilustração da Figura 3 para facilitar o detalhamento de cada planta e unidade produtiva considerada. Note que a fábrica é dividida em três plantas produtivas: planta de celulose, planta de papel e planta de recuperação, descrita a seguir:

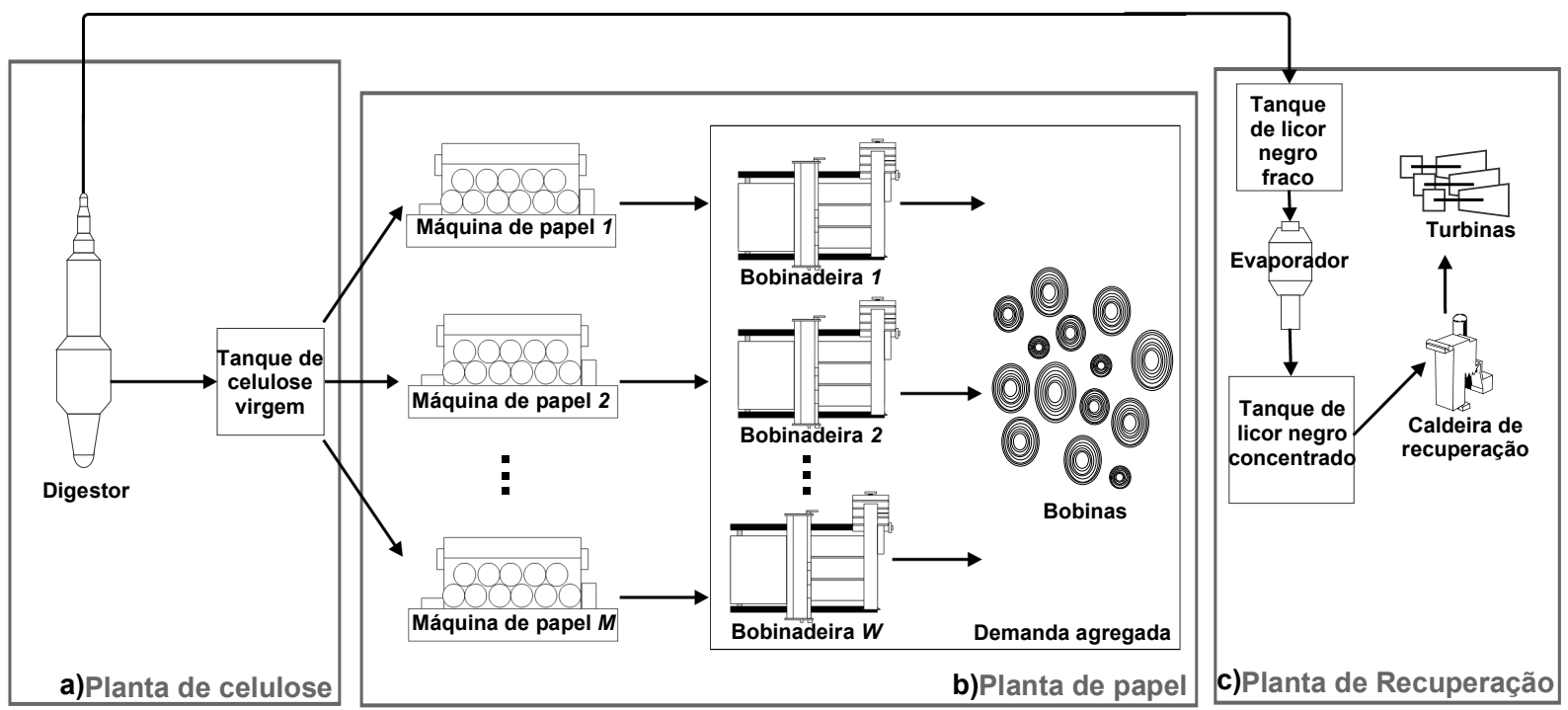

Figura 3: Ilustração do problema abordado neste trabalho.

- Planta de celulose:

A planta de celulose é composta por um digestor e um tanque de armazenamento de celulose (Figura 3a). Diferente do que ocorre em Santos e Almada-Lobo (2012), Figueira et al. (2013) e Furlan et al. (2015), não consideramos a mistura de celulose reciclada aos produtos finais, ou seja, os papéis são compostos apenas por celulose virgem produzida pelo digestor. A definição do problema considerou as características das empresas brasileiras, as quais não usam fibra reciclada devido ao tipo de papel produzido. Porém, a generalização do modelo matemático e das abordagens de solução aqui propostos podem ser facilmente estendidos para considerar uma empresa que incorpore celulose reciclada na produção de papéis.

O digestor trabalha de forma contínua e a taxa de produção de celulose/licor negro é determinada pela velocidade de trabalho do mesmo. Além disso, a velocidade é um ponto importante para o planejamento da produção nesta unidade crítica, pois sua variação é limitada para manter a estabilidade do equipamento. Foi considerado que apenas um digestor atende a demanda de todas as linhas de produção (máquinas de 
papel) e deposita a celulose virgem em um tanque de estocagem intermediário. O tanque de celulose têm limites mínimo e máximo que devem ser atendidos para que a pressão de entrada e saída sejam satisfeitas. A saída de celulose é independente para cada máquina de papel e elas competem apenas pela quantidade de celulose que existe no tanque, ou seja, a variação no consumo de uma máquina de papel não tem influência sobre o fluxo de saída para as demais.

- Planta de papel:

A planta de papel é composta por múltiplas máquinas de papel e bobinadeiras. A Figura 3b apresenta uma ilustração da planta de papel na qual $M$ máquinas produzem jumbos que são consumidas por $W$ bobinadeiras. Neste caso, cada máquina pode produzir jumbos para mais de uma bobinadeira e cada bobinadeira pode consumir jumbos de mais de uma máquina. A combinação de produção/consumo depende de dois fatores: o peso do jumbo e o seu comprimento. Cada máquina de papel/bobinadeira tem intervalos de aceitação para estas duas características dos jumbos que são produzidos/consumidos.

No problema em estudo foi considerada a existência de múltiplas linhas produtoras de papel, que tem o sequenciamento de produção independente, ou seja, não precisam produzir utilizando as mesmas sequências de produção. Todas as linhas podem produzir todos os itens demandados. A taxa de produção de cada linha é definida pela capacidade produtiva da máquina de papel, que se apresenta como gargalo produtivo desta planta ao desconsiderarmos o processo de corte dos jumbos. Existem custos, perdas e tempos associados as trocas de itens produzidos em cada máquina. Estes custos, perdas e tempos são definidos pelas características da máquina e pela sequência das gramaturas produzidas, ou seja, a preparação de máquina é dependente da sequência de gramaturas produzidas.

Como o problema de corte dos jumbos não foi considerado em detalhes, ao contrário, as demandas dos pedidos dos clientes foram agregadas em toneladas por gramatura e período. As demandas podem ser atendidas por apenas uma linha produtiva ou com a produção agregada das múltiplas linhas, pois não existe diferenciação entre produções das distintas máquinas. Esta diferenciação também não ocorre entre produções de períodos distintos. A entrega das demandas pode ser atrasada, mas sobre isto incorrem altos custos de atraso na entrega. Tanto os níveis de estoque quanto de atrasos na entrega dos itens finais não tem limite superior definido, sendo que estes valores são minimizados devido aos custos associados. 
- Planta de recuperação:

A planta de recuperação química é composta por tanques de estocagem de licor negro fraco e licor negro concentrado, evaporador, caldeira de recuperação e turbinas de geração de energia elétrica (Figura 3c). Esta linha de recuperação química contém as mesmas unidades críticas consideradas no estudo de caso de Santos e Almada-Lobo (2012). O licor negro fraco é produzido no digestor como resíduo do processo de cozimento da celulose. Em seguida, este licor é submetido a um processo de redução de água no evaporador. O licor negro concentrado, resultante deste processo de remoção de água, é estocado em um tanque para estocagem de licor negro concentrado. Posteriormente, este novo licor é queimado na caldeira de recuperação, gerando vapor e resíduos sólidos. As turbinas de geração de energia são responsáveis por aproveitar o vapor excedente para a produção de energia elétrica. O vapor é utilizado em várias partes do processo produtivo como, por exemplo, o cozimento da madeira e a secagem das folhas de papel. Como é muito caro ampliar a capacidade produtiva da caldeira de recuperação química, ela muitas vezes se torna o gargalo da linha produtiva e tem uma importância maior no planejamento da produção desta planta.

Como o processo produtivo neste setor industrial somente é interrompido em casos especiais como, por exemplo, quebras de maquinários e paradas para manutenções anuais programadas, foi considerado que não será aceita a ocorrência de sobra de capacidade na forma de tempo livre (idle-time). Portanto, toda a capacidade das máquinas de papel e do digestor devem ser consumidas com produção ou preparação de máquina. Além disso, deve haver um tempo mínimo de produção de cada gramatura após uma troca de produção, ou seja, existe um tamanho de lote mínimo que deve ser produzido após cada preparação de máquina. Um tempo mínimo também é requisitado para que possa haver trocas na velocidade do digestor, pois existe um tempo mínimo para que o equipamento possa estabilizar sua produção.

O processo produtivo apresentado na Figura 3 agrega características que não foram estudadas na literatura. Este problema pode ser visto como um caso mais geral dos problemas estudados em Santos e Almada-Lobo (2012) e Figueira et al. (2013). Em ambos os casos as estruturas de produção estudadas consideram apenas uma máquina produtora de papel. No caso estudado aqui, considerou-se múltiplas máquinas de papel que podem, em um caso específico, serem reduzidas a uma única máquina. Além disso, as considerações de ciclos de produção de Figueira et al. (2013) o tornam um caso mais 
específico de Santos e Almada-Lobo (2012), pois ao considerar características específicas de um processo de tomada de decisão os autores restringem o espaço de soluções do problema. 


\section{Modelagem matemática}

Este capítulo foi organizado da seguinte forma: uma breve revisão da literatura de modelos matemáticos para problemas de planejamento da produção é feita na Seção 3.1; as seções 3.2 e 3.3 apresentam em mais detalhes dois modelos matemáticos da literatura desenvolvidos para problemas de planejamento da produção em indústria integrada de papel e celulose; a Seção 3.4 apresenta o modelo matemático desenvolvido para o problema de planejamento da produção com múltiplas máquinas de papel e algumas restrições que foram desenvolvidas com base em práticas industriais verificadas durante visitas técnicas. Testes computacionais preliminares realizados para verificar o impacto e aplicabilidade destas restrições são apresentados na Seção 3.5.

\subsection{Revisão de modelos da literatura}

Recentemente tem crescido o interesse por problemas integrados de dimensionamento e sequenciamento de lotes motivados pela crescente integração destes problemas em várias situações práticas e também pelos desafios associados à integração de dois problemas amplamente tratados na literatura. O objetivo do problema de dimensionamento de lotes é definir quanto produzir e quanto produzir cada produto, de forma a atender a demanda dos clientes. Algumas características consideradas neste problema são: limitação na capacidade de recursos, possibilidade de atraso na entrega, perda de demanda, múltiplos níveis produtivos, preparação de máquina para a produção (in)dependente da sequência de produção, entre outros. Estas características variam de acordo com o sistema produtivo que está sendo estudado. Segundo Karimi et al. (2003), o dimensionamento de lotes se encontra no nível tático de planejamento.

O problema de sequenciamento da produção, por sua vez, envolve decisões mais de- 
talhadas para definir a sequência na qual a produção se dará no curto prazo. Este problema, em geral, está associado as decisões do dia-a-dia do chão de fábrica (decisões operacionais). Quando acoplado ao problema de dimensionamento de lotes, as decisões de sequenciamento tornam-se relevantes e pode influenciar de forma importante os resultados obtidos no dimensionamento de lotes. Isto pode ocorrer devido a preparações de máquina dependentes da sequência ou ainda por causa de outras características do problema. No problema aqui abordado, por exemplo, os múltiplos níveis de produção associados as necessidades de controle contínuo dos estoques intermediários motivam a resolução integrada destes dois problemas.

Drexl e Kimms (1997) descreveram modelos matemáticos da literatura para o problema integrado de planejamento e sequenciamento da produção. Nesta revisão, foram descritas as seguintes formulações matemáticas para os seguintes problemas com um nível produtivo:

- CLSP (the capacitated lot sizing problem)

O CLSP é um problema de dimensionamento de lotes com múltiplos itens e limitação na capacidade. Observe que, no decorrer desta tese, produtos, itens e gramaturas são utilizados como sinônimos. Neste tipo de modelo não são consideradas decisões de sequenciamento da produção e vários itens podem ser produzidos em um mesmo período.

- DLSP (the discrete lot sizing and scheduling problem)

O DLSP é um problema que considera a integração dos problemas de dimensionamento e sequenciamento de lotes com base em uma grade fixa de tempo. Neste caso, o horizonte de planejamento é dividido em pequenos períodos de tempo. Somente um item pode ser produzido em cada um destes períodos, e quando algum item for produzido, ele deve ocupar toda a capacidade do período (all-or-nothing). A sequência de produção é conhecida a partir dos itens produzidos em cada período.

- CSLP (the continuous setup lot sizing problem)

O CSLP é um problema mais flexível que o DLSP, pois não existe a obrigação de uso completo da capacidade dos períodos. No caso do CSLP a capacidade não precisa ser esgotada, no entanto, a restrição de produção máxima de um item foi mantida.

- PLSP (the proportional lot sizing and scheduling problem)

O PLSP é ainda mais flexível que o CSLP, pois possibilita que até dois tipos de itens sejam produzidos em um mesmo período. Neste caso, apenas uma troca de 
produção é feita por período e o item que é produzido no final de um período continua sendo produzido no período seguinte. Com esta política, fica fácil definir a sequência de produção a partir das trocas de produção feitas durante o horizonte de planejamento.

- GLSP (the general lot sizing and scheduling problem)

No GLSP são definidas duas estruturas de tempo. A primeira é denominada período e tem tamanho fixo, onde são atendidas as demandas e contabilizados estoques e atrasos. A segunda estrutura é denominada micro-período e tem tamanho variável, decidido pelo modelo matemático durante sua resolução. Cada período tem seu conjunto de micro-períodos e a soma das capacidade dos micro-períodos são limitadas pela capacidade do período, ou seja, a soma das capacidades dos micro-períodos deve ser menor ou igual a capacidade do período ao qual pertencem.

- $\mathrm{BSP}$ (the batching and scheduling problem)

o BSP é um modelo de planejamento da produção que trata o horizonte de planejamento de forma contínua. Neste caso a produção é definida em bateladas, que são tratados com tarefas a seres sequenciadas. O problema consiste em sequenciar estas tarefas de forma que elas terminem antes do prazo final, que é o período de entrega da demanda. Além disso, não pode haver sobreposição na produção das bateladas e todas as tarefas devem ser cumpridas a tempo.

No caso dos problemas com múltiplos níveis, Drexl e Kimms (1997) descreveram que os poucos trabalhos que tratavam os problemas de forma integrada até a década de 1990, sendo que os trabalhos descritos utilizavam-se de modelos multi-nível baseados em PLSP.

Zhu e Wilhelm (2006) desenvolveram uma revisão com foco sobre o sequenciamento da produção, onde são considerados meios de produção dos tipos flow shop e job shop (flow shop e job shop são designações dadas a estruturas de produção que definem a sequência na qual os itens percorrem a linha de produção). Além disso, os autores dividem os trabalhos que consideram ou não a integração com o problema de dimensionamento de lotes, o tipo de método de solução e a configuração de máquinas abordada (uma ou múltiplas).

Jans e Degraeve (2008) apresentaram uma revisão com foco em modelos de planejamento e sequenciamento da produção aplicados à indústria. Os autores classificam os trabalhos por quantidade de máquinas, tipos de horizonte de planejamento, perfis de demanda, extensões na preparação das máquinas, características dos estoques e níveis de detalhamento do plano produtivo. Os autores indicam como propostas para pesquisas 
futuras algumas extensões baseadas em necessidades industriais, que vão desde a consideração de máquinas paralelas até a aplicação de teoria de filas para o controle de níveis de estoque em ambientes com incertezas. Apontam também oportunidades de desenvolvimento de métodos que possam tratar estes problemas, como por exemplo, decomposição Dantiz-Wolfe, relaxação lagrangiana e método branch-and-price.

Guimarães et al. (2014) propuseram uma estrutura (framework) de classificação para problemas integrados de planejamento e sequenciamento da produção e discutem modelagens existentes. A classificação é feita quanto o orientação do problema (orientado a produto e orientado a processo), divisão de períodos (macro-períodos e micro-períodos) e a quantidade de lotes de produção (um ou múltiplos lotes) no caso de divisão por macro-períodos. Além da classificação dos variados modelos de planejamento e sequenciamento da produção existentes, também propuseram um novo modelo para o caso de macro-período com múltiplos lotes, baseado no problema de fluxo de produtos SCF (Single Commodity Flow), e apresentam uma série de resultados computacionais que visam comparar qualidade das soluções e limitantes fornecidos pelos modelos. Os autores propõem como possíveis pesquisas futuras, maior atenção em relação a adaptação de modelos e métodos vindos da área de transportes, como o problema do caixeiro viajante assimétrico (ATSP), adaptação dos modelos para atender aspectos industriais práticos e estudos para adaptar os modelos analisados em práticas de planejamento em horizonte rolante.

Trabalhos recentes têm desenvolvido e apresentado modelos matemáticos para resolver problemas de planejamento e sequenciamento da produção nas mais variadas áreas industriais como, por exemplo: produção de alimentos para nutrição animal (TOSO et al., 2009; CLARK et al., 2010), fundição de peças (ARAUJO et al., 2008; CAMARGO et al., 2012), produção de grãos eletro fundidos (LUCHE et al., 2009), produção e envase de refrigerantes (FERREIRA et al., 2009, 2010, 2012; TOLEDO et al., 2014), produção e envase de cerveja (BALDO et al., 2014), indústria de fiação (CAMARGO et al., 2014), e produção de papel e celulose (SANTOS; ALMADA-LOBO, 2012; FIGUEIRA et al., 2013).

Muitos destes trabalhos se assemelham com o problema aqui abordado, pois consideram múltiplos níveis de planejamento e sequenciamento da produção, como na produção e envase de refrigerantes e na indústria de fiação. No entanto, os problemas diferenciamse por características mais específicas de cada planta e processo industrial, o que gera a necessidade de construção de modelos que sejam específicos ao ponto de caracterizar e representar apropriadamente o setor industrial que está sendo tratado. 


\subsection{Modelo matemático de Santos e Almada-Lobo (2012)}

O modelo matemático proposto por Santos e Almada-Lobo (2012) foi desenvolvido com base no GLSPST (General Lotsizing and scheduling problem with sequence-dependent setup times) de Meyr (2000). O GLSP foi inicialmente proposto em Fleischmann e Meyr (1997) e posteriormente, estendido para atender preparações de máquinas dependentes da sequência de produção em Meyr (2000). Dado que esta característica se apresenta no setor produtivo de papel e celulose, Santos e Almada-Lobo (2012) optaram por se basear no GLSPST.

Como apresentado na Seção 2.5, o problema tratado por Santos e Almada-Lobo (2012) corresponde a uma linha produtiva composta por: um digestor, que trabalha de forma contínua; uma máquina de papel, que atende a demanda agregada por tipo de papel; uma linha de recuperação química (planta de energia), composta por um evaporador, e uma caldeira de recuperação; além de tanques de estoque intermediário utilizados como reserva de recursos entre as unidades produtivas da empresa. A Figura 4 apresenta uma ilustração da planta produtiva considerada por Santos e Almada-Lobo (2012).

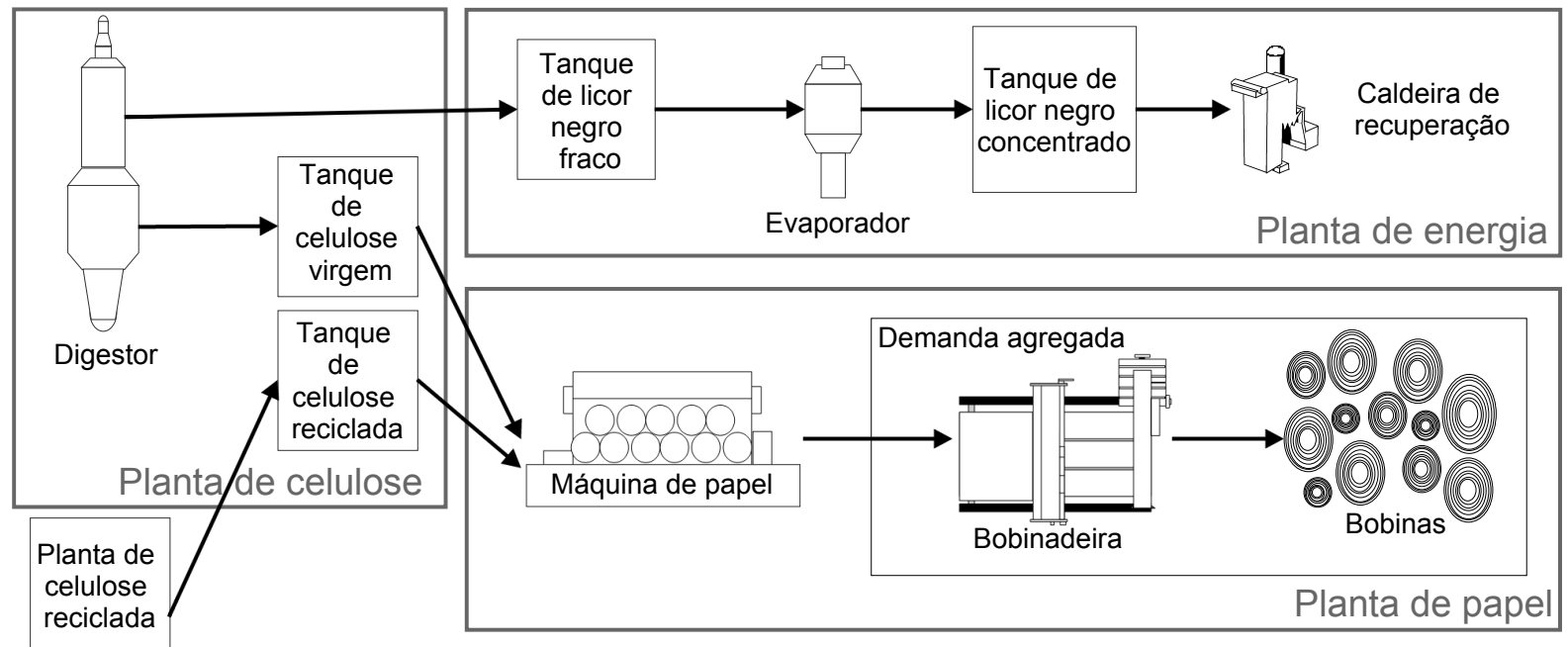

Figura 4: Ilustração do problema abordado em Santos e Almada-Lobo (2012). Fonte: Adaptado de Santos e Almada-Lobo (2012).

Em Santos e Almada-Lobo (2012) foram consideradas algumas suposições e simplificações sobre o processo produtivo, para que fosse possível o desenvolvimento de formulação matemática linear inteira mista. Dentre eles, consideraram como relevantes as seguintes:

1. O horizonte de planejamento foi divididos em períodos que correspondem a um dia cada. Cada período foi dividido em três ou quatro micro-períodos (turnos de 
trabalho) de tamanho variável, como definido no GLSP de Fleischmann e Meyr (1997).

2. A velocidade de trabalho do digestor foi discretizada em $V$ valores, uniformemente distribuídos entre as velocidades mínima e máxima de trabalho. Isto foi feito para assegurar a suavização durante as trocas de velocidade ao longo do horizonte de planejamento. Como suavização, entende-se que a diferença entre velocidades de micro-períodos adjacentes não pode ultrapassar limites estipulados pelo fabricante a fim de manter a estabilidade do equipamento.

3. Os tanques de armazenamento de produtos intermediários tem limites mínimos e máximos nas quantidades estocadas, que garantem que haverá uma pressão mínima no fluxo de saída (estoque mínimo) e que não haverá excesso de material (estoque máximo).

4. A máquina de papel produz um item por vez e as trocas na preparação para produção de itens diferentes geram perdas com tempo de máquina e matéria-prima (celulose), pois o equipamento não é parado durante as mesmas.

5. Não são admitidos tempos ociosos de produção no digestor e na máquina de papel, pois estes dois equipamentos são parados apenas em casos especiais (quebras e manutenções programadas). Desta forma, toda a capacidade produtiva em horas de trabalho devem ser consumidas.

6. Foi considerada a mistura de celulose reciclada para a produção dos itens finais. Para a produção desta celulose, foi considerada uma fábrica associada, com taxas mínima e máxima de produção por hora.

7. Os tipos de papéis são definidos pelas suas gramaturas e pelos percentuais de celulose reciclada adicionadas as misturas que as produzem.

8. Existe a necessidade de produção de lotes mínimos a cada micro-período e somente são permitidas mudanças na velocidade do digestor quanto ocorrer uma troca na produção da máquina de papel.

9. O tamanho dos micro-períodos (em horas) é sincronizado entre todas as unidades produtivas, ou seja, o número de horas da máquina de papel para cada microperíodo será igual a mesma quantidade de horas para o digestor. O mesmo vale para o evaporador e a caldeira de recuperação química. A sincronização facilita o cálculo de níveis dos estoques intermediários, pois uma taxa de consumo/produção 
pode ser considerada constante no decorrer de cada micro-período, exigindo um controle de estoque minucioso apenas nas extremidades dos mesmos.

Para facilitar o entendimento, considere a divisão apresentada na ilustração da Figura 4, na qual a fábrica é dividida em três plantas produtivas, similarmente à Figura 3: planta de celulose, planta de papel e planta de recuperação (ou energia). A apresentação do modelo seguirá a divisão por plantas. Considere os dados e variáveis de decisão apresentados na Tabela 2, que serão utilizados nas três plantas de produção.

Tabela 2: Dados e variáveis utilizados nas três plantas produtivas.

\begin{tabular}{|c|c|}
\hline \multicolumn{2}{|l|}{ Dados } \\
\hline$T$ & $\begin{array}{l}\text { Conjunto de períodos que compõe o horizonte de planejamento } \\
\text { (em dias). }\end{array}$ \\
\hline$S$ & $\begin{array}{l}\text { Conjunto de micro-períodos que compõe o horizonte de planeja- } \\
\text { mento. }\end{array}$ \\
\hline$S_{t}$ & Conjunto de micro-períodos pertencentes ao período $t$. \\
\hline $\operatorname{cap}_{t}$ & Capacidade do período $t$ (em horas). \\
\hline \multicolumn{2}{|c|}{ Variáveis de decisão } \\
\hline$N_{s} \geq 0$ & Tamanho do micro-período $s$ (em horas). \\
\hline
\end{tabular}

\section{Planta de celulose}

A planta de celulose é responsável pelo controle da produção de celuloses virgem e reciclada. Além disso, foi considerado que está planta é responsável pelo controle de estoque das mesmas. As restrições (3.1)-(3.12) a seguir fazem o controle do processo produtivo na planta de celulose, considerando os dados e variáveis apresentados na Tabela 3.

$$
\begin{aligned}
& \sum_{v=1}^{V} Y_{v s}^{d i g}=1, s \in S, \\
& Y_{v s}^{d i g} \leq \sum_{k=(v-\Delta \cdot \Phi)}^{v+\Delta \cdot \Phi} Y_{k, s-1}^{d i g}, v \in V, s \in S, \\
& N h_{v s} \leq c a p_{t} \cdot Y_{v s}^{d i g}, v \in V, t \in T, s \in S_{t}, \\
& N_{s}=\sum_{v \in V} N h_{v s}, s \in S, \\
& \sum_{s \in S_{t}} N_{s}=\operatorname{cap}_{t}, t \in T,
\end{aligned}
$$


Tabela 3: Dados e variáveis relacionados a planta de celulose.

\begin{tabular}{|c|c|}
\hline \multicolumn{2}{|l|}{ Dados } \\
\hline $\bar{V}$ & $\begin{array}{l}\text { Conjunto de velocidades do digestor, que é proporcional a } \\
\frac{v_{m a x}^{d i g}-v_{\min }^{\text {dig }}}{\Phi \cdot \Delta}+1 \text {. }\end{array}$ \\
\hline$\Phi$ & $\begin{array}{l}\text { Passo de discretização da velocidade do digestor (em rotações por } \\
\text { minuto - RPM). }\end{array}$ \\
\hline$\Delta$ & $\begin{array}{l}\text { Variação máxima na velocidade do digestor entre micro-períodos } \\
\text { adjacentes (em passos da discretização). }\end{array}$ \\
\hline$v_{\max }^{\operatorname{dig}}\left(v_{\min }^{\operatorname{dig}}\right)$ & Velocidade máxima (mínima) de trabalho do digestor (em RPM). \\
\hline$s p_{v}$ & Velocidade do digestor no passo de discretização $v$ (em RPM). \\
\hline$\alpha$ & $\begin{array}{l}\text { Taxa de produção de celulose virgem (em toneladas por RPM e } \\
\text { hora). }\end{array}$ \\
\hline$Y_{v, 0}^{d i g}$ & $\begin{array}{l}\text { Velocidade inicial do digestor }\left(Y_{v, 0}^{d i g}=1 \text {, se o digestor inicia o }\right. \\
\text { horizonte de planejamento com a velocidade } v ; Y_{v, 0}^{d i g}=0 \text {, caso } \\
\text { contrário }) \text {. }\end{array}$ \\
\hline$x r_{\max }^{r e c y}\left(x r_{\min }^{r e c y}\right)$ & $\begin{array}{l}\text { Taxa máxima (mínima) de produção da planta de celulose reci- } \\
\text { clada (em toneladas por hora). }\end{array}$ \\
\hline$I_{0}^{v i r g}\left(I_{0}^{r e c y}\right)$ & $\begin{array}{l}\text { Nível inicial do estoque de celulose virgem (reciclada) (em tone- } \\
\text { ladas). }\end{array}$ \\
\hline$I_{\max }^{v i r g}\left(I_{\min }^{v i r g}\right)$ & $\begin{array}{l}\text { Nível máximo (mínimo) do estoque de celulose virgem (em tone- } \\
\text { ladas). }\end{array}$ \\
\hline$I_{\max }^{r e c y}\left(I_{\min }^{r e c y}\right)$ & $\begin{array}{l}\text { Nível máximo (mínimo) do estoque de celulose reciclada (em to- } \\
\text { neladas). }\end{array}$ \\
\hline
\end{tabular}

Variáveis de decisão

$\overline{Y_{v s}^{d i g} \in\{0,1\} \quad \text { Velocidade do digestor no micro-período } s\left(Y_{v s}^{d i g}=1 \text {, se o digestor }\right.}$ trabalha na velocidade $v$ no micro-período $s ; Y_{v s}^{\text {dig }}=0$, caso contrário).

$N h_{v s} \geq 0 \quad$ Quantidade de horas que o digestor trabalha na velocidade $v$ no micro-período $s$.

$X_{s}^{d i g} \geq 0 \quad$ Quantidade de celulose virgem produzida no micro-período $s$.

$X_{s}^{\text {recy }} \geq 0 \quad$ Quantidade de celulose reciclada produzida no micro-período $s$.

$I_{s}^{\text {virg }} \geq 0\left(I_{s}^{\text {recy }} \geq 0\right) \quad$ Nível de estoque de celulose virgem (reciclada) no final do microperíodo $s$ (em toneladas).

$O_{s}^{\text {virg }} \geq 0\left(O_{s}^{\text {recy }} \geq 0\right)$ Quantidade de celulose virgem (reciclada) consumida no microperíodo $s$ (em toneladas).

$I S_{s}^{r e c y} \quad$ Quantidade da mistura de celuloses perdida na preparação de máquina que retorna para o tanque de celulose reciclada para ser reutilizada (em toneladas).

$$
\begin{aligned}
& X_{s}^{\text {dig }}=\alpha \cdot \sum_{v \in V} s p_{v} \cdot N h_{v s}, s \in S, \\
& X_{s}^{r e c y} \geq x r_{\min }^{r e c y} \cdot N_{s}, s \in S, \\
& X_{s}^{r e c y} \leq x r_{\text {max }}^{r e c y} \cdot N_{s}, \quad s \in S,
\end{aligned}
$$




$$
\begin{aligned}
& X_{s}^{\text {dig }}+I_{s-1}^{v i r g}=O_{s}^{v i r g}+I_{s}^{v i r g}, s \in S, \\
& X_{s}^{r e c y}+I_{s-1}^{r e c y}+I S_{s}^{r e c y}=O_{s}^{r e c y}+I_{s}^{r e c y}, s \in S, \\
& I_{m i n}^{\text {virg }} \leq I_{s}^{\text {virg }} \leq I_{m a x}^{v i r g}, \quad s \in S, \\
& I_{m i n}^{\text {recy }} \leq I_{s}^{\text {recy }} \leq I_{\text {max }}^{\text {recy }}, \quad s \in S .
\end{aligned}
$$

As restrições (3.1) garantem que apenas uma velocidade de trabalho do digestor será escolhida por micro-período. As restrições (3.2) garantem a suavização na troca de velocidades do digestor e as restrições (3.3) associam as velocidades aos tempos de trabalho em cada velocidade, possibilitando que apenas as velocidades selecionadas possam ter tempos positivos. O tempo de permanência na velocidade de trabalho é igualado ao tamanho do micro-período nas restrições (3.4), o que garante que não haverá tempo ocioso no digestor quando associado as restrições (3.5). Estas últimas garantem que a soma do tamanho dos micro-períodos pertencentes a cada período serão iguais as capacidades dos respectivos períodos. Nas restrições (3.6) são computadas as quantidades de celulose virgem produzidas. As restrições (3.7) e (3.8) definem os limites mínimo e máximo de capacidade produtiva da fábrica de celulose reciclada por micro-período. O balanço dos estoques de celulose virgem e reciclada são feitos em (3.9) e (3.10), respectivamente. Finalmente, os níveis de estoque mínimo e máximo das duas celuloses são garantidos pelas restrições (3.11) e (3.12).

\section{Planta de papel}

A planta de papel tem como principal tarefa fazer a mistura das celuloses de forma a produzir itens finais que atendam as demandas dos clientes. Nesta planta é feito o dimensionamento e sequenciamento da produção na máquina de papel, que deve levar em consideração as características da linha de produção, bem como seus limites produtivos. As restrições (3.13) - (3.22) são responsáveis pelo controle da produção de papel. Para tal, considere os dados e variáveis de decisão apresentados na Tabela 4.

$$
\begin{aligned}
& \sum_{j \in K} b_{j}^{v i r g} \cdot\left(f_{j} \cdot X_{j s}+\sum_{k \in K} s l_{k j} \cdot Z_{k j s}\right)=O_{s}^{v i r g}, s \in S, \\
& \sum_{j \in K}\left(1-b_{j}^{v i r g}\right) \cdot\left(f_{j} \cdot X_{j s}+\sum_{k \in K} s l_{k j} \cdot Z_{k j s}\right)=O_{s}^{r e c y}, s \in S, \\
& \sum_{j, k \in K} s l_{k j} \cdot Z_{k j s}=I S_{s}^{r e c y}, s \in S
\end{aligned}
$$


Tabela 4: Dados e variáveis relacionados a planta de papel.

\begin{tabular}{|c|c|}
\hline \multicolumn{2}{|l|}{ Dados } \\
\hline$K$ & Conjunto de tipos de papel (gramaturas) produzidos. \\
\hline$s l_{k j}$ & $\begin{array}{l}\text { Perda de matéria-prima durante a troca de produção da gramatura } k \\
\text { para a gramatura } j \text { (em toneladas). }\end{array}$ \\
\hline$s t_{k j}$ & $\begin{array}{l}\text { Perda de capacidade produtiva durante a troca de produção da grama- } \\
\text { tura } k \text { para a gramatura } j \text { (em horas). }\end{array}$ \\
\hline$b_{j}^{v i r g}\left(1-b_{j}^{v i r g}\right)$ & $\begin{array}{l}\text { Porcentagem de celulose virgem (reciclada) utilizada na produção da } \\
\text { gramatura } j \text {. }\end{array}$ \\
\hline$f j$ & Incorporação de água a mistura para a produção da gramatura $j$. \\
\hline & Tempo de processamento da gramatura $j$ (em horas por tonelada). \\
\hline$G_{j}$ & Lote máximo de produção da gramatura $j$ (em toneladas). \\
\hline & Lote mínimo de produção da gramatura $j$ (em toneladas). \\
\hline$D_{j t}$ & Demanda agregada da gramatura $j$ no período $t$ (em toneladas). \\
\hline & Perda média estimada com corte (em porcentagem). \\
\hline$I G_{j 0}^{+}\left(I G_{j 0}^{-}\right)$ & Nível inicial de estoque (atraso) da gramatura $j$ (em toneladas). \\
\hline$Y_{j 0}$ & $\begin{array}{l}\text { Configuração inicial de preparação da máquina de papel }\left(Y_{j 0}=1 \text {, se a }\right. \\
\text { máquina de papel esta prepara para produzir a gramatura } j \text { no início do } \\
\text { horizonte de planejamento; } Y_{j 0}=0 \text {, caso contrário). }\end{array}$ \\
\hline \multicolumn{2}{|c|}{ Variáveis de decisão } \\
\hline$Z_{k j s} \in\{0,1\}$ & $\begin{array}{l}\text { Trocas de preparação na máquina de papel }\left(Z_{k j s}=1 \text {, se houver troca }\right. \\
\text { de preparação da gramatura } k \text { para a gramatura } j \text { no micro-período } s \text {; } \\
Z_{k j s}=0 \text {, caso contrário). }\end{array}$ \\
\hline$Y_{j s} \in\{0,1\}$ & $\begin{array}{l}\text { Preparação da máquina de papel }\left(Y_{j s}=1 \text {, se a máquina de papel esta }\right. \\
\text { preparada para produzir a gramatura } j \text { no micro-período } s ; Y_{j s}=0 \text {, } \\
\text { caso contrário). }\end{array}$ \\
\hline$X_{j s} \geq 0$ & $\begin{array}{l}\text { Quantidade da gramatura } j \text { produzida no micro-período } s \text { (em tonela- } \\
\text { das). }\end{array}$ \\
\hline$I G_{j t}^{+} \geq 0$ & Nível de estoque da gramatura $j$ no final do período $t$ (em toneladas). \\
\hline$I G_{j t}^{-} \geq 0$ & $\begin{array}{l}\text { Nível de atraso na entrega da gramatura } j \text { no final do período } t \text { (em } \\
\text { toneladas). }\end{array}$ \\
\hline
\end{tabular}

$$
\begin{aligned}
& \sum_{j \in K}\left(b_{j} \cdot X_{j s}+\sum_{k \in K} s t_{k j} \cdot Z_{k j s}\right)=N_{s}, s \in S, \\
& (1-\iota) \cdot \sum_{s \in S_{t}} X_{j s}+I G_{j, t-1}^{+}-I G_{j, t-1}^{-}=D_{j t}+I G_{j t}^{+}-I G_{j t}^{-}, j \in K, t \in T, \\
& X_{j s} \leq G_{j} \cdot Y_{j s}, j \in K, s \in S, \\
& X_{j s} \geq m_{j} \cdot Y_{j s}, j \in K, s \in S, \\
& \sum_{j \in K} Y_{j s} \leq 1, s \in S, \\
& Z_{k j s} \geq Y_{k, s-1}+Y_{j s}-1, j, k \in K, s \in S,
\end{aligned}
$$




$$
\left|Y_{v s}^{d i g}-Y_{v, s-1}^{d i g}\right| \leq \sum_{\substack{j, k \in K, k \neq j}} Z_{k j s}, v \in V, s \in S
$$

As restrições (3.13) e (3.14) contabilizam os consumos de celulose virgem e reciclada, respectivamente. O retorno da matéria-prima perdida durante a preparação de máquina como celulose reciclada é computado nas restrições (3.15). As restrições (3.16) garantem que toda a capacidade da máquina de papel em horas será consumida sem sobra ou excesso e que este valor será igual ao utilizado nas demais unidades críticas. O balanceamento de estoque dos itens finais são feitos pela restrições (3.17) e a produção é limitada por tamanhos de lotes mínimos e máximos nas restrições (3.18) e (3.19). As restrições (3.20) garantem que no máximo um item será produzido por micro-período. As restrições (3.21) contabilizam as trocas de produção e, finalmente, as restrições (3.22) sincronizam parcialmente as trocas de velocidade do digestor e as trocas de produção na máquina de papel. Uma troca na velocidade do digestor força a troca de produção na máquina de papel. Da mesma forma, a manutenção da produção na máquina de papel, impossibilita a troca de velocidades no digestor.

\section{Planta de energia}

A planta de energia é responsável pelo tratamento do resíduo de produção chamado licor negro. Por este motivo ela também pode ser nomeada como planta de recuperação química. O tratamento do licor negro fraco tem início com o processo de concentração do resíduo no evaporador, que aumenta seu poder calorífero. Este licor negro concentrado é posteriormente queimado na caldeira de recuperação química, onde é produzido vapor e resíduo sólido. O vapor é utilizado no decorrer do processo produtivo de papel e seu excedente pode ser utilizado para produzir energia elétrica em turbinas associadas. O resíduo sólido, chamado de lima verde, passa por processos adicionais nos quais são extraídos produtos químicos que retornam ao processo de cozimento (no digestor), reduzindo custos com insumo e impactos ambientais. As restrições (3.23) - (3.32) são responsáveis pelo controle da linha de recuperação química até a caldeira de recuperação. Os dados e variáveis de decisão utilizados nestas restrições são apresentados na Tabela 5.

$$
\begin{aligned}
& X_{s}^{\text {liquor }}=\rho \cdot \sum_{v \in V} s p_{v} \cdot N h_{v s}, s \in S, \\
& X_{s}^{\text {liquor }}+I_{s-1}^{\text {liquor }}=O_{s}^{\text {liquor }}+I_{s}^{\text {liquor }}, s \in S,
\end{aligned}
$$


Tabela 5: Dados e variáveis relacionados a planta de energia.

\begin{tabular}{|c|c|}
\hline \multicolumn{2}{|l|}{ Dados } \\
\hline$\rho$ & Taxa de produção de licor negro fraco (em $m_{3}$ por RPM e hora). \\
\hline$\beta$ & $\begin{array}{l}\text { Fator de conversão na transformação de licor negro fraco em licor negro } \\
\text { concentrado. }\end{array}$ \\
\hline$\sigma$ & Fator de conversão de licor negro concentrado em vapor. \\
\hline$C^{e v a p}$ & $\begin{array}{l}\text { Limite de capacidade de consumo de licor negro fraco pelo evaporador } \\
\text { (em } m^{3} \text { por hora). }\end{array}$ \\
\hline$C_{r . b o i l e r}^{\text {burn }}$ & $\begin{array}{l}\text { Limite de capacidade de queima da caldeira de recuperação química (em } \\
m^{3} \text { por hora). }\end{array}$ \\
\hline$C_{r . b o i l e r}^{\text {steam }}$ & $\begin{array}{l}\text { Limite de capacidade de produção de vapor da caldeira de recuperação } \\
\text { química (em } m^{3} \text { por hora). }\end{array}$ \\
\hline$I_{0}^{l i q u o r}$ & Nível de estoque inicial de licor negro fraco $\left(\mathrm{em} \mathrm{m}^{3}\right)$. \\
\hline$I_{\max }^{\text {liquor }}\left(I_{\text {min }}^{\text {liquor }}\right)$ & Limite máximo (mínimo) de estoque de licor negro fraco $\left(\mathrm{em} \mathrm{m}^{3}\right)$. \\
\hline$I_{0}^{c . l i q}$ & Nível de estoque inicial de licor negro concentrado $\left(\mathrm{em}^{3}\right)$. \\
\hline$I_{\max }^{c . l i q}\left(I_{\min }^{c . l i q}\right)$ & Limite máximo (mínimo) de estoque de licor negro concentrado (em $\mathrm{m}^{3}$ ). \\
\hline \multicolumn{2}{|c|}{ Variáveis de decisão } \\
\hline$X_{s}^{\text {liquor }} \geq 0$ & Quantidade de licor negro fraco produzido no micr \\
\hline$I_{s}^{\text {liquor }} \geq 0$ & Nível de estoque de licor negro fraco no final do micro-período $s$. \\
\hline$O_{s}^{\text {liquor }} \geq 0$ & $\begin{array}{l}\text { Quantidade de licor negro fraco consumido pelo evaporador durante o } \\
\text { micro-período } s \text {. }\end{array}$ \\
\hline$X_{s}^{c . l i q} \geq 0$ & Quantidade de licor negro concentrado produzido no micro-período $s$. \\
\hline$I_{s}^{\text {c.liq }} \geq 0$ & Nível de estoque de licor negro concentrado no final do micro-período $s$. \\
\hline$O_{s}^{\text {c.liq }} \geq 0$ & $\begin{array}{l}\text { Quantidade de licor negro concentrado consumido pela caldeira de recu- } \\
\text { peração química durante o micro-período } s \text {. }\end{array}$ \\
\hline$O_{s}^{\text {steam }} \geq 0$ & Quantidade de vapor produzido no micro-período $s$. \\
\hline
\end{tabular}

$$
\begin{aligned}
& I_{\text {min }}^{\text {liquor }} \leq I_{s}^{\text {liquor }} \leq I_{\max }^{\text {liquor }}, s \in S, \\
& 0 \leq O_{s}^{\text {liquor }} \leq C^{\text {evap }} \cdot N_{s}, s \in S, \\
& X_{s}^{c . l i q}=\beta \cdot O_{s}^{l i q u o r}, s \in S \text {, } \\
& X_{s}^{c . l i q}+I_{s-1}^{c . l i q}=O_{s}^{c . l i q}+I_{s}^{c . l i q}, s \in S, \\
& I_{\text {min }}^{\text {cliq }} \leq I_{s}^{c . l i q} \leq I_{\text {max }}^{c . l i q}, s \in S, \\
& O_{s}^{\text {cliq }} \leq C_{r . b o i l e r}^{\text {burn }} \cdot N_{s}, s \in S, \\
& O_{s}^{\text {steam }}=\sigma \cdot O_{s}^{\text {c.liq }}, s \in S, \\
& O_{s}^{\text {steam }} \leq C_{r . \text { boiler }}^{\text {steam }} \cdot N_{s}, s \in S .
\end{aligned}
$$

As restrições (3.23) contabilizam as quantidades de licor negro fraco produzidas durante cada micro-período $s$ do horizonte de planejamento. As restrições (3.26) limitam o consumo de licor negro fraco pelo limite de capacidade do evaporador e as restrições 
(3.27) contabilizam as quantidades de licor negro concentrado produzidas. Os limites de capacidade da caldeira de recuperação são garantidos nas restrições (3.30) e (3.32), sendo que o primeiro grupo é responsável por limitar a queima e o segundo limita a produção de vapor. As quantidades produzidas de vapor são determinadas pelas restrições (3.31). As restrições (3.24) e (3.28) fazem os balanços de estoque de licor negro fraco e concentrado, respectivamente, e os limites de capacidade dos estoques intermediário são garantidos pelas restrições $(3.25)$ e (3.29).

\section{Função objetivo}

A função objetivo contém os principais custos de produção, sendo eles custos de estoques, custos de atraso nas entregas e custos de preparações de máquina. A função objetivo utilizada neste modelo foi a seguinte:

$$
\min \sum_{\substack{j \in K \\ t \in T}} \psi_{j t}^{+} \cdot I G_{j t}^{+}+\sum_{\substack{j \in K \\ t \in T}} \psi_{j t}^{-} \cdot I G_{j t}^{-}+\sum_{\substack{j, k \in K \\ s \in S}} \lambda_{k j} \cdot Z_{k j s}-\sum_{s \in S} \vartheta \cdot X_{s}^{d i g}
$$

no qual $\psi_{j t}^{+}$representa o custo de estocagem de uma tonelada da gramatura $j$ durante o período $t, \psi_{j t}^{-}$é o custo unitário de atraso na entrega de uma tonelada da gramatura $j$ durante o período $t$ e $\lambda_{k j}$ que representa o custo de troca na preparação da máquina de papel da gramatura $k$ para a gramatura $j$. Além disso, foi considerado um incentivo a produção de celulose virgem, representado por $\vartheta$.

\subsection{Modelo matemático de Figueira et al. (2013)}

O modelo matemático proposto por Figueira et al. (2013) teve como base a formulação descrita na Seção 3.2. Características foram adicionadas ao modelo como, por exemplo, a definição de ciclos de produção. Além disso, as restrições que contabilizam as trocas de preparação (3.21) foram substituídas por variantes baseadas no problema de redes (restrições (3.38) e (3.39)), que tem relaxação linear mais apertada (para mais informações, ver Karmarkar e Schrage (1985) e Wolsey (2002)). Foi adotado tamanho mínimo de micro-período e foram alteradas as restrições que contabilizam as quantidades de celulose, obtidas a partir das perdas de matéria-prima no processo produtivo do papel (restrições 3.40 e 3.41). Na função objetivo foram adicionadas mais parcelas de incentivo à outras unidades produtivas. Apresentamos a seguir as diferenças entre os modelos de Figueira 
et al. (2013) e Santos e Almada-Lobo (2012).

\section{Planta de celulose}

Foram feitas duas alterações no controle da planta de celulose, quando comparado ao modelo anterior. Foi adicionado um tamanho mínimo de micro-períodos $N_{\min }$ (em horas) que garante que o digestor permaneça uma quantidade mínima de tempo em uma determinada velocidade, antes que possa haver uma mudança na mesma. Além disso, foi considerado um limite adicional na produção de celulose reciclada, que limita a produção agregada do período (dia) a uma porcentagem da capacidade total ( $\left.K_{c a p}^{\text {recy }}\right)$. Desta forma, é permitido que a fábrica de celulose reciclada trabalhe no seu limite produtivo durante algumas horas do dia, mas não possibilita que está o faça durante o dia todo.

\section{Planta de papel}

A planta de papel recebeu o maior número de alterações, devido ao acréscimo dos ciclos de produção. Um ciclo de produção foi definido como um período específico de tempo (em dias) onde são produzidos itens suficientes para atender a demanda em atraso no final do ciclo de produção anterior. Além disso, todos os ciclos tem a mesma gramatura inicial. Apresentamos na Tabela 6 os dados adicionais utilizados. Além disso, o conceito do parâmetro $f_{j}$ foi alterado de incorporação de água a mistura para percentual de incorporação de água a mistura, ou seja, $f_{j}^{\text {novo }}=\left(1-f_{j}^{\text {velho }}\right)$.

Tabela 6: Dados adicionais da planta de papel.

\begin{tabular}{ll}
\hline Dados & \\
\hline$j_{1}$ & $\begin{array}{l}\text { Primeira gramatura produzida em todos os ciclos (comum a todos os } \\
\text { ciclos). }\end{array}$ \\
$C$ & $\begin{array}{l}\text { Quantidade de ciclos existentes no horizonte de planejamento (em perío- } \\
\text { dos), que não precisa ser inteiro. }\end{array}$ \\
$C^{+}$ & Limite superior da quantidade de ciclos $\left(C^{+}=\lceil C\rceil\right)$. \\
$C^{-}$ & Limite inferior da quantidade de ciclos $\left(C^{-}=\lfloor C\rfloor\right)$. \\
$T_{c}$ & Conjunto de períodos pertencentes ao ciclo $c,$. \\
$S_{c y c l e}$ & Conjunto de micro-períodos pertencentes ao ciclo $c$. \\
$t_{1 c}$ & Período inicial do ciclo $c$. \\
$s_{1 c}$ & Micro-período inicial do ciclo $c$.
\end{tabular}

Os ciclos produtivos são modelados das seguintes restrições: 


$$
\begin{gathered}
(1-\iota) \cdot \sum_{s \in S_{\text {cycle }_{c}}} X_{j s} \geq I G_{j, t_{1 c}-1}^{-}, c \in C^{-}, \\
Y_{j_{1}, s_{1 c}}=1, c \in C^{+},
\end{gathered}
$$

nos quais as restrições (3.34) obrigam o atendimento das demandas atrasadas no final do ciclo de produção anterior e as restrições (3.35) fixam a primeira gramatura de cada ciclo como sendo igual a gramatura $j_{1}$. As restrições (3.13) e (3.14), responsáveis pela contabilização dos consumos de celulose virgem e reciclada, foram reescritas da seguinte forma:

$$
\begin{array}{r}
\sum_{j \in K} b_{j}^{v i r g} \cdot\left(1-f_{j}\right) \cdot\left(X_{j s}+\sum_{k \in K} s l_{k j} \cdot Z_{k j s}\right)=O_{s}^{v i r g}, s \in S, \\
\sum_{j \in K}\left(1-b_{j}^{v i r g}\right) \cdot\left(1-f_{j}\right) \cdot\left(X_{j s}+\sum_{k \in K} s l_{k j} \cdot Z_{k j s}\right)=O_{s}^{r e c y}, s \in S .
\end{array}
$$

As restrições (3.21), responsáveis pela contabilização das trocas de preparação, foram substituídas pelas variações baseadas em fluxo de redes, definidas da seguinte maneira:

$$
\begin{aligned}
& \sum_{j \in K} Z_{k j s}=Y_{k, s-1}, k \in K, s \in S, \\
& \sum_{k \in K} Z_{k j s}=Y_{j s}, j \in K, s \in S .
\end{aligned}
$$

Nas restrições de retorno da matéria-prima perdida durante a preparação de máquina (3.15) foram acrescidas as perdas com o processo de corte, que também podem ser reutilizadas. As adaptações foram feitas da seguinte forma:

$$
\sum_{j, k \in K}\left(1-f_{j}\right) \cdot s l_{k j} \cdot Z_{k j s}+\iota \sum_{j \in K} X_{j s}=I S_{s}^{r e c y}, s \in S
$$

Além disso, as restrições de lote mínimo (3.19) foram reescritas para impor que o lote mínimo deve ser cumprido apenas nos micro-períodos onde houver troca na preparação de máquina (troca de produção). A nova restrição é a seguinte: 


$$
X_{j s} \geq m_{j} \cdot\left(Y_{j s}-Y_{j, s-1}\right), j \in K, s \in S
$$

As restrições responsáveis pela sincronização parcial das trocas de preparação de máquina e velocidade do digestor (3.22) foram removidas, possibilitando desta forma que ambos trabalhem de forma mais independente.

\section{Planta de energia}

Na planta de energia foi feita apenas uma mudança no conceito do parâmetro $\rho$, que foi alterado de taxa de produção de licor negro fraco, com relação a velocidade e tempo de produção, para proporção entre as produções de celulose virgem e licor negro fraco. Desta forma, as restrições (3.23), que contabilizam as produções de licor negro fraco, foram reescritas da seguinte maneira:

$$
X_{s}^{\text {liquor }}=\rho \cdot X_{s}^{\text {dig }}, s \in S \text {. }
$$

\section{Função objetivo}

Foram adicionados mais três incentivos à produção na função objetivo, sendo eles: incentivo à produção de vapor, incentivo ao consumo de licor negro fraco e incentivo à produção de celulose reciclada. Além disso, foi utilizada uma abordagem de pesos, onde o tomador de decisão define qual a importância de cada parcela da função objetivo. Os pesos foram definidos segundo a seguinte função:

$$
\lambda_{i}=\frac{w_{i}}{F_{i}^{\max }}
$$

na qual $\lambda_{i}$ representa o peso da $i$-ésima parcela da função objetivo, $w_{i}$ é o peso definido pelo tomador de decisão, $F_{i}^{\text {max }}$ é o valor máximo que a $i$-ésima parcela da função objetivo pode alcançar. A função objetivo foi reescrita da seguinte forma:

$$
\min \sum_{\substack{j \in K \\ t \in T}} \lambda_{1} \cdot I G_{j t}^{+}+\sum_{\substack{j \in K \\ t \in T}} \lambda_{2} \cdot I G_{j t}^{-}+\sum_{\substack{j, k \in K \\ s \in S}} \lambda_{3} \cdot s l_{k j} \cdot Z_{k j s}-\sum_{s \in S} \lambda_{4} \cdot O_{s}^{\text {steam }}
$$




$$
-\sum_{s \in S} \lambda_{5} \cdot O_{s}^{\text {liquor }}-\sum_{s \in S} \lambda_{6} \cdot X_{s}^{\text {recy }}-\sum_{s \in S} \lambda_{7} \cdot X_{s}^{\text {dig }}
$$

\subsection{Modelo matemático proposto}

O modelo matemático proposto nesta tese estende os modelos anteriores com o objetivo de representar e resolver problemas verificados na prática em plantas com múltiplas máquinas de papel. Para isto, foram adaptadas algumas variáveis de decisão e restrições do modelo matemático. Tomando o modelo de Santos e Almada-Lobo (2012) como base, foram feitas as extensões propostas por Meyr (2002), onde o GLSPST foi estendido para tratar problemas com linhas (máquinas) paralelas (GLSPPL). Restrições adicionais para atenuar a dependência entre máquinas foram inseridas, dado a necessidade de sincronização de micro-períodos que possibilitam o controle de estoques intermediários. Além disso, foram desenvolvidos três famílias de restrições que visam agregar algumas práticas comuns na tomada de decisão deste setor industrial. No restante deste documento o modelo GLSPPL será referido apenas como GLSP.

\section{Planta de celulose}

Para modelar as restrições relacionadas com a planta de celulose, considere um conjunto $M$ de máquinas de papel. Considere ainda a modificação das variáveis $O_{s}^{\text {virg }}$ para $O_{s m}^{v i r g}$, que indicam a quantidade (em toneladas) de celulose virgem consumida pela máquina $m$ no micro-período $s$. Foi utilizado o conceito de tamanho mínimo de microperíodo, como em Figueira et al. (2013). Optou-se pela utilização desta estratégia para habilitar micro-períodos muito pequenos ou nulos, sem possibilitar a troca na velocidade do digestor. Como o produto final não utiliza fibra reciclada, todas as restrições de controle de produção relacionadas a esta fibra foram removidas. Vale a pena ressaltar que a reintrodução desta característica é uma tarefa simples e que, desta forma, o modelo proposto pode ser facilmente adaptado para o uso de celulose reciclada, caso a empresa estudada tenha esta característica.

Como as decisões de escolha de velocidades do digestor não influenciam diretamente os custos da função objetivo, não existe uma diferenciação entre soluções com muitas modificações na velocidade e soluções com poucas trocas que alcancem níveis de produção agregada similares. Para indicar uma preferência pelas soluções com menor quantidade de trocas de velocidade, foram adicionadas as restrições (3.45) e (3.46) e definidas as variáveis $\mu_{s}$, que computam se houve troca de velocidade no digestor no início do micro- 
período s. Estas novas variáveis são penalizadas na função objetivo por valores muito pequenos, apenas como critério de desempate, de tal forma que não influenciem na solução do problema com base nos outros critérios. O conjunto completo de restrições responsáveis pelo controle da planta de celulose são as seguintes:

$$
\begin{aligned}
& \mu_{s} \geq Y_{v s}-Y_{v, s-1}, s \in S, \\
& \mu_{s} \geq Y_{v, s-1}-Y_{v s}, s \in S, \\
& \sum_{v=1}^{V} Y_{v s}^{d i g}=1, s \in S, \\
& Y_{v s}^{d i g} \leq \sum_{k=(v-\Delta \cdot \Phi)}^{v+\Delta \cdot \Phi} Y_{k, s-1}^{d i g}, v \in V, s \in S, \\
& N h_{v s} \leq c a p_{t} \cdot Y_{v s}^{d i g}, v \in V, t \in T, s \in S_{t}, \\
& N_{s}=\sum_{v \in V} N h_{v s}, s \in S, \\
& \sum_{s \in S_{t}} N_{s}=c a p_{t}, t \in T, \\
& X_{s}^{\text {dig }}=\alpha \cdot \sum_{v \in V} s p_{v} \cdot N h_{v s}, s \in S, \\
& X_{s}^{l i q u o r}=\rho \cdot \sum_{v \in V} s p_{v} \cdot N h_{v s}, s \in S, \\
& N_{s} \geq N_{m i n} \cdot\left(Y_{v s}^{\text {dig }}-Y_{v, s-1}^{d i g}\right), v \in V, s \in S, \\
& X_{s}^{\text {dig }}+I_{s-1}^{v i r g}=\sum_{m \in M} O_{s m}^{v i r g}+I_{s}^{v i r g}, s \in S, \\
& I_{m i n}^{v i r g} \leq I_{s}^{v i r g} \leq I_{m a x}^{v i r g}, s \in S .
\end{aligned}
$$

As restrições (3.45) e (3.46) fazem a contabilização de trocas de velocidade no digestor. Destas, as restrições (3.45), (3.46), (3.54) e (3.55). As demais restrições são idênticas as apresentadas no modelo de Santos e Almada-Lobo (2012). Todas as vezes que houver troca na velocidade do digestor, a restrição de uma das duas famílias gerará uma restrição do tipo $\mu_{s}>0$. As restrições (3.47) limitam a escolha de velocidade do digestor em exatamente uma velocidade por micro-período. As restrições (3.48) são responsáveis pela suavização na troca de velocidade do digestor e as restrições (3.49) garantem uma correlação entre a escolha da velocidade e os tempos de permanência em cada velocidade. Desta forma, só poderão ter valores de tempo $\left(N h_{v s}\right)$ positivos as velocidades escolhidas em cada micro-período $\left(N h_{v s}>=0 \mid Y_{v s}=1\right)$. As restrições (3.50) fazem a contabili- 
zação dos tamanhos dos micro-períodos $\left(N_{s}\right)$, igualando estes a soma dos tempos usados em cada velocidade, no qual apenas um pode ser positivo em cada micro-período. Como não é permitido tempo ocioso no digestor, a capacidade diária de produção é totalmente distribuída pelos micro-períodos em (3.49). A contabilização das quantidades produzidas de celulose virgem e licor negro fraco são feitas em (3.52) e (3.53), respectivamente. O tamanho mínimo de micro-período é garantido pelas restrições (3.54), em que apenas os períodos com troca na velocidade contam com esta regra. Como são geradas $|V|$ restrições deste tipo para cada micro-período, quando houver troca na velocidade, teremos uma restrição com diferença positiva e outra negativa. Por exemplo, considere a troca da velocidade 10 para 11 no micro-período $\pi$. Neste caso, teremos que $Y_{10, \pi-1}^{d i g}=1$ e $Y_{11, \pi}^{d i g}=1$ e as restrições construídas tomam a seguinte forma:

$$
\begin{aligned}
& N_{s} \geq N_{\min } \cdot\left(Y_{11, \pi}^{d i g}-Y_{11, \pi-1}^{d i g}\right) \\
& N_{s} \geq N_{\min } \cdot(1-0) \\
& N_{s} \geq N_{\min }
\end{aligned}
$$

e, ao mesmo tempo, a contraparte:

$$
\begin{aligned}
& N_{s} \geq N_{\min } \cdot\left(Y_{10, \pi}^{d i g}-Y_{10, \pi-1}^{d i g}\right) \\
& N_{s} \geq N_{\min } \cdot(0-1) \\
& N_{s} \geq-N_{\min }
\end{aligned}
$$

ou seja, o tamanho mínimo de micro-período deve ser respeitado apenas quando há troca na velocidade do digestor. As restrições (3.55) fazem o balanço de estoque da celulose virgem e as restrições (3.56) estipulam os limites mínimos e máximos de estocagem que devem ser respeitados. Assim, as diferenças essenciais do modelo base, além de consideradas múltiplas máquinas, estão nas restrições (3.45), (3.46) e (3.54), para a planta de celulose.

\section{Planta de papel}

A consideração de múltiplas máquinas de papel que trabalham de forma paralela gera a necessidade de modificações mais expressivas nas restrições de controle da planta de 
papel. Adicionalmente ao incremento na quantidade de índices de parâmetros e variáveis de decisão, foram feitas modificações nas restrições de lote mínimo e de tamanho mínimo de micro-período do modelo base. Isso garante que possam ser utilizados micro-períodos nulos quando estes forem vantajosos. Lotes mínimos são exigidos quanto existe troca de produção na máquina de papel. Analogamente, tamanho mínimo de micro-período somente é requerido quando existe troca de velocidade no digestor. Finalmente, as restrições de contabilização de trocas de preparação nas máquinas de papel foram substituídas pelas restrições de fluxo em rede, como apresentado por Figueira et al. (2013). Os dados e variáveis de decisão apresentados na Tabela 7 são utilizados para construção das restrições de controle da planta de papel, apresentadas a seguir.

Tabela 7: Dados e variáveis relacionados a planta de papel com múltiplas máquinas.

\begin{tabular}{|c|c|}
\hline \multicolumn{2}{|l|}{ Dados } \\
\hline$s l_{k j m}$ & $\begin{array}{l}\text { Perda de matéria-prima durante a troca de produção da gramatura } k \\
\text { para a gramatura } j \text { na máquina de papel } m \text { (em toneladas). }\end{array}$ \\
\hline$s t_{k j m}$ & $\begin{array}{l}\text { Perda de capacidade produtiva durante a troca de produção da grama- } \\
\text { tura } k \text { para a gramatura } j \text { na máquina de papel } m \text { (em horas). }\end{array}$ \\
\hline$b_{j m}^{v i r g}$ & $\begin{array}{l}\text { Porcentagem de celulose virgem utilizada na produção da gramatura } j \\
\text { na máquina de papel } m \text {. }\end{array}$ \\
\hline$b_{j m}$ & $\begin{array}{l}\text { Tempo de processamento da gramatura } j \text { na máquina de papel } m \text { (em } \\
\text { horas por tonelada). }\end{array}$ \\
\hline$G_{j m}$ & $\begin{array}{l}\text { Lote máximo de produção da gramatura } j \text { na máquina de papel } m \text { (em } \\
\text { toneladas). }\end{array}$ \\
\hline$m_{j m}$ & $\begin{array}{l}\text { Lote mínimo de produção da gramatura } j \text { na máquina de papel } m \text { (em } \\
\text { toneladas). }\end{array}$ \\
\hline$I G_{j 0}^{+}\left(I G_{j 0}^{-}\right)$ & Nível inicial de estoque (atraso) da gramatura $j$ (em toneladas). \\
\hline$Y_{j 0 m}$ & $\begin{array}{l}\text { Configuração inicial de preparação da máquina de papel }\left(Y_{j 0 m}=1 \text {, se a }\right. \\
\text { máquina de papel } m \text { esta prepara para produzir a gramatura } j \text { no início } \\
\left.\text { do horizonte de planejamento; } Y_{j 0 m}=0 \text {, caso contrário }\right) \text {. }\end{array}$ \\
\hline \multicolumn{2}{|c|}{ Variáveis de decisão } \\
\hline$Z_{k j s m} \in\{0,1\}$ & $\begin{array}{l}\text { Trocas de preparação na máquina de papel }\left(Z_{k j s m}=1 \text {, se houver troca }\right. \\
\text { na preparação da máquina } m \text { da gramatura } k \text { para a gramatura } j \text { no } \\
\left.\text { micro-período } s ; Z_{k j s m}=0 \text {, caso contrário }\right) .\end{array}$ \\
\hline$Y_{j s m} \in\{0,1\}$ & $\begin{array}{l}\text { Preparação da máquina de papel }\left(Y_{j s m}=1 \text {, se a máquina de papel } m\right. \\
\text { esta preparada para produzir a gramatura } j \text { no micro-período } s ; Y_{j s m}=0 \\
\text {, caso contrário). }\end{array}$ \\
\hline$X_{j s m} \geq 0$ & $\begin{array}{l}\text { Quantidade da gramatura } j \text { produzida no micro-período } s \text { na máquina } \\
\text { de papel } m \text { (em toneladas). }\end{array}$ \\
\hline
\end{tabular}




$$
\begin{aligned}
& \sum_{j \in K} b_{j m}^{v i r g} \cdot\left(X_{j s m}+\sum_{k \in K} s l_{k j m} \cdot Z_{k j s m}\right)=O_{s m}^{v i r g}, s \in S, m \in M, \\
& \sum_{j \in K}\left(b_{j m} \cdot X_{j s m}+\sum_{k \in K} s t_{k j m} \cdot Z_{k j s m}\right)=N_{s}, s \in S, m \in M, \\
& \sum_{\substack{s \in S_{t} \\
m \in M}} X_{j s m}+I G_{j, t-1}^{+}-I G_{j, t-1}^{-}=D_{j t}+I G_{j t}^{+}-I G_{j t}^{-}, j \in K, t \in T, \\
& X_{j s m} \leq \min \left\{G_{j m}, \frac{C_{t}}{b_{j m}}\right\} \cdot Y_{j s m}, j \in K, s \in S, m \in M, \\
& X_{j s m} \geq m_{j m} \cdot\left(Y_{j s m}-Y_{j, s-1, m}\right), j \in K, s \in S, m \in M, \\
& \sum_{j \in K} Y_{j s m} \leq 1, s \in S, m \in M, \\
& \sum_{j \in K} Z_{k j s m}=Y_{k, s-1, m}, k \in K, s \in S, m \in M, \\
& \sum_{k \in K} Z_{k j s m}=Y_{j s m}, j \in K, s \in S, m \in M .
\end{aligned}
$$

As restrições (3.57) são responsáveis pelo acoplamento das plantas de celulose e papel, em que contabilizam o consumo de celulose virgem de cada máquina de papel $m$ em cada micro-período $s$. Os tempos de cada micro-período devem ser totalmente consumidos com produção e preparação de máquina, pois não existe tempo ocioso, e são representadas pelas restrições (3.58). O balanceamento de estoque dos itens finais (gramaturas) são feitos pelas restrições (3.59). Neste caso, foi mantido o mesmo padrão dos trabalhos anteriores, com exceção da adição de máquinas paralelas podendo produzir a mesma gramatura. Não foi considerado aqui a alocação de pedido a máquina como em Correia et al. (2012), pois a demanda foi agregada por tipo de papel. No caso da integração do problema de corte, por exemplo, a alocação de máquina poderia ser considerada a fim de evitar que partes de um mesmo produto final sejam feitas em máquinas distintas. Isso não é desejável por dois motivos: os itens finais devem ter uma integridade física, ou seja, uma única bobina que atende a demanda de um cliente não pode ser cortada a partir de mais de um jumbo. Além disso, podem haver alterações nas especificações dos produtos de máquinas distintas, gerando variação nas especificações de itens iguais de um mesmo pedido. Por exemplo, se um cliente compra duas ou mais bobinas de um mesmo papel, é desejável que todas as bobinas tenham especificações mais similares possíveis.

As restrições (3.60) garantem que só haverá produção de uma gramatura $j$ em um micro-período $s$ quando a máquina $m$ estiver preparada para produzi-lo. Neste caso, 
optamos por utilizar o menor valor entre um tamanho de lote máximo (número grande) e a capacidade do período (dia) dividido pela taxa de produção da gramatura, ou seja, quanto poderia ser produzido de uma gramatura se não houvesse preparação de máquina ou outras produções. Os lotes mínimos são requeridos pelas restrições (3.61) quando existe troca na preparação. As restrições (3.62) garantem que haverá no máximo um item sendo produzido por micro-período e máquina, e as restrições (3.63) e (3.64) fazem o controle de troca de preparação nas máquinas de papel. Além do acréscimo de múltiplas máquinas, foram feitas alterações nas restrições (3.60), (3.61), (3.63) e (3.64) da planta de papel.

\section{Planta de recuperação}

Durante as visitas às empresas foi verificado que apenas um dos limites de capacidade produtiva é relevante como gargalo de produção. Segundo os gerentes de produção das empresas, a capacidade da caldeira de recuperação é a responsável por limitar a planta de recuperação. Esta é a unidade produtiva com maior custo para aumento de capacidade com a compra de novos equipamentos, fazendo com que seus recursos devam ser utilizados com maior cuidado. Desta forma, o controle da linha de recuperação pode ser simplificada por meio da remoção das restrições (3.67)-(3.71) e da adaptação da restrição (3.72) para fazer a transformação do licor negro fraco diretamente em vapor (combinar os parâmetros $\beta$ e $\sigma$ em um novo parâmetro $\omega=\beta \cdot \sigma$ ). O controle da planta de recuperação é feito pelas restrições (3.65)-(3.73). Não houveram modificações nas restrições de controle desta planta produtiva, quando comparado as restrições apresentadas por Santos e AlmadaLobo (2012) (Seção 3.2). Apenas as restrições (3.23) foram transferidas para a planta de celulose para deixar mais clara a similaridade com as restrições de produção de celulose (restrições 3.52 e 3.53). As restrições 3.53 são responsáveis pelo acoplamento da planta de celulose com a planta de recuperação química.

$$
\begin{aligned}
X_{s}^{\text {liquor }}+I_{s-1}^{\text {liquor }} & =O_{s}^{\text {liquor }}+I_{s}^{\text {liquor }}, s \in S, \\
I_{\text {min }}^{\text {liquor }} \leq I_{s}^{\text {liquor }} & \leq I_{\text {max }}^{\text {liquor }}, s \in S, \\
0 \leq O_{s}^{\text {liquor }} & \leq C^{\text {evap }} \cdot N_{s}, s \in S, \\
X_{s}^{c . l i q} & =\beta \cdot O_{s}^{\text {liquor }}, s \in S, \\
X_{s}^{\text {c.liq }}+I_{s-1}^{\text {cliq }} & =O_{s}^{\text {c.liq }}+I_{s}^{c . l i q}, s \in S, \\
I_{\text {min }}^{\text {cliq }} \leq I_{s}^{\text {cliq }} & \leq I_{\text {max }}^{\text {clliq }}, s \in S, \\
O_{s}^{c . l i q} & \leq C_{r . \text { boiler }}^{\text {burn }} \cdot N_{s}, \quad s \in S,
\end{aligned}
$$




$$
\begin{aligned}
& O_{s}^{\text {steam }}=\sigma \cdot O_{s}^{\text {c.liq }}, s \in S, \\
& O_{s}^{\text {steam }} \leq C_{\text {steam }}^{\text {r.boiler }} \cdot N_{s}, \quad s \in S .
\end{aligned}
$$

As restrições (3.65) são responsáveis pelo balanceamento de estoque de licor negro fraco e seus limites são estipulados nas restrições (3.66). A capacidade limite de consumo de licor negro fraco pelo evaporador é garantida pelas restrições (3.67) e a quantidade de licor negro concentrado produzido é calculada nas restrições (3.68). As restrições (3.69) fazer o balanceamento de estoque de licor negro concentrado e as restrições (3.70) controlam os limites deste estoque intermediário. O controle da quantidade máxima de queima de licor negro fraco é garantido nas restrições (3.71) e as quantidades de vapor produzidas a partir do licor negro fraco são calculadas nas restrições (3.72). Finalmente, as restrições (3.73) garantem o atendimento do limite de produção de vapor da caldeira.

\section{Função objetivo}

A função objetivo leva em conta os preços médios das gramaturas vendidas a fim de mesclar os múltiplos objetivos em uma única função monetária. Quando comparada a função objetivo utilizada em Santos e Almada-Lobo (2012), foram mantidos os três custos utilizados (estoque, atraso e preparação de máquina). O incentivo a produção de celulose foi substituído pelo incentivo a produção de vapor e, por fim, foi adicionada uma pequena penalização sobre as trocas de velocidade no digestor. A função objetivo utilizada é a seguinte:

$$
\begin{aligned}
& \min \sum_{\substack{j \in K \\
t \in T}} h_{j t}^{+} \cdot I G_{j t}^{+}+\sum_{\substack{j \in K \\
t \in T}} h_{j t}^{-} \cdot I G_{j t}^{-}+\sum_{\substack{j, k \in K \\
s \in S \\
m \in M}} s c_{k j m} \cdot Z_{k j s m}-\sum_{s \in S} \gamma \cdot O_{s}^{s t e a m} \\
& \quad+\sum_{s \in S} \varepsilon \cdot \mu_{s}
\end{aligned}
$$

na qual $h_{j t}^{+}$representa o custo de estocagem de uma tonelada da gramatura $j$ durante o período $t, h_{j t}^{-}$mede o custo de atraso na entrega de uma tonelada da gramatura $j$ no período $t$ e $s c_{k j m}$ define o custo decorrente da troca de produção da gramatura $k$ para a gramatura $j$ na máquina de papel $m$. Note que $\gamma$ é um incentivo a produção de vapor, decorrente da produção de energia elétrica a partir de seu excedente, e $\varepsilon$ indica uma penalização (bem pequena) utilizada para diferenciar soluções de custo igual pela menor quantidade de trocas de velocidade do digestor. 


\subsubsection{Restrições de limitação de itens produzidos}

Uma das práticas verificadas nas empresas visitadas consiste na redução do problema durante o planejamento, que consiste em dividir a demanda de gramaturas previamente entre as máquinas. Por exemplo, se um produto tem demanda consideravelmente superior a dos demais, o seu atendimento será produzido apenas por uma das máquinas. Neste caso, as máquinas restantes são responsáveis pela produção das demais gramaturas. Isto é uma prática simples que pode reduzir a complexidade do problema e custos de preparação de máquina ao mesmo tempo. No entanto, este recurso deve ser utilizado com cuidado, pois pode eliminar soluções de alta qualidade ao reduzir o espaço de busca e tornar o modelo matemático menos flexível.

Considere o gráfico de Gantt da Figura 5, no qual é apresentado o plano de produção da solução ótima para uma instância com 2 máquinas de papel, 8 gramaturas e 3 períodos com 4 micro-períodos, cada um. Neste caso, podemos verificar que existe uma separação das gramaturas pelas duas máquinas de papel, na qual a solução do problema com separação é também ótima para o problema original. Isto nem sempre é possível e pode inclusive gerar problemas de infactibilidade se a separação não for realizada com cuidado. Em alguns casos, os conjuntos não precisam ser disjuntos, tendo intersecção entre as gramaturas atendidas por cada máquina.

Para gerar a separação prévia dos tipos de papel que serão produzidos em cada máquina de papel, foi definido o conjunto $A_{m}$, que indica todas as gramaturas que podem ser produzidas em cada máquina de papel $m$. A partir destes conjuntos, podemos definir que não pode haver troca de produção a partir de uma gramatura $k \notin K$, ou para uma gramatura $j \notin K$. Para tal, foram adicionadas as restrições (3.75) no modelo, que fixam em zero as variáveis de troca de produção para os casos acima mencionados.

$$
Z_{k j s m}=0, k, j \in K, s \in S, m \in M \mid k \notin A_{m} \vee j \notin A_{m}
$$

Vale salientar aqui que a divisão dos conjuntos de itens que podem ser produzidos por cada máquina de papel deve ser feita pelo tomador de decisões, que possui experiência e detém conhecimento prévio do problema. Possíveis critérios de divisão podem ser as quantidades demandadas no horizonte de planejamento, custos de troca na preparação de máquina, famílias distintas de produtos finais, limites de capacidade da produção de celulose virgem com relação a taxa de consumo dos itens, entre outros. Se consideramos 
Sequência de produção da máquina de papel 1

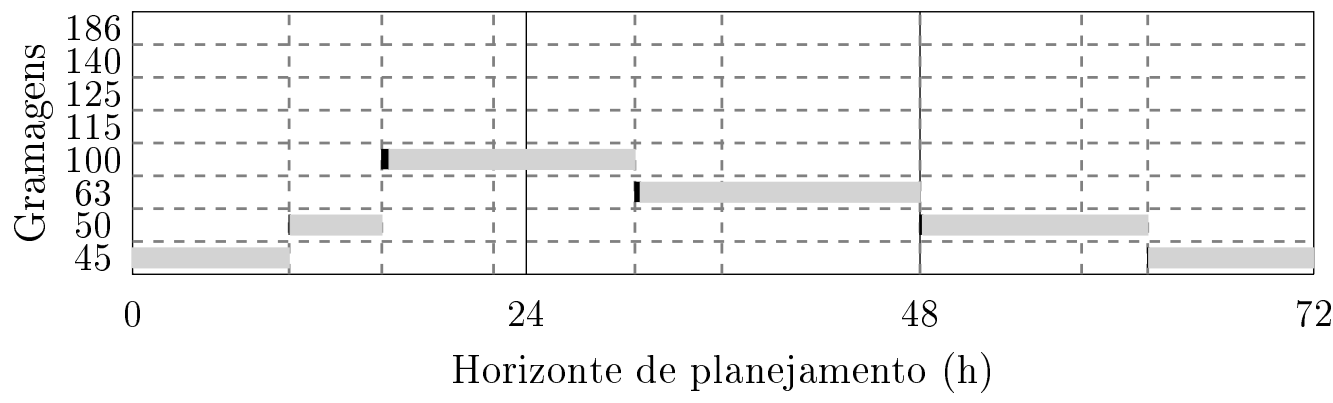

Sequência de produção da máquina de papel 2

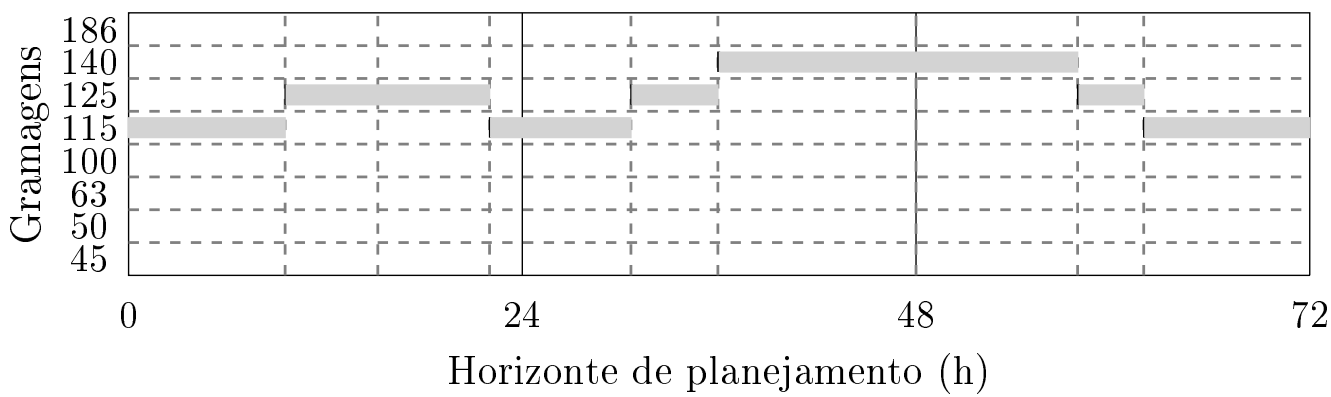

Setup

Produção

Figura 5: Planos de produção do modelo matemático original com divisão das gramaturas produzidas.

$A_{m}=K, \forall m \in M$, voltamos ao problema original, em que todas as máquinas estão livres para produzir todos os itens finais.

\subsubsection{Restrições de limitação na troca}

As restrições que limitam a troca de preparação proíbem trocas não desejadas pelo tomador de decisões. Segundo o que foi verificado durante as visitas, não são desejáveis trocas muito bruscas entre gramaturas produzidas consecutivamente. Além de aumentar as perdas durante o processo de troca, este tipo de mudança pode gerar instabilidade no equipamento, quebra da folha de papel ou quebra da própria máquina. Estas trocas são penalizadas pelo alto custo de troca na função objetivo, mas em alguns casos podem ser utilizadas pelo modelo matemático como artifício para reduzir ou aumentar a taxa de consumo e garantir a factibilidade das restrições de capacidade do estoque de celulose virgem. Desta forma, optamos por verificar a influência gerada pela proibição, a priori, destas trocas sobre os planos de produção gerados.

Considere $\Omega_{k j}$ um parâmetro definido pelo tomador de decisão, que indica o quanto a troca direta da gramatura $k$ para a gramatura $j$ é indesejável, e $\theta_{m}$ o limite aceito 
para esta "desejabilidade" de troca permitido para a máquina $m$. Com $\theta_{m}$ distintos por máquina $m$, podemos garantir que máquinas de papel com tecnologias distintas possam também aceitar trocas mais longas ou curtas do que as demais.

$$
Z_{k j s m} \leq\left\lfloor\frac{\theta_{m}}{\Omega_{k j}}\right\rfloor, j, k \in K, s \in S, m \in M
$$

As restrições (3.76) indicam que a variável de troca da gramatura $k$ para a gramatura $j$ no micro-período $s$ e máquina de papel $m$ será sempre limitada superiormente pelo piso da divisão do nível de aceitação da máquina $m$ pela desejabilidade desta troca. Neste caso, teremos os seguintes possíveis resultados:

$$
\begin{aligned}
& \Omega_{k j}>\theta_{m} \Rightarrow Z_{k j s m}=0, \\
& \Omega_{k j} \leq \theta_{m} \Rightarrow 0 \leq Z_{k j s m} \leq 1,
\end{aligned}
$$

ou seja, trocas mais indesejáveis do que o limite estipulado para a máquina $m$ são proibidas (3.77). As demais trocas são permitidas, pois seguem as regras das restrições (3.78) A Figura 6 apresenta um plano de produção, em que foram proibidas trocas entre gramaturas com diferença maior do que uma gramatura acima ou abaixo. Esta solução foi gerada com o mesmo exemplar de teste da solução da Figura 5. Ambas soluções são ótimas, variando apenas as restrições (3.76), que são respeitadas pela segunda solução.

\subsubsection{Restrições de geração de ciclos}

Como ciclo produtivo, consideramos um período de tempo variável no qual existe apenas um processo contínuo de subida e um processo contínuo de descida de gramaturas, não necessariamente nesta ordem. Em um gráfico de Gantt com papéis ordenados pela gramaturas de forma crescente, um ciclo produtivo poderia ser visto como um plano de produção em forma de seno ou cosseno, ou seja, uma subida contínua seguida de uma descida, ou uma descida seguida de uma subida. A Figura 7 mostra um gráfico de Gantt com este padrão produtivo. Isto pode ser desejável pela indústria por apresentar um plano mais estável de produção, que tende a reduzir perdas com preparação de máquina e garante a estabilidade dos equipamentos sem que haja mudanças bruscas nas taxas de produção e consumo. Da mesma forma que ocorrido nas Figuras 5 e 6, o exemplar de 
Sequência de produção da máquina de papel 1

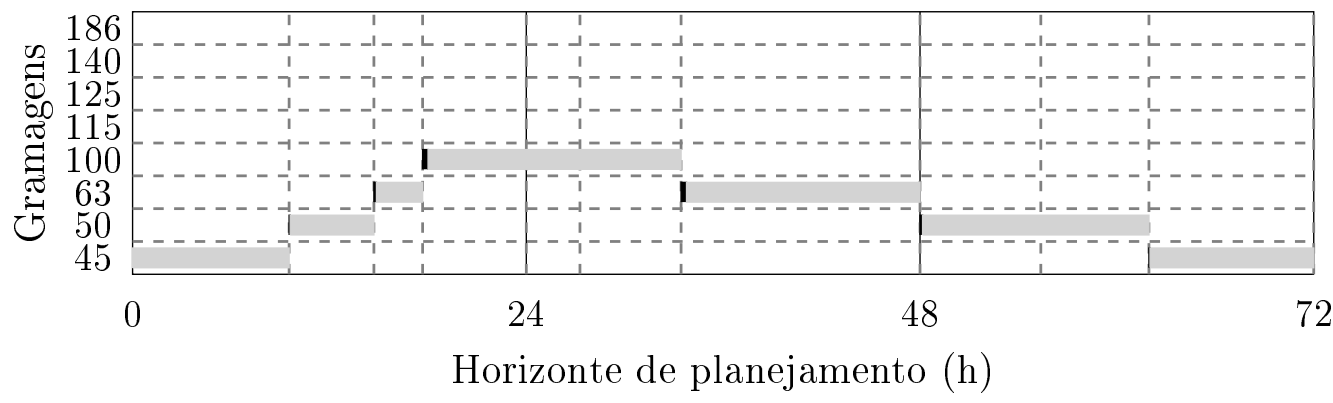

Sequência de produção da máquina de papel 2

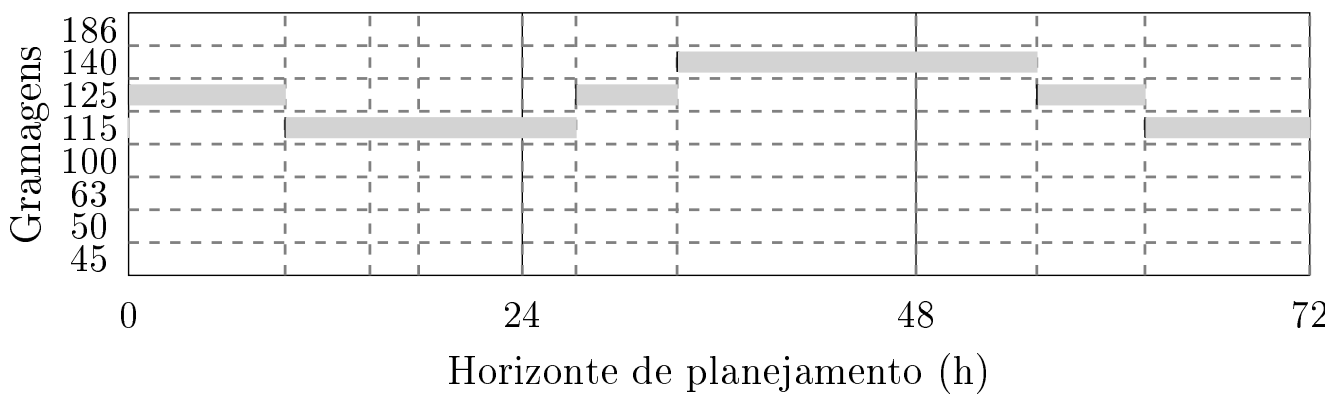

- Setup

Produção

Figura 6: Planos de produção do modelo matemático com limitação na troca de produtos.

teste utilizado para gerar a solução da Figura 7 foi a mesma. Nesta caso, a variação da solução ótima foi gerada pela consideração dos ciclos de produção.

Para representar tais restrições, considere a adição de uma matriz auxiliar $\phi_{k j}$, que indica se a troca está inserida em uma subida de gramatura $\left(\phi_{k j}=1\right)$, em uma descida de gramatura $\left(\phi_{k j}=-1\right)$, ou em um ponto estável $\left(\phi_{k j}=0\right)$. Os dados $W_{m}^{i n i}$ indicam se a máquina $m$ inicia o horizonte de planejamento em subida 1 ou descida 0. Além disso, considere também os conjuntos $K_{m}^{\text {Base }}$ e $K_{m}^{\text {Topo }}$ que indicam, para a máquina de papel $m$, os itens que estão na base e no topo dos ciclos de produção, respectivamente. Somente nestes conjuntos de itens será permitido fazer a inflexão entre subida e descida. Estes conjuntos foram criados para permitir que gramaturas diferentes possam servir de limites de ciclo nos casos onde $K \backslash A_{m} \neq \emptyset$. Na Figura 7 , o plano de produção têm ciclos, onde os itens que permitem inflexão do ciclo de produção são distintos. No caso do plano da máquina de papel 1 , temos como base a gramatura $45 \mathrm{~g} / \mathrm{m}^{2}$ e como topo a gramatura 100 $\mathrm{g} / \mathrm{m}^{2}$, enquanto o da máquina de papel 2 tem como gramatura mínima $115 \mathrm{~g} / \mathrm{m}^{2}$ (base) e máxima $186 \mathrm{~g} / \mathrm{m}^{2}$ (topo).

Além dos dados adicionais, foi criado um conjunto de variáveis auxiliares $W_{s m}$, que controlam e carregam a informação sobre o processo de subida e descida do ciclo de 
Sequência de produção da máquina de papel 1

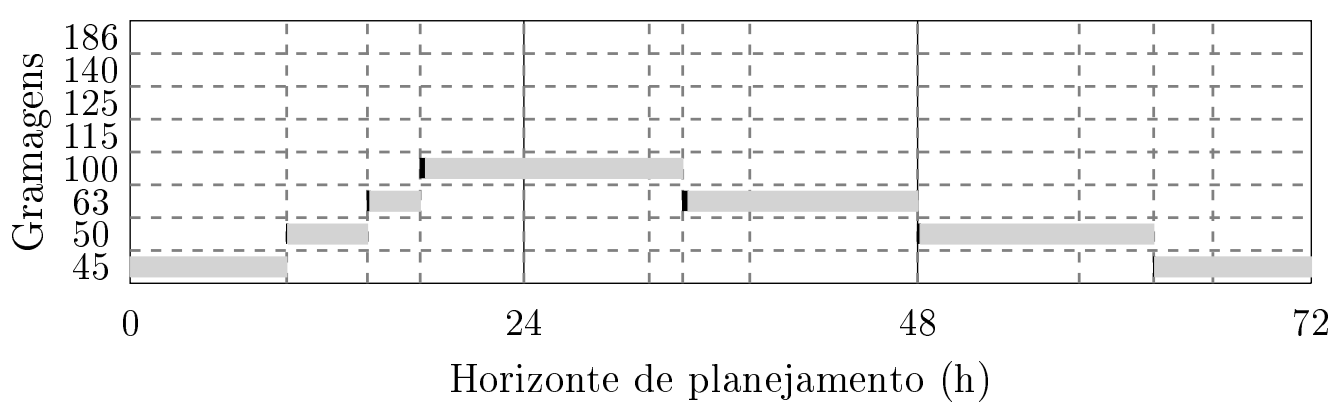

Setup

Produção

Sequência de produção da máquina de papel 2

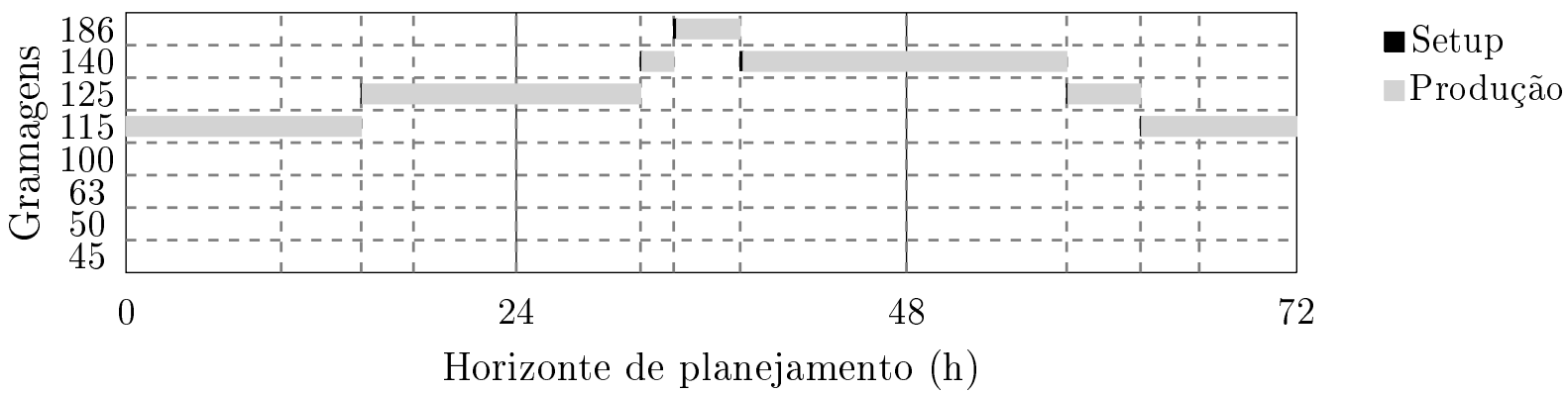

Figura 7: Planos de produção do modelo matemático com ciclos de produção.

produção. Note que $W_{s m}=1$ indica que o ciclo está no período de subida, enquanto $W_{s m}=0$ indica uma descida. O estado inicial do ciclo de produção de cada máquina de papel $\left(W_{0 m}\right)$ é definido pelo tomador de decisão, de acordo com o plano de produção executado anteriormente. A seguir são apresentadas as restrições adicionais de controle de ciclo.

$$
\begin{aligned}
Z_{k j s m} & \leq W_{s m}, j, k \in K, s \in S, m \in M \mid \phi_{k j}=1, \\
Z_{k j s m} & \leq\left(1-W_{s m}\right), j, k \in K, s \in S, m \in M \mid \phi_{k j}=-1, \\
W_{s m} & =W_{s-1, m}+\sum_{\substack{j \in K_{m}^{\text {Base }} \\
k \in K \backslash K_{m}^{\text {Base }}}} Z_{k j, s-1, m}-\sum_{\substack{j \in K_{m}^{T o p o} \\
k \in K \backslash K_{m}^{T o p o}}} Z_{k j, s-1, m}, s \in S, m \in M, \\
W_{1 m} & =W_{m}^{i n i}, m \in M .
\end{aligned}
$$

As restrições (3.79) e (3.80) fixam e liberam as variáveis de troca de produção, dependendo do estado da variável $W_{s m}$. Quando o ciclo está em processo de subida $\left(W_{s m}=1\right)$, todas as variáveis $Z_{k j s m}$ são liberadas se $\phi_{k j}=1$ e fixadas em zero se $\phi_{k j}=-1$, ou seja, todas as trocas que representam descida são proibidas. A situação se inverte quanto 
$W_{s m}=0$, ou seja, durante o processo de descida somente trocas de descida são aceitas. Vale a pena ressaltar que as trocas com $\phi_{k j}=0$ não são afetadas por nenhuma das restrições, pois não representam subida e nem descida, sendo permitidas durante todo o ciclo. As restrições (3.81) fazem o controle de mudanças do ciclo a partir do estado

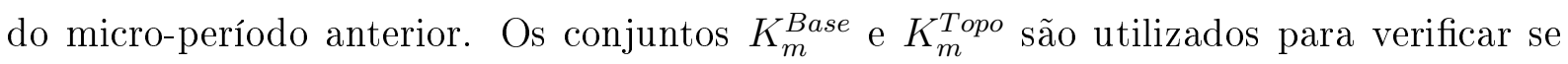
uma subida ou uma descida foram concluídas. Quando está ocorrendo um processo de subida $\left(W_{s-1, m}=1\right)$, todas as variáveis com $j \in K_{B}$ são nulas, pois são variáveis de descida. Sendo assim, o valor de $W_{s m}$ só poderá obter valor 1 , se existe $Z_{k j s m}=1$ tal que $j \in K \backslash K_{m}^{B}$, ou 0 , caso contrário. No caso de $W_{s-1, m}=0$, o oposto ocorre, possibilitando apenas que o valor de $W_{s m}$ seja igual ao do seu antecessor, ou aumente. Finalmente, as restrições (3.82) iniciam o processo a partir do estado inicial de ciclo das máquinas $\left(W_{m}^{i n i}\right)$.

\subsection{Testes computacionais preliminares}

Estes testes computacionais têm o objetivo de veirificar a corretude e consistência do modelos propostos, além de possibilitar análises quantitativas e qualitativas das soluções ótimas de quatro variações do modelo matemático proposto. As análises são embasadas em gráficos de fluxos de celulose e papel entre as unidades produtivas, níveis de estoque e velocidades de trabalho das unidades produtivas. O objetivo é apontar as vantagens e desvantagens de cada variação do modelo, levando em consideração as características exemplares de teste resolvidos.

Foram testadas quatro variações do modelo matemático, sendo elas: o modelo base (3.45)-(3.74), denominado de GLSP1; o modelo GLSP1 com adição de restrições de limitação de itens produzidos (3.45)-(3.75), denominado de GLSP2; o modelo GLSP2 com adição de restrições de limitação na troca (3.45)-(3.76), denominado GLSP3; e o modelo GLSP3 com adição de restrições de geração de ciclos (3.45)-(3.82), denominado GLSP4.

A Seção 3.5.1 apresenta as características dos exemplares gerados para estes testes preliminares, bem como a forma como os custos do sistema foram calculados. A definição dos limites de trocas na preparação das máquinas de papel é apresentada na Seção 3.5.2. A forma como as gramaturas foram divididas entre as máquinas de papel é apresentada na Seção 3.5.3 e, finalmente, a Seção 3.5.4 apresenta como foram definidas as gramaturas de base e topo dentro do conjunto de gramaturas passíveis de produção em cada máquina de papel. Os resultados preliminares são apresentados na Seção 3.5.5. 


\subsubsection{Exemplares de teste utilizados}

Foram gerados exemplares de pequeno porte com apenas 8 gramaturas distintas de papel e apenas 3 períodos de produção (dias). Cada período foi dividido em 4 microperíodos de tamanho variável. Foram ainda definidos exemplares com 1 e 2 máquinas de papel e variadas cargas de produção. As características das variadas cargas de produção são apresentadas na Tabela 13, situada na Seção 6.1. No total, foram gerados 30 exemplares, sendo 15 variações de carga de produção para 1 e 2 máquinas. Para calcular os custos da função objetivo, consideramos os seguintes fatos com relação a cada parcela:

- Custo de estoque $\left(h_{j t}^{+}\right)$: O custo de estoque representa a soma do custo de oportunidade de possíveis investimentos com o valor referente ao preço do produto estocado e o custo do espaço necessário para sua estocagem. Como não sabemos com precisão o custo do espaço, definimos uma adição pequena. O valor condensado utilizado para a estocagem de uma tonelada do produto final foi de $25 \%$ do valor do produto em um ano, ou seja, $h_{j t}^{+}=\frac{25 \% \cdot \text { price }_{j}}{365}$, no qual price $_{j}$ representa o preço de uma tonelada da gramatura $j$.

- Custo de atraso $\left(h_{j t}^{-}\right)$: O custo de atraso na entrega representa uma combinação entre custos associados a pagamentos de multas por não entrega de produto dentro do prazo e possíveis perdas de clientes. Como este tipo de prática é pouco desejável e dada a dificuldade em obter médias para tais dados, optamos por considerar um custo elevado para o atraso. Foi considerado que o custo de atraso $h_{j t}^{-}=10 \cdot h_{j t}^{+}$ (dez vezes o custo de estoque).

- Custo de preparação de máquina $\left(s c_{k j m}\right)$ : Como custo de preparação de máquina consideramos uma perda proporcional a matéria-prima utilizada. Dado que esta matéria-prima pode ser reutilizada após um reprocessamento, apenas a quinta parte da quantidade de matéria-prima foi considerada no cálculo do custo de preparação de máquina. Desta forma, o custo de preparação de máquina é o seguinte: $s c_{k j m}=$ price $_{j} \cdot \frac{s l_{k j m}}{5}$.

Nos cálculos dos custos apresentados acima price $_{j}$ indica o preço médio de uma tonelada da gramatura $j$ e os percentuais utilizados destes valores na composição dos custos foram definidos a partir do conhecimento de um especialista da área. Os valores de price $_{j}$ foram obtidos a partir de um custo médio dos itens de cada gramatura contidos na carteira de pedidos, resultando em termos de $U S \$ /$ ton. Por exemplo, para obter o price $_{j}$ da 
gramatura $135 \mathrm{~g} / \mathrm{m}^{2}$, foi feita a soma dos preços de todos os itens deste tipo de papel, dividida pela quantidade de toneladas necessárias para produzir estes itens. O incentivo a produção $\gamma$ considerado é da ordem de 0,1 , pois representa apenas um incentivo à produção de energia dado que não foi possível definir esta parcela da função objetivo de forma monetária. O valor de $\varepsilon$ tem valor de 0,01 , pois tem o objetivo de diferenciar soluções, com relação a quantidade de trocas de velocidade do digestor, que tenham planos de produção iguais nas máquinas de papel.

\subsubsection{Definição dos limites de trocas em cada máquina de papel}

Foi definido para os modelos GLSP3 e GLSP4, que as trocas de gramatura não poderiam ultrapassar mais de duas gramaturas de distância, ou seja, se considerarmos as gramaturas de forma ordenada, não poderá haver saltos maiores do que de duas gramaturas na produção. Por exemplo, se a gramatura $i$ é produzida no micro-período $s$, somente poderemos produzir uma das gramaturas do grupo $\{i-2, i-1, i, i+1, i+2\}$ no micro-período $s+1$.

Para tal, definimos $\theta_{m}=2$ e $\Omega_{k j}=|k-j|$. Desta forma, temos que sempre que a diferença nos índices for maior do que $2\left(\Omega_{k j}>2\right)$, as variáveis $Z_{k j s}$ são limitadas superiormente a zero pelas restrições $(3.76)$, pois $\left\lceil\frac{\theta_{m}}{\Omega k j}\right\rceil=0$. Na prática, estes valores podem ser estimados pela diferença entre a gramatura dos papéis produzidos, pela mudança de famílias de papéis e também pelo conhecimento específico do tomador de decisões da linha produtiva. O tomador de decisões pode variar o valor de $\Omega$ de acordo com as condições da fábrica, carteira de pedidos e até mesmo variar estes valores durante o dia, caso ocorra algum imprevisto na produção.

\subsubsection{Divisão dos itens produzidos em cada máquina de papel}

A divisão de itens por máquina de papel foi feita de modo a dividir a carga de produção de acordo com a demanda, atrasos e tempo de processamento de cada item. A partir do item de menor gramatura para o item de maior gramatura, alocamos os itens para serem produzidos em cada máquina a partir da primeira. A alocação é feita para uma máquina até que ela ultrapasse a carga média (carga total necessária para atender a demanda do horizonte de planejamento e atrasos divididos pelo número de máquinas). Como a divisão não se tornaria totalmente equitativa, alocamos sempre a última gramatura da máquina anterior para também ser produzida na máquina seguinte. Ou seja, a última gramatura 
produzida em uma máquina $m$ será a primeira gramatura produzida na máquina $m+1$. Este tipo de sobreposição permite que a demanda desta gramatura seja dividida entre as máquinas que a produzem.

O procedimento utilizado leva em consideração apenas a carga de trabalho a fim de dividir o trabalho entre as máquinas de papel, pois consideramos máquinas homogêneas na geração dos exemplares de teste. Dificuldades operacionais podem ser mais relevantes nesta divisão em casos onde as máquinas tenham características distintas. Neste caso, o conhecimento do tomador de decisões da empresa têm papel fundamental para definir estes grupos de forma mais precisa.

\subsubsection{Limites de topo e base de ciclos}

Foram considerados como limites dos ciclos de produção as maiores e menores gramaturas passíveis de produção em cada máquina de papel. Por exemplo, uma máquina de papel que pode produzir as gramaturas 115, 120, 130 e $145 \mathrm{~g} / \mathrm{m}^{2}$, terá como base do ciclo a gramatura $115 \mathrm{~g} / \mathrm{m}^{2}$ e como topo a gramatura $145 \mathrm{~g} / \mathrm{m}^{2}$. Mais de uma gramatura poderia ser definida como topo e/ou como base, caso não seja necessário a subida/descida até a última/primeira gramatura. O tomador de decisão pode definir estes conjuntos de acordo com seu conhecimento do problema e os tipos de ciclo de produção que deseja obter nas soluções.

\subsubsection{Resultados preliminares}

As análises dos testes preliminares são feitas em duas partes. Na primeira parte, é analisado a influência gerada por cada variante do modelo matemático em cada parcela de custo da função objetivo. Na segunda parte, são analisados os gráficos das soluções de dois exemplares para apresentar as influências das restrições adicionais nas unidades produtivas do processo.

A Figura 8 apresenta os resultados médios de cada parcela da função objetivo para exemplares com uma máquina de papel. Neste gráfico, podemos verificar que não existe diferença entre os modelos GLSP1 e GLSP2, pois não existe divisão na produção, visto que apenas uma máquina de papel é responsável por toda a produção. A adição de redução nos saltos de produção (GLSP3), gerou uma pequena redução nos custos de estoque e aumento nos custos de preparação de máquina e atraso. Este aumento foi gerado pela necessidade de mais trocas para atingir uma gramatura fora da faixa limite estabelecida. 
Com a adição de ciclos de produção (GLSP4), houve um aumento nos custos de estoque e atraso e diminuição nos custos de preparação de máquina. Este padrão é esperado, pois estas restrições diminuem a flexibilidade do plano de produção, ao restringir o grupo de itens que podem ser produzidos em sequência curta de tempo. Ao mesmo tempo, evitam trocas entre produtos muito distantes, reduzindo os custos de preparação de máquina. Pode-se verificar que não houve variação significativa nos custos totais (acréscimo de 4,43\% nos custos totais), dado que o custo de preparação de máquina compensa parte dos demais custos e gera um plano de produção mais suave do ponto de vista prático.

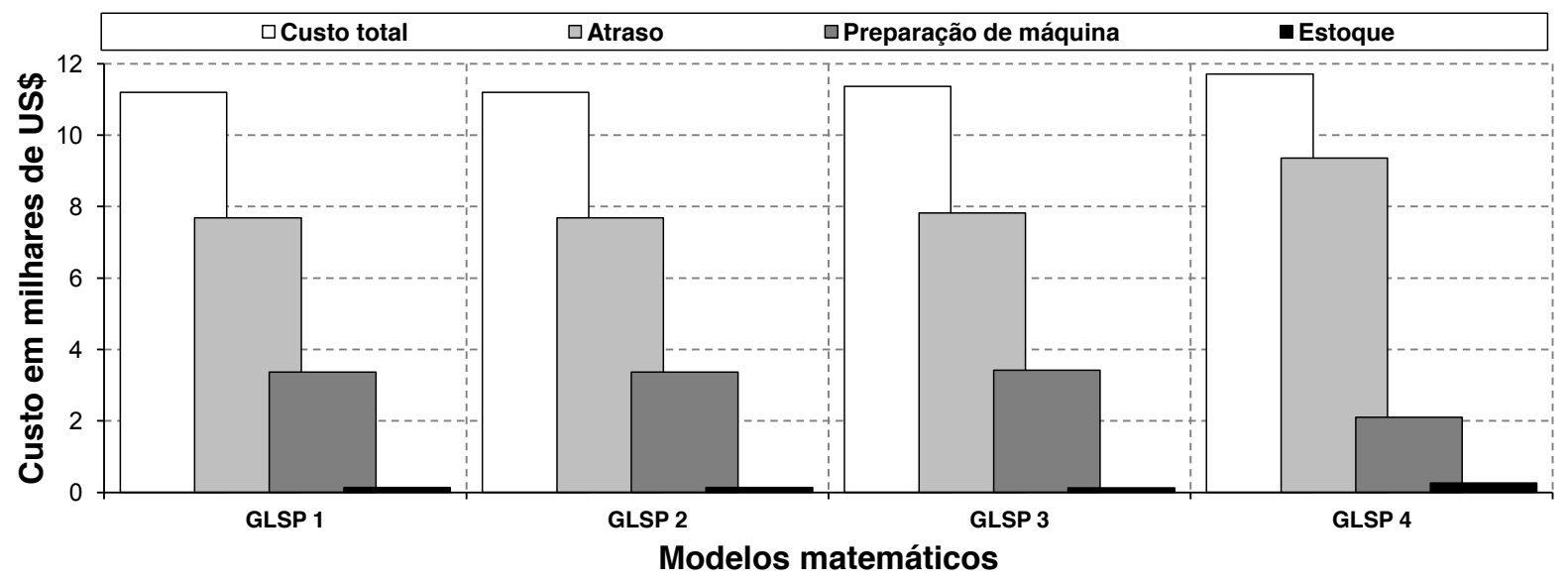

Figura 8: Gráfico de médias das parcelas de custo da função objetivo para exemplares com uma máquina de papel.

A Figura 9 apresenta os resultados, separadamente, por padrão de carga de trabalho para exemplares com uma máquina de papel. Para cada padrão de trabalho são apresentados os resultados de cada variante do modelo e estes são separados pelas linhas de grade do gráfico. Analisando a Figura 9, fica visível que as mudanças dos custos ocorrem na maioria dos padrões de carga de trabalho. A exceção ocorre com o padrão 2, onde a carga de trabalho da máquina de papel é pequena com relação a capacidade produtiva da mesma. No padrão 2, existe apenas uma variação mínima dos custos no modelo GLSP4, onde existe uma redução ínfima nos custos de atraso e aumento nos de estoque e preparação de máquina. O acréscimo gerado no custo total foi de $0,17 \%$.

Os custos médios dos exemplares com duas máquinas de papel são apresentados na Figura 10. Neste gráfico, ficam aparentes as diferenças entre os modelos GLSP1 e GLSP2, dado que as gramaturas são designadas para serem produzidas em máquinas distintas com apenas uma pequena sobreposição (Seção 3.5.3). Não houve mudanças aparentes nas soluções geradas pelos modelos GLSP2 e GLSP3. Isto tem relação com a redução na quantidade de gramaturas que podem ser produzidas em cada máquina de papel. 


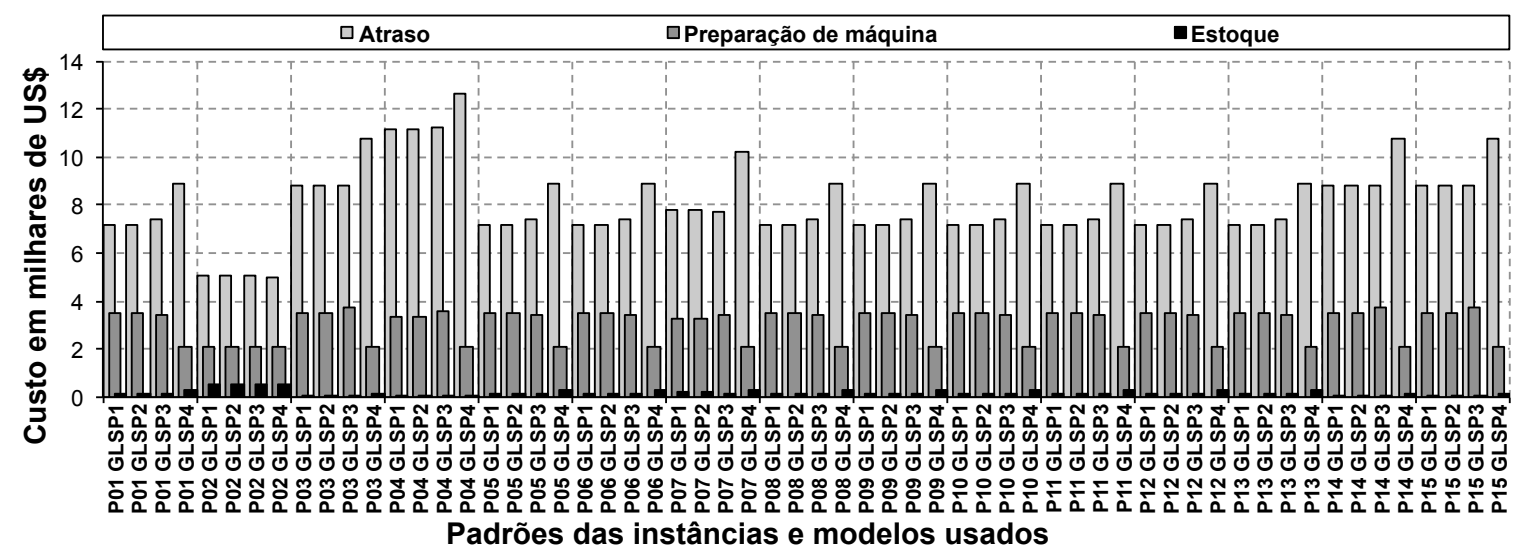

Figura 9: Gráfico de parcela de custos da função objetivo por instância com uma máquina de papel.

Como as gramaturas são divididas quase que ao meio de acordo com a demanda (para dividir a carga de trabalho), não existe a possibilidade de trocas muito longas, o que reduz a eficiência das restrições adicionais do modelo GLSP3. De modo geral, os custos de atraso tiverem um aumento significativo e os custos de estocagem uma leve variação. Esta variação foi parcialmente compensada pela redução nos custos de preparação de máquina e os custos totais tiveram um acréscimo médio de 15,01\%, quando comparados os resultados dos modelos GLSP1 e GLSP4.

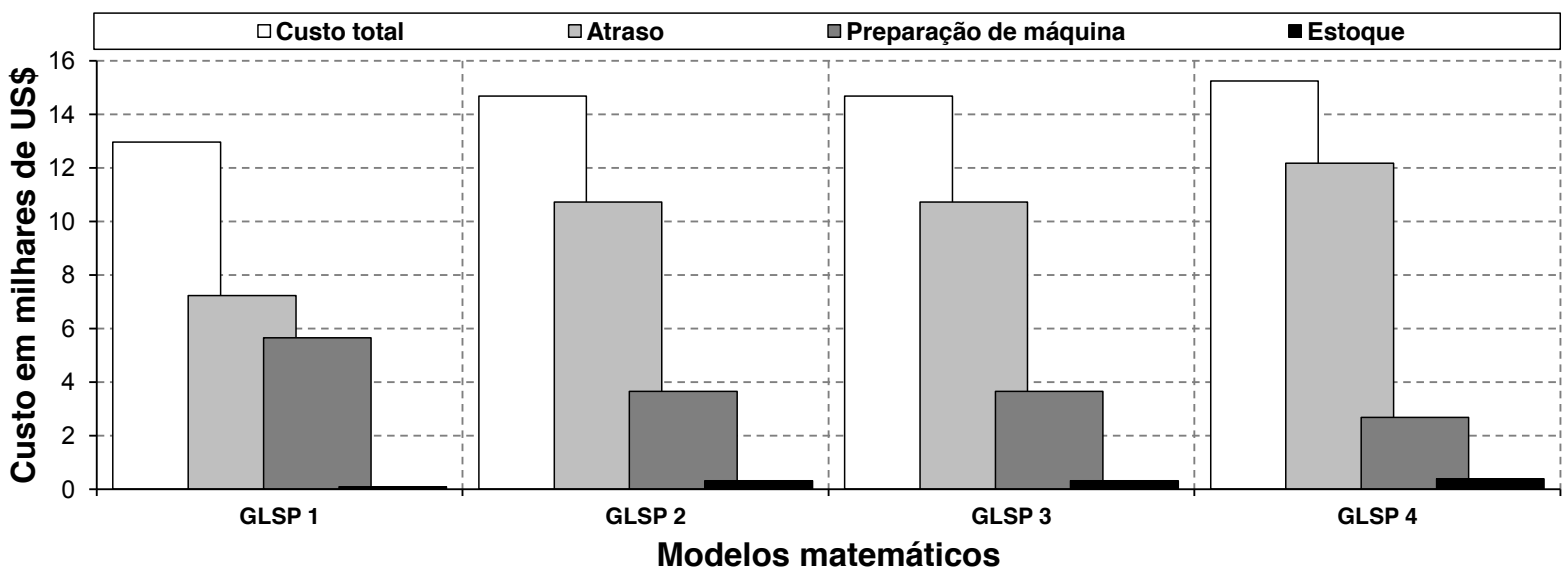

Figura 10: Gráfico de médias das parcelas de custo da função objetivo para exemplares com duas máquinas de papel.

A Figura 11 mostra que houve mudanças nos custos de produção de todos os padrões de carga verificados. A exceção ocorre quando comparamos os modelos GLSP2 e GLSP3, como mencionado na análise das médias e representado na Figura 10. A maior parte dos custos se deve ao atraso nas entregas das demanda, pois os custos de atraso são altamente penalizados. Devido ao fato deste setor industrial ter cargas elevadas de trabalho, é comum que as demandas ultrapassem as capacidades produtivas. 


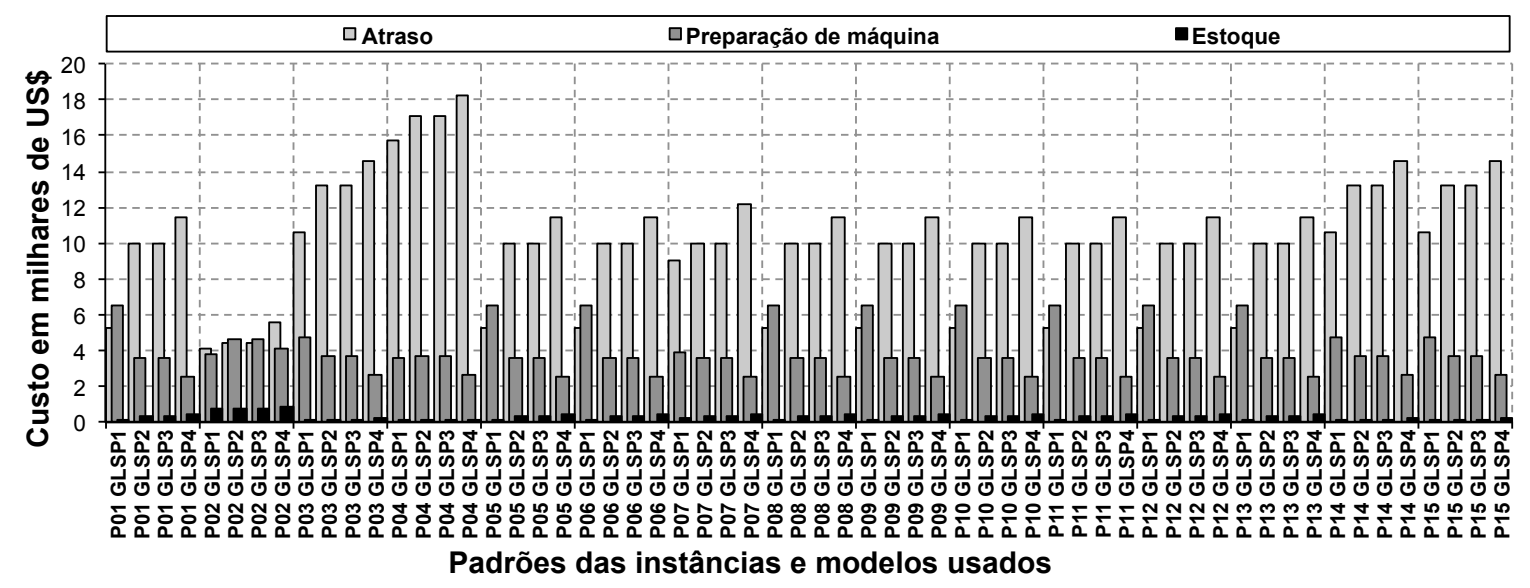

Figura 11: Gráfico de parcela de custos da função objetivo por instância com duas máquinas de papel.

Analisamos a seguir as soluções geradas pelos quatro modelos, do ponto de vista de cada unidade crítica do processo produtivo, sendo elas: a velocidade de trabalho do digestor, o nível de estoque de celulose virgem, o sequenciamento da(s) máquina(s) de papel, os níveis de estoque de licor negro fraco e concentrado e a quantidade de vapor produzido por dia. As duas soluções utilizadas são de exemplares do padrão 1 (P01), nas quais não existem gargalos produtivos aparentes. Estes exemplares foram escolhidas por terem resultados com características similares aos valores médios obtidos. A diferença entre os dois exemplares usados para esta análise se dá na quantidade de máquinas de papel, sendo que a primeira conta com uma máquina de papel e a segunda conta com duas máquinas de papel. Estes exemplares são denominadas M1 e M2 nos gráficos, respectivamente.

A Figura 12 apresenta as velocidades para trabalho do digestor definidas nos planos de produção gerados em cada modelo. O uso do digestor aparenta ser mais intenso nos casos dos modelos GLSP3 e GLSP4. As limitações nas trocas de produção e a adição de ciclos de produção tornam mais difícil a mudança para gramaturas que consomem menos celulose virgem (menor gramatura) e por consequência, o digestor é obrigado a aumentar a velocidade de trabalho a fim de atender as demandas de celulose pela máquina de papel.

Os níveis de estoque de celulose virgem (Figura 13) não apresentam mudanças significativa, pois o aumento/diminuição no nível do tanque de celulose virgem não influenciam diretamente a função objetivo. Como o digestor está trabalhando dentro do intervalo de produção normal, ou seja, não existe sobrecarga na demanda de celulose virgem, não se torna necessário gerar grandes estoques de celulose virgem. Neste caso, a velocidade de trabalho do digestor acompanha as mudanças na demanda por celulose da máquina de papel, que é maior no caso dos modelos GLSP3 e GLSP4. Níveis de celulose virgem 


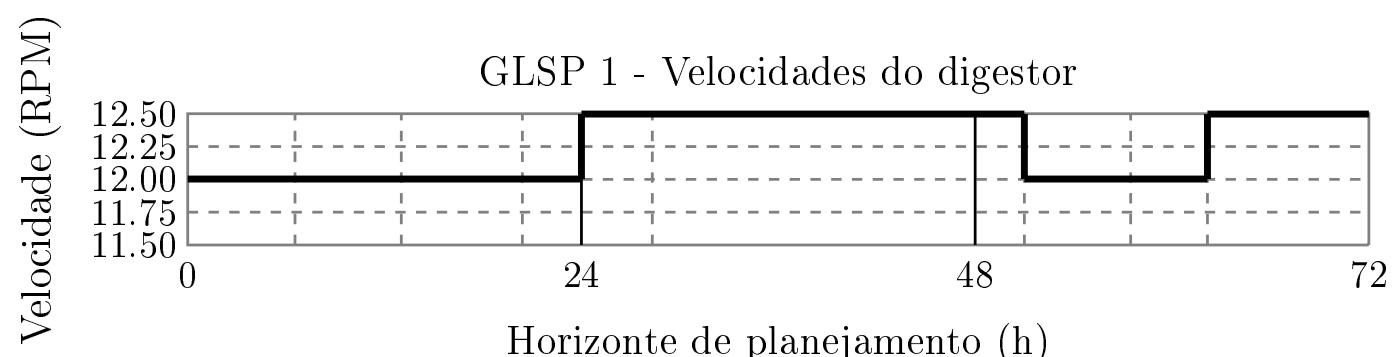

Horizonte de planejamento $(\mathrm{h})$

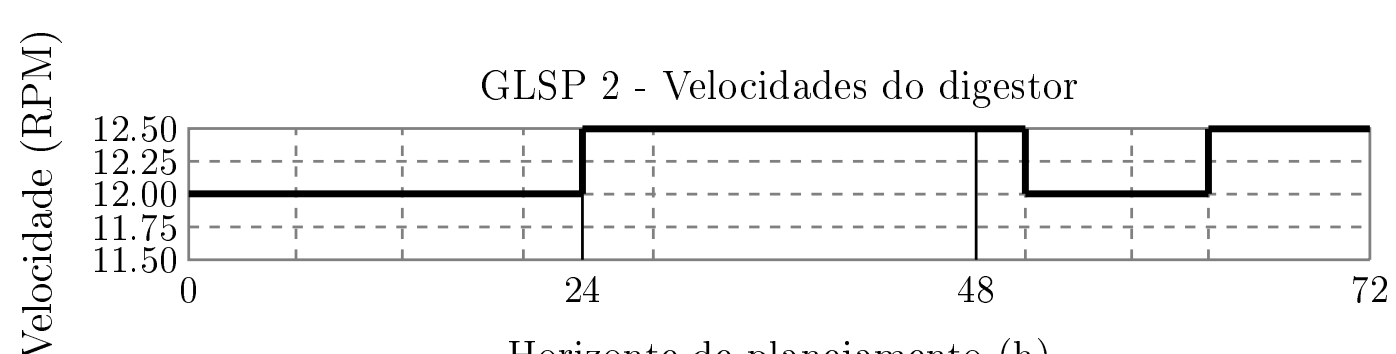

Horizonte de planejamento $(\mathrm{h})$

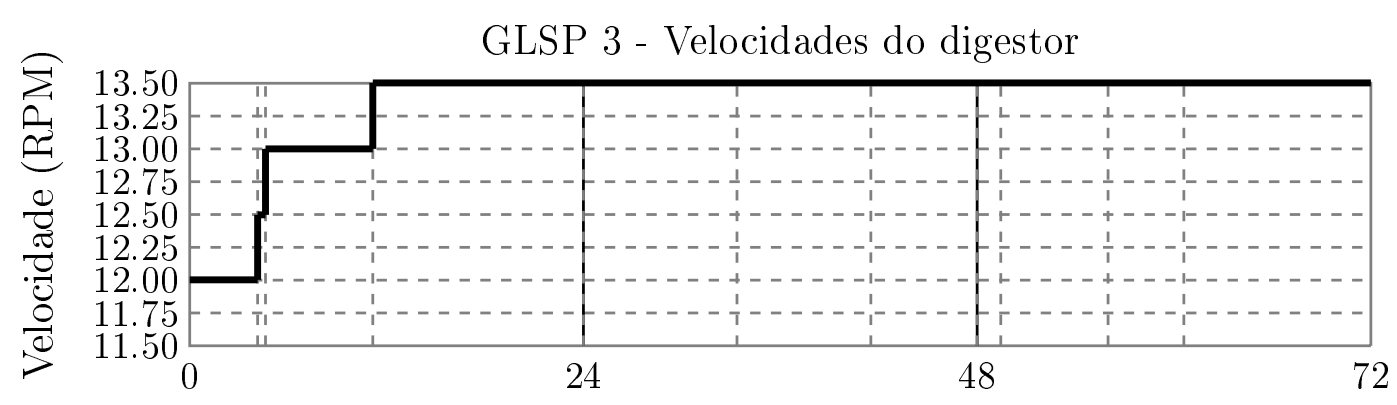

Horizonte de planejamento (h)

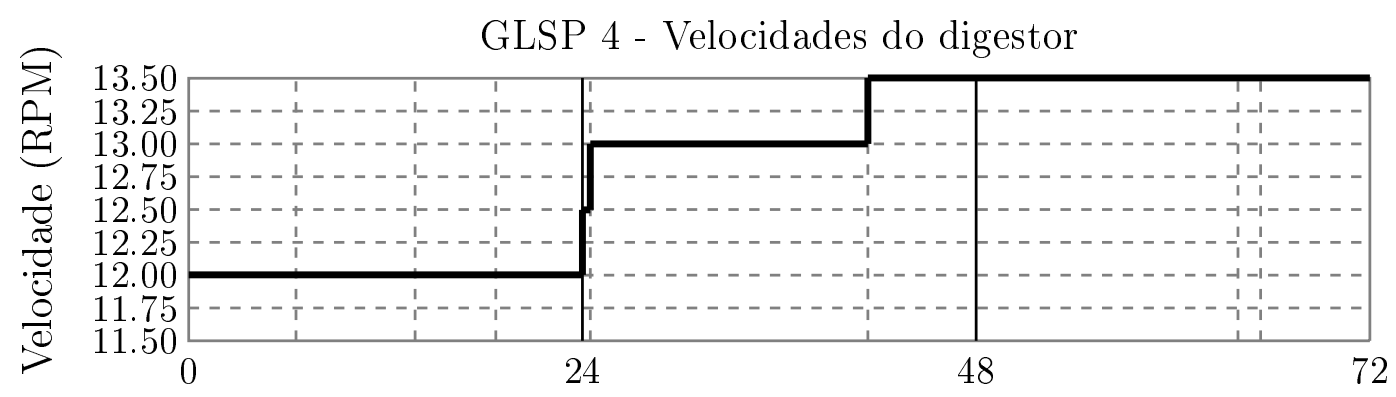

Horizonte de planejamento $(\mathrm{h})$

Figura 12: Sequência de velocidades de trabalho do digestor - instância M1.

maiores podem ser desejados em casos práticos. Para adicionar tal prática ao modelo, incentivos podem ser adicionados a função objetivo com metas com os níveis desejados de estoque ao final do horizonte de planejamento.

As sequências de produção e os tamanhos dos lotes de produção da máquina de papel são apresentados na Figura 14. O modelo GLSP1 gerou um resultado próximo a um ciclo produtivo conforme definido, no entanto, a maior gramatura (topo) não chegou a ser produzida e existem saltos na produção, como no micro-período 3, onde ocorre um salto ao preparar a máquina de papel para produzir a gramatura $104 \mathrm{~g} / \mathrm{m}^{2}$ após a 

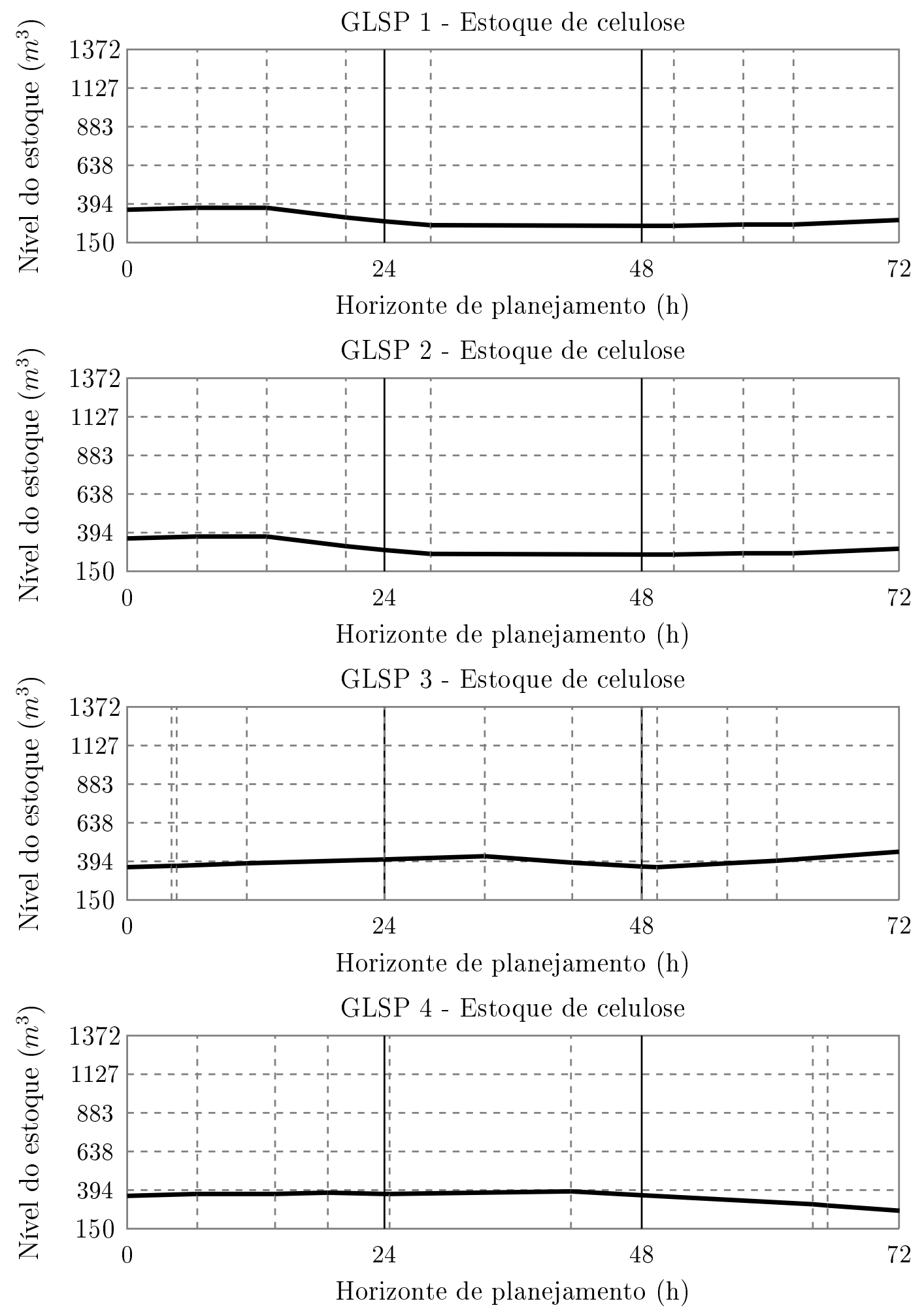

Figura 13: Nível de estoque de celulose virgem - instância M1.

produção da gramatura $63 \mathrm{~g} / \mathrm{m}^{2}$. No caso do modelo GLSP3, este salto não é possível e ocorre uma inversão nas produções das gramaturas 104 e $100 \mathrm{~g} / \mathrm{m}^{2}$ com a gramatura 75 $\mathrm{g} / \mathrm{m}^{2}$, eliminando assim a mudança em questão. O modelo GLSP4, gerou um resultado inesperado, pois o ciclo produtivo não chegou a metade (não atingiu a gramatura mais 
pesada). Isto pode ter ococrrido devido ao valor dos custos de preparação de máquina em conjunto com a baixa demanda das gramaturas mais pesadas $\left(170 \mathrm{~g} / \mathrm{m}^{2}\right.$ e $\left.240 \mathrm{~g} / \mathrm{m}^{2}\right)$, pois em nenhum dos resultados dos modelos matemáticos foram produzidas estas gramaturas. Como o ciclo de produção utilizado nos testes do modelo GLSP4 obriga que o processo de subida termine na gramatura $240 \mathrm{~g} / \mathrm{m}^{2}$.

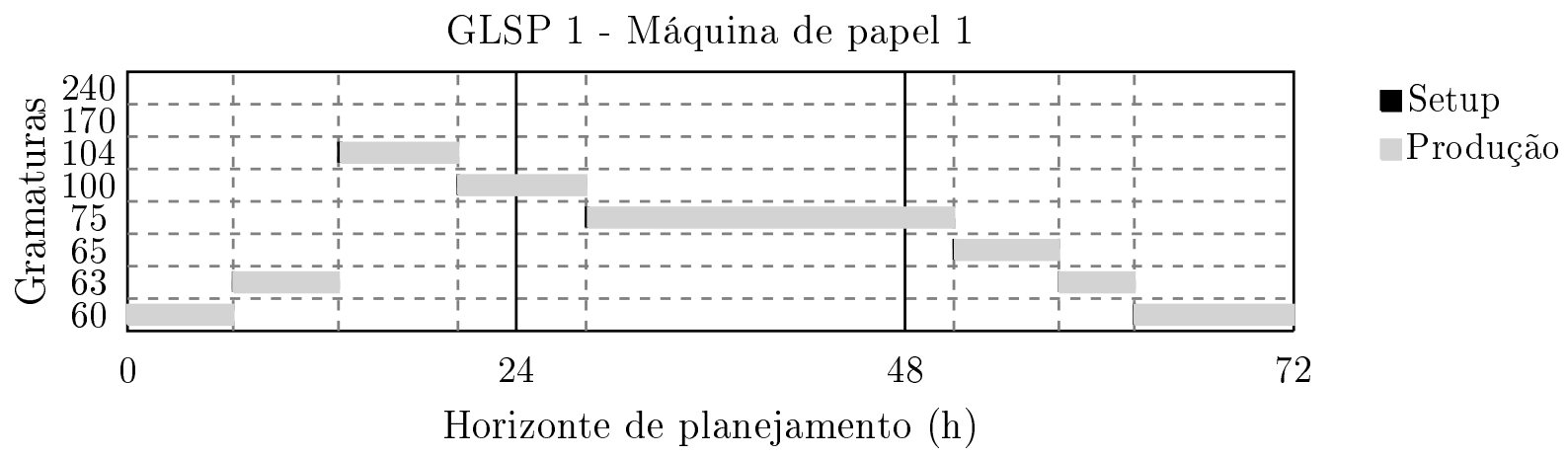

GLSP 2 - Máquina de papel 1

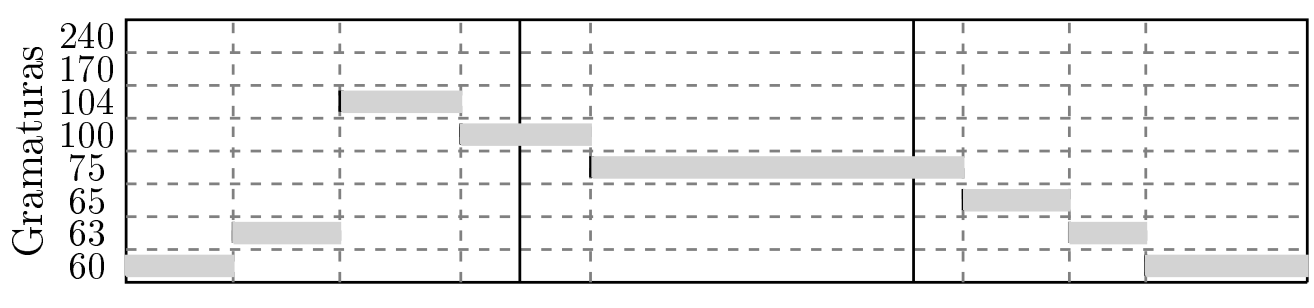

- Setup

Produção

0

24

48

72

Horizonte de planejamento (h)

GLSP 3 - Máquina de papel 1

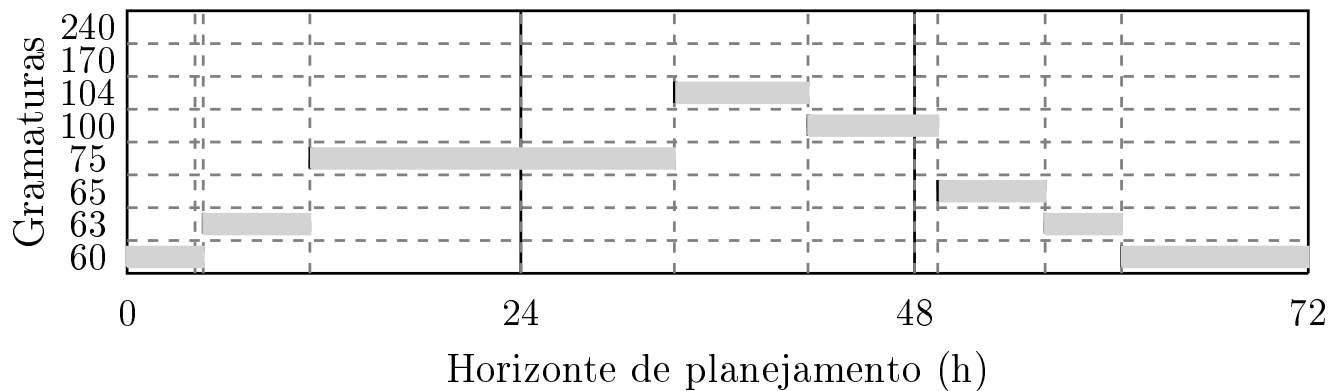

Setup

Produção

GLSP 4 - Máquina de papel 1

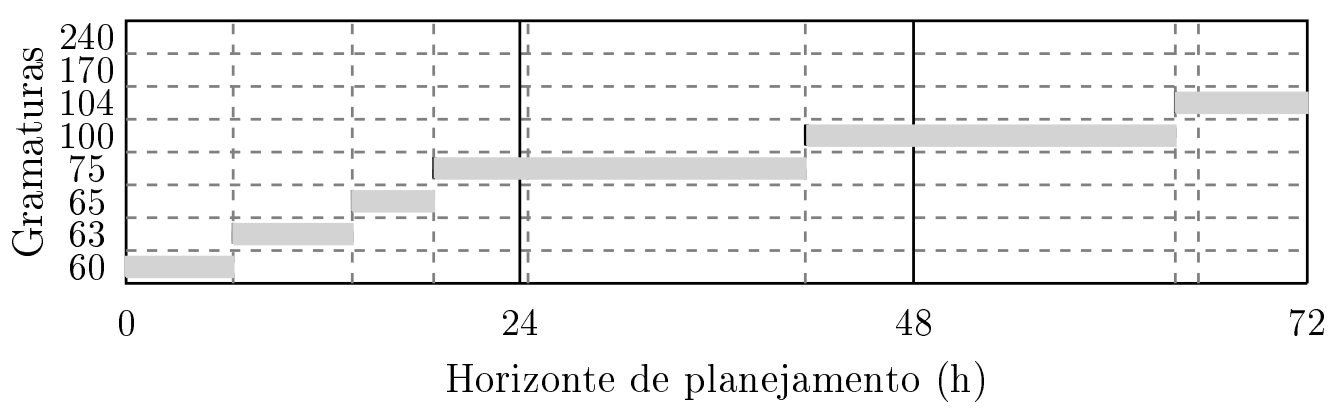

Setup

Produção

Figura 14: Sequência de produção ótima para a máquina de papel - instância M1.

A Figura 15 demonstra que o nível de estoque de licor negro fraco não é um gargalo de 
produção para a instância considerada, pois seu limite máximo não é atingido no horizonte de planejamento, e apresenta uma queda acentuada para três dos quatro modelos. Os resultados dos modelos GLSP3 e GLSP4 apresentam menor variação no nível de licor negro fraco, causada pela maior taxa de produção deste licor no digestor (velocidades maiores).

A Figura 16 apresenta o nível de estoque de licor negro concentrado. Podemos verificar que este nível se encontra baixo na maior parte do horizonte de planejamento. Isto indica que o evaporador é o gargalo da linha de recuperação química, pois a caldeira de recuperação é capaz de consumir todo o licor negro concentrado produzido e manter o nível de estoque no valor mínimo. O padrão de produção e consumo de licor negro concentrado varia ligeiramente no início do horizonte de planejamento. No entanto, esta variação se deu devido a alternativas de solução que são indiferenciáveis do ponto de vista da função objetivo. Apesar da forma aparentemente distinta, a equivalência entre as soluções podem ser verificadas pela soma das quantidade produzidas de vapor durante todo o horizonte de planejamento. Como os níveis iniciais e finais do estoque de licor negro concentrado também são identicos, o consumo acumulado deste licor também foi o mesmo e também indica a equivalência das soluções.

A Figura 17 apresenta as quantidades de vapor produzidas durante o horizonte de planejamento, agregadas por período. Apesar da variação aparente nos resultados dos modelos, a quantidade de vapor produzido no horizonte de planejamento é a mesma nas quatro soluções. Como não existe variação no incentivo a produção de vapor (este incentivo não varia entre períodos ou horário do dia) e a caldeira de recuperação química trabalha com folga, múltiplas soluções ótimas são possíveis para esta parcela da função objetivo. A diferenciação nos ganhos com a produção entre dias, ou mesmo horas do dia, poderia modificar este fato. Como o excedente do vapor é transformado em energia elétrica, esta variação tem embasamento, visto que a energia elétrica vendida para grandes consumidores têm maior valor em horários de pico. A caldeira poderia reduzir a produção de vapor nas horas onde a energia é mais barata, poupando combustível para ser queimada nos horários de pico energético.

Os níveis de estoque e atraso (Figura 18) tem variação mais aparente entre os modelos GLSP3 e GLSP4. Na solução do modelo GLSP4, ocorre um leve aumento do atraso nos períodos 1 e 2, enquanto o estoque se mantém bem próximo de zero nos dois períodos. No último período do horizonte, no entanto, os custos tem acentuado aumento, o que gera o crescimento dos custos totais. Estes aumentos de custos indicam que a adição de 

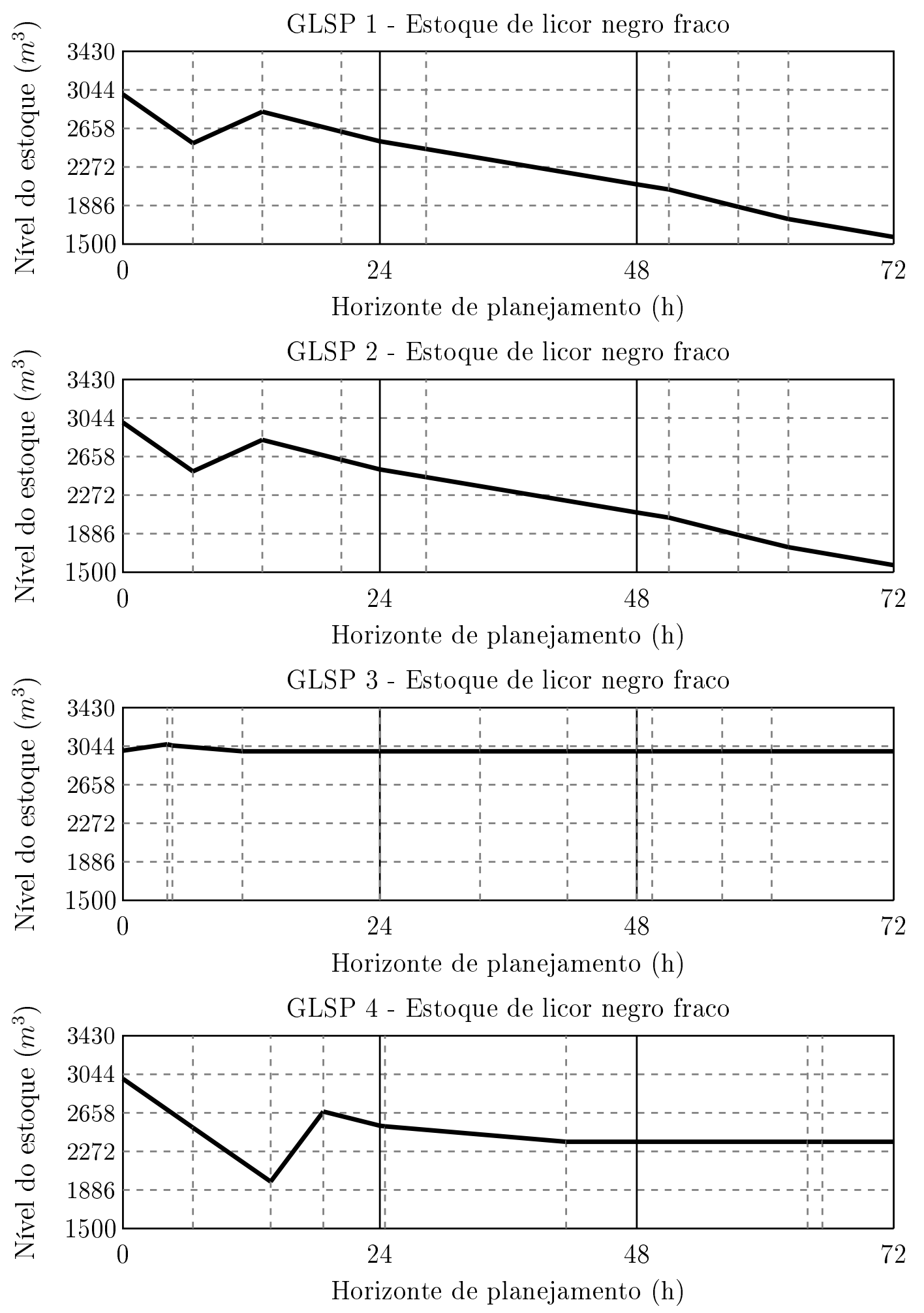

Figura 15: Nível de estoque de licor negro fraco - instância M1.

ciclos de produção mais rígidos diminui a flexibilidade da produção em um horizonte de planejamento de curto prazo. Estudos com horizontes de planejamento maiores se fazem necessários para verificar esta influência a médio e longo prazo. 

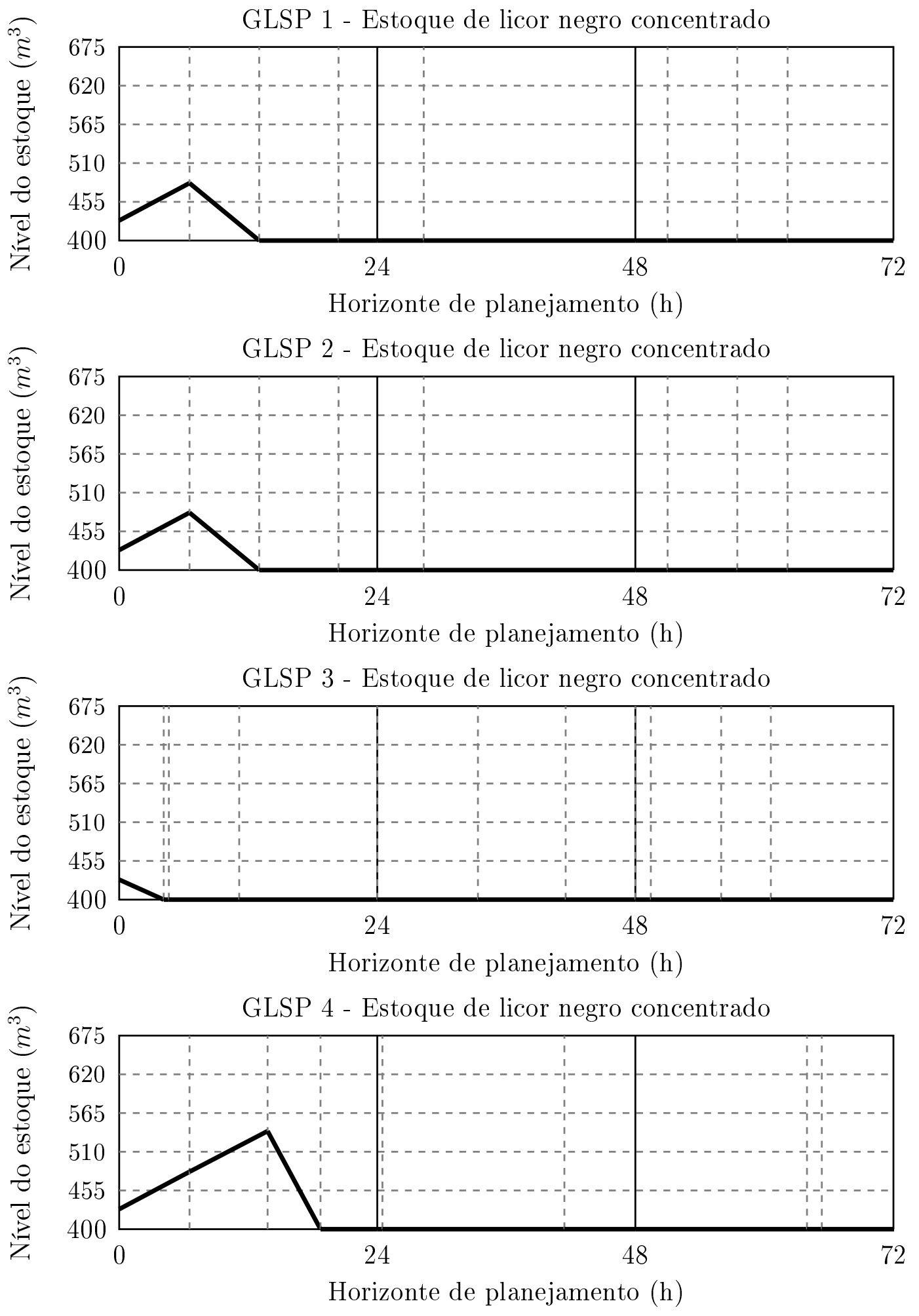

Figura 16: Nível de estoque de licor negro concentrado - instância M1.

As quatro soluções da instância M2, com duas máquinas, têm sequências de velocidades de trabalho idênticas para o digestor (Figura 19). Nos quatro casos, o digestor foi mantido com velocidade constante durante todo o horizonte de planejamento. No entanto, a velocidade poderia ser aumentada, pois os estoques de celulose virgem (Figura 20) e 

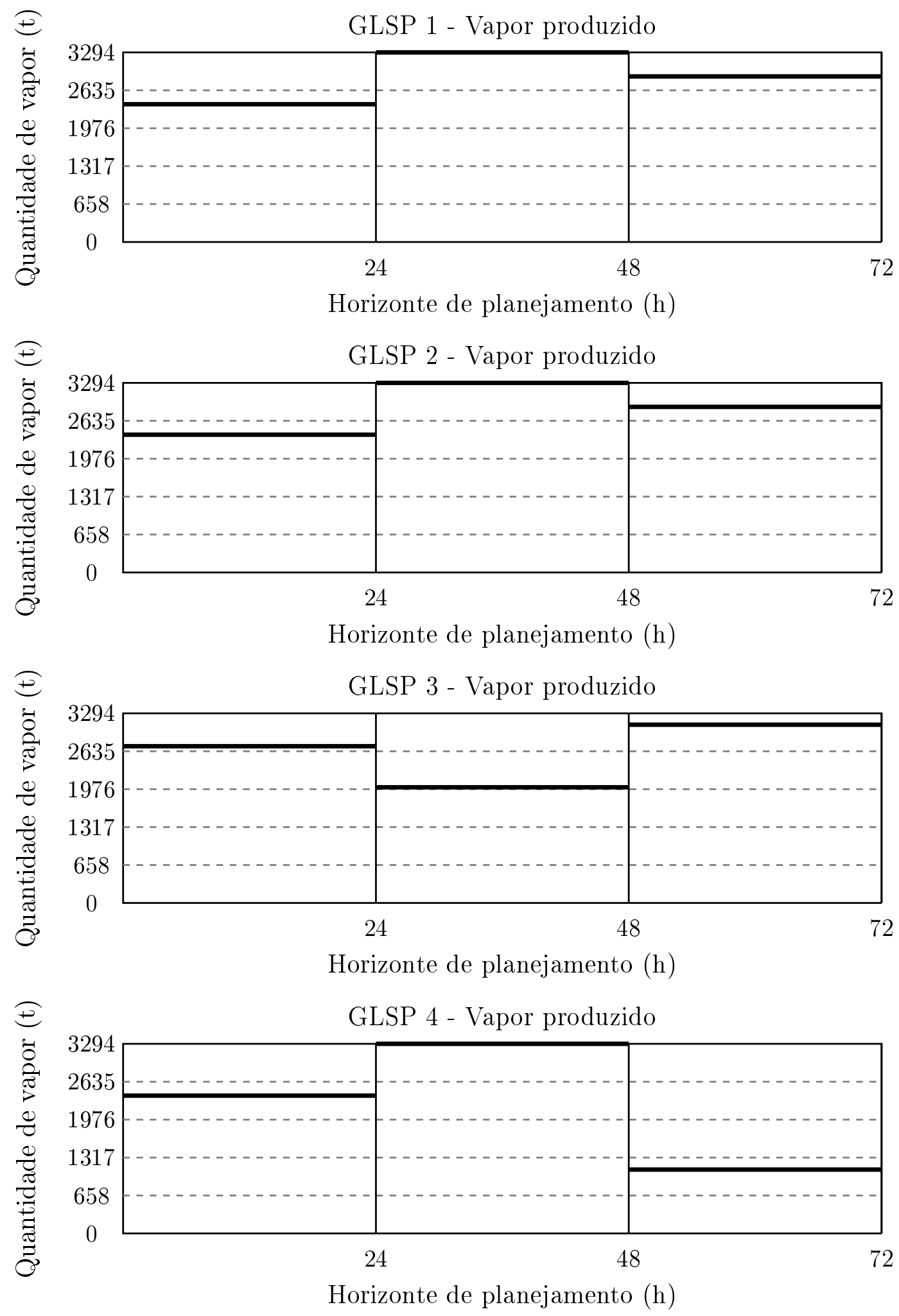

Figura 17: Quantidade de vapor produzido - instância M1.

licor negro fraco (Figura 23) tem capacidade livre para receber produtos.

Os níveis de estoque de celulose virgem se mantiveram baixos durante todo o horizonte de planejamento para as quatro soluções, no entanto, se mantiveram superior ao limite 

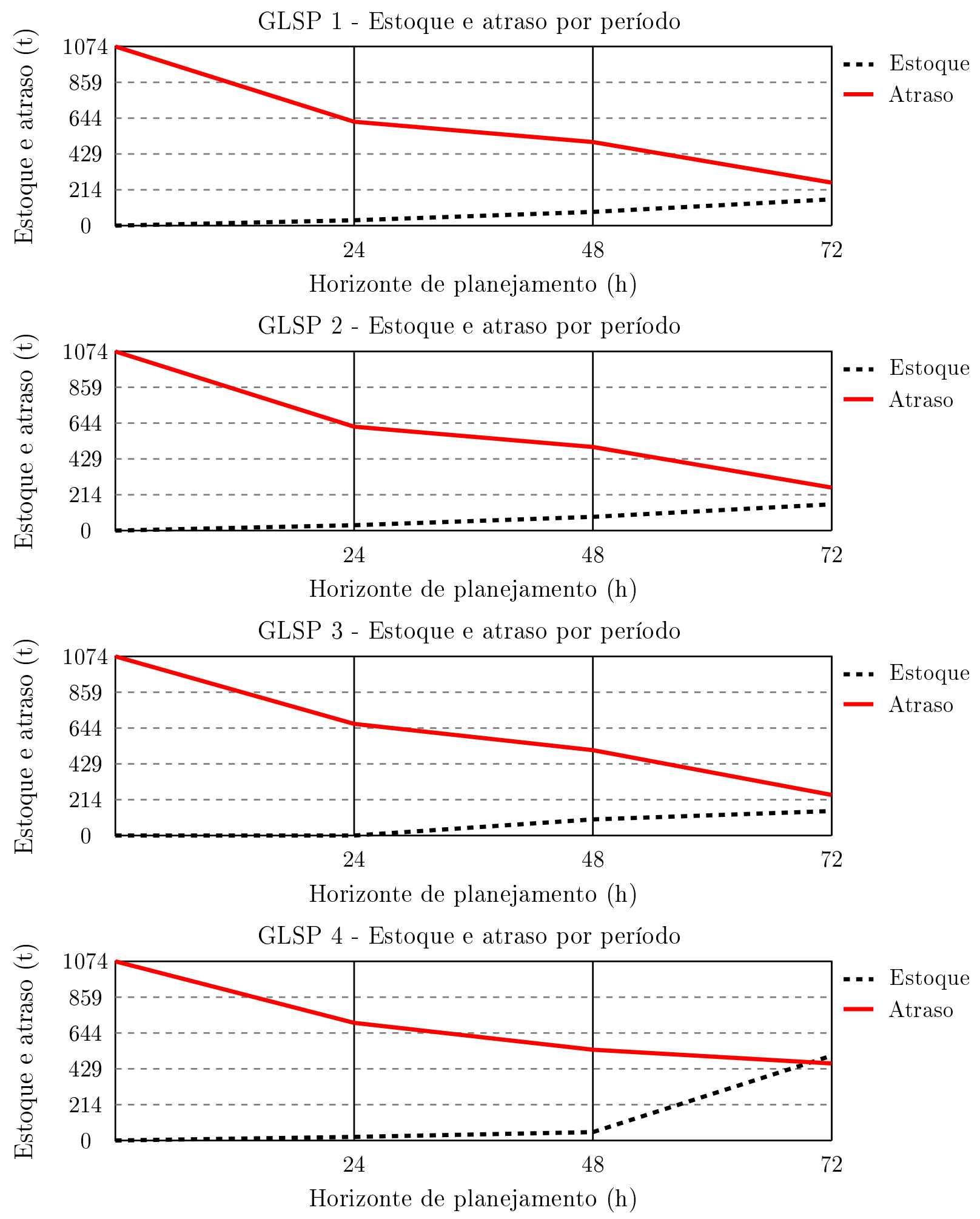

Figura 18: Nível agregado de estoque e atraso de produtos finais - instância M1.

mínimo de estoque, como pode ser visto na Figura 20. Isto mostra que a quantidade de celulose virgem não se apresenta como um gargalo de produção e, portanto, mais celulose virgem poderia ser produzida/estocada se necessária durante um plano de produção de maior duração, pelo menos para esta instância. Esta solução apresenta resultado similar 


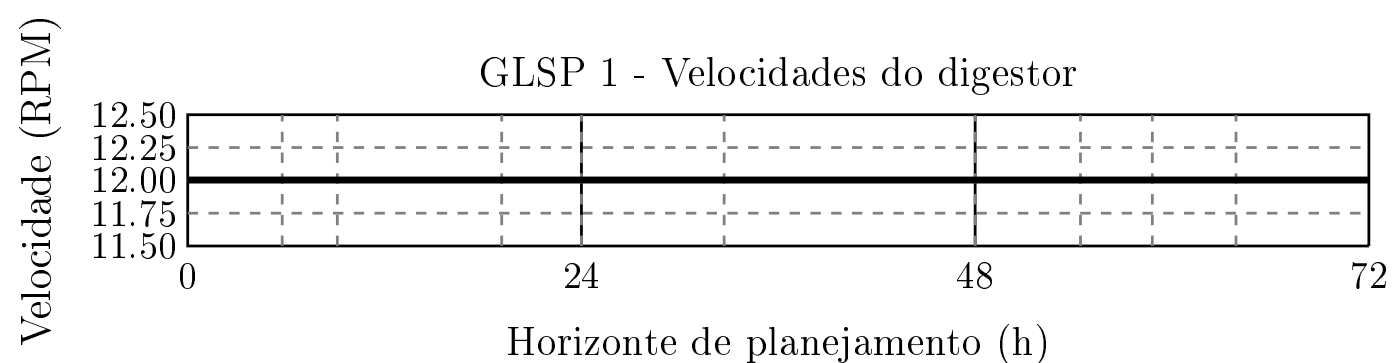

Horizonte de planejamento $(\mathrm{h})$

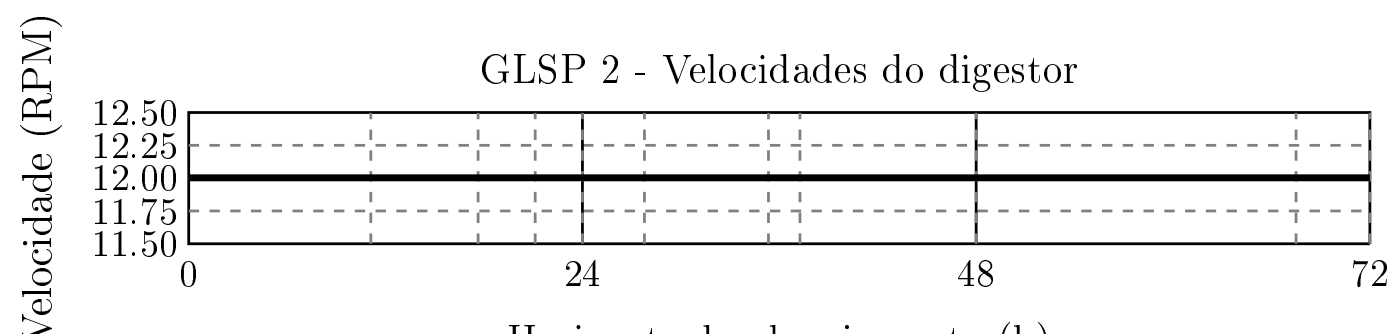

Horizonte de planejamento $(\mathrm{h})$

GLSP 3 - Velocidades do digestor

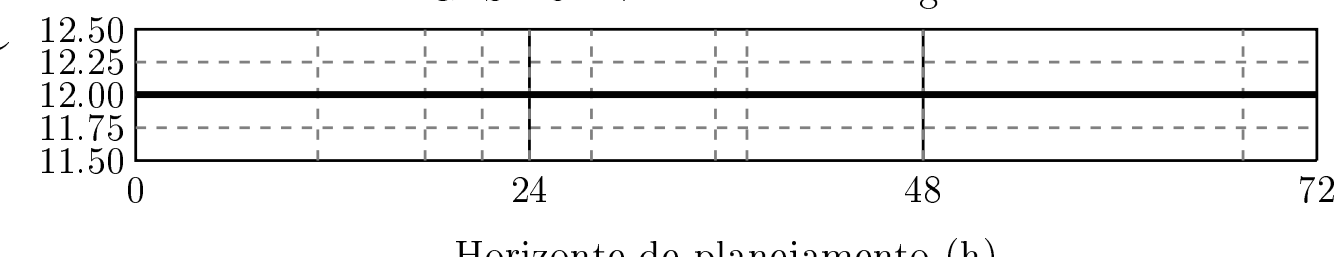

Horizonte de planejamento $(\mathrm{h})$

GLSP 4 - Velocidades do digestor

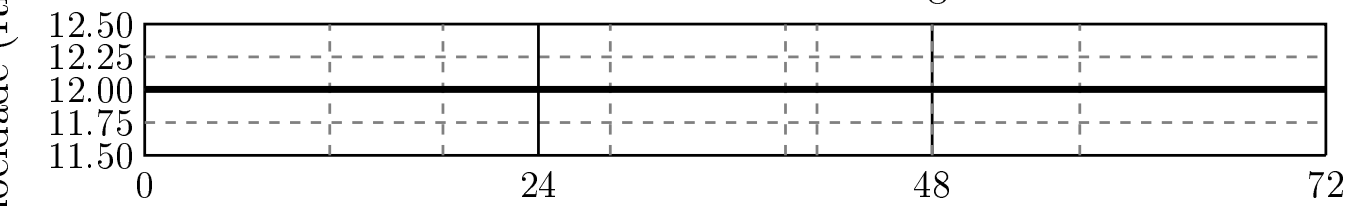

Horizonte de planejamento $(\mathrm{h})$

Figura 19: Sequência de velocidades de trabalho do digestor - instância M2.

ao da instância anterior, o que possibilita a adição de metas de estoque final de produto intermediário também neste caso, se desejável pelo tomador de decisão.

Os planos de produção nas máquinas de papel (Figuras 21 e 22) apresentaram as maiores mudanças entre os resultados de cada modelo matemático, para a instância M2. Enquanto o modelo GLSP1 apresenta produção de algumas gramaturas nas duas máquinas como, por exemplo, $65 \mathrm{~g} / \mathrm{m}^{2}, 100 \mathrm{~g} / \mathrm{m}^{2}$ e $104 \mathrm{~g} / \mathrm{m}^{2}$, os demais modelos tem a divisão das gramaturas por máquina de papel. A divisão foi feita de acordo com a demanda dos produtos, a fim de dividir a carga de trabalho das máquinas de papel (Seção 3.5.3). Enquanto a máquina de papel 1 produz as gramaturas $60 \mathrm{~g} / \mathrm{m}^{2}, 63 \mathrm{~g} / \mathrm{m}^{2}$ e $65 \mathrm{~g} / \mathrm{m}^{2}$, a máquina de papel 2 é responsável pelas demais gramaturas (de $65 \mathrm{~g} / \mathrm{m}^{2}$ até $240 \mathrm{~g} / \mathrm{m}^{2}$ ). A 

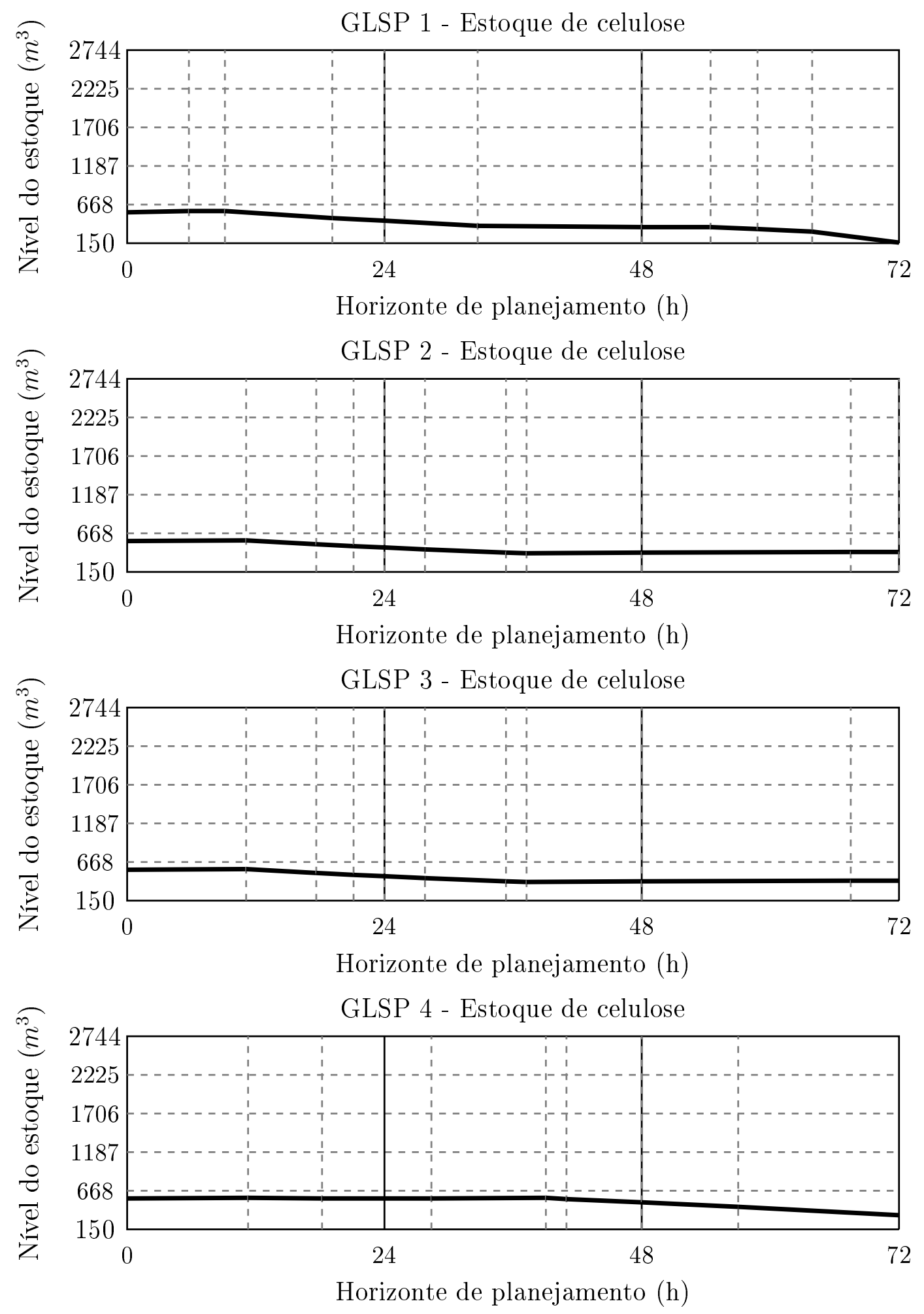

Figura 20: Nível de estoque de celulose virgem - instância M2.

gramatura $65 \mathrm{~g} / \mathrm{m}^{2}$ foi escolhida para ser produzida por ambas as máquinas, para que sua demanda fosse dividida entre ambas as máquinas, a fim de equilibrar a carga de trabalho com mais precisão. Esta divisão provoca a diminuição nos custos de preparação de máquinas, dado que diminui o número de trocas de gramatura. Em contrapartida, a divisão de 
carga gera uma diminuição da flexibilidade e algumas vezes aumenta significativamente os custos de atraso e estoque de determinadas gramaturas, caso a demanda desta esteja muito concentrada. A demanda concentrada pode requisitar, por exemplo, que todas as máquinas disponíveis produzam um mesmo item nos períodos de sua maior demanda.

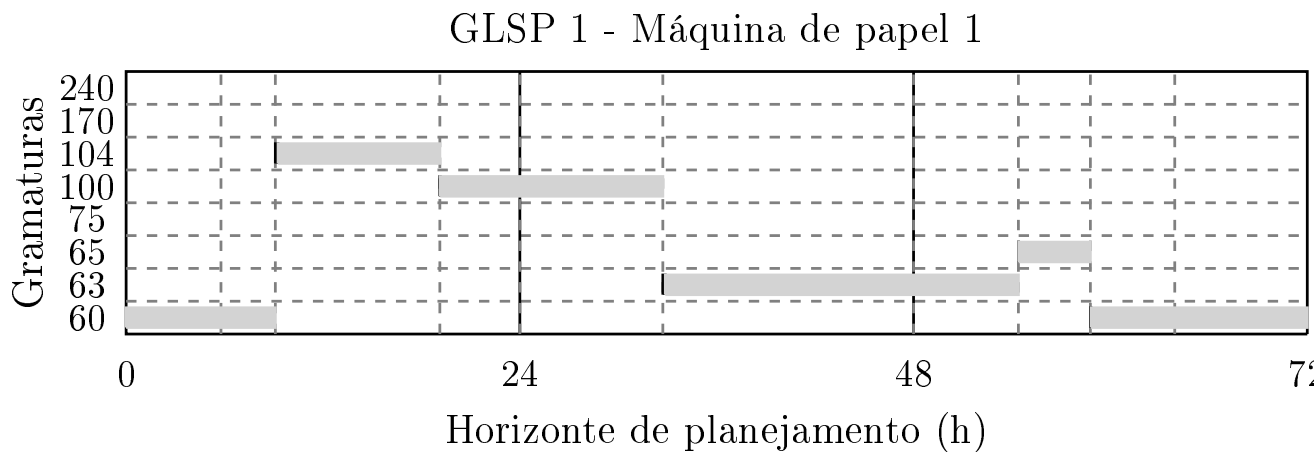

Setup

Produção

GLSP 2 - Máquina de papel 1

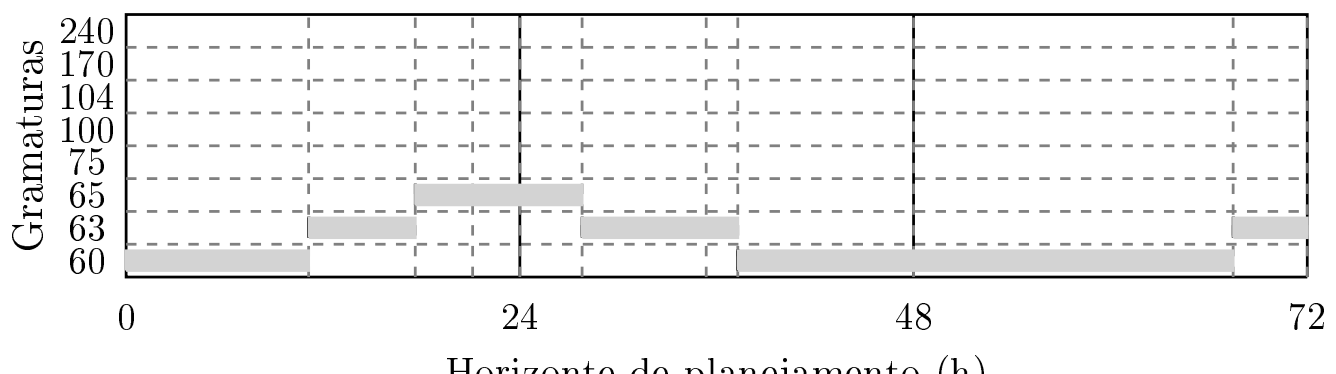

Setup

Produção

Horizonte de planejamento $(\mathrm{h})$

GLSP 3 - Máquina de papel 1

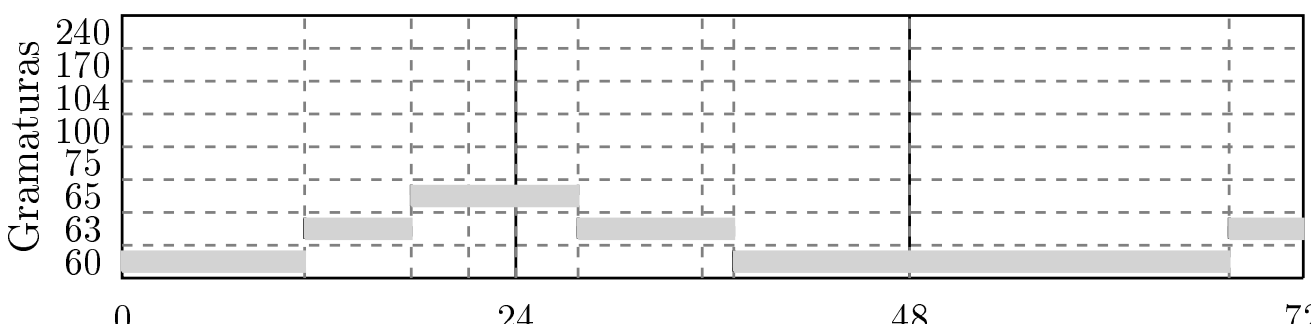

Setup

Produção

Horizonte de planejamento (h)

GLSP 4 - Máquina de papel 1

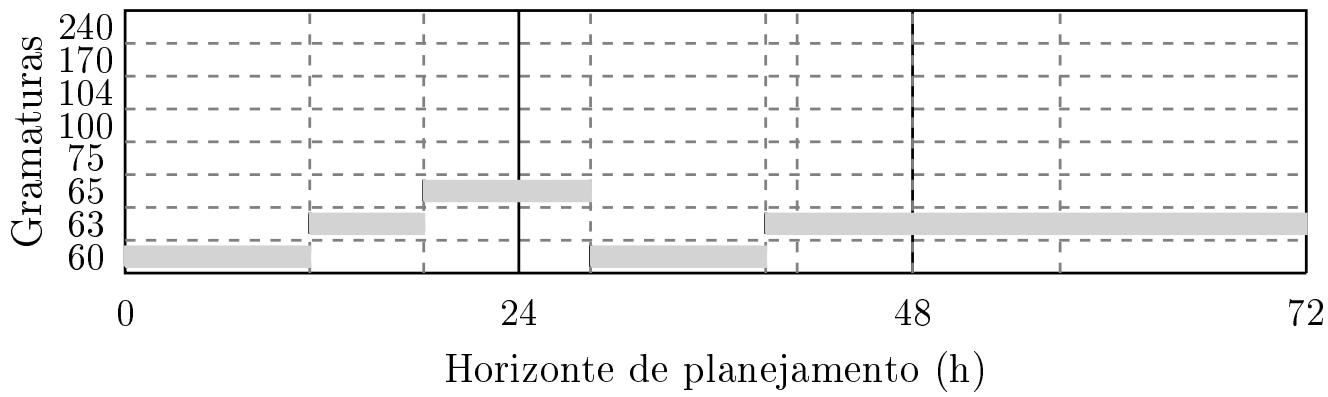

Setup

Produção

Figura 21: Sequência de produção ótima para a primeira máquina de papel - instância M2.

Ainda de acordo com as Figuras 21 e 22, a limitação nas trocas bruscas (GLSP3) não 
GLSP 1 - Máquina de papel 2

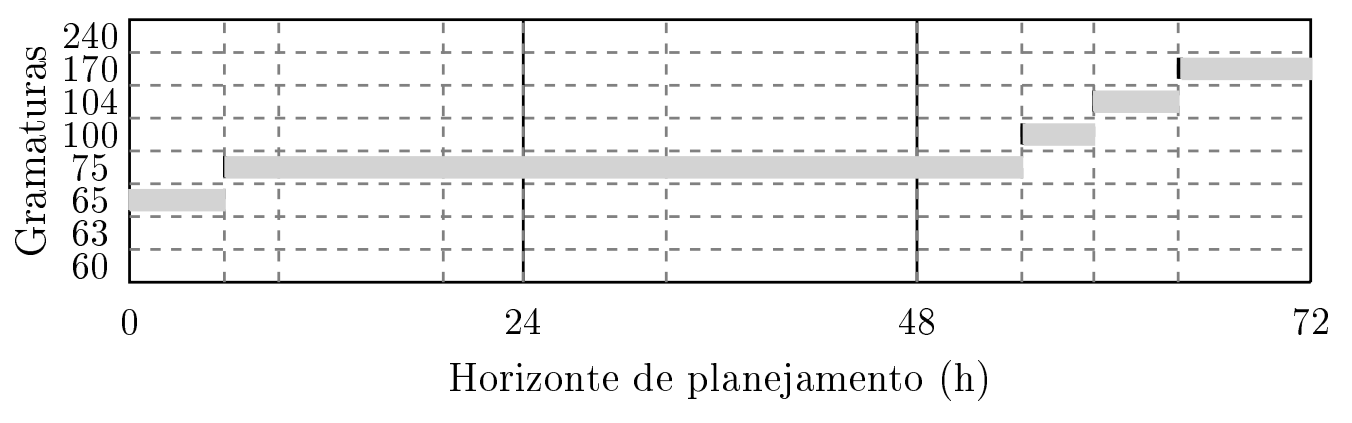

Setup

Produção

GLSP 2 - Máquina de papel 2

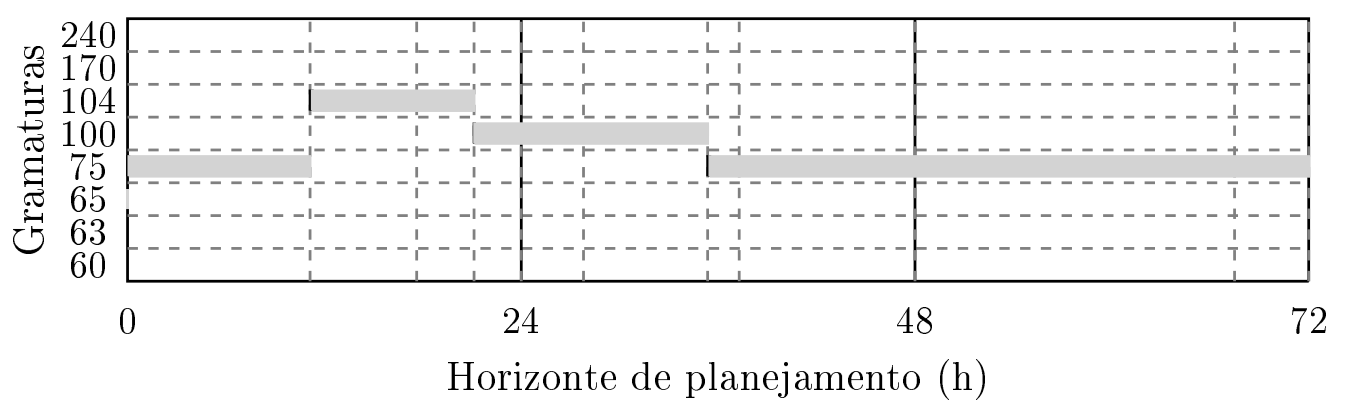

Setup

Produção

GLSP 3 - Máquina de papel 2

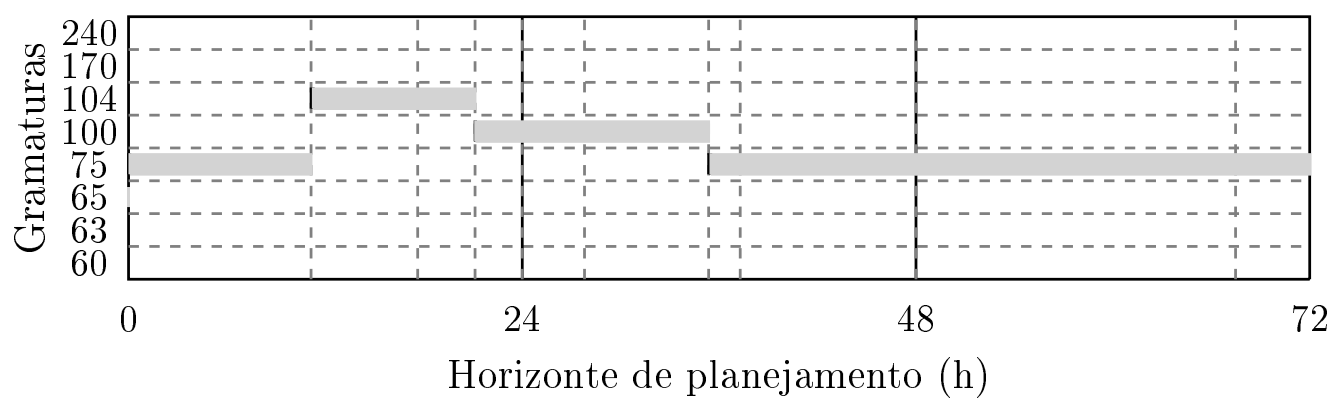

Setup

Produção

GLSP 4 - Máquina de papel 2

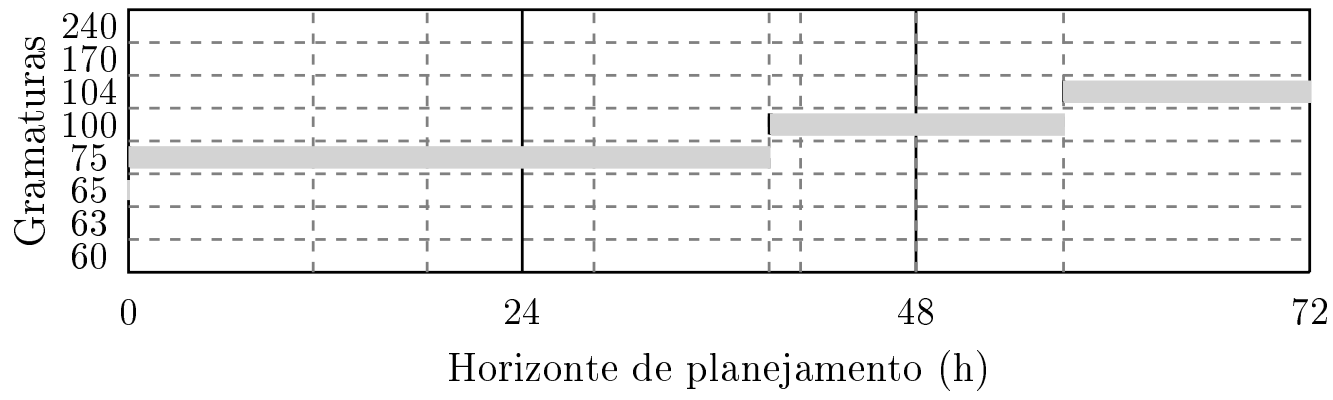

Setup

Produção

Figura 22: Sequência de produção ótima para a segunda máquina de papel - instância M2.

gerou mudanças na solução ótima do problema, pois a solução do modelo GLSP3 já atendia a estas restrições. O modelo GLSP4, por outro lado, gerou mudanças significativas, pois obrigou a mudança no ciclo de produção da máquina de papel 2, alterando também o sequenciamento da produção da máquina de papel 1. Como o horizonte de planejamento é curto, na maioria dos casos não é vantajoso produzir as gramaturas $170 \mathrm{~g} / \mathrm{m}^{2}$ e $240 \mathrm{~g} / \mathrm{m}^{2}$, 
devido ao alto custo de preparação de máquina. No caso analisado, se torna mais vantajoso pagar os custos de estoque dos produtos não demandados e os custos de atraso na entrega dos produtos demandados, ao invés de produzi-los. Isto ocorre principalmente no caso do modelo GLSP4, onde se torna obrigatório a chegada a gramatura $240 \mathrm{~g} / \mathrm{m}^{2}$ para encerrar o processo de subida do ciclo produtivo da máquina de papel 2. Quanto o horizonte de planejamento aumenta, os custos associados a esta prática também aumentam, pois existe um número maior de períodos onde serão cobrados custos de estoque e atraso. Desta forma, para exemplares de teste mais realistas (acima de 7 dias de planejamento), as parcelas dos custos se tornam mais equilibradas, reduzindo a atratividade destas soluções.

Os estoques de licor negro fraco (Figura 23) apresentam nível mínimo na maior parte do horizonte e tem características bem similares entre si. Como os níveis iniciais e finais são iguais e a soma da produção é a mesma durante o horizonte de planejamento (dada pela velocidade de trabalho do digestor da Figura 19), podemos garantir que são soluções equivalentes, pois foi consumido a mesma quantidade de licor negro fraco durante o horizonte de planejamento.

Os estoques de licor negro concentrado das soluções apresentadas na Figura 24 se comportam da mesma forma. As soluções equivalem entre si e apressem consumo ligeiramente superior à produção. Isso indica que a caldeira de recuperação tem capacidade ociosa com relação a entrada de matéria-prima na linha produção (licor negro fraco).

A folga na capacidade produtiva da caldeira de recuperação também pode ser verificado pelos resultados da Figura 25, pois a produção de vapor se encontra abaixo do limite produtivo $\left(6588 \mathrm{~m}^{3} /\right.$ dia ou $\left.275,5 \mathrm{~m}^{3} / \mathrm{h}\right) \mathrm{em}$, ao menos, um período por solução para todos os modelos.

Os atrasos no atendimento da demanda e o nível de estoque são visivelmente afetados pela divisão das gramaturas por máquina de papel (Figura 26). A maior mudança se encontra nos níveis de estoque e atraso do último período do horizonte de planejamento. Os gastos adicionais são gerados principalmente a partir da não produção da gramatura $170 \mathrm{~g} / \mathrm{m}^{2}$ no terceiro período do horizonte de planejamento, nos modelos GLSP2, GLSP3 e GLSP4.

Os resultados computacionais demonstram as diferenças e dificuldades adicionadas encontrados com a imposição das restrições adicionais, geradas com base em práticas verificadas nas empresas deste setor produtivo. Do ponto de vista de desenvolvimento do plano de produção por um especialista do setor, elas facilitam a construção e adaptação dos planos produtivos em futuros ciclos de produção. Do ponto de vista de modelagem, 

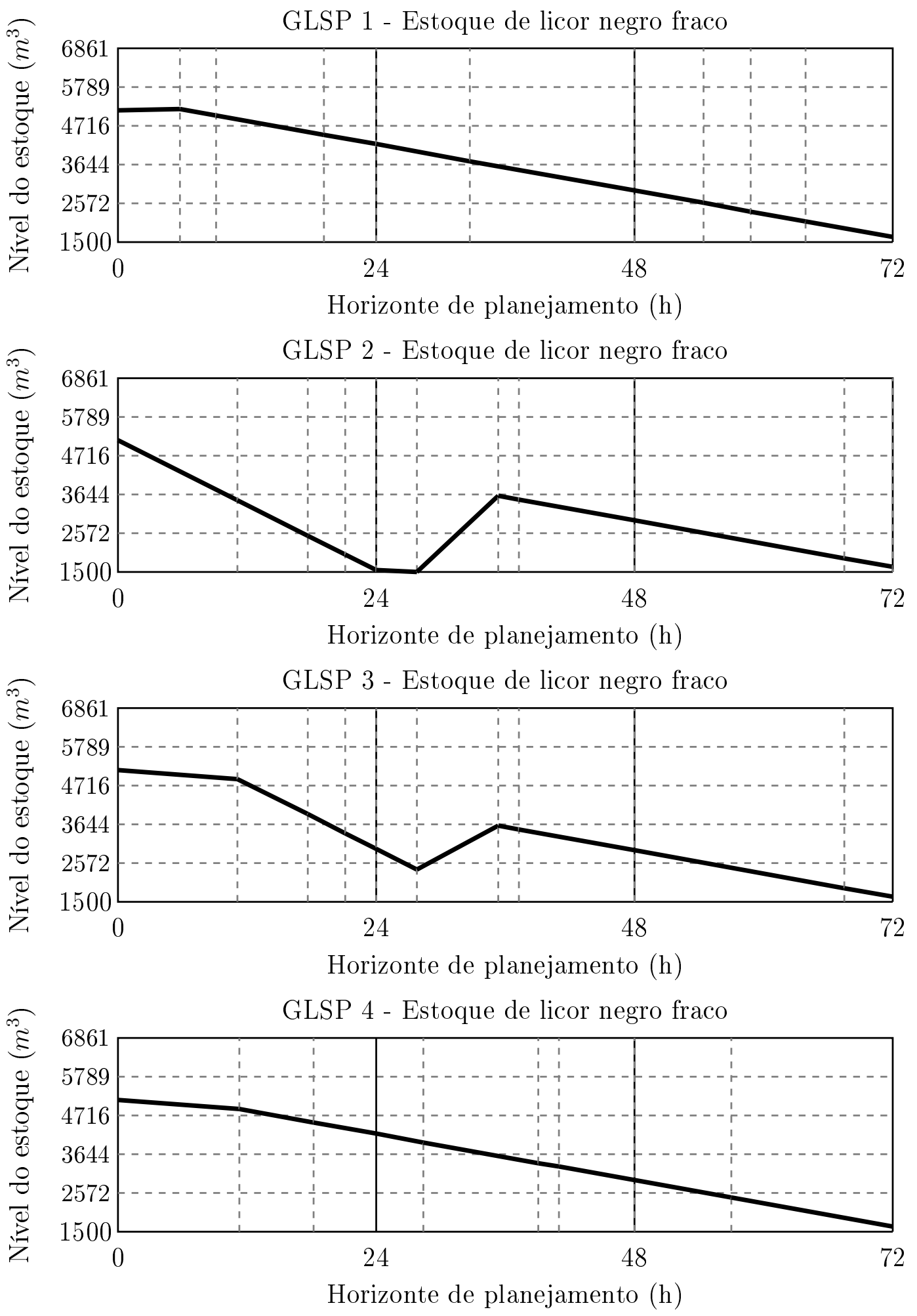

Figura 23: Nível de estoque de licor negro fraco - instância M2.

reduzem o espaço de soluções factíveis do problema, no entanto, esta redução ocasionou piora na função objetivo do problema para os exemplares de teste analisados (com horizonte de planejamento de 3 dias). Tendo em vista que as três práticas analisadas tendem a agregar as demandas de períodos consecutivos para gerar planos de produção 

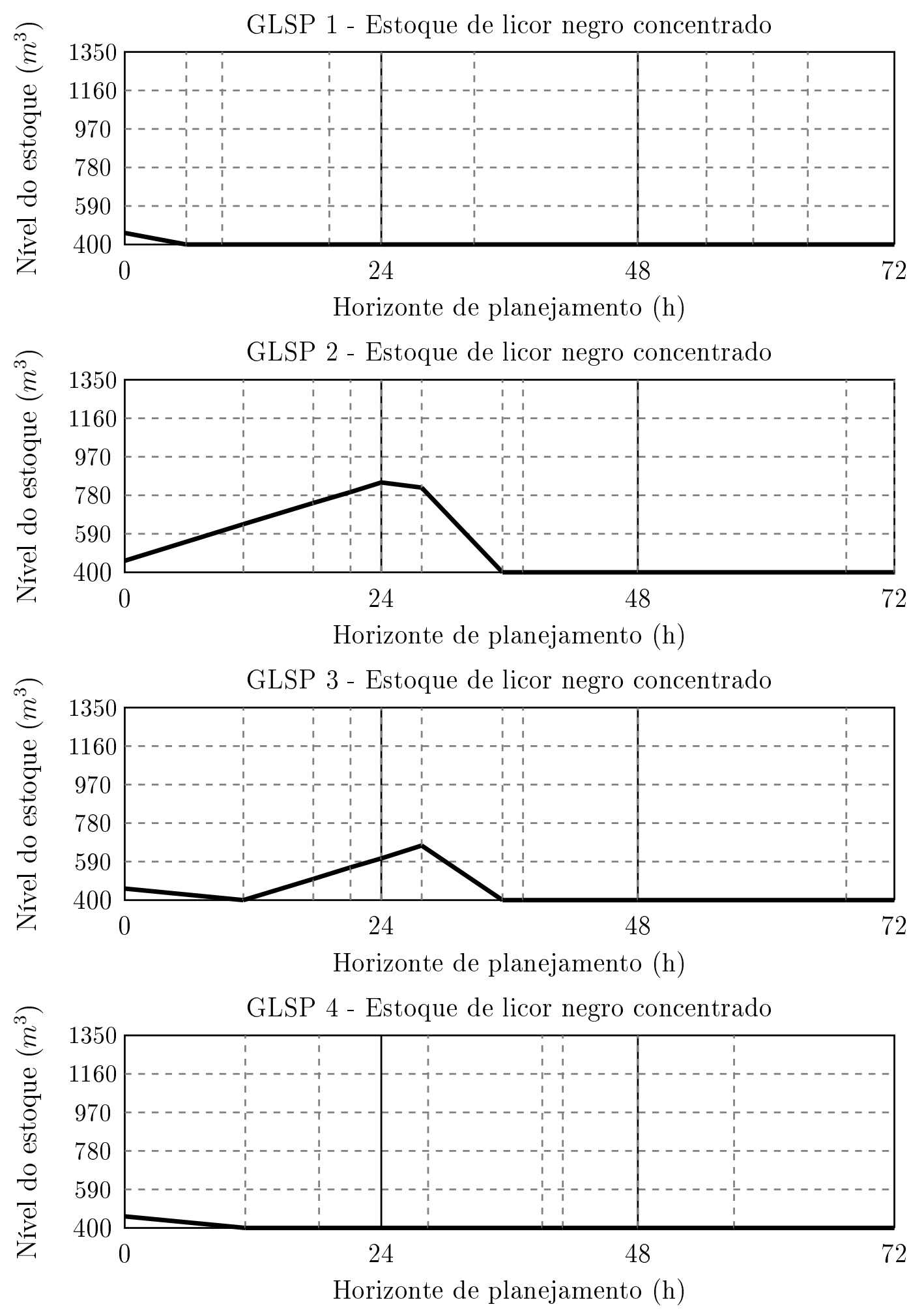

Figura 24: Nível de estoque de licor negro concentrado - instância M2.

mais "suaves", pode ser que em exemplares de teste mais realistas (com horizontes de planejamento maiores), as perdas na função objetivo sejam mitigadas pela aumento da demanda resultante destes horizontes de planejamento mais extensos. 

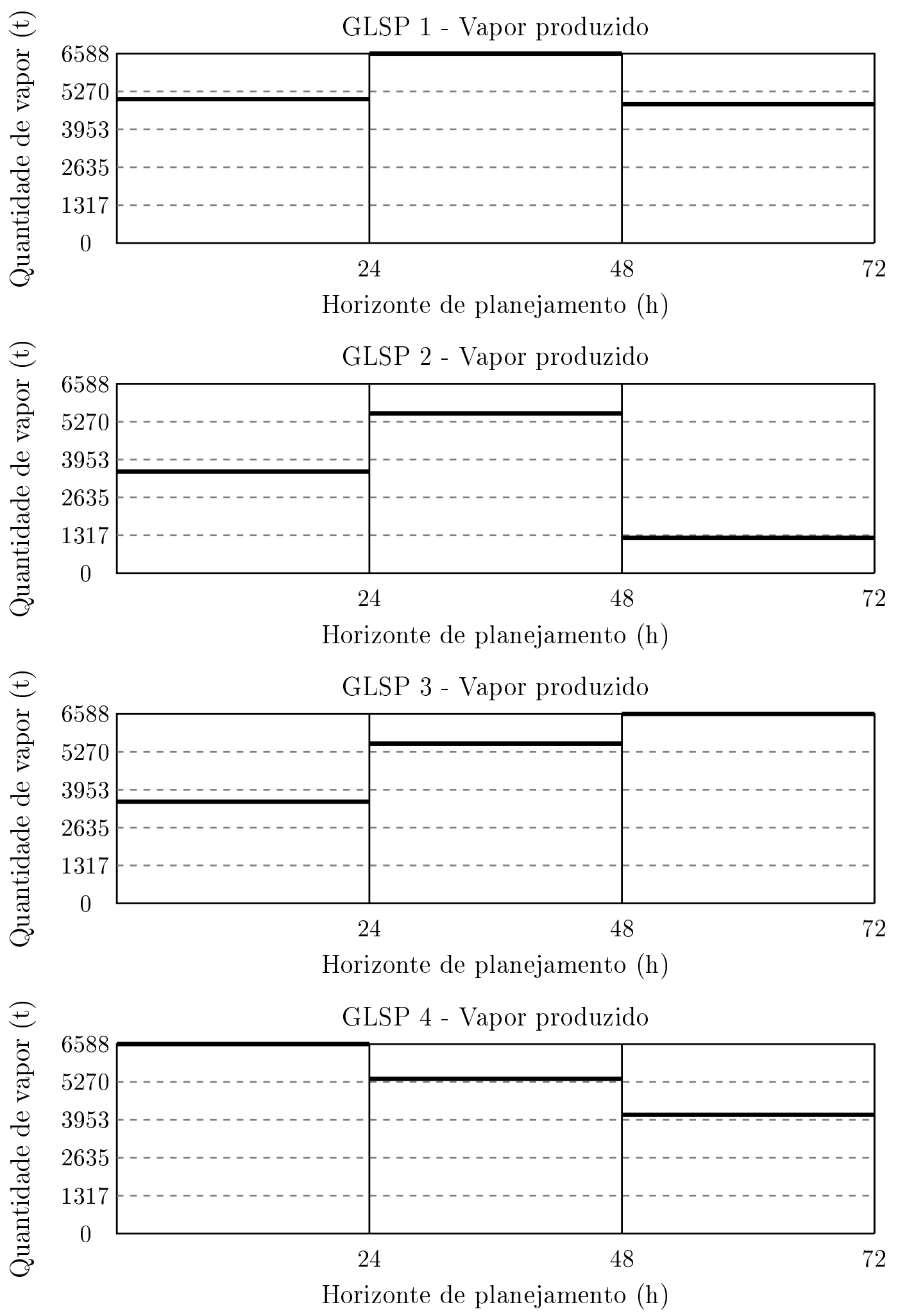

Figura 25: Quantidade de vapor produzido - instância M2.

Por outro lado, as restrições adicionais podem gerar regras simples de construção de soluções, que são um bom ponto de partida para a criação de heurísticas construtivas para a resolução do problema. Um exemplo disso é a heurística construtiva desenvolvida em 

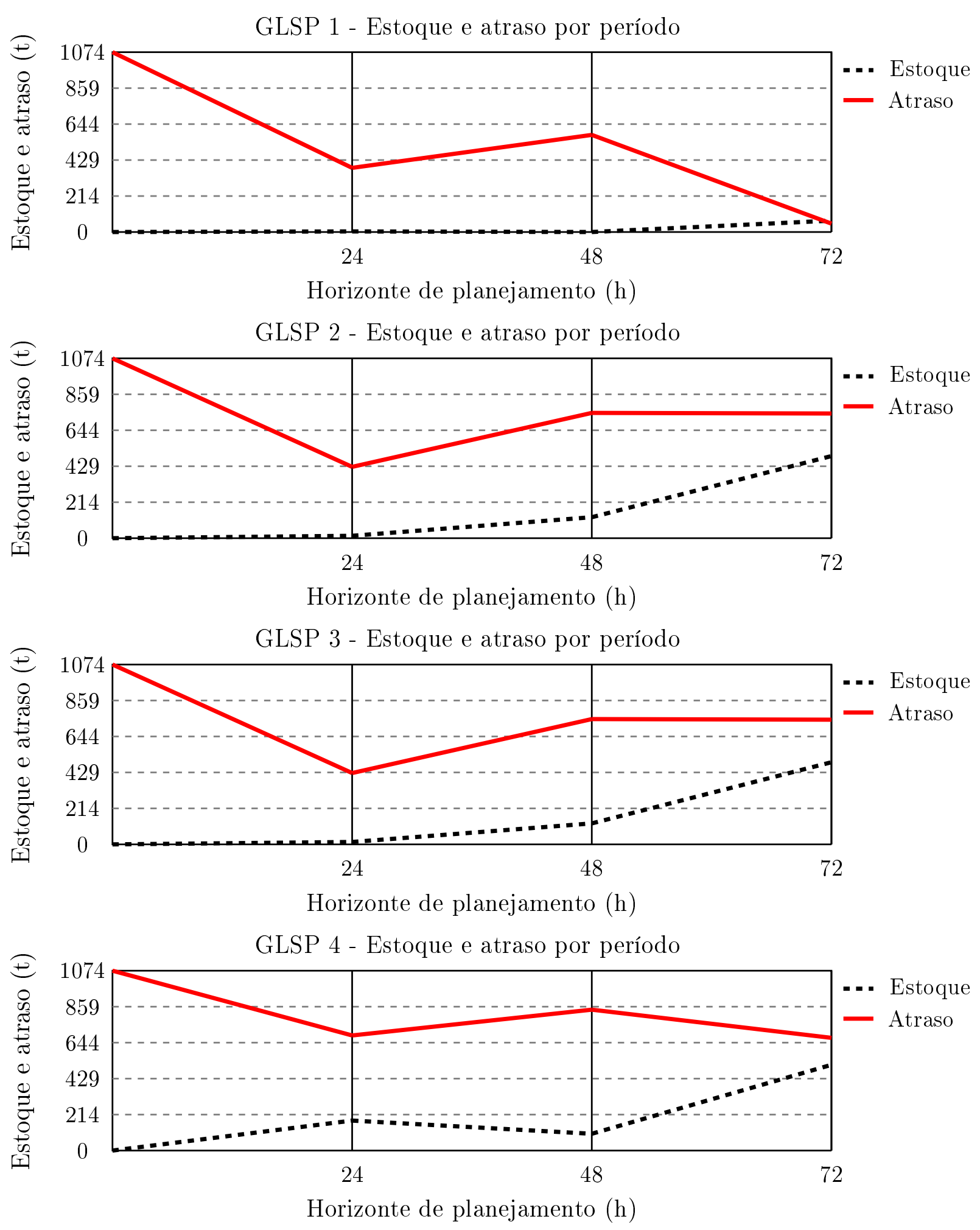

Figura 26: Nível agregado de estoque e atraso de produtos finais - instância M2.

Figueira et al. (2013), que gera ciclos de produção e define as produções e demais variáveis do problema a partir destes ciclos produtivos. Esta e outras heurísticas construtivas e de melhoria aqui desenvolvidas para resolução do problema estudado são apresentadas no Capítulo 4. 


\section{Heurísticas construtivas e de melhoria}

Este capítulo apresenta quatro heurísticas construtivas e duas heurísticas de melhoria desenvolvidas e adaptadas para resolver o problema em estudo. Destas abordagens desenvolvidas, três são heurísticas construtivas simples. A quarta abordagem construtiva é um método do tipo relaxe-e-fixe (relax-and-fix). As duas heurísticas de melhoria desenvolvidas têm como base o método fixe-e-otimize (fix-and-optimize).

A primeira heurística construtiva se baseia em alocação gulosa dos papéis que serão produzidos em cada micro-período do horizonte de planejamento. Após a definição do sequenciamento das máquinas de papel, as quantidades produzidas dos papéis e consumida de celulose são definidas. Esta definição é possível a partir da definição de micro-períodos de tamanho fixo e, neste caso, iguais. Um procedimento iterativo tenta definir as velocidades de funcionamento do digestor para que o problema se torne factível. Se for possível, o processo retorna a solução encontrada. Caso contrário, um procedimento de factibilização é executado para tentar ajustar o sequenciamento das máquinas de papel, para que uma solução factível possa ser encontrada. Mais detalhes desta heurística são apresentados na Seção 4.1.

A segunda heurística construtiva foi adaptada a partir de um procedimento construtivo apresentado em Furlan et al. (2015), no qual foi adicionado um passo de factibilização da solução. Este procedimento usa os resultados da relaxação linear das variáveis para estimar probabilidades de escolha de cada gramatura para ser produzida em cada microperíodo. A Seção 4.2 apresenta esta abordagem e seu procedimento de factibilização.

A terceira heurística construtiva é uma simples adaptação da abordagem construtiva proposta por Figueira et al. (2013). Esta heurística se baseia na definição a priori de ciclos de produção, que são utilizados para definir a sequência de alocação das gramaturas a serem produzidas em cada micro-período do horizonte de planejamento. A Seção 4.3 
apresenta a heurística construtiva baseada em ciclos predefinidos de produção.

A heurística do tipo relaxe-e-fixe desenvolvida se utiliza de particionamento simultâneo das variáveis de sequenciamento de velocidade dos digestores e das gramaturas nas máquinas de papel. Foram desenvolvidas cinco formas de particionamento das variáveis de controle do digestor e outras oito formas de particionamento das variáveis de sequenciamento das máquinas de papel. Para cada combinação de partições testadas, foram averiguadas três parametrizações distintas. A descrição da heurística relaxe-e-fixe, bem como as formas de particionamento utilizadas, são apresentados na Seção 4.4

As duas heurísticas de melhoria foram construídas com base no método fixe-e-otimize (fix-and-optimize). Estes métodos tem como base a modelagem matemática do problema, pois se utilizam do particionamento do problema e da resolução iterativa de sub-problemas fixados com o uso de uma ferramenta de solução exata. A primeira fixe-e-otimize foi construída da forma tradicional, tal qual definida em Buschkühl et al. (2010). Na segunda variante, foram feitas modificações que visam tomar proveito da estrutura multi-nível do problema abordado. As duas variações de fixe-e-otimize desenvolvidas e as formas de particionamento utilizadas são apresentadas na Seção 4.5.

\subsection{Heurística construtiva gulosa}

Uma heurística construtiva gulosa tem por objetivo gerar soluções rapidamente e que sejam, pelo menos parcialmente, de boa qualidade. Estas são heurísticas também conhecidas como "míopes", por resolverem o problema por passos da melhor forma possível em cada passo sem se preocupar com os passos futuros. Isto gera soluções de alta qualidade inicial, no entanto, tende a construir soluções globais pouco eficientes, pois deixa para os últimos passos as tarefas mais problemáticas (REINELT, 1994).

Um exemplo clássico de heurística construtiva gulosa é a heurística do vizinho mais próximo, utilizada para gerar soluções iniciais em problemas como o problema do caixeiro viajante (TSP) (REINELT, 1994). Neste caso, considerando a representação do problema por um grafo, dado um vértice inicial, a heurística escolhe sempre o vizinho mais próximo ao nó atual para ser visitado pelo caixeiro viajante na sequência. No último passo, a heurística junta o nó final com o nó inicial, gerando assim o ciclo a ser percorrido pelo caixeiro viajante. Nos últimos passos, as distâncias podem se tornar cada vez mais longas, pois a heurística não se preocupa com o percurso todo, mas apenas com a menor distância a cada passo. 
Cabe ressaltar aqui que em alguns casos específicos algoritmos gulosos têm garantia de otimalidade da solução. Para que um algoritmo guloso tenha garantia de otimalidade é necessário que o problema tenha duas características, sendo elas: sub-estrutura ótima e propriedade de escolha gulosa. A sub-estrutura ótima significa que uma solução ótima para partes do problema (sub-problemas) faz parte de ao menos uma solução ótima para o problema original. Desta forma, pode-se particionar o sub-problema e combinar as soluções ótimas destes sub-problemas a fim de obter uma solução ótima para o problema que está sendo resolvido. A propriedade de escolha gulosa diz respeito a possibilidade de construirmos um método que iterativamente toma a decisão gulosa e acaba gerando uma solução ótima para o problema original. Nenhuma das duas características se verifica no caso do problema estudado, eliminando a garantia de otimalidade da solução. No entanto, a heurística gulosa desenvolvida ainda pode gerar resultados de alta qualidade em tempo computacional razoável. Isto torna a heurística atrativa para combinações em métodos de solução mais complexos. Mais detalhes sobre algoritmos gulosos podem ser encontrados em Cormen et al. (2009).

A heurística construtiva gulosa parte da ordenação das gramaturas pelo valor monetário da tonelada da gramatura $\left(\right.$ price $\left._{j}\right)$, dividido pela taxa de produção da mesma $\left(b_{j}\right)$. Desta forma, saberemos o valor gerado ao produzir esta gramatura a cada hora $\left(r p_{j}\right)$. Os preços da tonelada de cada gramatura seguem a média do preço da carteira de pedidos, como apresentado na Seção 3.5.1. O Algoritmo 4.1 apresenta um pseudo-código desta heurística construtiva. Na Linha 1 , as gramaturas são ordenadas pelo valor de $r p_{j}$ de forma decrescente e as alocações ocorrem de acordo com a demanda $D_{j}$ (linhas entre 2 e 15). Como os custos de atraso e de estoque são calculados a partir do preço das gramaturas, espera-se que alocar a demanda das gramaturas mais caras antes pode gerar um custo total menor. Por outro lado, esta prática não leva em consideração a redução nos custos de preparação de máquina, podendo gerar altos custos nesta parcela da função objetivo. Uma heurística gulosa de re-sequenciamento é usada para reduzir este custo de produção (Linha 16). Esta heurística também é usada em Furlan et al. (2015), sobre o conjunto de soluções iniciais.

As velocidades do digestor são definidas por meio de uma heurística recursiva (Linha 17), que tenta determinar uma sequência de velocidades capaz de atender as demandas de celulose virgem da máquina de papel e que atenda as demandas de consumo, respeitando os limites de estocagem de celulose virgem e licor negro fraco. Caso não seja possível encontrar um conjunto de velocidades que atenda essas condições, uma heurística de factibilização é executada (linhas entre 21 e 30). Esta heurística troca algumas gramaturas 


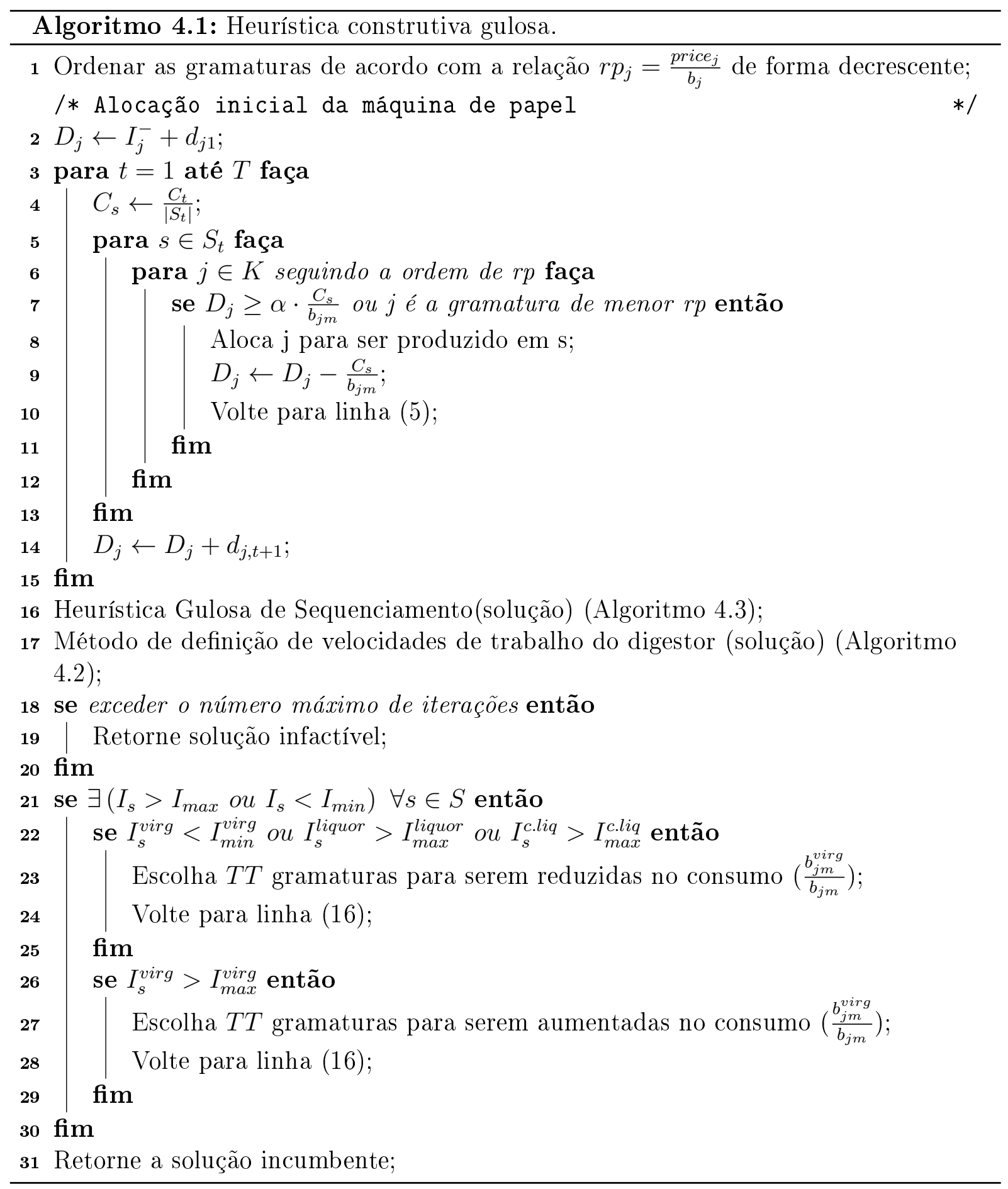

alocadas, com o intuito de diminuir ou aumentar o consumo de celulose virgem, dependendo do limite de capacidade que está sendo violado. Quando o estoque de celulose torna-se baixo (Linha 22), gramaturas com alta taxa de consumo de celulose são aleatoriamente escolhidas e trocadas por gramaturas com taxa menor de consumo. No caso de violações do estoque máximo de celulose (Linha 26), as gramaturas de taxa de consumo menor são trocadas por opções com maior taxa de consumo. 
Para reduzir o tempo computacional exigido pelo método, foi feita uma simplificação no problema tratado. A simplificação consiste em desconsiderar os micro-períodos de tamanho variável definidos pelo modelo GLSP e considera-los fixos e de tamanho igual. Este procedimento é feito na Linha 4 , na qual $C_{t}$ representa o tamanho do período e $\left|S_{t}\right|$ indica a quantidade de micro-períodos pertencentes a $t$. Por exemplo, em um período com capacidade igual a 24 horas (1 dia) que tenha 4 micro-períodos, cada micro-período terá 6 horas. Esta simplificação gera soluções que são factíveis no problema original, no entanto, pode deteriora-las devido a redução de flexibilidade. A simplificação foi utilizada para evitar que fosse necessário a solução de um sub-problema linear gerado pelas variáveis de dimensionamento de lotes do problema. Com tamanhos de micro-período conhecidos a priori e a obrigação de uso de todo micro-período, pode-se definir por meio de um simples procedimento as quantidades produzidas de matérias-primas e produtos finais, bem como o consumo de insumos e níveis de estoque.

Além dos dados do problema, a heurística necessita de um ajuste no parâmetro $\alpha$, que define a relação mínima entre a demanda e a quantidade produzida no micro-período (Linha 7). Esta comparação indica qual a demanda mínima exigida para que seja possível produzir determinada gramatura em relação ao tamanho total do micro-período. Uma gramatura $i$ é alocada para ser produzida sempre que a demanda acumulada de $i$ for superior ao mínimo $\alpha$ do tamanho do micro-período. Caso contrário, passa-se para a gramatura seguinte de acordo com a ordenação de rp.

\subsubsection{Método de definição de velocidades de trabalho do digestor}

A velocidade de trabalho do digestor é definida de forma iterativa, seguindo o horizonte de planejamento do início para o final. O processo retorna alguns micro-períodos quando ocorrem trocas nas velocidades, dado que existe um limite máximo $\Delta$ na troca entre as velocidades de micro-períodos sub-sequentes. Quando o limite de algum estoque é violado, o processo retorna nos micro-períodos anteriores, verificando a possibilidade de reduzir ou aumentar a velocidade de trabalho do digestor, dependendo da necessidade. O Algoritmo 4.2 apresenta o pseudo-código do método de definição da velocidade de trabalho do digestor.

Na Linha 1 é feita a alocação inicial da velocidade inicial do digestor em cada microperíodo $\left(v_{s}\right)$, utilizando a velocidade inicial como referência $\left(v_{0}\right)$. Na Linha 2 são calculados os níveis dos tanques de celulose virgem, licor negro fraco e licor negro concentrado, a partir da velocidade do digestor e gramaturas das máquinas de papel em cada micro- 


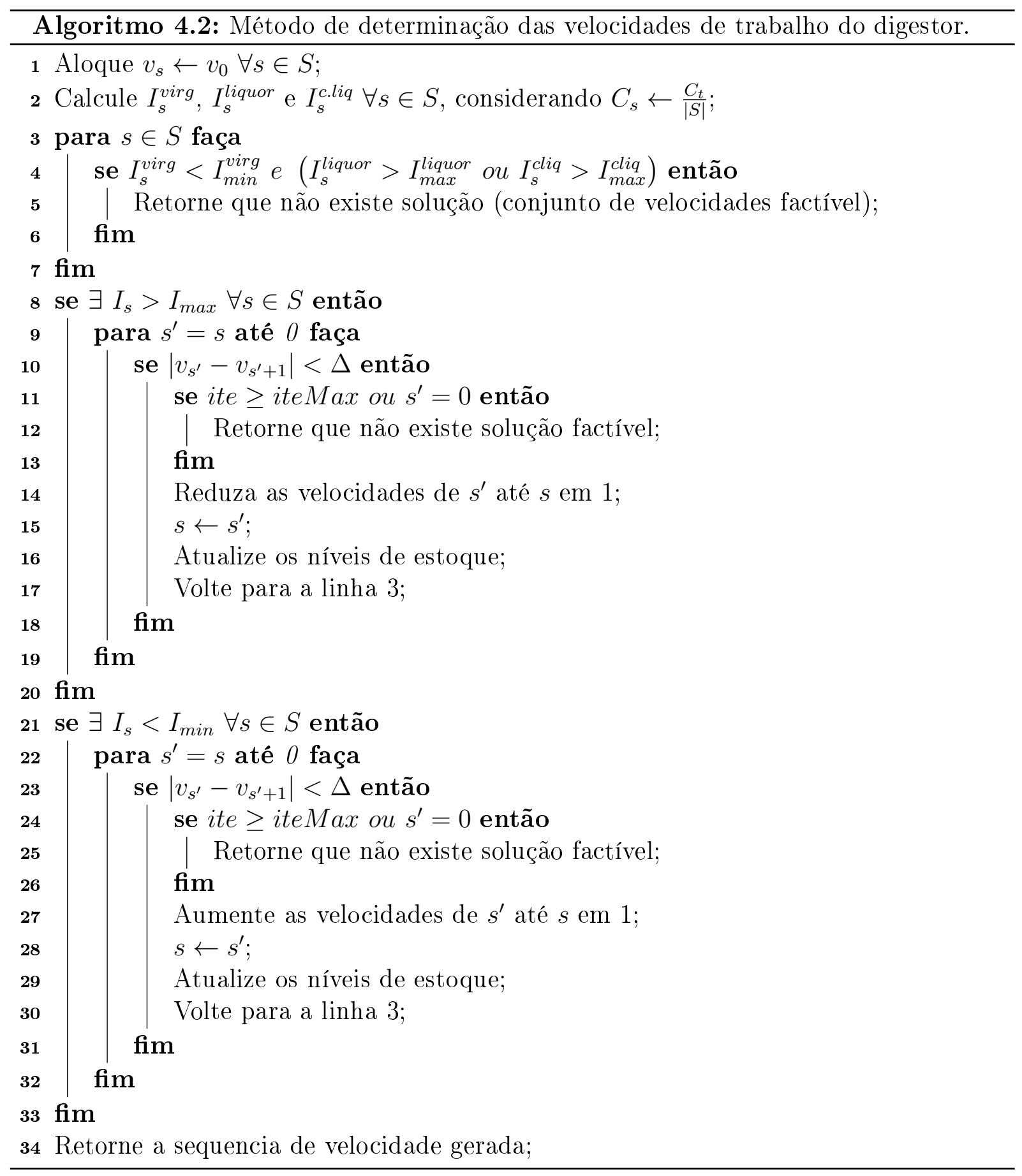

período. Estes cálculos são feitos com base nas restrições de balanceamento (3.55), (3.65) e (3.69), respectivamente. As linhas entre 3 e 7 são responsáveis por verificar se ocorre o caso de falta de celulose virgem associada a um excesso de licor negro fraco ou concentrado. Neste caso, não existe conjunto de velocidades capaz de gerar solução factível, pois para aumentar o nível de celulose virgem, é preciso aumentar a velocidade de trabalho, e para diminuir o nível de licor negro, é necessário reduzir esta mesma velocidade. As linhas entre 8 e 20 fazem a redução da velocidade do digestor quando o nível de algum 
dos três estoques $\left(I_{s}\right)$ for superior ao seu limite $\left(I_{\max }\right)$. Se um caso deste for encontrado, o procedimento retorna iterativamente até encontrar um micro-período no qual a redução de velocidade do digestor não viole o limite máximo de troca $(\Delta)$. Após a mudança de velocidade, o procedimento retorna para o micro-período que teve a velocidade alterada $\left(s^{\prime}\right)$, pois esta alteração pode ter gerado outras violações entre $s^{\prime}$ e $s$ que devem ser tratadas (Linha 15). Finalmente, os níveis de estoque são atualizados na Linha 16 e o método retorna para a Linha 3. O procedimento inverso (de aumento da velocidade do digestor) é feito entre as linhas 21 e 33 e tem o mesmo funcionamento apresentado para as linhas entre 8 e 20.

\subsubsection{Heurística gulosa de melhoria da sequência de produção}

Esta heurística visa reordenar as gramaturas que devem ser produzidas nos microperíodos de um mesmo período. O método tem o intuito de reduzir os custos de preparação de máquina, sem alterar custos de estoque e atraso. A troca dentro do período foi utilizada, pois os custos de estoque e atraso são computados apenas no final de cada período. Por exemplo, se cada período (dia) do horizonte de planejamento for dividido em três micro-períodos considerando apenas uma máquina, teremos que a heurística pode trocar as gramaturas entre os micro-períodos 1, 2 e 3, na primeira iteração. Na segunda iteração, pode trocar as gramaturas entre os micro-períodos 4, 5 e 6, e assim por diante, sempre considerando o menor custo de preparação de máquina com relação a gramatura já alocada. No caso de múltiplas máquinas de papel, a heurística considera os mesmos micro-períodos citados para todas as máquinas, podendo trocar gramaturas entre as máquinas de papel. O pseudo-código da heurística de melhoria é apresentado no Algoritmo 4.3 .

Entre as linhas 2 e 7 são feitas as remoções das gramaturas produzidas por todas as máquinas nos micro-períodos pertencentes ao período que está sendo alterado. Na Linha 5 estas gramaturas são adicionadas a um conjunto auxiliar $(\lambda)$ que será utilizado para reinserir estas na solução. Em seguida, as linhas entre 8 e 13 fazem a reinserção destas gramaturas a partir dos custos de preparação de máquina $(s l)$. A partir do conhecimento da última gramatura $j$ produzida em cada máquina de papel $m$, os itens do conjunto $\lambda$ são inseridos e removidos do conjunto iterativamente, até que o conjunto fique vazio. Este procedimento é feito para todos os períodos do horizonte de planejamento (Linha 1), iniciando a partir do primeiro período. 


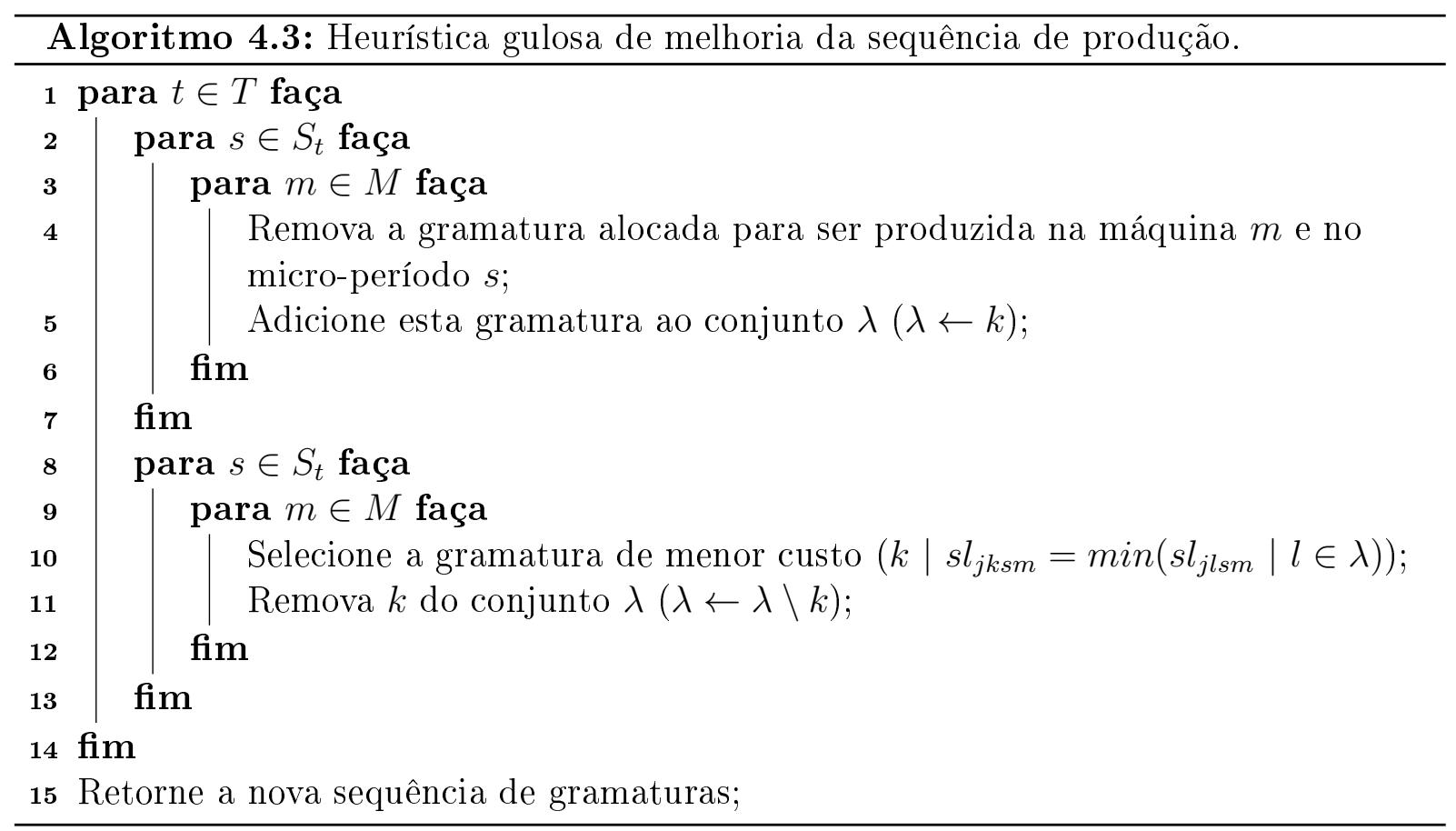

\subsection{Heurística construtiva baseada em arredondamento}

A heurística construtiva baseada em arredondamento visa definir o sequenciamento das máquinas de papel baseado nos resultados da relação linear das variáveis $X_{j s m}$. A partir destes valores, definem-se as probabilidades de escolha de cada gramatura a ser produzida em cada micro-período e em cada máquina de papel em relação a produção total do micro-período $\left(p_{j s m} \leftarrow \frac{X_{j s m}}{\sum_{k \in K} X_{k s m}}\right)$. Na relaxação linear do problema (3.45)(3.74), mais de um item pode ser produzido em cada micro-período devido a não garantia de integralidade das variáveis de decisão $Y_{j s m}$. Então $P_{j s m}$ visa indicar a relação entre os itens produzidos e sugerir qual item deve ser alocado em cada micro-período. Quanto maior a proporção da produção de um item $j$ com relação aos demais itens, maior será a probabilidade deste item ser escolhido no sequenciamento da produção. O Algoritmo 4.4 apresenta o pseudo-código desta heurística construtiva.

A Linha 1 faz referência a chamada do solver para a resolução da relaxação linear do modelo proposto ((3.45)-(3.74)). Entre as linhas 2 e 4 são calculadas as probabilidades de escolha de cada gramatura em cada micro-período e em cada máquina. As linhas entre 5 e 7 são responsáveis pela fixação da solução escolhida a partir das probabilidades $p_{j s m}$, onde $\bar{Y}_{j s m}$ designa esta solução de sequenciamento da produção nas máquinas.

Em alguns casos, o sub-problema resultante da fixação da sequência de produção das máquinas de papel pode ser infactível. Devido a proibição de tempo ocioso, em alguns 


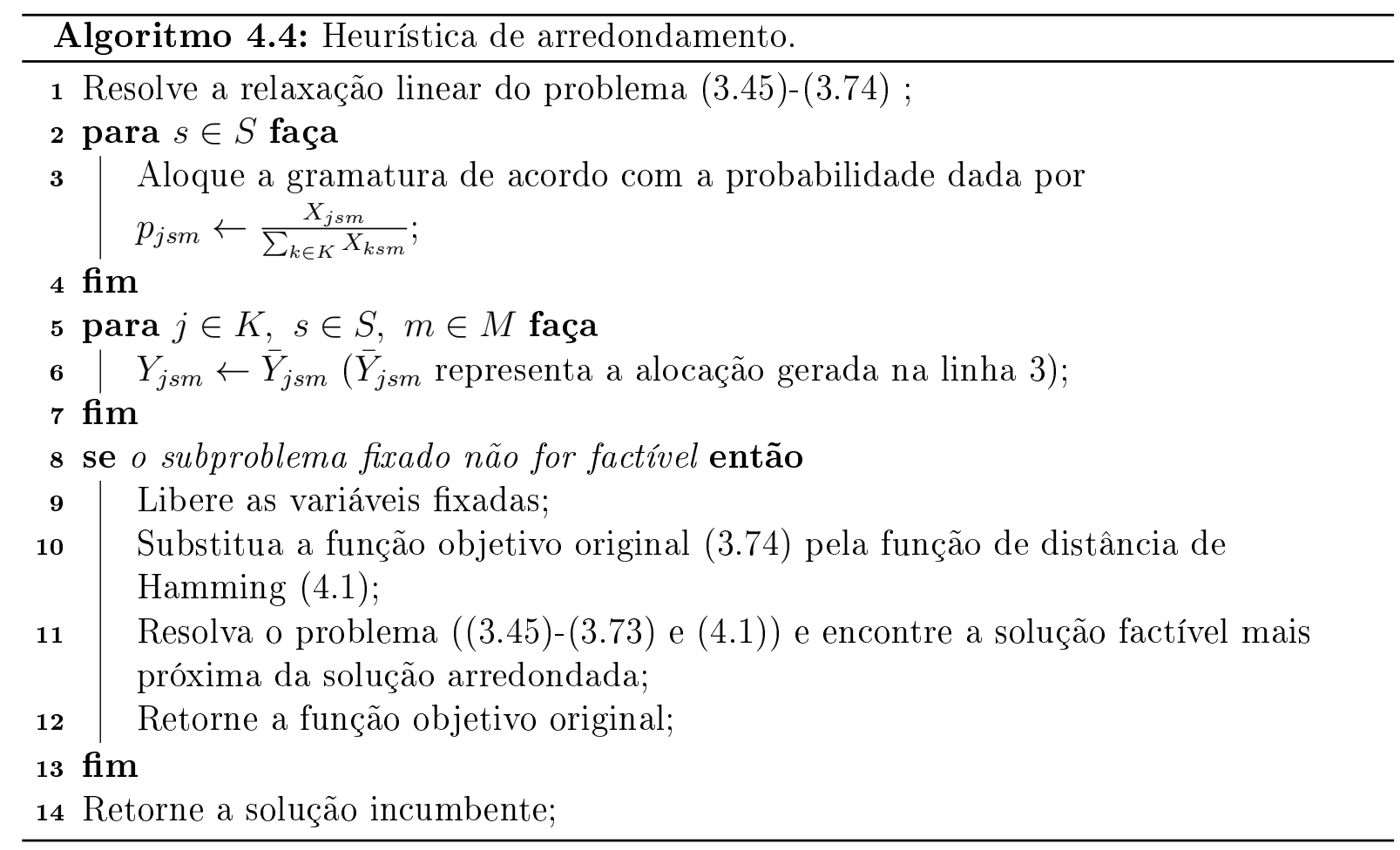

casos a fixação das sequências de produção das máquinas de papel pode gerar uma solução, na qual não exista sequência de velocidades do digestor capaz de atender a demanda por celulose virgem. Ou seja, não existe uma possível divisão de tempo de produção das gramaturas, na qual o digestor possa atender o consumo exigido, sem que ao menos um limites dos tanques de estocagem intermediário (celulose virgem, licor negro fraco ou licor negro concentrado) sejam desrespeitados. Neste caso, um processo de factibilização (linhas entre 8 e 13) é utilizado para encontrar a solução factível mais próxima. O processo de factibilização inicia pela liberação das variáveis $Y_{j s m}$ fixadas (Linha 9). A função objetivo original do problema é substituída por uma função de distância de Hamming (Hamming distance) das variáveis de preparação de máquina $Y_{j s m}$ com relação a alocação gerada $\bar{Y}_{j s m}$ (Linha 10). A distância de Hamming indica qual a distância entre duas soluções por meio da diferença absoluta entre cada um dos termos que compõem uma solução. No caso estudado, está distância é definida pela diferença no sequenciamento das máquinas de papel, verificando a quantidade de trocas de gramaturas necessárias para passar de uma solução à outra. A função objetivo substituta é definida da seguinte forma:

$$
f(x)=\sum_{\substack{j \in K \\ s \in S \\ m \in M}}\left|Y_{j s m}-\bar{Y}_{j s m}\right|
$$


O problema original ((3.45)-(3.73)) com função objetivo alterada (4.1) é resolvido por meio de um ferramenta comercial de otimização, até que a solução ótima seja encontrada ou o tempo limite seja atingido. Se houver solução factível, está é retornada como solução incumbente encontrada pela heurística construtiva. Caso contrário, a heurística retorna resultado infactível e o processo de solução termina.

\subsection{Heurística construtiva baseada em ciclos predefini- dos de produção}

Conforme mencionado, a heurística construtiva baseada em ciclos predefinidos de produção foi adaptada a partir da heurística de Figueira et al. (2013). A heurística construtiva de Figueira et al. (2013) se baseia nas ideias de ciclos de produção com tamanhos pré-definidos para gerar um plano de produção inicial utilizado na meta-heurística VNS (Variable Neighborhood Search). Segundo as definições de ciclo de Figueira et al. (2013), todo o atraso de atendimento da demanda no início de um ciclo deve ser produzido até o final deste mesmo ciclo. A partir desta suposição, são definidas as demandas que devem ser atendidas e alguns ciclos de produção. Os planos de produção para cada ciclo produtivo gerado são verificados de acordo com a função objetivo e o melhor resultado é retornado como a solução inicial gerada pela heurística construtiva.

O Algoritmo 4.5 apresenta um pseudo-código para a heurística construtiva baseada em ciclos predefinidos de produção. Para adaptar-se a heurística ao contexto do problema abordado, foram necessárias algumas considerações iniciais na definição de ciclo:

- Um ciclo produtivo não tem tamanho pré-definido

- Cada ciclo produtivo tem um processo de subida das gramaturas produzidas, seguido de outro de descida, ou vice-versa.

- Não existe a necessidade de atender a demanda atrasada até o final de cada ciclo

Para cada execução do método, são gerados $L$ ciclos de produção (Linha 1). A quantidade de ciclos varia de acordo com a quantidade de máquinas do problema. Em seguida, para cada ciclo de produção, o método tenta definir uma solução do problema (linhas entre 2 e 40). Da mesma forma que foi considerado na heurística construtiva, considerou-se neste método micro-períodos de tamanho fixo (Linha 6) e a demanda acumulada desde o início do horizonte de planejamento (Linha 7). Dentro do ciclo produtivo, se uma determinada gramatura tem demanda acumulada maior do que $\alpha \cdot \frac{C_{s}}{b_{j m}}$ (Linha 8), ou seja, 


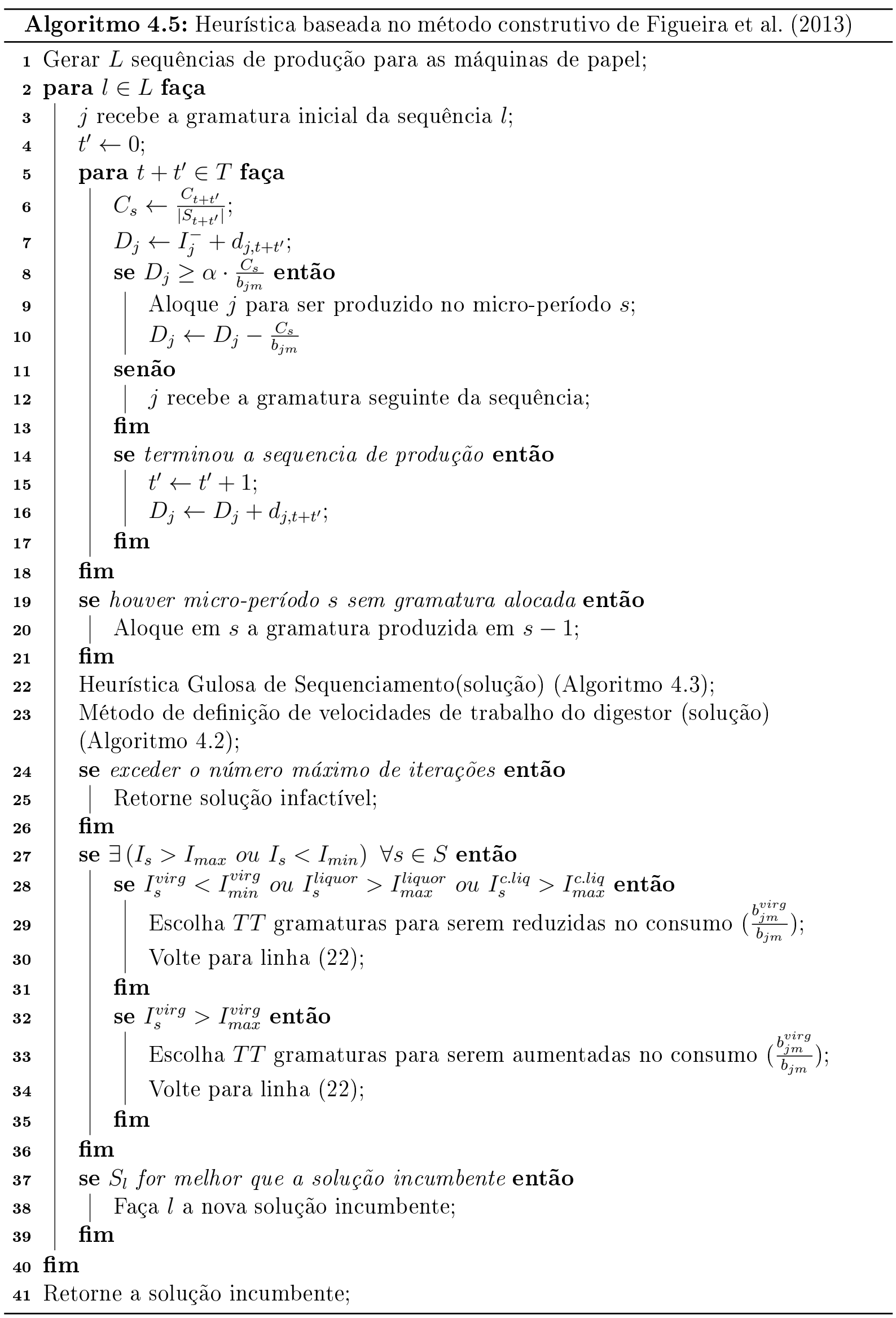


preenche pelo menos uma fração $\alpha$ do micro-período, ela deve ser alocada no micro-período $s$ (Linha 9). Caso contrário, passa-se a gramatura seguinte do ciclo produtivo (Linha 12). O parâmetro $\alpha$ e os dados $C_{s}$ e $b_{j m}$ têm o mesmo funcionamento utilizado na heurística construtiva gulosa (Seção 4.1). No momento em que um ciclo chega ao final, a demanda analisada para ser atendida é ampliada em um período (Linha 15) e o ciclo produtivo é reavaliado desde a primeira gramatura. Este procedimento visa adiantar a produção dos períodos futuros no próximo ciclo produtivo. Se não houver mais demanda a ser atendida, a última gramatura alocada é replicada até o final do horizonte de planejamento (linhas entre 19 e 21). As linhas entre 22 e 36 são similares ao procedimento feito na heurística construtiva gulosa. Entre as linhas 22 e 26 são executadas as heurísticas de melhoria do sequenciamento das máquinas de papel (Algoritmo 4.3) e a heurística de definição das velocidades do digestor (Algoritmo 4.2). Além disso, é feita a verificação da quantidade máxima de iterações do método. Na parte seguinte (linhas entre 27 e 36), é feito o processo de factibilização, apresentado em mais detalhes na Seção 4.1. Se a solução deste ciclo produtivo for melhor do que a solução incumbente, esta é salva (linhas entre 37 e 39). A Seção 4.3.1 apresenta o procedimento que descreve como foram gerados os ciclos de produção utilizados nesta heurística.

\subsubsection{Ciclos de produção utilizados}

A quantidade de ciclos distintos de produção obtidos difere de acordo com a quantidade de máquinas de papel do exemplar de teste abordado. A ideia é combinar ciclos de subida e descida nas máquinas para atender a demanda da melhor maneira possível. Para exemplares com uma única máquina de papel, são gerados dois ciclos produtivos passando por todas as gramaturas no processo. O primeiro ciclo é obtido por um processo de subida até o papel de maior gramatura, seguido de um processo de descida até o papel de menor gramatura, que por fim retorna ao papel de gramatura inicial (Figura 27a). O segundo ciclo de produção tem um processo inverso, isto é, começa pelo decréscimo da gramatura, seguido de um aumento posterior e retorno à gramatura inicial. A Figura 27 ilustra um exemplo dos dois primeiros tipos de ciclos de produção utilizados (Figura 27b).

Para os exemplares com duas máquinas, foram utilizadas as combinações destes dois ciclos de produção, além de uma divisão adicional. Como as máquinas de papel consideradas são homogêneas, a combinação dos dois tipos de ciclo gerou três combinações distintas, sendo elas: as duas máquinas usam o ciclo de produção 1, as duas máquinas usam o ciclo de produção do tipo 2 e cada máquina usa um dos dois ciclos de produção. A 


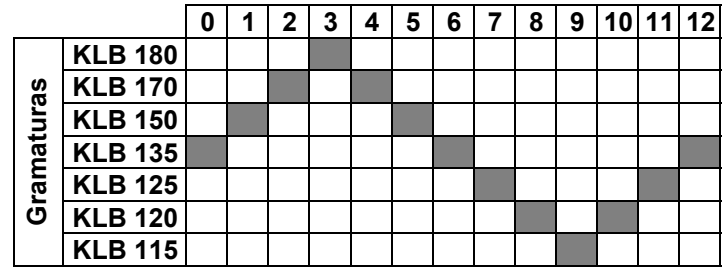

a) Ciclo 1

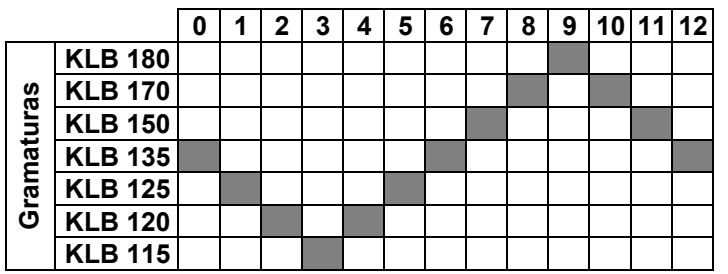

b) Ciclo 2

Figura 27: Ciclos de produção 1 e 2.

quarta combinação de ciclos de produção é apresentada na Figura 28. Como apresentado na Seção 3.4.1, pode ser feita uma divisão a priori das gramaturas por máquina de papel. Neste caso, os ciclos de produção vão depender da gramatura inicial da máquina de papel e das gramaturas aceitas pela máquina de papel na qual o ciclo será utilizado. No exemplo da Figura 28, temos uma máquina de papel, que pode produzir as gramaturas de 135 até $180 \mathrm{~g} / \mathrm{m}^{2}$, e a segunda máquina de papel, produzindo as gramaturas no intervalo de 115 até $135 \mathrm{~g} / \mathrm{m}^{2}$. A máquina de papel 1 inicia o ciclo na gramatura $150 \mathrm{~g} / \mathrm{m}^{2}$ (Figura 28a), enquanto a máquina de papel 2 tem $125 \mathrm{~g} / \mathrm{m}^{2}$ como gramatura inicial (Figura 28b).

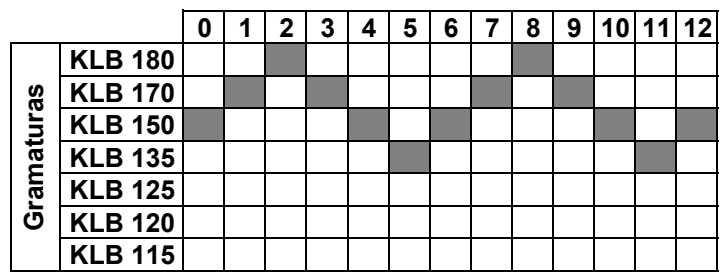

a) Máquina 1

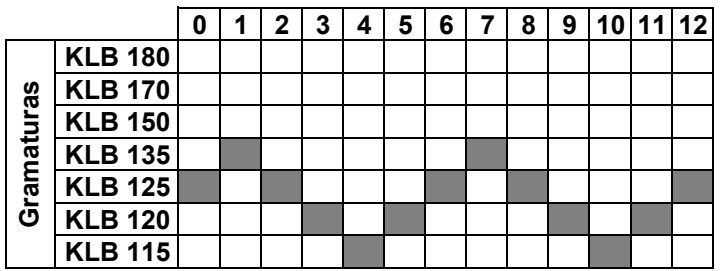

b) Máquina 2

Figura 28: Ciclos de produção com divisão das gramaturas por máquina de papel.

\subsection{Heurísticas do tipo relaxe-e-fixe}

Heurísticas do tipo relaxe-e-fixe (relax-and-fix) são heurísticas construtivas baseadas na modelagem matemática do problema (MIP-based heuristics). Estas heurísticas utilizam um conhecimento prévio do problema e explicam a forma como as variáveis inteiras se relacionam a fim de decompor o problema, para resolvê-lo iterativamente. O procedimento consiste em particionar o conjunto de variáveis inteiras do problema em sub-conjuntos disjuntos, que possam ser inicialmente relaxados e iterativamente integralizados, a fim de obter sub-problemas mais simples, que possam ser resolvidos de forma ótima ou quase ótima.

Em alguns casos, tanto variáveis inteiras como reais podem ser fixadas. No caso de problemas inteiros mistos (MIPs), o mais comumente verificado na literatura é o partici- 
onamento apenas das variáveis inteiras. As variáveis de decisão inteiras são as variáveis responsáveis pelo aumento da dificuldade do problema e, por este motivo, recebem maior atenção durante a resolução do problema. Segundo Pochet e Wolsey (2006), fixar apenas as variáveis binárias do problema fornece maior flexibilidade à heurística relaxe-e-fixe para os problemas de planejamento da produção, durante o processo de resolução, pois possibilita deslocamentos de produção durante as iterações, fixando apenas as decisões de quando produzir cada item, e deixando livre a decisão de quanto produzir.

Considere o conjunto de variáveis inteiras de um problema, denominado de $Q$. Considere ainda que este conjunto pode ser particionado em $R$ sub-conjuntos disjuntos, de tal forma que $Q^{r}$ representa o $r$-ésimo conjunto de variáveis com $r \in R$. Desta forma, temos que $Q=Q^{1} \cup \ldots \cup Q^{R}$ e $Q^{i} \cap Q^{j}=\emptyset \forall i, j \in R \mid i \neq j$. Considere ainda que possa haver a criação de partições de sobreposição $S U^{r} \forall r \in R$ (overlap), cujas variáveis também serão consideradas inteiras durante o processo de solução, mas não serão fixadas ao final de cada iteração. Ou seja, na $r$-ésima iteração do método serão consideradas inteiras as variáveis dos conjuntos $Q^{r}$ e $S U^{r}$, mas apenas os resultados das variáveis de $Q^{r}$ serão fixados.

Este tipo de heurística tem sido utilizada na resolução de problemas de planejamento da produção e tem obtido resultados muito promissores, como podem ser vistos na indústria de bebidas (BALDO et al., 2014; FERREIRA et al., 2010, 2009), indústria de ração animal (TOSO et al., 2009) e indústria de fundição (ARAUJO et al., 2008). Outros exemplos, em contextos mais gerais de planejamento da produção, podem ser encontrados em Mercé e Fontan (2003), Stadtler (2003) e Akartunali e Miller (2009).

O Algoritmo 4.6 apresenta um pseudo-código para a heurística relaxe-e-fixe considerando partições de sobreposição. A cada iteração, são consideradas inteiras $\left|Q^{r} \cup S U^{r}\right|$ variáveis (Linha 7) e são fixadas as variáveis contidas no conjunto $\left|Q^{r}\right|$ (Linha 8). Desta forma, pode-se definir um sub-problema $M I P^{r}$ na $r$-ésima iteração do método como sendo o problema (3.45)-(3.74) resultante da fixação das variáveis contidas no conjunto $Q^{1} \cup Q^{2} \cup \ldots \cup Q^{r-1}$ e da relaxação linear das variáveis contidas no conjunto $Q^{r+1} \cup$ $Q^{r+2} \cup \ldots \cup Q^{R} \backslash S U^{r}$. Apesar do aumento de complexidade adicionado pela consideração das partições de sobreposição, em alguns casos, seu uso pode ser vantajoso. A vantagem consiste em considerar um detalhamento maior em parte (ou no todo) das variáveis que serão fixadas na iteração seguinte. Considerando estas variáveis inteiras, teremos menos chances de gerar problemas infactíveis nas iterações imediatamente posteriores, dado que o espaço de solução do sub-problema estará mais próximo ao problema original. No contexto de planejamento da produção, as partições de sobreposição são mais frequentemente 
utilizadas associadas ao particionamento por períodos, no qual são considerados períodos futuros de sobreposição, a fim de adiantar a produção de forma mais adequada. Exemplos de trabalhos com esta estratégia aparecem em: Stadtler (2003) e Mercé e Fontan (2003). Para mais detalhes acerca do método relaxe-e-fixe, ver, por exemplo, Pochet e Wolsey (2006).

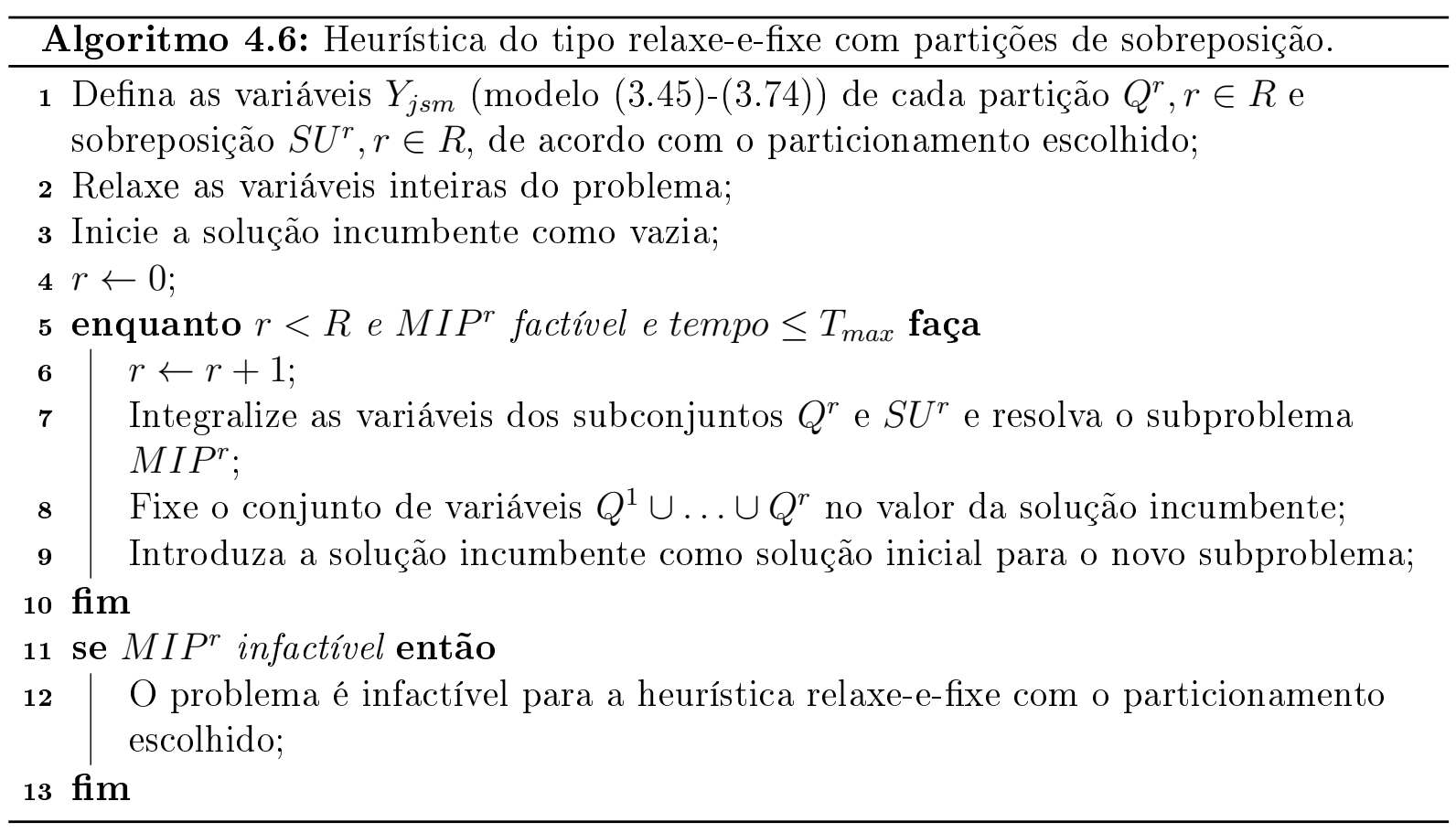

Além da definição do método, precisa-se definir quais variáveis serão particionadas e a forma como o particionamento destas variáveis será feito (Linha 1). No problema abordado, existem dois grupos de variáveis inteiras a serem particionadas. O primeiro grupo é responsável pelo sequenciamento da velocidade de trabalho do digestor, sendo formado pelas variáveis $Y_{v s}^{\text {dig }}$, no qual $v$ indica a velocidade alocada no micro-período $s$, caso $Y_{v s}^{d i g}=1$. O segundo grupo é formado pelas variáveis de sequenciamento da produção das máquinas de papel, anteriormente denominada $Y_{j s m}$, que define se a gramatura $j$ será produzida no micro-período $s$ na máquina de papel $m\left(Y_{j s m}=1\right)$, ou não $\left(Y_{j s m}=0\right)$. As variáveis de troca da preparação $\left(Z_{j k s m}\right)$ podem ser definidas de acordo com as variáveis $Y_{j s m}$ correspondentes e durante a resolução das partições, elas podem ser relaxadas, pois a integralidade das variáveis $Y_{j s m}$ fazem com que apenas valores inteiros sejam possíveis para as variáveis $Z_{k j s m}$ (restrições (3.63) e (3.64)). O método ainda é composto por alguns passos iniciais de relaxação das variáveis inteiras do problema original (Linha 2). Estas variáveis são posteriormente integralizadas de acordo com o particionamento utilizado (linhas entre 5 e 10).

Como a heurística relaxe-e-fixe se baseia em relaxação linear e fixação das variáveis 
do problema, não existe garantia de factibilidade da solução final da heurística. No caso do problema estudado, esta infactibilidade pode ocorrer devido a falta ou mesmo excesso de celulose virgem, por exemplo. A partir do momento que o método não é capaz de encontrar uma solução factível para uma partição $r$, o procedimento é encerrado por não ser mais capaz de fazer a fixação das variáveis do conjunto $Q^{r}$ (linhas entre 11 e 13).

As partições aplicadas sobre as variáveis de decisão do digestor são apresentadas na Seção 4.4.1 e as partições utilizadas nas variáveis de sequenciamento das máquinas de papel são apresentadas na Seção 4.4.2. As combinações verificadas entre as partições de ambos grupos de variáveis de decisão são apresentadas na Seção 4.4.3, o que geram as variantes da heurística relaxe-e-fixe testadas neste trabalho.

\subsubsection{Particionamentos das variáveis de decisão do digestor}

Para o particionamento das variáveis de decisão do digestor foram implementadas cinco estratégias, sendo duas por micro-períodos, duas por velocidades e uma integralizando todas as variáveis após a definição de um plano de produção para as máquinas de papel estar completamente definido. Para as partições por micro-períodos, são considerados dois parâmetros $T S$ e $T F$. O parâmetro $T F$ descreve o número de micro-períodos que serão fixados a cada iteração, ou seja, o conjunto $Q^{r}$. Já o parâmetro $T S$ representa o tamanho das partições de sobreposição, ou seja, $S U^{r}$. O mesmo conceito vale para as partições por velocidade, sendo que $T S$ e $T F$ se referem a quantidade de velocidades consideradas em cada partição. Apresentamos abaixo cada particionamento em mais detalhes, com o auxílio de algumas ilustrações.

\section{Particionamento por micro-períodos progressivo no tempo}

A partição por micro-períodos progressivo no tempo (forward) é uma das mais utilizadas na literatura, principalmente em problemas de planejamento da produção. A existência do horizonte de planejamento torna intuitiva a resolução do problema de forma iterativa, do início para o final do horizonte de planejamento. Desta forma, a cada iteração resolve-se um subproblema que considera inteiras as variáveis de decisão de todas as velocidades para $T F+T S$ micro-períodos. Destas, as primeiras $T F$ são fixadas no valor da solução incumbente e novas variáveis são integralizadas. A Figura 29 apresenta um exemplo deste particionamento com $T F=2$ e $T S=1$.

2. Particionamento por micro-períodos regressiva no tempo 


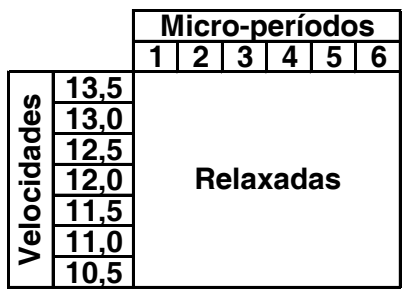

a) Relaxação inicial

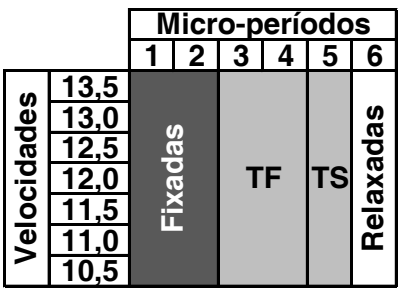

d) Passo 3 (integralização)

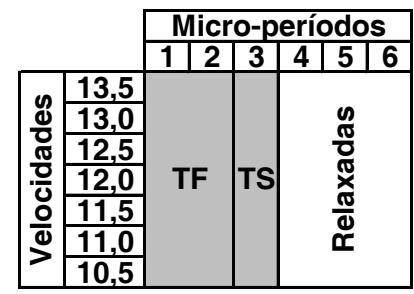

b) Passo 1 (integralização)

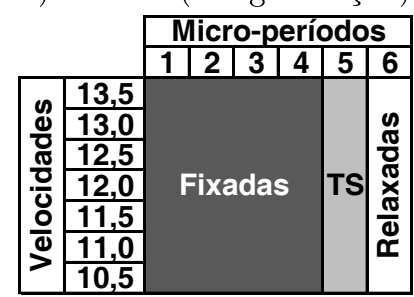

e) Passo 4 (fixação)

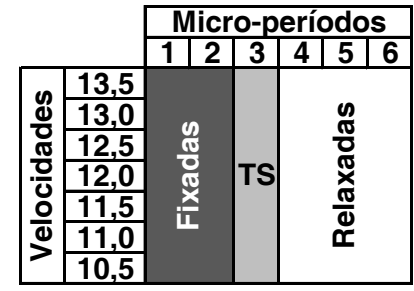

c) Passo 2 (fixação)

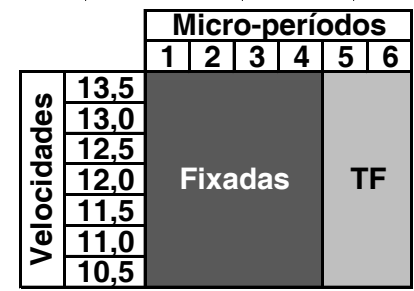

f) Passo 5 (integralização)

Figura 29: Ilustração do particionamento 1 para as variáveis de decisão do digestor.

Este particionamento tem concepção parecida com o anterior, diferenciando-se na sequência em que os períodos são integralizados. Neste caso, as partições são geradas a fim de integralizar e fixar as variáveis de decisão do final para o início do horizonte de planejamento. A ideia é evitar infactibilidades nas partições finais em exemplares nos quais a capacidade produtiva se torna apertada e a produção acaba sendo postergada pelas primeiras iterações do método. A Figura 30 apresenta uma ilustração do método considerando $T F=2$ e $T S=1$. Como pode ser verificado, o segundo particionamento é simétrico ao primeiro particionamento em cada passo do método, em relação ao horizonte de planejamento.

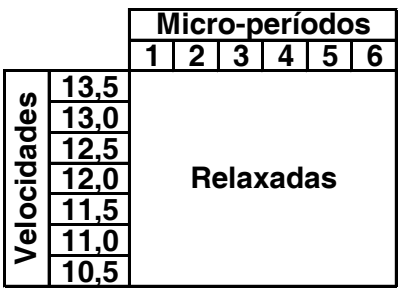

a) Relaxação inicial

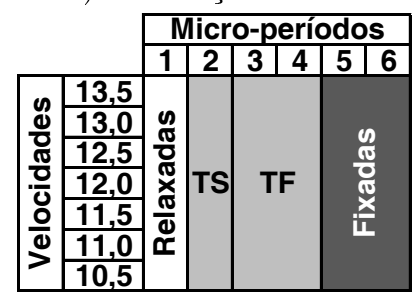

d) Passo 3

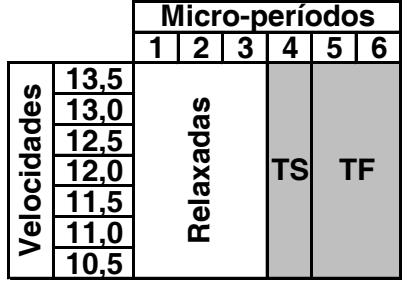

b) Passo 1

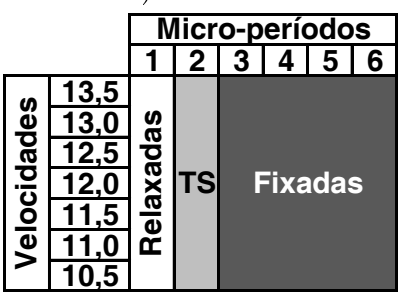

e) Passo 4

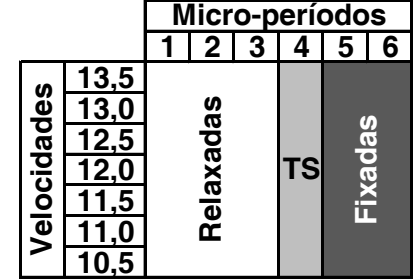

c) Passo 2

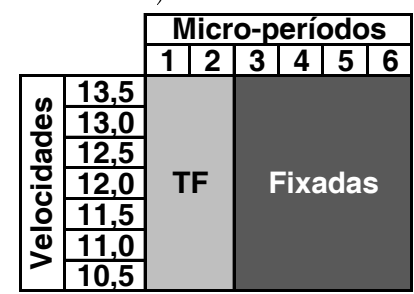

f) Passo 5

Figura 30: Ilustração do particionamento 2 para as variáveis de decisão do digestor.

3. Particionamento por velocidade das extremidades para o centro

Como as trocas de velocidade do digestor são controladas para evitar mudanças 
bruscas, fez-se necessário elaborar formas de integralizar e fixar as variáveis de decisão que evitem gerar infactibilidades entre partições consecutivas, ou que tornem os sub-problemas seguintes muito restritos. A primeira partição por velocidade consiste em fixar as variáveis da extremidade para o centro. Desta forma, as velocidades mais extremas serão escolhidas apenas quando necessárias e iterativamente reduzimos o espaço de busca. A Figura 31 ilustra este particionamento com $T F=1 \mathrm{e}$ $T S=1$. Diferentemente do que foi feito nos particionamentos por micro-período, aqui são integralizados $T F+T S$ velocidades nas duas extremidades, ou seja, cada sub-problema resolvido terá $2 \cdot(T F+T S)$ velocidades consideradas inteiras, das quais $2 \cdot T F$ serão fixadas.

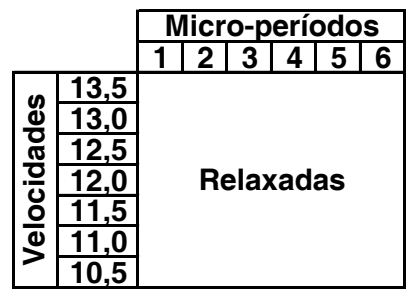

a) Relaxação inicial

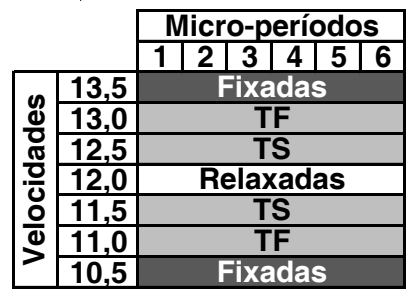

d) Passo 3

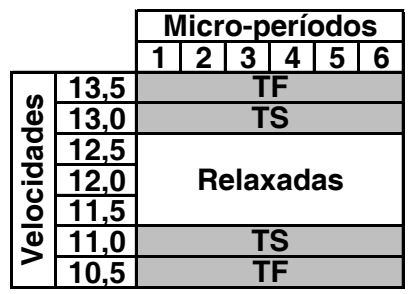

b) Passo 1

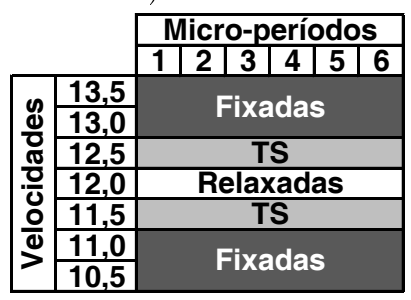

e) Passo 4

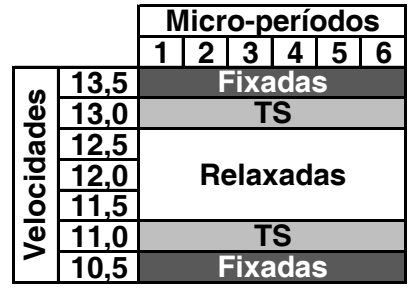

c) Passo 2

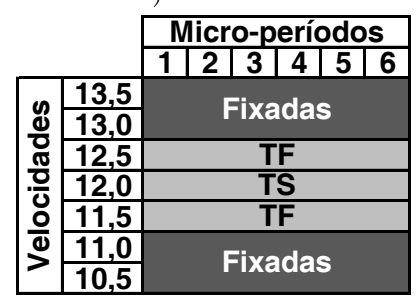

f) Passo 5

Figura 31: Ilustração do particionamento 3 para as variáveis de decisão do digestor.

4. Particionamento por velocidades da velocidade inicial $\left(Y_{v 0}^{d i g}\right)$ para as extremidades Foi considerado ainda o movimento contrário ao do particionamento anterior. Neste caso, ao invés de considerarmos a velocidade central como a inicial e partir em direção para as extremidades, consideramos como velocidade de partida a velocidade inicial de trabalho do digestor, indicada pelo dado de entrada $\left(Y_{v 0}^{\text {dig }}\right)$. Neste caso, a quantidade de velocidades integralizadas na primeira iteração será de $T F+2 \cdot T S$, das quais $T F$ serão fixadas. Para as demais iterações, vale a mesma regra do caso anterior, ou seja, $2 \cdot(T F+T S)$ velocidades consideradas inteiras com a posterior fixação de $2 \cdot T F$. A Figura 32 apresenta um exemplo deste particionamento com $T F=1, T S=1$ e $Y_{v 0}^{\text {dig }}=12,0$.

5. Partição baseada em decomposição usando relaxação linear

Neste particionamento, todas as variáveis de decisão do digestor são agrupadas em 


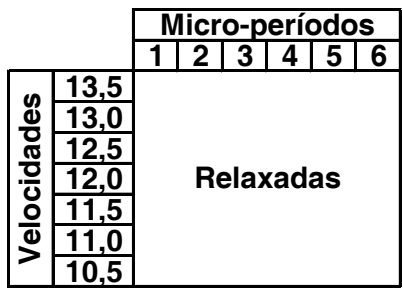

a) Relaxação inicial

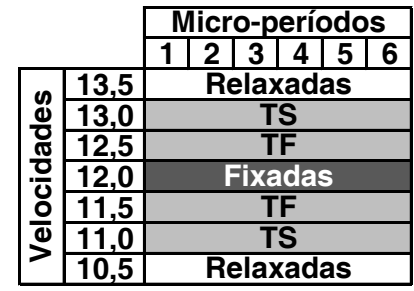

d) Passo 3

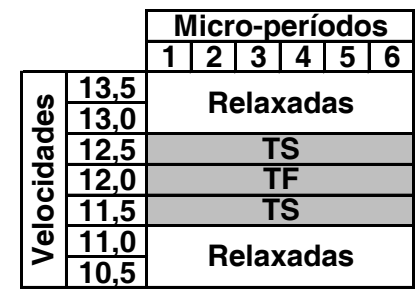

b) Passo 1

\begin{tabular}{|c|c|c|}
\hline & Micro-períodos \\
\hline & & \begin{tabular}{l|l|l|l|l|l}
1 & 2 & 3 & 4 & 5 & 6 \\
\end{tabular} \\
\hline \multirow{7}{*}{$\begin{array}{l}\frac{y}{2} \\
\frac{8}{0} \\
\frac{\pi}{0} \\
\frac{0}{0} \\
\frac{0}{0} \\
\end{array}$} & 13,5 & Relaxadas \\
\hline & 13,0 & TS \\
\hline & 12,5 & \\
\hline & 12,0 & Fixadas \\
\hline & 11,5 & \\
\hline & 11,0 & TS \\
\hline & 10,5 & Relaxadas \\
\hline
\end{tabular}

e) Passo 4

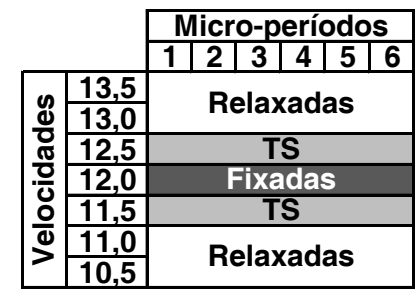

c) Passo 2

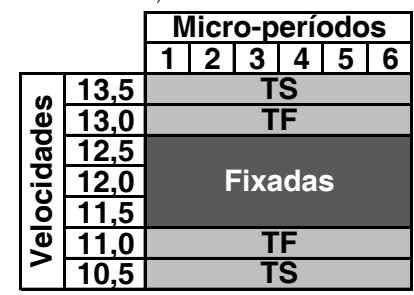

f) Passo 5

Figura 32: Ilustração do particionamento 4 para as variáveis de decisão do digestor.

uma única partição. A partição criada somente é aplicada (integralizada) após a fixação das decisões de produção das máquinas de papel. Esta partição foi proposta como uma forma de "decomposição" do problema por meio da relaxação linear do modelo (3.45)-(3.74). Neste caso, consideramos todas as variáveis relaxadas do digestor e aplicamos as partições sobre as variáveis de sequenciamento das máquinas de papel. Após aplicar a última partição sobre as variáveis das máquinas de papel, integralizamos todas as variáveis de controle da velocidade do digestor e resolvemos este último sub-problema.

\subsubsection{Particionamentos das variáveis de decisão das máquinas de papel}

1. Particionamento por micro-períodos progressiva no tempo

O particionamento por micro-períodos progressiva no tempo tem funcionamento similar a partição progressiva no tempo para as variáveis de velocidade do digestor, diferindo apenas na forma como trata-se a ocorrência de múltiplas máquinas de papel. A Figura 33 apresenta uma ilustração deste particionamento para duas máquinas de papel, $T F=2$ e $T S=1$. A cada iteração, são definidas os micro-períodos que serão integralizados e fixados para todas as máquinas de papel. Na ilustração podemos verificar que as variáveis da primeira e da segunda máquina de papel são tratadas da mesma maneira, sendo integralizadas e fixadas simultaneamente.

2. Particionamento por micro-períodos e máquinas de papel progressiva no tempo O particionamento combinado de micro-períodos e máquinas de papel considera 


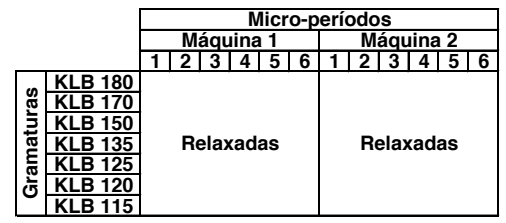

a) Relaxação inicial

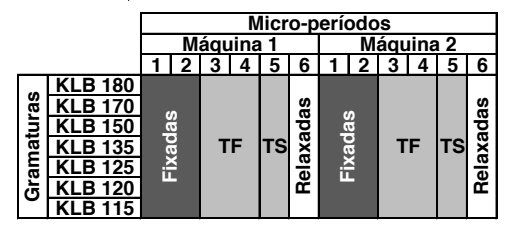

d) Passo 3 (integralização)

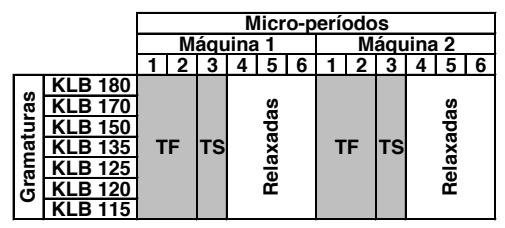

b) Passo 1 (integralização)

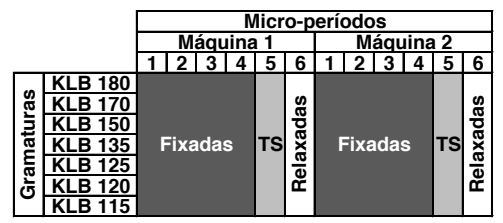

e) Passo 4 (fixação)

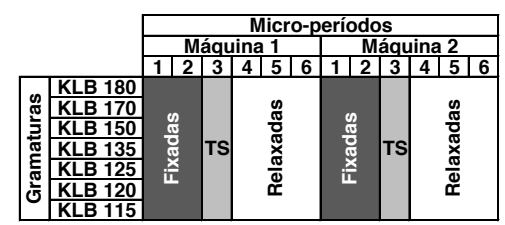

c) Passo 2 (fixação)

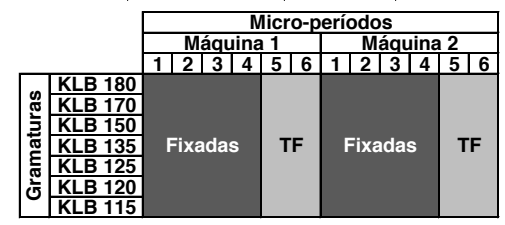

f) Passo 5 (integralização)

Figura 33: Ilustração do particionamento 1 para as variáveis de decisão da máquina de papel.

primeiramente o horizonte de planejamento de cada máquina de papel. A Figura 34 facilita o entendimento, dado que visualmente podemos considerar que o início do horizonte de planejamento de uma máquina de papel $m$ pode ser ligado com o final do horizonte de planejamento da máquina de papel anterior $(m-1)$. Na Figura 34, por exemplo, o micro-período 1 da máquina 2 se comporta como se fosse o micro-período imediatamente subsequente ao micro-período 6 da máquina 1 . Desta forma, o horizonte de planejamento combinado teria tamanho $S \cdot M$, no qual $S$ indica o número de micro-períodos do horizonte de planejamento e $M$ a quantidade de máquinas de papel. O particionamento é feito de forma progressiva no tempo, de acordo com os tamanhos de $T F$ e $T S$ e a sequência de $S \cdot M$ micro-períodos. Na ilustração da Figura 34 utilizou-se $T F=4$ e $T S=1$.

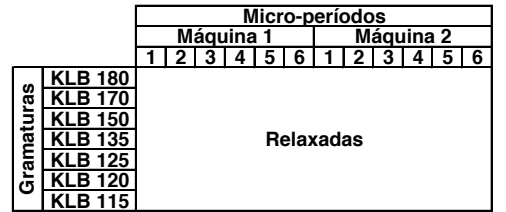

a) Relaxação inicial

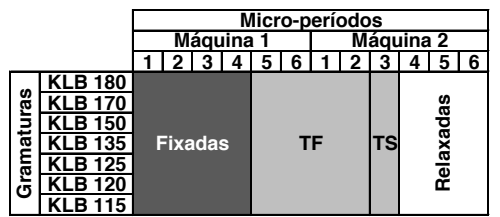

d) Passo 3

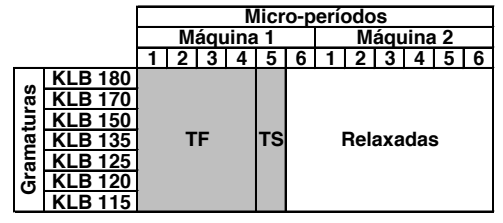

b) Passo 1

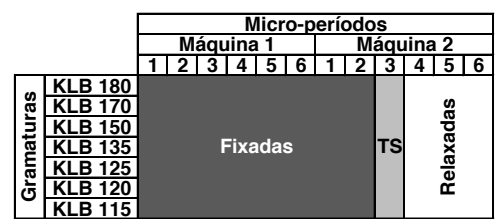

e) Passo 4

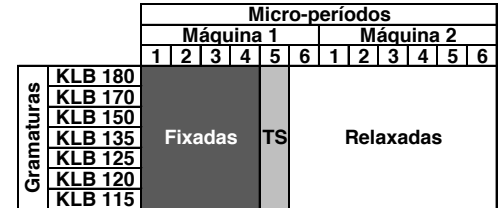

c) Passo 2

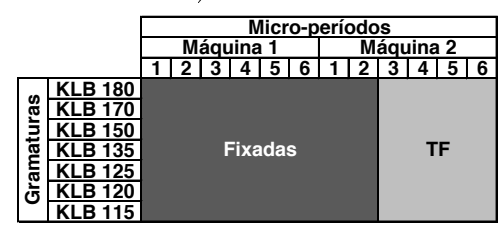

f) Passo 5

Figura 34: Ilustração do particionamento 2 para as variáveis de decisão da máquina de papel.

\section{Particionamento por micro-períodos regressivo no tempo}

Este particionamento é similar ao primeiro particionamento das variáveis de deci- 
são das máquinas de papel, com exceção da direção que percorre. A relação entre estes dois tipos de particionamento é similar à ocorrida com os dois primeiros particionamentos para as variáveis do digestor. A Figura 35 apresenta uma ilustração com $T F=2$ e $T S=1$ e as partições são geradas simultaneamente para todas as máquinas do final para o início do horizonte de planejamento.

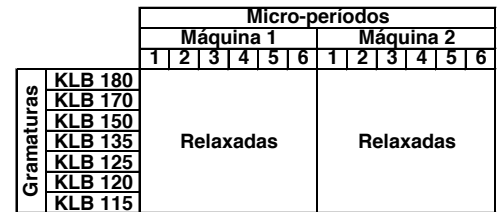

a) Relaxação inicial

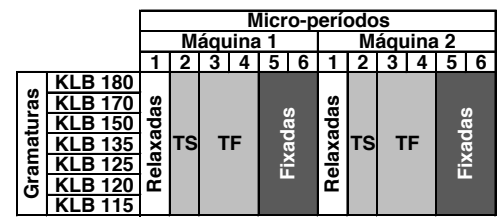

d) Passo 3

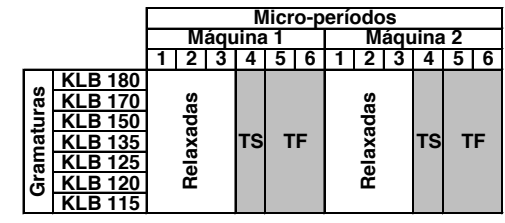

b) Passo 1

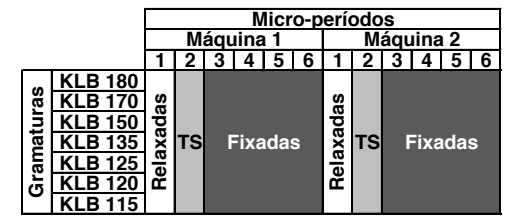

e) Passo 4

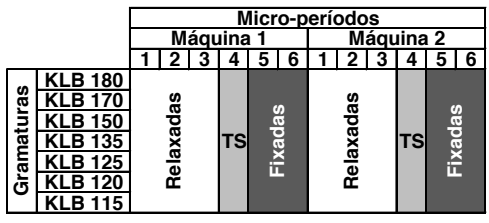

c) Passo 2

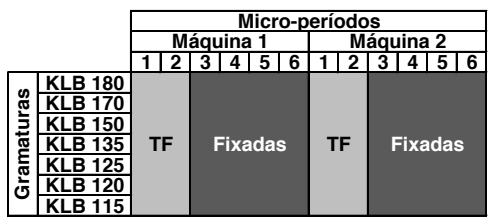

f) Passo 5

Figura 35: Ilustração do particionamento 3 das variáveis de decisão da máquina de papel.

4. Particionamento por micro-períodos e máquinas de papel regressivo no tempo

Este particionamento é simétrico ao apresentado na partição por micro-períodos e máquinas de papel progressivo no tempo. Pode-se considerar um horizonte de planejamento com tamanho $S \cdot M$, onde integralização e fixação são feitas do final para o início deste "horizonte", como é ilustrado no exemplo da Figura 36 com $T F=4$ e $T S=1$, porém agora iniciando com a última máquina de papel.

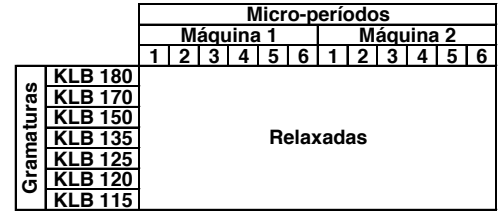

a) Relaxação inicial

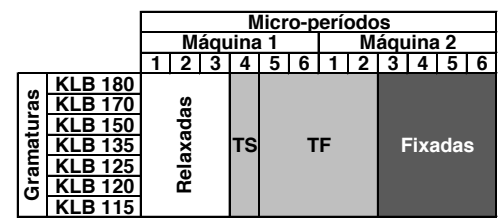

d) Passo 3

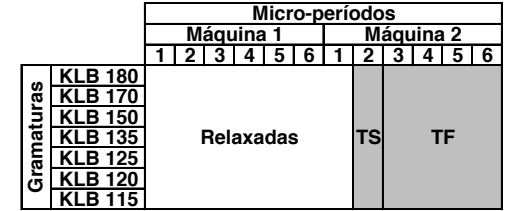

b) Passo 1

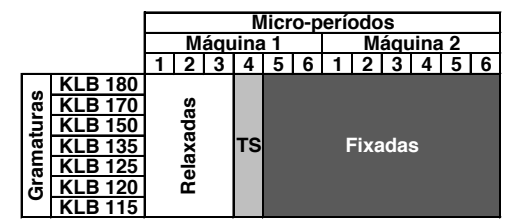

e) Passo 4

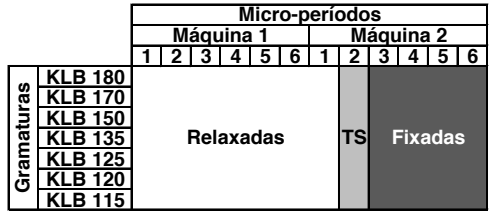

c) Passo 2

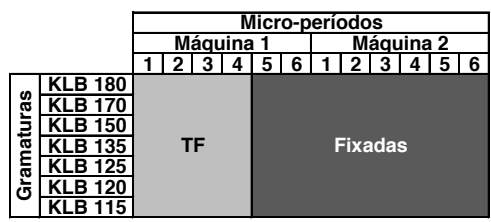

f) Passo 5

Figura 36: Ilustração do particionamento 4 para as variáveis de decisão da máquina de papel. 
O particionamento por produto tem como intuito integralizar as variáveis de uma ou mais gramaturas de forma simultânea para todo o horizonte de planejamento. Desta forma, iterativamente definimos o plano de produção de cada item. Neste particionamento em questão, optamos por iniciar pelas gramaturas mais leves e ir aumentando de acordo com o crescimento de gramatura. Da mesma maneira dos particionamentos anteriores, os parâmetros $T F$ e $T S$ são responsáveis pelo controle da quantidade de gramaturas que serão fixadas e integralizadas, respectivamente.

A Figura 37 ilustra este tipo de particionamento com $T F=2$ e $T S=1$.

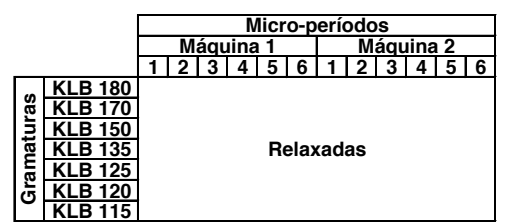

a) Relaxação inicial

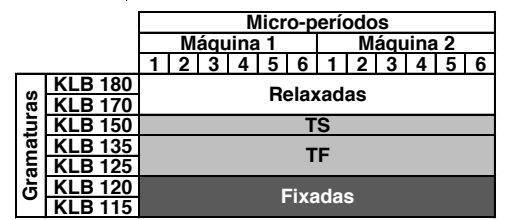

d) Passo 3

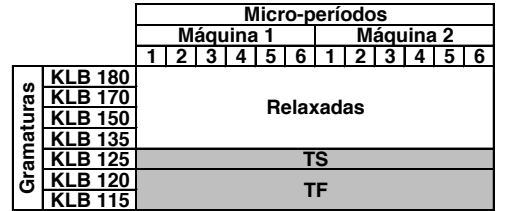

b) Passo 1

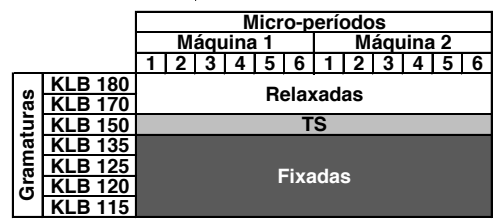

e) Passo 4

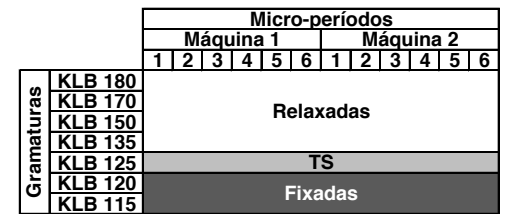

c) Passo 2

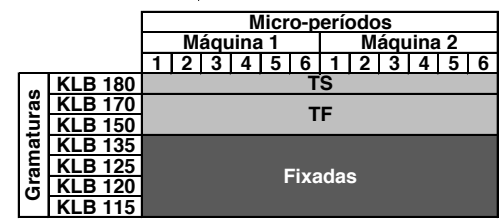

f) Passo 5

Figura 37: Ilustração do particionamento 5 para as variáveis de decisão da máquina de papel.

\section{Particionamento por produtos e máquinas de papel}

No particionamento por produtos e máquinas de papel são geradas partições diferentes para escolha de um mesmo item em máquinas de papel distintas. Iniciando pela primeira máquina, alocam-se todas gramaturas de acordo com TS e TF até que a última gramatura seja alocada e, somente então se inicia a máquina seguinte. Assim, definimos o plano de produção completo (ou quase completo, pois são fixadas apenas as variáveis de troca e preparação de máquina) para uma máquina de papel antes de iniciar a solução inteira da seguinte. Caso sobrem espaços na última partição de uma máquina de papel $m$, estes podem ser preenchidos com as primeiras gramaturas da máquina $m+1$. A Figura 38 ilustra este particionamento para $T F=3$ e $T S=2$ e o caso onde ocorre a sobra de espaço em partições (Figuras 38d e 38f). Na situação da Figura 38d, como $T S=2$, a partição avança em um produto na máquina 2. Este processo contínua até o passo 6 (Figura 38g) em que todas as variáveis de decisão da máquina 1 são fixadas, restando variáveis de preparação de máquina livres apenas na máquina 2.

7. Particionamento por produtos ordenados por preço (do maior para o menor) 


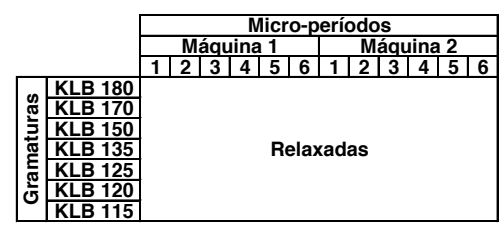

a) Relaxação inicial

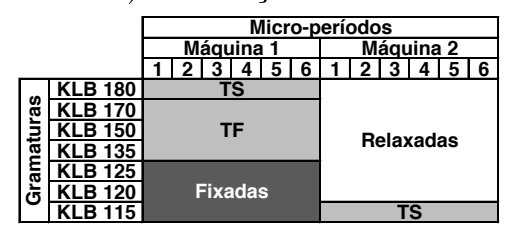

d) Passo 3

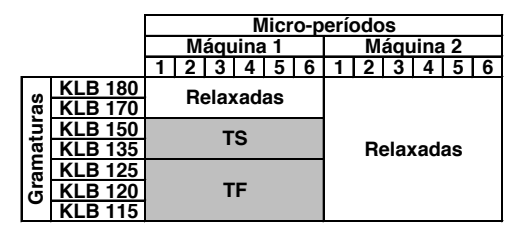

b) Passo 1

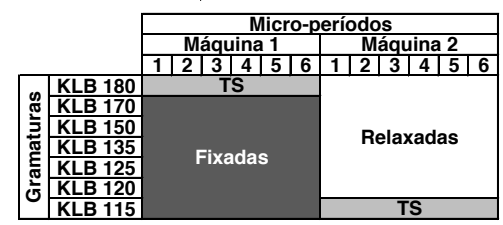

e) Passo 4

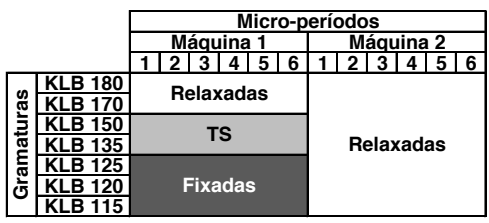

c) Passo 2

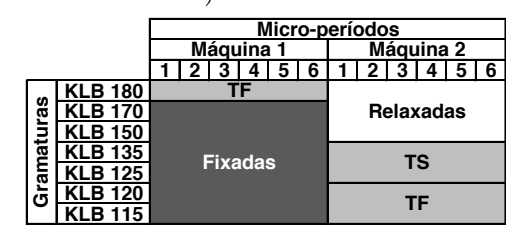

f) Passo 5

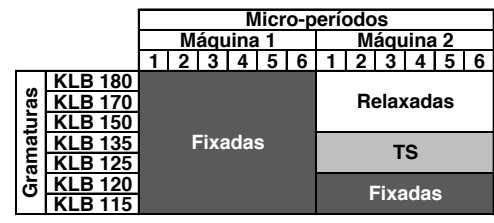

g) Passo 6

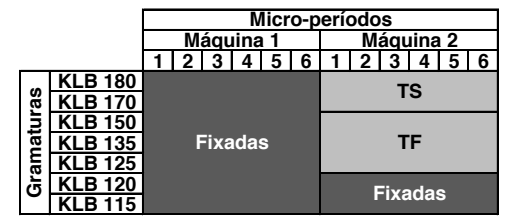

h) Passo 7

Figura 38: Ilustração do particionamento 6 para as variáveis de decisão da máquina de papel.

O particionamento por produtos ordenados por preço foi desenvolvido com o intuito de verificar a influência dos custos (de estoque, de atraso e de preparação de máquina) sobre a qualidade da solução final. Como os custos de preparação de máquinas, os custos de estoque e os custos de atraso são todos baseados nos preços de cada gramatura (ver Seção 3.5.1). Desta forma, pode ser vantajoso fixar primeiramente as variáveis referentes aos produtos de maior valor, que serão produzidos de forma mais ideal. A Figura 39 apresenta uma ilustração deste particionamento com $T F=1$ e $T S=2$. Nesta figura, os preços associados a cada gramatura por tonelada são apresentados ao lado de seus nomes. As gramaturas são alocadas iniciando pelos tipos de maior custo e seguindo de forma decrescente.

8. Particionamento por produto ordenados por preço e por máquinas de papel O particionamento por produtos ordenados por preço e máquinas de papel é similar ao particionamento por produtos e máquinas, diferenciando-se apenas na questão da ordenação dos itens pelo preço. O plano de produção de cada máquina de papel é gerado iterativamente. Com isto, obtemos partições menores que o particionamento apenas por produtos ordenados, o que possibilita verificar a influência deste planejamento integrado entre máquinas de papel. A Figura 40 ilustra este tipo de particionamento. Neste exemplo foram utilizadas partição com três produtos $(T F=3)$ e sobreposição de mais dois produtos $(T S=2)$. 


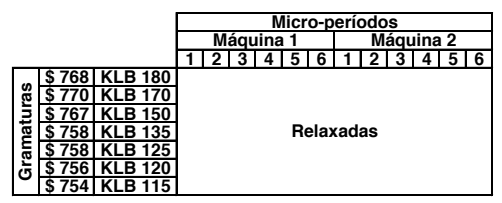

a) Relaxação inicial

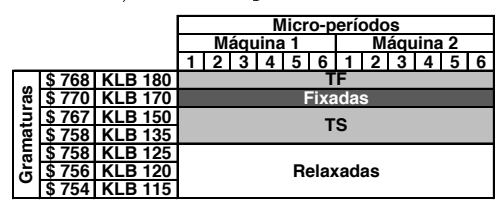

d) Passo 3

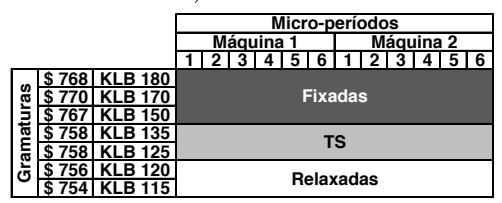

f) Passo 6

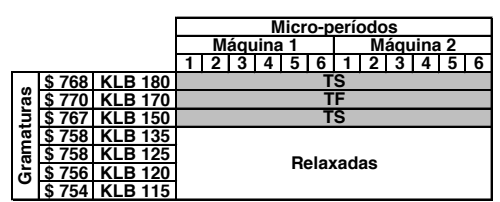

b) Passo 1

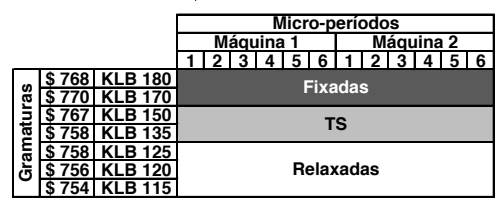

e) Passo 4

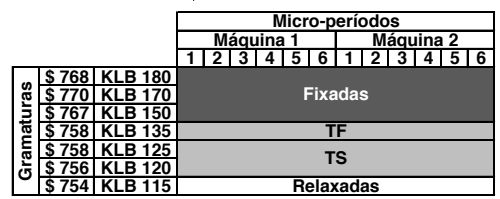

f) Passo 7

\begin{tabular}{|c|c|c|}
\hline Micro-periodos \\
\hline Máquina 1 Máquina 2
\end{tabular}

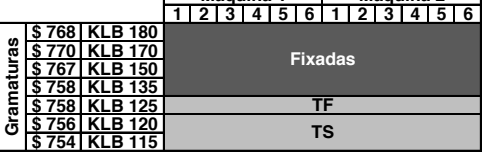

f) Passo 9

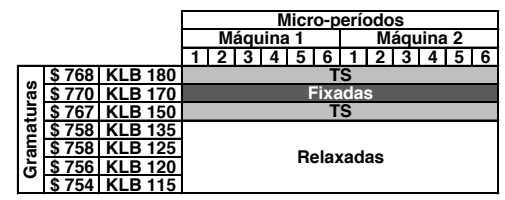

c) Passo 2

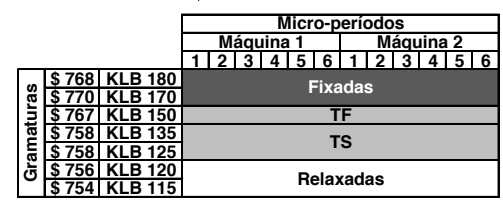

f) Passo 5

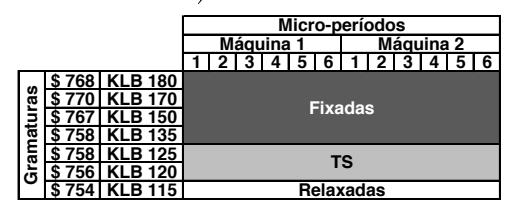

f) Passo 8

Figura 39: Ilustração do particionamento 7 para as variáveis de decisão da máquina de papel.

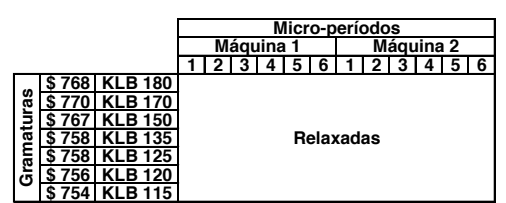

a) Relaxação inicial

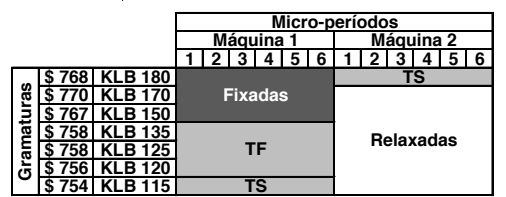

d) Passo 3

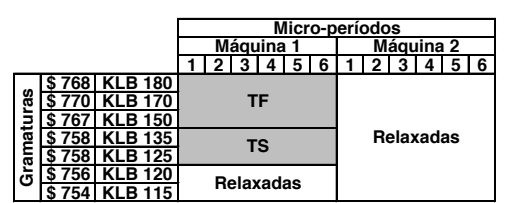

b) Passo 1

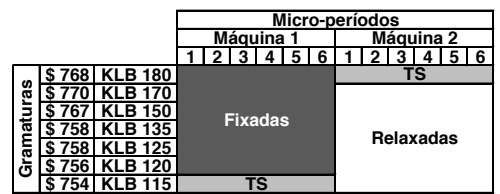

e) Passo 4

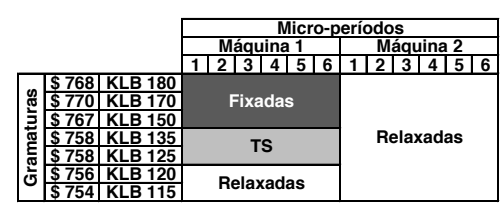

c) Passo 2

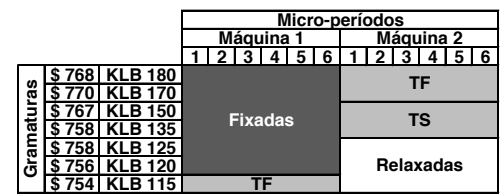

f) Passo 5

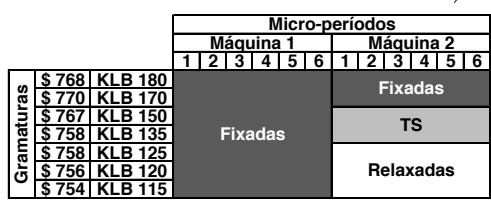

f) Passo 6

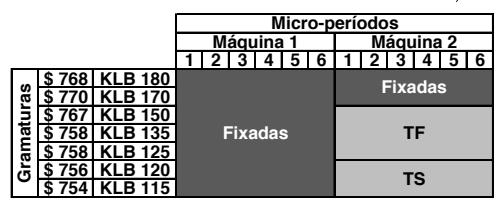

f) Passo 7

Figura 40: Ilustração do particionamento 8 para as variáveis de decisão da máquina de papel.

\subsubsection{Combinações desenvolvidas}

Para que o método relaxe-e-fixe possa ser aplicado ao problema estudado, é necessário definir um particionamento para as variáveis de controle da velocidade do digestor e 
outro particionamento para as variáveis de sequenciamento das máquinas de papel. Esta combinação deve ser condicionada à forma de funcionamento de ambos os particionamentos para trabalharem em conjunto harmoniosamente. Não faria sentido, por exemplo, aplicar o particionamento por micro-períodos progressivo no tempo para o digestor e o particionamento por micro-períodos regressivo no tempo para as máquinas de papel, pois as chances de gerar soluções infactíveis nas partições finais do processo serão elevadas. Além disso, verificar todas as combinações entre particionamentos se torna inviável e, portanto, optamos por verificar um conjunto menor de combinações. A Tabela 8 apresenta as combinações que serão verificadas durante os testes computacionais.

Tabela 8: Combinações de particionamentos da heurística relaxe-e-fixe testadas.

\begin{tabular}{|c|c|c|c|c|c|c|}
\hline \multicolumn{2}{|c|}{ Digestor } & P1 & P2 & P3 & $\mathrm{P} 4$ & $\mathrm{P} 5$ \\
\hline \multirow{8}{*}{ 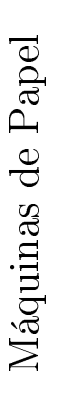 } & P1 & $\mathrm{X}$ & & & & $\mathrm{X}$ \\
\hline & P2 & $\mathrm{X}$ & & & & $\mathrm{X}$ \\
\hline & P3 & & $\mathrm{X}$ & & & $\mathrm{X}$ \\
\hline & $\mathrm{P} 4$ & & $\mathrm{X}$ & & & $\mathrm{X}$ \\
\hline & P5 & & & $\mathrm{X}$ & $\mathrm{X}$ & $\mathrm{X}$ \\
\hline & $\mathrm{P} 6$ & & & $\mathrm{X}$ & $\mathrm{X}$ & $\mathrm{X}$ \\
\hline & P7 & & & $\mathrm{X}$ & $\mathrm{X}$ & $\mathrm{X}$ \\
\hline & P8 & & & $\mathrm{X}$ & $\mathrm{X}$ & $\mathrm{X}$ \\
\hline
\end{tabular}

\subsection{Heurísticas do tipo fixe-e-otimize}

Heurísticas do tipo fixe-e-otimize (fix-and-optimize) são heurísticas de melhoria iterativa baseada no particionamento das variáveis de decisão do problema. Este tipo de abordagem foi inicialmente proposto para problemas de planejamento da produção por Pochet e Wolsey (2006) com o nome de Exchange. O nome fix-and-optimize foi cunhado nos trabalhos de Sahling et al. (2009) e Helber e Sahling (2010), onde o método foi aplicado ao problema de dimensionamento de lotes multi-estágio. Os autores propuseram particionamentos por itens, por recursos e por processo. Recentemente, esta abordagem tem sido utilizada em diversos trabalhos como, por exemplo, James e Almada-Lobo (2011), Santos e Almada-Lobo (2012), Xiao et al. (2013), Stadtler e Sahling (2013), Baldo et al. (2014) e Dorneles et al. (2014), onde são utilizadas para resolver o problema original. Outros trabalhos propõem a hibridização do fixe-e-otimize com outros métodos, como pode ser visto em Gören e Tunali (2014), Belo-Filho et al. (2015) e Furlan e Santos (2015), por exemplo.

Heurísticas do tipo fixe-e-otimize se diferenciam das heurísticas do tipo relaxe-e-fixe 
em dois pontos importantes. O primeiro ponto está relacionado ao objetivo do procedimento em si. A relaxe-e-fixe tem por objetivo gerar uma solução inicial de alta qualidade (heurística construtiva), visto que o esforço computacional dela é bem superior ao de heurísticas construtivas mais simples. A heurística fixe-e-otimize, por outro lado, tem o objetivo de melhorar uma solução inicial, baseando-se nas vizinhanças de busca geradas pelas partições das variáveis de decisão do problema (heurística de melhoria). O segundo ponto que diferencia os métodos é a forma como as variáveis são tratadas, pois no fixe-eotimize não utiliza-se a relação linear das variáveis inteiras do problema. Além disso, o fixe-e-otimize possibilita mesclar a utilização de diferentes tipos de particionamento como, por exemplo, aplicar particionamento por itens seguido de particionamento por períodos e outros, o que não faria sentido no caso da heurística relaxe-e-fixe.

A cada iteração do método, apenas as variáveis de decisão de um subconjunto serão liberadas para otimização, enquanto todas as demais variáveis particionadas são fixadas no valor da solução incumbente. Note que algumas variáveis podem não pertencer ao conjunto de variáveis abordadas pelo fixe-e-otimize. Neste caso o método não fixa estas variáveis em nenhum momento. Por exemplo, no caso do problema abordado, são particionadas apenas as variáveis binárias de decisão do digestor e das máquinas de papel. Todas as demais variáveis reais do problema, tal qual variáveis de nível de estoque, tamanho de cada micro-período, tamanho dos lotes de produção e outras, são determinadas nos sub-problemas resolvidos pela ferramenta de solução LP/MIP.

A expectativa do método é obter melhorias na solução incumbente pela resolução de sub-problemas fixados, até alcançar uma qualidade de alto nível. O método pode ser composto por uma única aplicação de cada partição (limitado a uma iteração), ou pode ser iterativamente resolvido até que todas as partições sejam aplicadas sem melhoria da solução incumbente (múltiplas iterações). Além disso, outras condições de parada, como tempo limite e máximo de iteração, podem ser utilizados para determinar o fim do processo de solução.

O particionamento das variáveis, no entanto, gera mínimos locais durante a resolução do problema. Estes mínimos locais podem ser evitados por meio de mudanças na sequência de aplicação das partições (JAMES; ALMADA-LOBO, 2011), perturbações da solução incumbente, utilizações de meta-heurísticas que controlam a aplicação das partições (FURLAN; SANTOS, 2015), ou ainda modificações da função objetivo, como será apresentado a seguir na Seção 4.5.3. 
Considere os conjuntos disjuntos de variáveis de decisão $Q^{r}, \operatorname{com} \bigcup_{r=1}^{R} Q^{r}=Q$ definidos na Seção 4.4. A cada iteração $i$, as variáveis do conjunto $Q^{i}$ são liberadas para otimização, enquanto as demais variáveis $\left(Q^{r}, \forall r \in R \mid r \neq i\right)$ são fixadas nos valores referentes as respectivas variáveis na solução incumbente. Se a solução do sub-problema fixado for melhor do que a solução incumbente, ela é salva como nova solução incumbente. Passa-se a próxima iteração, de acordo com a regra de precedência de aplicação das partições, até que um critério de parada seja satisfeito.

Neste trabalho foram desenvolvidas duas variantes da heurística fixe-e-otimize, sendo que ambas utilizam a mesma forma de particionamento das variáveis de sequenciamento da máquina de papel. As duas diferem na forma como as variáveis do digestor são tratadas. A primeira heurística é uma fixe-e-otimize aqui denominada "mais tradicional" por seguir o processo indicado em Sahling et al. (2009). O método de melhoria "alternativo", proposto neste trabalho, utiliza conhecimento específico do problema a fim de superar alguns mínimos locais gerados pela correlação entre os dois níveis de produção (digestor e máquinas de papel). Para evitar estes mínimos locais, são feitas mudanças na função objetivo durante as iterações do método. A forma de particionamento utilizada em ambas variantes é apresentada em mais detalhes na Seção 4.5.1. A heurística fixe-e-otimize tradicional (FT) pode ser encontrada na Seção 4.5.2 e a variante alternativa, com mudança de função objetivo (FFO), é detalhada na Seção 4.5.3.

\subsubsection{Particionamentos das variáveis de decisão das máquinas de papel}

O particionamento das variáveis usado nos métodos do tipo fixe-e-otimize são ligeiramente diferentes dos apresentados anteriormente. No caso da heurística relaxe-e-fixe, não faz sentido utilizar partições conflitantes, pois o processo consiste em criar uma solução inicial de forma iterativa. Um exemplo de partições conflitantes seria partições por períodos, seguidas de partições por itens. Neste contexto, tentaríamos fixar variáveis reais e relaxar variáveis inteiras. No contexto de melhoria do fixe-e-otimize, no entanto, a combinação de partições diferentes é muitas vezes aconselhável e promissor. Considerando que o particionamento das variáveis inteiras do problema gera conjuntos de sub-problemas com mínimos locais, o uso de múltiplos tipos de particionamento pode superar alguns destes mínimos locais, dado que eles podem diferir entre particionamentos distintos. Isto tende a melhorar a solução final e pode ser vantajoso, dependendo dos tipos de particionamento utilizados, da sequência de aplicação das partições e do tempo adicional necessário para 
a resolução das mesmas.

O particionamento das variáveis de decisão das máquinas de papel foi desenvolvido a fim de possibilitar qualquer forma de "cubo". Como as variáveis de controle da máquina de papel é representada como uma matriz tridimensional (três índices), podemos considera-lá como um cubo de dimensões $K \times T \times M$. Dentro deste cubo, cada partição pode ser vista como um cubo menor (sub-cubo). A partir desta definição, foram gerados três tipos de particionamento, sendo eles: particionamento por itens e máquinas; particionamento por períodos e máquinas; e particionamento por itens e períodos (denominado particionamento em forma de cubo). Outras variações, como combinações entre itens e máquinas ou períodos e máquinas, também podem ser construídas a partir da definição acima, porém elas não foram testadas nesta tese.

Para definir os particionamento desenvolvidos, primeiro é preciso definir alguns parâmetros. No caso da heurística relaxe-e-fixe, foram utilizadas apenas os parâmetros $T F$ e TS para definir os tamanhos das partições e sobreposições. Nas partições do fixe-eotimize, por outro lado, podem haver combinações que demandam tamanhos de partição para itens $(K)$, períodos $(T)$ e máquinas $(M)$. Neste caso, estende-se a definição de $T F$ utilizado para definir o tamanho das partições em relação aos períodos para $K F$ e $M F$. Da mesma forma, são definidos os parâmetros $K S$ e $M S$, em relação a $T S$.

\section{Particionamento por períodos e máquinas}

O particionamento por períodos e máquinas é feito por meio da definição de tamanho de partições (e sobreposições) destas dimensões na matriz de variáveis de preparação das máquinas. Neste caso, $K F$ é fixado na quantidade de gramaturas existentes $(K F=K$ e $K S=0)$. O particionamento por períodos e máquinas visa ajustar o planejamento da produção de todos os itens produzidos em um pedaço do horizonte de planejamento. Desta forma, os custos podem ser reduzidos com a inversão de itens produzidos entre micro-períodos adjacentes, ou mesmo pela substituição de itens produzidos por outros que são demandados, mas não estavam em produção na partição otimizada. Além disso, podem existir trocas de produção entre máquinas quando mais de uma máquina é considerada por partição. A Figura 41 ilustra um exemplo do particionamento por períodos e máquinas, no qual cada partição tem dois períodos $(T F=2)$, sete itens $(K F=7)$ e uma máquina $(M F=1)$. Neste exemplo, cada partição contém 14 variáveis de decisão e não existe sobreposição entre as partições.

2. Particionamento por itens e máquinas 


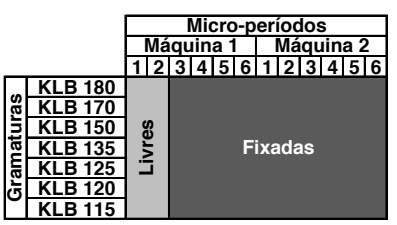

a) Partição 1

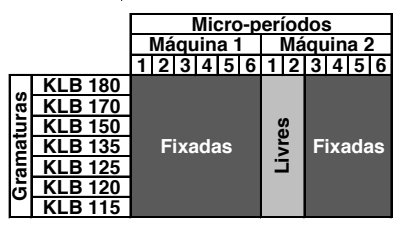

d) Partição 4

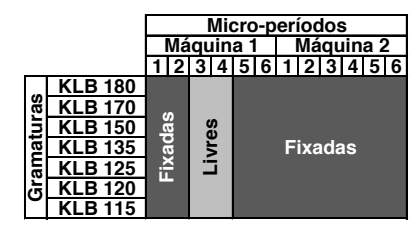

b) Partição 2

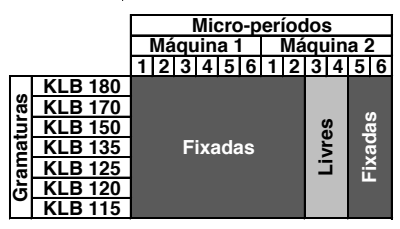

e) Partição 5

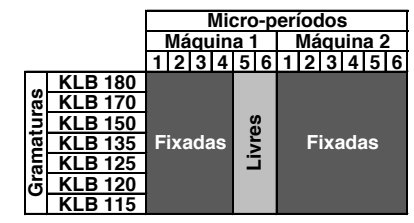

c) Partição 3

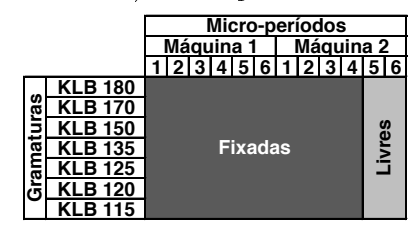

f) Partição 6

Figura 41: Particionamento por períodos das variáveis de controle das máquinas de papel.

O particionamento por itens e máquinas tem funcionamento semelhante ao particionamento por períodos e máquinas, diferindo em relação a qual dimensão da matriz de variáveis de preparação de máquina é fixada no valor máximo. Neste caso, TF é fixado no tamanho do horizonte de planejamento $(T F=S$ e $T S=0)$, pois não particionam-se as variáveis neste sentido da matriz. Este tipo de particionamento tem como objetivo otimizar o planejamento de produção para os itens liberados durante todo o horizonte de planejamento. Esta otimização pode ser feita reduzindo as preparações de máquinas, obtida por meio da agregação de múltiplas produções em um único período. Também podem ser geradas melhorias pela realocação e troca da produção de um ou mais itens na mesma máquina. A troca de produção entre máquinas também pode ocorrer quando mais de uma máquina for considerada na mesma partição. Os valores de $K F$ indicam o tamanho de cada partição em itens. A Figura 42 ilustra este tipo de particionamento, onde a forma das partições tem tamanho $K F=3, T F=6$ e $M F=2$, ou seja, tamanho $3 \times 6 \times 2=36$. Neste caso não foi considerada nenhuma sobreposição, ou seja, $K S=0, T S=0$ e $M S=0$.

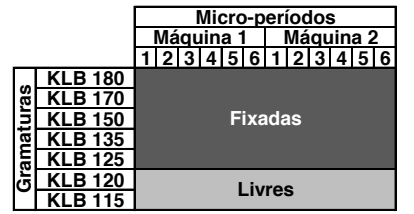

a) Partição 1

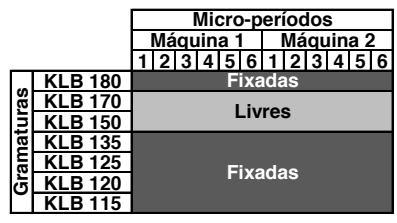

c) Partição 3

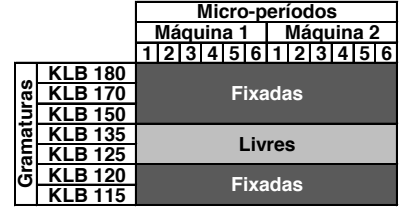

b) Partição 2

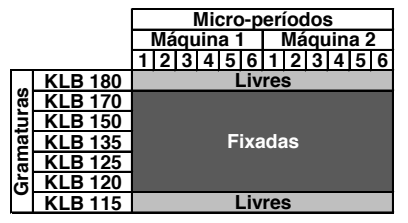

d) Partição 4

Figura 42: Particionamento por itens das variáveis de controle das máquinas de papel. 


\section{Particionamento em forma de cubo}

O terceiro e último tipo de particionamento é feito por itens e períodos (partições em forma de cubo) e foi construído com o objetivo de otimizar um agrupamento de variáveis que se encontram em uma região próxima. Dado que as restrições de balanceamento de estoque atrelam decisões ao longo do horizonte de planejamento e que as restrições de capacidade produtiva agregam as decisões de produção por períodos, otimizar uma região em formato de cubo pode se tornar vantajoso. O particionamento no formato de cubo é formado pela quantidade de máquinas de papel consideradas em cada partição $M F$ (fixadas) e pelas máquinas compartilhadas entre partições $M S$ (sobreposição), de forma similar ao ocorrido nos particionamentos por itens e micro-períodos. Além disso, também conta com as medidas destes dois últimos, $T F, T S, K F$ e $K S$. A Figura 43 apresenta um particionamento misto de períodos e itens. Neste caso o particionamento libera um grupo de variáveis que forma um pequeno cubo de dimensões $K F=4, T F=4$ e $M F=2$ e tem sobreposição de dimensões $K S=2, T S=2$ e $M S=0$. A ideia é otimizar situações em que existe a necessidade de troca de gramaturas em vários períodos simultaneamente, dado que este particionamento libera simultaneamente uma série de períodos e um sub-conjunto de gramaturas.

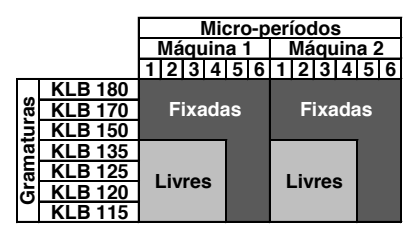

a) Partição 1

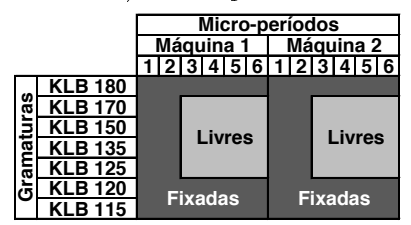

d) Partição 4

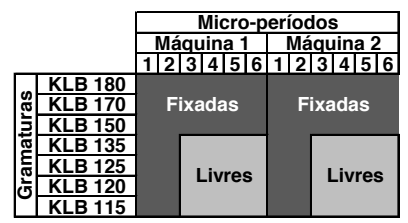

b) Partição 2

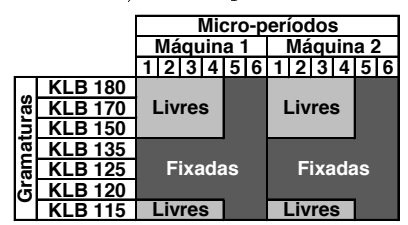

e) Partição 5

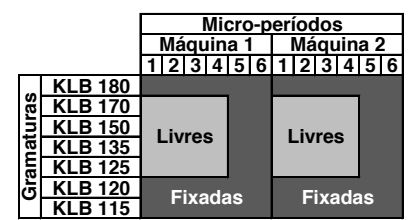

c) Partição 3

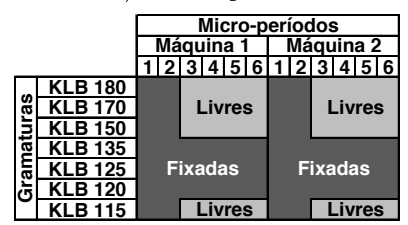

f) Partição 6

Figura 43: Particionamento em forma de cubo das variáveis de controle das máquinas de papel com sobreposição.

\subsubsection{Fixe-e-otimize tradicional}

A heurística fixe-e-otimize tradicional, baseada apenas no particionamento das variáveis de decisão, é composta por dois passos e um pseudo-código dela é apresentado no Algoritmo 4.7. O primeiro passo (linhas entre 5 e 13) consiste em iterativamente aplicar 
o particionamento nas variáveis de decisão da máquina de papel, com as variáveis de decisão do digestor fixadas nos valores obtidos na solução inicial. Isso significa que estamos aprimorando o sequenciamento das máquinas de papel para uma determinada sequência de velocidades do digestor. A velocidade do digestor define a quantidade de celulose virgem produzida e esta, por sua vez, acaba por limitar a produção das máquinas de papel. Após algumas iterações, o processo de melhoria estagna e nenhuma partição é capaz de gerar melhorias, terminando assim o primeiro passo. O segundo passo (linhas entre 14 e 27) consiste em liberar todas as variáveis de decisão do digestor (Linha 15) e voltar a aplicar iterativamente o particionamento sobre as variáveis de controle das máquinas de papel (linhas entre 16 e 25). Se uma solução de melhor qualidade for encontrada durante a execução deste passo (Linha 19), a solução é salva como incumbente (Linha 20). Se está solução for, ao menos, $\beta$ melhor que a solução incumbente (Linha 22), o segundo passo do método é interrompido, fixam-se as variáveis de controle da velocidade do digestor (Linha 26) e o método recomeça o primeiro passo. Note que na Linha 14 é feita uma verificação que somente autoriza o funcionamento do segundo passo quanto a solução encontrada no primeiro passo não for, pelo menos, $\beta$ melhor do que a solução incumbente. Enquanto houver uma melhoria mínima na solução incumbente, o segundo passo do método não é iniciado. Este procedimento em duas etapas é feito para reduzir o uso do segundo passo do método, computacionalmente mais pesado devido a quantidade elevada de variáveis livres. Além disso, a interrupção do segundo passo e retorno ao primeiro é feito, pois existe a possibilidade de novas melhorias, dado que a solução difere da anterior onde foram aplicadas as partições. Além disso, a sequência de velocidades do digestor é diferente da anterior, podendo limitar menos a sequência de produção da máquina de papel. A cada iteração completa do método é verificado se houve uma melhoria de pelo menos um fator $\gamma$ na solução incumbente. Caso esta melhoria seja maior, o processo contínua. Caso contrário, o processo termina e retorna a solução incumbente.

As variáveis de sequenciamento têm uma dependência forte entre si, devido a limitação de troca na velocidade exigida para manter a estabilidade do equipamento. Por este motivo, optou-se por fazer a liberação de todas as variáveis simultaneamente (Linha 15). Além disso, liberar apenas as variáveis do digestor para otimização não teria influência significativa sobre a solução, pois a influência do digestor sobre a função objetivo é bem reduzida. Esta influência é obtida pelo incentivo à produção de vapor do digestor e por limitar a produção de determinadas gramaturas, quando os estoques de celulose virgem se encontram próximos aos limites.

Como dados de entrada do método, são necessários a solução incumbente, os parâme- 


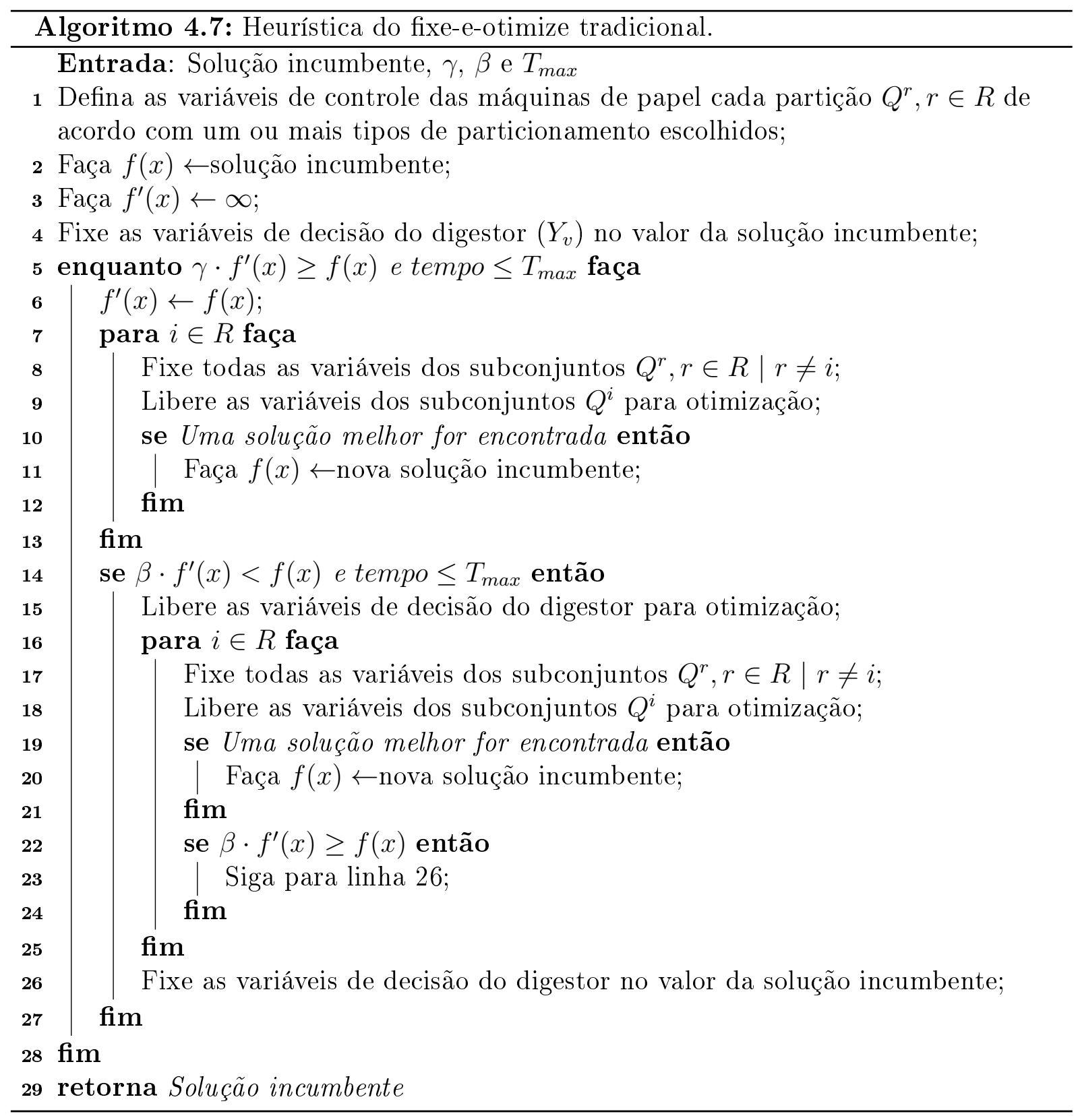

tros $\gamma$ e $\beta$, e o tempo limite. O parâmetro $\alpha$ define qual a taxa mínima de melhoria que desejamos para que o método possa continuar para a iteração seguinte (Linha 5). Por exemplo, se acharmos que não compensa continuar o procedimento após uma iteração com melhoria menor do que $1 \%$, definimos $\gamma=0.99$. O parâmetro $\beta$ tem funcionamento oposto, para definir quando resolver sub-problemas com as variáveis de controle do digestor liberadas (Linha 22). Se definirmos $\beta=0.98$, por exemplo, estamos considerando que se não houver melhoria de pelo menos $2 \%$ na solução incumbente após a aplicação de todas as partições, as variáveis de controle do digestor devem ser liberadas para otimização, juntamente com a aplicação das partições das variáveis de controle das máquinas de papel. 


\subsubsection{Fixe-e-otimize com mudança na função objetivo}

A heurística fixe-e-optimize alternativa, com mudança na função objetivo, foi motivada pela dificuldade de tratar o processo multi-estágio apresentada pela fixe-e-otimize tradicional durante os experimentos computacionais. $\mathrm{O}$ atrelamento da velocidade de micro-períodos consecutivos, que dificulta o particionamento das variáveis de decisão do digestor, combinado com as limitações que elas geram sobre as decisões de produção das máquinas de papel, diminui a flexibilidade das soluções geradas durante o processo de melhoria. Por outro lado, resolver sub-problemas com todas as variáveis de decisão do digestor liberadas é computacionalmente pouco eficiente no caso de exemplares de teste de grande porte e nem sempre geram melhorias nos resultados. Esta constatação motivou a construção desta variação do fixe-e-otimize. O Algoritmo 4.8 apresenta o pseudo-código da heurística fixe-e-otimize alternativa, com mudanças na função objetivo (FFO).

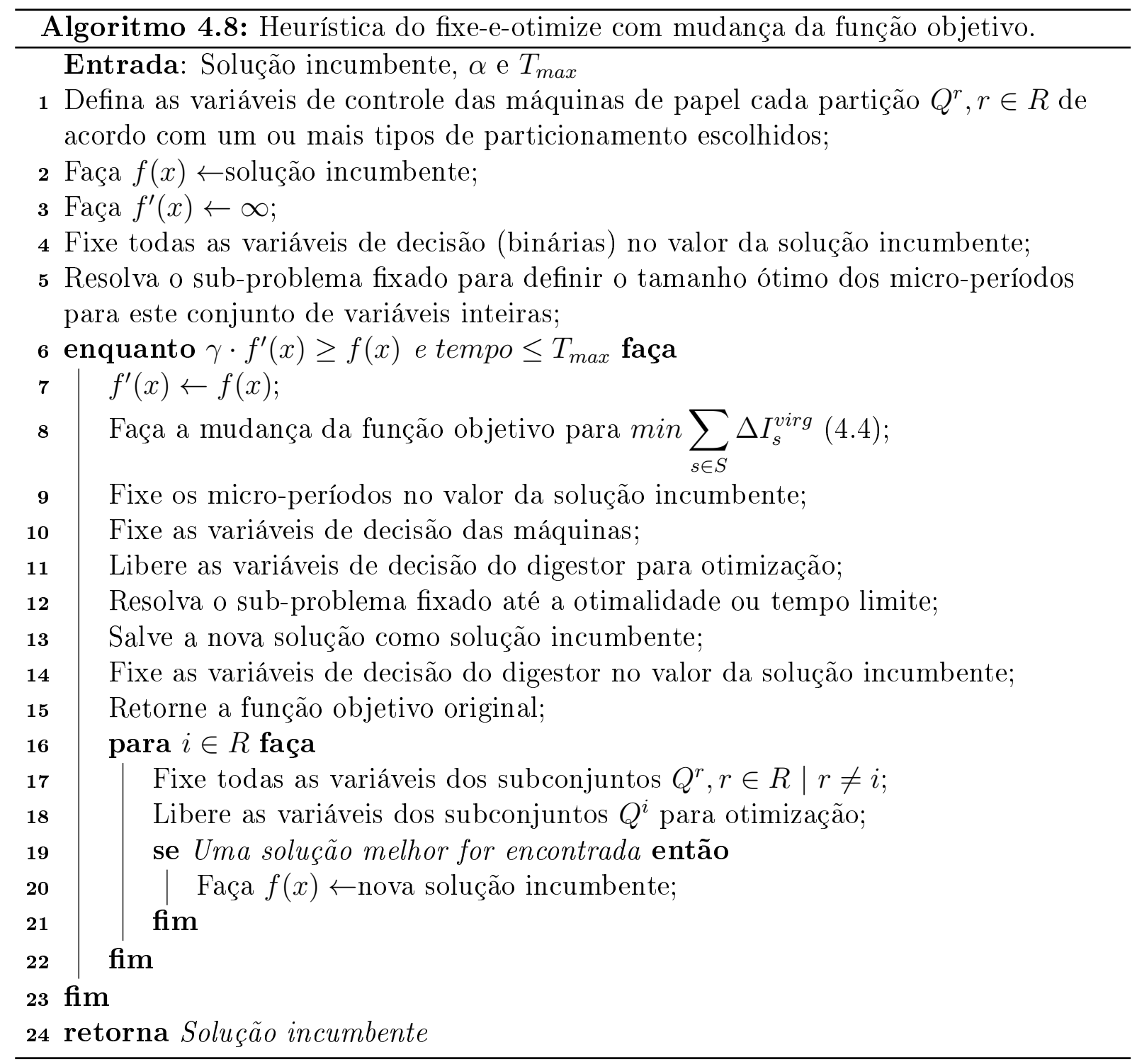


O FFO é idêntico ao método tradicional nos primeiros passos (linhas entre 1 e 3), onde é feita a construção das partições e inicialização dos valores de função objetivo do problema. Em seguida, nas linhas 4 e 5 definem-se os tamanhos dos micro-períodos com a solução de um sub-problema LP, onde todas as variáveis binárias do problema são fixadas. Estes valores são armazenados para posterior uso. A heurística FFO é composta por dois passos, como a heurística fixe-e-otimize tradicional. No entanto, neste caso, os dois passos são executados em todas as iterações do método. Os dois passos do método são os seguintes:

- Passo 1: Resolução de sub-problema com função objetivo considerando nível do tanque de celulose

O primeiro passo (linhas entre 8 e 14) consiste em modificar a função objetivo de forma a considerar o nível de estoque de celulose virgem como sendo o único recurso relevante no processo. Para tal, optamos por reescrever a função objetivo para gerar sequência de velocidades que façam com que o nível de estoque de celulose virgem se aproxime da média entre os limites máximo e mínimo deste estoque. De forma geral, podemos dividir os exemplares em três grupos com relação ao consumo de celulose virgem: exemplares com alta demanda de celulose virgem, exemplares com demanda média de celulose virgem e exemplares com baixa demanda de celulose virgem. Tanto o primeiro como o último caso terão dificuldades com os limites de estoque de celulose, sendo que o primeiro tende a ter soluções limitadas pelo nível mínimo (falta de celulose) e o último tende a ter soluções com altos níveis de estoque (excesso de celulose). A nova função objetivo tenta gerar velocidades que deixem o estoque mais próximo da média e, consequentemente, mais longe dos limites, aumentando a velocidade do digestor nos casos de alta demanda e diminuindo quando a demanda por celulose é escassa.

Para fazer a alteração na função objetivo, devemos adicionar mais um conjunto de variáveis e duas famílias de restrições, que farão a contabilidade da distância entre o nível de estoque de cada micro-período e o limite mais distante. Desta forma, minimizar a distância com relação ao limite mais distante é análogo a maximizar a proximidade com a média. As restrições a seguir foram adicionadas ao modelo:

$$
\begin{aligned}
& \Delta I_{s}^{\text {virg }} \geq I_{m a x}^{v i r g}-I_{s}^{v i r g} \\
& \Delta I_{s}^{\text {virg }} \geq I_{s}^{v i r g}-I_{m i n}^{v i r g}
\end{aligned}
$$




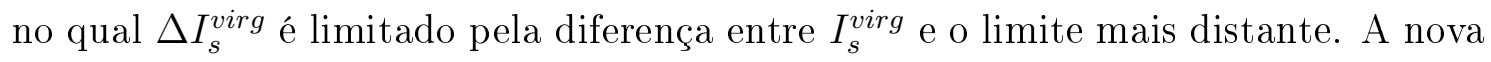
função objetivo é dada por:

$$
\min \sum_{s \in S} \Delta I_{s}^{v i r g}
$$

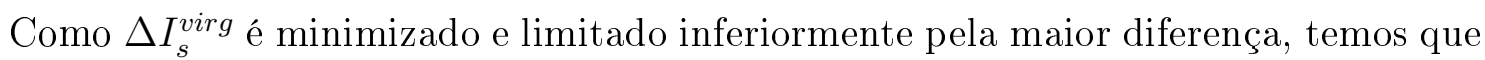
ele representa exatamente a maior diferença entre $I_{s}^{v i r g}$ e os limites de estoque de celulose virgem. Além disso, para evitar que o modelo matemático com função objetivo alterada se utilize da mudança de tamanho dos micro-períodos para minimizar a nova função objetivo e também para diminuir a complexidade do sub-problema gerado, faz-se a fixação dos tamanhos dos mesmos no valor da solução incumbente. Após otimizar este sub-problema até uma solução ótima ou quase-ótima, o processo fixa a nova solução de sequenciamento de velocidades do digestor e segue para o passo 2.

- Passo 2: Aplicação das partições para as variáveis de decisão das máquinas de papel com função objetivo original do problema

O segundo passo (linhas entre 15 e 22) representa o fixe-e-otimize aplicado às variáveis de decisão das máquinas de papel. Neste passo do método, os micro-períodos tem seus tamanhos liberados para otimização e a função objetivo original é restabelecida. Além disso, a solução de sequenciamento da velocidade do digestor é fixada de acordo com os respectivos valores da solução incumbente. O processo de melhoria das variáveis de controle das máquinas de papel é iniciado normalmente, aplicando todas as partições escolhidas, uma vez cada, de acordo com a sequência definida. Sempre que houverem melhorias, a solução incumbente é substituída (Linha 20) e a iteração seguinte terá como base a nova incumbente. Ao final da aplicação de todas as partições, o processo retorna ao primeiro passo do método e o método continua iterativamente, até que um critério de parada seja satisfeito. Os critérios de parada definidos no FFO são iguais aos definidos para o método tradicional (FT), apresentado na Seção 4.5.2. Se a solução não for, pelo menos, $\gamma \%$ melhor do que a incumbente ou o tempo limite for atingido, o método termina.

Os métodos apresentados neste capítulo, assim como o algoritmo híbrido apresentado no Capítulo 5 foram implementados e aplicados para resolver o problema em estudo. Os resultados obtidos com os testes computacionais destes métodos são apresentados e 
comparados no Capítulo 6. 
Este capítulo apresenta um método de solução híbrido, baseado em um algoritmo genético inicialmente proposto para tratar o problema de dimensionamento e sequenciamento de lotes de papel e celulose, como considerado aqui com o acréscimo da mistura de celulose reciclada para a produção de papéis. Conforme mencionado, este método foi publicado recentemente em Furlan et al. (2015) dentro do escopo desta tese de doutorado. Este método resolve simultaneamente o sequenciamento de velocidades do digestor e o sequenciamento de gramaturas das máquinas de papel. Como o método aborda o problema de forma híbrida, resolvendo o sequenciamento via algoritmo genético e um modelo de programação linear (LP) resultante pelo solver Cplex, a adaptação para o problema abordado nesta tese é direta. As restrições que fazem o controle referente à mistura da celulose reciclada nos produtos finais são resolvidas no sub-problema LP resultante. Removê-las é uma tarefa simples e não demanda mudança imediatas no algoritmo genético.

Os algoritmos genéticos tornaram-se mais populares a partir do trabalho pioneiro de Holland (1975). Muitos outros trabalhos se seguiram nas décadas seguintes, focados em novas variantes de algoritmos genéticos, novos operadores, aplicações em problemas reais, estudos sobre convergência do método e outras linhas de pesquisa. Um algoritmo genético básico é constituído por três partes principais: um método para gerar a população inicial (conjunto de soluções iniciais), um operador de seleção e um operador de recombinação (crossover). Este tipo de algoritmo genético é denomino algoritmo genético seleto-recombinativo (GOLDBERG, 2002). Existem ainda os operadores de mutação que são amplamente utilizados e podem ser combinados apenas com a seleção, em métodos de melhoria contínua (hill climbing) ou, como mais comumente encontrado, com seleção e recombinação. Um tutorial compreensivo sobre algoritmos genéticos foi apresentado em Whitley (1994), no qual variadas características do desenvolvimento de algoritmos 
genéticos são discutidos. Este tutorial trás discussões sobre a dificuldade dos problemas abordados por meio do estudo do cromossomo que os representa, de discussões sobre o espaço de soluções e de como o método trata este espaço, com base no teoria de esquemas (schemata theory). Whitley (1994) trás ainda discussões sobre operadores de recombinação, mutação e convergência prematura.

Goren et al. (2010) apresentam uma revisão sobre artigos que utilizam algoritmos genéticos no contexto de problemas de dimensionamento de lotes. Os autores fazem uma classificação dos trabalhos da literatura de acordo com as características do problema quanto ao tipo de horizonte de planejamento utilizado, estrutura de produtos utilizada (um ou mais níveis de produção) e restrições de capacidade de recursos, existência de tempo de preparação de máquina, entre outros. Em seguida, os autores discutem as características do algoritmo genético proposto com relação ao: tipo de população inicial, representação do cromossomo, operadores de cruzamento, operadores de seleção e operadores de mutação. Alguns exemplos de estudos recentes que aplicam algoritmos genéticos a problemas de dimensionamento de lotes são encontrados em Toledo et al. (2009), Santos et al. (2010), Amorim et al. (2011), Mohammadi et al. (2011), Camargo et al. (2012), Chan et al. (2012), Toledo et al. (2013) e Toledo et al. (2014).

O algoritmo genético proposto nesta tese para o problema de papel e celulose conta com algumas estruturas especiais para a resolução do problema, começando pela forma da decodificação do cromossomo. Uma parte do cromossomo é decodificado diretamente e a decomposição da outra parte é feita de forma indireta. Os cromossomos responsáveis pela decodificação do sequenciamento de produção das máquinas de papel é feito diretamente, por meio dos índices dos itens. Por outro lado, a decodificação do cromossomo responsável pelo controle de velocidade do digestor é feita de forma indireta para garantir a factibilidade de algumas restrições do problema. Além disso, o método também conta com um novo mecanismo de diversificação, baseado em medidas de similaridade dos indivíduos da população. Consideramos aqui que cada indivíduo representa uma solução do problema abordado. O mecanismo de diversificação tem o objetivo de reintroduzir características (alelos) perdidos no decorrer do processo de seleção. Alelos são definidos como partículas que compõe o cromossomo, ou seja, o valor que define a alocação de uma gramatura ou variação na velocidade a um micro-período. A perda desta diversidade pode ser ocasionada por conta da pressão de seleção excessiva, tipo de troca dos indivíduos ou ainda por conta da forma do espaço de soluções, entre outros fatores.

Além disso, o algoritmo genético também trata o problema de ajustar a quantidade 
de micro-períodos por período do horizonte de planejamento por meio da aceitação de indivíduos com quantidades diferentes de micro-períodos. Isto é feito com a adição de um "super-gene" que define quantos micro-períodos serão considerados durante a decodificação do indivíduo. Por exemplo, considere indivíduos com no máximo cinco micro-períodos em cada período e que exista um indivíduo $i$ com valor igual a três micro-períodos neste super-gene. Apenas os três primeiros alelos de cada período são considerados durante a decodificação do individuo $i$ e os demais são considerados inativos. Estes genes inativos podem ser habilitados nos descendentes do indivíduo $i$, seja por mutação do super-gene ou combinação com o alelo do super-gene de outro indivíduo durante o operador de cruzamento.

O algoritmo genético desenvolvido considera uma população inicial maior, para buscar soluções iniciais de melhor qualidade e soluções iniciais construídas por meio de heurísticas. Neste ponto, houve mudanças do método em relação ao algoritmo publicado em Furlan et al. (2015). No algoritmo genético proposto em Furlan et al. (2015) foi utilizada uma heurística construtiva baseada em arredondamento das variáveis inteiras. A partir da resolução de um problema de programação linear, resultante da relaxação linear das variáveis inteiras do problema, faz-se o sorteio dos alelos baseado nos valores reais obtidos. Esta heurística construtiva não apresentou resultados competitivos com as soluções construídas aleatoriamente (FURLAN et al., 2015). Além disso, como apresentado no Capítulo 6, a adaptação desta heurística construtiva (apresentada na Seção 4.2) também não foi competitiva em relação ao tempo computacional utilizado e, em alguns casos, o método não foi competitivo em relação a qualidade de solução com as demais heurísticas construtivas desenvolvidas aqui. No escopo desta tese, optamos então por adotar a heurística construtiva baseada em ciclos predefinidos de produção apresentada na Seção 4.3. Esta heurística foi adaptada para gerar soluções com variabilidade, como é apresentado em mais detalhes na Seção 5.2.1.

O algoritmo genético apresentado neste capítulo pode ser considerado um método híbrido, dado que a parte de decisão do problema (variáveis inteiras) é resolvida pela meta-heurística, enquanto que as demais variáveis do problema (variáveis reais) são otimizadas via ferramenta de solução de problema LP/MIP. Nesta implementação, utilizou-se a ferramenta comercial Cplex para esta tarefa. Métodos integrando (meta-)heurísticas e métodos exatos tem sido utilizados com sucesso em trabalhos recentes na literatura.

Segundo a classificação de Puchinger e Raidl (2005), a hibridização pode ser desenvolvida combinando os métodos de modo colaborativo ou integrado. As hibridizações 
integradas caracterizam-se por um método dominando o outro dentro da combinação. Esta integração varia de acordo com os métodos que são integrados e as tarefas que cada método exerce. Por outro lado, na hibridização colaborativa não existe um método mestre e todos colaboram de alguma maneira para construir ou melhorar as soluções do problema abordado. Pela classificação de Puchinger e Raidl (2005), o método híbrido aqui proposto pode ser classificado como integrado, dado que o método de solução exata é incorporado à meta-heurística para a resolução dos sub-problemas.

São utilizados neste algoritmo genético o operador de cruzamento de dois pontos e sete diferentes operadores de mutação, dos quais cinco são de propósito geral e dois exploram conhecimento específico do problema. O processo de diversificação baseia-se em uma nova medida de diversidade e em limites preestabelecidos, que indicam quando inciar e encerrar os processos de diversificação e intensificação durante a resolução do problema. Além disso, o processo de ajuste na quantidade de micro-períodos é obtida por meio da aceitação de indivíduos com número variável de genes ativos e inativos, adotando-se o super-gene de controle. O Algoritmo 5.1 apresenta um pseudo-código do método proposto.

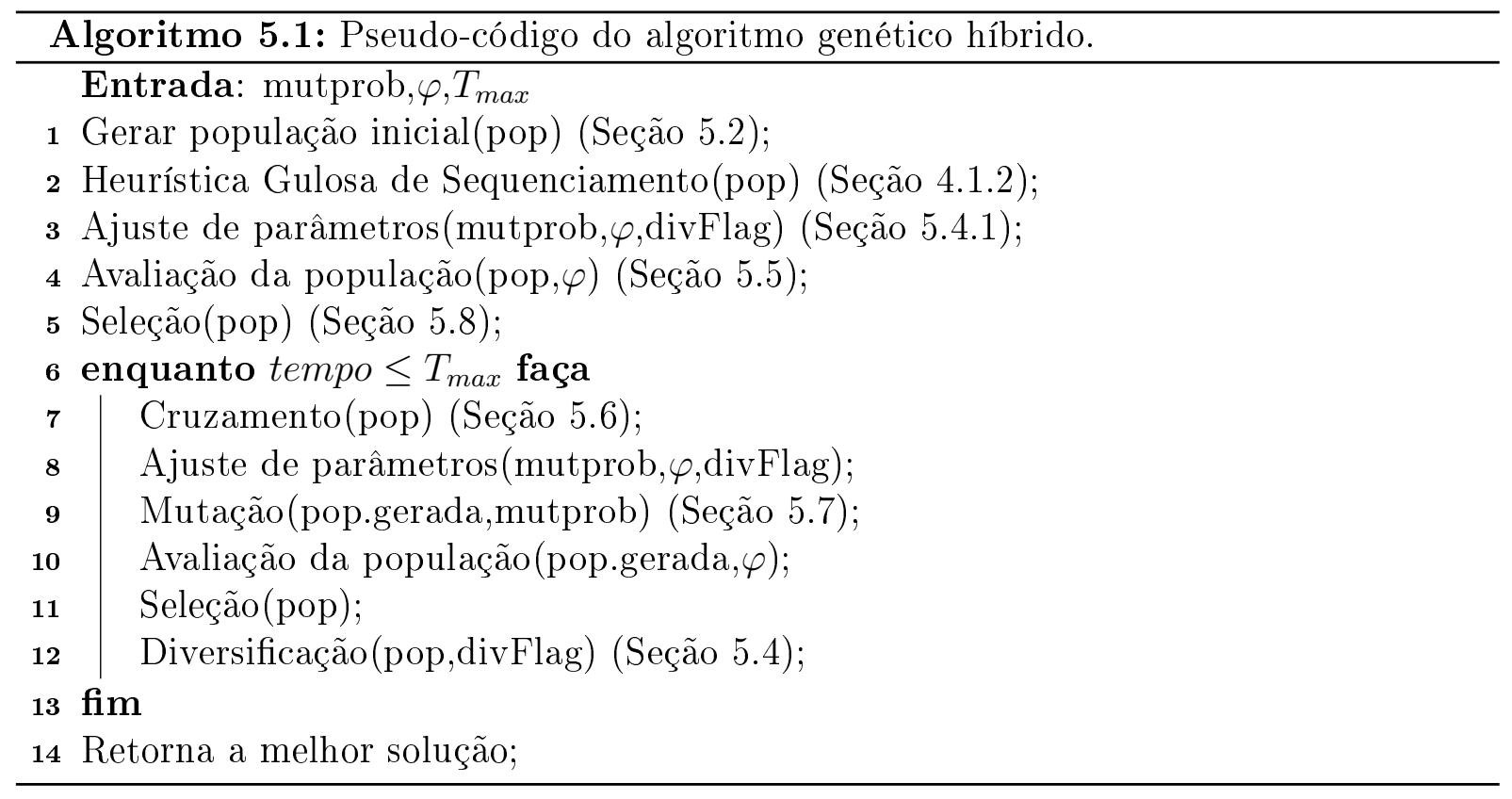

Como dado de entrada do método, temos a taxa de mutação inicial, a taxa de diversificação $(\varphi)$ e o tempo limite de solução. Tanto a taxa de mutação quanto a taxa de diversificação variam dentro de limites pré-estipulados pelo usuário, que podem ser ajustados de acordo com as características do problema abordado. Além destes parâmetros, o usuário deve estimar o tamanho da população, a probabilidade de cruzamento, a pressão de seleção e o uso das ferramentas desenvolvidas como processos de diversificação e ajuste da quantidade de micro-períodos. 
Para uma melhor apresentação dos componentes do algoritmo genético, o restante deste capítulo foi escrito da seguinte forma: a Seção 5.1 descreve a representação do indivíduo e a forma como é feito o ajuste na quantidade de micro-períodos. A Seção 5.2 apresenta a forma como a população inicial foi gerada, seja ela totalmente aleatória ou parcialmente gerada por uma heurística construtiva. A medida desenvolvida para verificar a diversidade da população é apresentada na Seção 5.3, juntamente com o processo de ajuste de parâmetros. A decodificação e o cálculo da função de aptidão são apresentados na Seção 5.5. A Seção 5.6 ilustra o operador de cruzamento utilizado e a Seção 5.7 detalha os operadores de mutação implementados. Finalmente, na Seção 5.8 apresentase o operador de seleção utilizado, e detalha-se as diferenças existentes nos processo de seleção para sobrevivência e para a escolha dos indivíduos para o processo de cruzamento.

\subsection{Representação do indivíduo}

O problema abordado integra o problema de sequenciamento das velocidades de trabalho do digestor e o sequenciamento e dimensionamento de lotes de produção de $M$ máquinas de papel. Em ambos os casos, o algoritmo genético aborda apenas o problema de sequenciamento, definindo padrões de fixação das variáveis binárias do problema. Em seguida, o sub-problema linear, resultante da fixação das variáveis binárias, é resolvido pelo método de solução exata.

A Figura 44 ilustra um exemplo de indivíduo com todas as características possíveis. Nesta imagem, as células em branco representam índices e valores calculados, as células em cinza (claro e escuro) representam genes do indivíduo e cada uma das linhas em cinza é denominada cromossomo e cada posição é chamada gene, em alusão aos respectivos grupos de informações contidos em um DNA. Cada gene pode conter um certo grupo de informações e a estas informações se dá o nome de alelo.

\begin{tabular}{|c|c|c|c|c|c|c|c|c|c|c|c|c|c|c|}
\hline \multicolumn{2}{|c|}{ Períodos } & 0 & \multicolumn{4}{|c|}{1} & \multicolumn{4}{|c|}{2} & \multicolumn{4}{|c|}{3} \\
\hline \multicolumn{2}{|c|}{ Micro-períodos } & 0 & 1 & 2 & 3 & 4 & 5 & 6 & 7 & 8 & 9 & 10 & 11 & 12 \\
\hline \multirow{2}{*}{ Digestor } & Variação & * & 2 & 3 & 4 & 2 & 1 & 0 & 2 & 3 & 1 & 1 & 3 & 4 \\
\hline & Velocidade & 12,0 & 12,0 & 12,5 & 13,5 & * & $\overline{13,0}$ & 12,0 & 12,0 & * & 11,5 & 11,0 & 11,5 & * \\
\hline \multicolumn{2}{|c|}{ PM 1 (gramaturas) } & * & 1 & 2 & 5 & 2 & 4 & 3 & 5 & 2 & 3 & 4 & 5 & 2 \\
\hline \multicolumn{2}{|c|}{ PM 2 (gramaturas) } & * & 1 & 1 & 3 & 3 & 5 & 4 & 3 & 1 & 3 & 2 & 6 & 4 \\
\hline
\end{tabular}

Figura 44: Representação de indivíduo com três micro-períodos ativos por período.

Na representação utilizada, fazemos a distinção de genes ativos e inativos por meio da intensidade de cinza que a representa. Os genes representados em cinza claro são genes ativos e estes são decodificados, influenciando diretamente sobre a aptidão do indivíduo. 
Por outro lado, os genes em cinza escuro (inativos) não são decodificados, não tendo influência imediata sobre o indivíduo. No entanto, estes genes são passados aos descendentes deste indivíduo que poderão ou não torna-los ativos, de acordo com o valor do super-gene. Desativar alguns genes tem o intuito de manter alguma diversidade, mesmo que estes alelos sejam momentaneamente prejudiciais à solução, sem ter uma penalização por isso. Os genes passivos são transmitidos entre gerações, podendo ser ativados em um momento futuro onde passem a ser vantajosos quando trabalharem em conjunto com outros genes que foram aperfeiçoados. No caso da Figura 44 o super-gene tem valor 3, ativando 3 genes em cada período de possíveis 4. Por exemplo, o sequenciamento da produção da máquina PM1 no exemplo da Figura 44 seria: 1,2,5,4,3,5,3,4,5.

Além da diferença nos problemas abordados entre os cromossomos que controlam a sequencia de produção das máquinas de papel e o cromossomo que controla a sequencia de velocidades do digestor, a sua codificação é feita de forma distinta devido a alguns conjuntos de restrições do problema. A codificação das sequências de produção das máquinas de papel é feita de forma direta, ou seja, o valor do alelo de cada gene é igual ao índice da gramatura que deve ser produzida no micro-período referente a este gene. Por exemplo, o alelo $1 \mathrm{em}$ um dos cromossomos referentes as máquinas de papel poderia ser a gramatura de menor peso $\left(115 \mathrm{~g} / \mathrm{m}^{2}\right)$. O cromossomo que controla a sequência de velocidades de trabalho do digestor, por outro lado, tem uma codificação indireta devido a limitação nas trocas das velocidades de trabalho do digestor. Para evitar infactibilidades no momento da decodificação, com relação a impossibilidade de troca de velocidade entre micro-períodos adjacentes (restrições 3.48), optou-se por utilizar a variação na velocidade como informação dos genes deste cromossomo (alelos).

Considerando que a variação máxima da velocidade de trabalho do digestor no sistema de passos discretos é dada por $\Delta$, o intervalo de velocidades do digestor tem $2 \cdot \Delta+1$ valores, pois são admitidas mudanças desde $-\Delta$ passos até $+\Delta$ passos, além da manutenção da velocidade anterior. Neste sentido, para evitar valores negativos na representação da solução, optamos por trabalhar com variações de 0 até $2 \cdot \Delta$. No momento da decodificação, fazemos apenas uma pequena translação de valores, onde o valor 0 representa uma redução na velocidade de $-\Delta, 1$ representa uma redução $-\Delta+1$, e assim por diante até $2 \cdot \Delta$, que representa um acréscimo na velocidade de $+\Delta$. Por exemplo, na Figura 44 foi considerado um $\Delta=2$ e uma discretização de 0, 5 RPM (Rotações por minuto), o que gera um total de 5 possibilidades de troca entre micro-períodos adjacentes. Um valor 0 indica uma redução de duas velocidades ou 1 RPM, enquanto um valor 3 representa um acréscimo de uma velocidade ou 0,5 RPM. 


\subsection{População inicial}

A forma mais comumente utilizada na literatura para gerar a população inicial de algoritmos genéticos é a geração aleatória de indivíduos. Por exemplo, no contexto de nosso indivíduo apresentado anteriormente, a geração aleatória consiste em escolher valores aleatoriamente obtidos para cada gene de todos os cromossomos. A cada micro-período, são sorteadas gramaturas para serem produzidas em cada máquina de papel e uma variação de velocidade para ser aplicada no digestor. Isto é feito para cada micro-período de forma independente, desconsiderando qualquer histórico ou informação do problema. Este tipo de geração de indivíduos resulta em alta taxa de diversidade na população, no entanto, não existe garantia de factibilidade nem de nível de qualidade dos indivíduos gerados.

Os indivíduos da população inicial também podem ser construídos de outras formas como, por exemplo, heurísticas construtivas específicas para o problema abordado, heurísticas para a resolução de problemas correlatos com a adaptação da solução, simplificação do problema para gerar indivíduos de qualidade mínima, entre outros. Isto tende a trazer indivíduos de melhor qualidade a população inicial, o que pode auxiliar no desempenho do algoritmo genético, principalmente em duas situações. A primeira situação ocorre na resolução de exemplares de teste muito grandes, onde mesmo a resolução da relaxação linear do problema é demorada. Neste caso, os sub-problemas lineares podem demandar muito tempo de solução, o que gera dificuldades de convergência do algoritmo genético em tempo computacional razoável. A segunda situação ocorre em exemplares nas quais encontrar soluções factíveis é uma tarefa complicada. Isto pode ocorrer em casos onde os limites de estoque intermediários são muito apertados, por exemplo.

Os dois tipos de soluções iniciais podem ainda ser combinados, de tal forma que possam haver ganhos de melhoria na qualidade de solução e na convergência do método, sem perdas significativas de diversidade na população. Como a heurística construtiva apresentada Furlan et al. (2015) não teve um bom desempenho aqui (ver experimentos computacionais no Capítulo 6), optamos por substituí-la por uma das heurística construtivas propostas no Capítulo 4. Mais precisamente, optamos por incluir a construção de soluções pela heurística construtiva baseada em ciclos de produção, apresentada na Seção 4.3. A adaptação deste método com a adição de aleatoriedade é apresentada na Seção 5.2 .1 . 


\subsubsection{Soluções iniciais não aleatórias}

A heurística construtiva baseada em ciclos foi utilizada por apresentar resultados de boa qualidade em tempo computacional adequado. Além disso, propicia uma introdução de aleatoriedade mais direta, sem que muitas alterações sejam necessárias. A aleatoriedade foi introduzida na escolha do ciclo de produção utilizado e no parâmetro $\alpha$, que indica a demanda necessária para alocar um micro-período de produção. Para cada indivíduo gerado via heurística para a população inicial do algoritmo genético, um valor de $\alpha$ e um dos possíveis ciclos de produção são aleatoriamente escolhidos. Na heurística construtiva apresentada na Seção 4.3, são geradas soluções para cada ciclo de produção e apenas a melhor é armazenada como incumbente. Nesta variante que obtém soluções iniciais para o algoritmo genético, no entanto, é necessário um conjunto de soluções construídas para serem integradas a população. Para cada ciclo de produção e valor de $\alpha$ escolhidos, a heurística gera uma solução ligeiramente diferentes e esta solução é adicionada ao conjunto de soluções iniciais não aleatórias. O processo continua iterativamente gerando soluções até que a população inicial construída via heurística esteja completa. A aleatoriedade na escolha do parâmetro $\alpha$ e na escolha do ciclo de produção utilizados visa manter a variabilidade da população. Por outro lado, a escolha de soluções construídas via heurística tem o intuito de melhorar a qualidade da população inicial, resultando em uma melhor convergência do método.

\subsection{Medida de dispersão de frequência dos alelos (FSM)}

A medida de dispersão de frequência dos alelos (Frequency Spread Measure ou FSM), é uma medida proposta para verificar a frequência combinada dos alelos de cada gene dentro da população. A ideia é verificar a dispersão de valores que são encontrados na população e combiná-los em uma medida que possa indicar qual a dispersão da população no espaço de solução, além de definir qual a aptidão de cada individuo para introduzir variabilidade à população. Para tal, devemos inicialmente definir a frequência de cada alelo presentes em cada indivíduo. Valores muito elevados desta frequência em determinados genes indicam que a população tem pouca variabilidade neste gene. Isto pode fazer parte da evolução da população, nos casos onde determinados genes tem valores específicos que geram melhoria significativa aos indivíduos. No entanto, pouca variabilidade em muitos genes pode indicar o fim do processo de evolução, ou ainda uma convergência prematura do algoritmo.

A frequência de dispersão dos alelos é calculada para cada gene $s$ de cada indivíduo 
$i$ da população pela seguinte formula: $\frac{(f r e q(s, g(s, i))-1)}{P o p s i z e-1}$, na qual $g(s, i)$ representa o alelo encontrado no gene $s$ do indivíduo $i, f r e q(s, g(s, i))$ representa a frequência deste alelo na população (número de ocorrências) e Popsize é o tamanho da população.

Baseado no cálculo das frequências dos alelos de cada gene, podemos calcular qual a parcela dos cromossomos que um indivíduo tem em comum com o restante da população. Esta medida foi denominada de Incapacidade Individual de Diversidade, do inglês Individual Diversity Incapacity (IDI). O IDI representa a média das frequências dos alelos contidos em um indivíduo e tem variação entre 0 e 1 . Um valor 0 representa uma capacidade completa de adição de diversidade, no qual nenhum outro indivíduo da população tem qualquer um dos alelos componentes deste indivíduo. No outro extremo, um valor 1 representa uma convergência completa do método, pois os alelos de cada gene são idênticos para todos os indivíduos, ou seja, a população seria composta apenas por indivíduos iguais. Quanto maior os valores de IDI encontrados nos indivíduos de uma população, menor a sua dispersão no espaço de solução, o que gera a necessidade do início do processo de diversificação.

A FSM é calculada como a média do IDI de todos os indivíduos da população e é usada para estabelecer o início e o final do processo de diversificação por meio de comparação com limites preestabelecidos pelo usuário. Como o problema é composto por dois problemas integrados de sequenciamento, o valor final de IDI de cada indivíduo é dado pelo maior valor entre o IDI dos cromossomos de controle da produção da máquina de papel e o valor de IDI do cromossomo de controle da velocidade do digestor (IDI= $\left.\max \left(I D I^{d i g}, I D I^{p m}\right)\right)$. Este valor de IDI é utilizado para computar o FSM da população.

Por exemplo, considere os 6 indivíduos da Tabela 9, compostos por 3 genes cada. No gene G1 temos que o alelo A1 aparece 4 vezes na população, enquanto os alelos A2 e A3 são encontrados em apenas um indivíduo cada. As frequência de cada alelo para cada gene são dados pela Tabela 10 .

Tabela 9: População com 6 indivíduos, 3 genes e 3 diferentes alelos.

\begin{tabular}{|c|c|c|c|c|}
\hline \multicolumn{2}{|c|}{ Genes } & G1 & $\mathrm{G} 2$ & G3 \\
\hline \multirow{6}{*}{$\Xi$} & I1 & $\mathrm{A} 1$ & $\mathrm{~A} 2$ & A3 \\
\hline & $\mathrm{I} 2$ & A1 & A1 & A3 \\
\hline & I3 & $\mathrm{A} 2$ & A3 & A1 \\
\hline & $\mathrm{I} 4$ & A3 & $\mathrm{A} 1$ & A2 \\
\hline & $\mathrm{I} 5$ & A1 & A3 & A3 \\
\hline & I6 & A1 & $\mathrm{A} 2$ & A2 \\
\hline
\end{tabular}


Tabela 10: Frequência dos alelos $(f r e q(s, g(s, i)))$ da população apresentada na Tabela 9.

\begin{tabular}{ccccc}
\hline Genes & G1 & G2 & G3 \\
\hline 号 & A1 & 4 & 2 & 1 \\
党 & A2 & 1 & 2 & 2 \\
A & 1 & 2 & 3 \\
\hline
\end{tabular}

O indivíduo I1, por exemplo, é formado pelos genes [A1,A2,A3] com frequências [4,2,3] (Tabela 9). O seu IDI é igual a $I D I(I 1)=\operatorname{media}\left\{\frac{4-1}{6-1} ; \frac{2-1}{6-1} ; \frac{3-1}{6-1}\right\}=0,4$. Por outro lado, o indivíduo I3 é composto pelos genes [A2,A3,A1] com frequências iguais a [1,2,1], respectivamente. O IDI do indivíduo I3 é de $\operatorname{IDI}(I 3)=$ media $\left\{\frac{1-1}{6-1} ; \frac{2-1}{6-1} ; \frac{1-1}{6-1}\right\} \approx 0,07$. Como o $I D I(I 1)>I D I(I 3)$, temos que I3 tem maior potencial de diversidade com relação a esta população. A FSM desta população é igual a média dos IDI dos indivíduos, sendo calculada da seguinte forma:

$$
F S M=\frac{0,4(I 1)+0,4(I 2)+0,07(I 3)+0,13(I 4)+0,4(I 5)+0,33(I 6)}{6} \approx 0,29,
$$

o que resulta em um valor baixo quando consideramos o limite máximo de 1 . Esta população ainda apresenta boa diversidade e pode evoluir por mais gerações antes que o processo de diversificação seja iniciado.

\subsection{Processo de diversificação}

A convergência prematura é um problema relevante no contexto de métodos de solução populacionais. A convergência, quando controlada, leva a evolução da população e soluções de melhor qualidade. No entanto, quando esta convergência torna-se prematura, o método pode ficar estagnado em soluções de baixa qualidade, dado que a população perde rapidamente a diversidade e passa a não ser mais capaz de combinar soluções de forma efetiva. Esta dificuldade pode ser ocasionada por excessiva pressão de seleção, elitismo elevado ou ainda por características do espaço de solução do problema. Koumousis e Katsaras (2006) e Vidal et al. (2012) propuseram diferentes métodos de diversificação.

O algoritmo genético proposto considera com um novo sistema de diversificação baseado na medida de dispersão de frequência de alelos (FSM) apresentada na Seção 5.3. O valor de FSM e dois limites ( $\overline{d t}$ and $\underline{d t}$ ) são utilizados para definir quanto o processo de diversificação tem início e quando deve terminar. O limite superior $(\overline{d t})$ define o ponto de saturação para o início do processo. Quando a FSM supera este valor $(F S M>\overline{d t})$, 
o processo de diversificação é iniciado. Por outro lado, quando a população atinge diversidade suficiente com $F S M<\underline{d t}$, o processo de diversificação é encerrado, reiniciando o processo de busca normal (intensificação). Assim que a diversidade for perdida, o processo de diversificação tem novo início e segue iterativamente. O estado atual do sistema a cada geração é indicado por divFlag. Quando divFlag tem valor verdadeiro, a diversificação está ligado. Por outro lado, quando divFlag é alterada para falso, a diversificação é desativada. O Algoritmo 5.2 apresenta um pseudo-código do processo de diversificação.

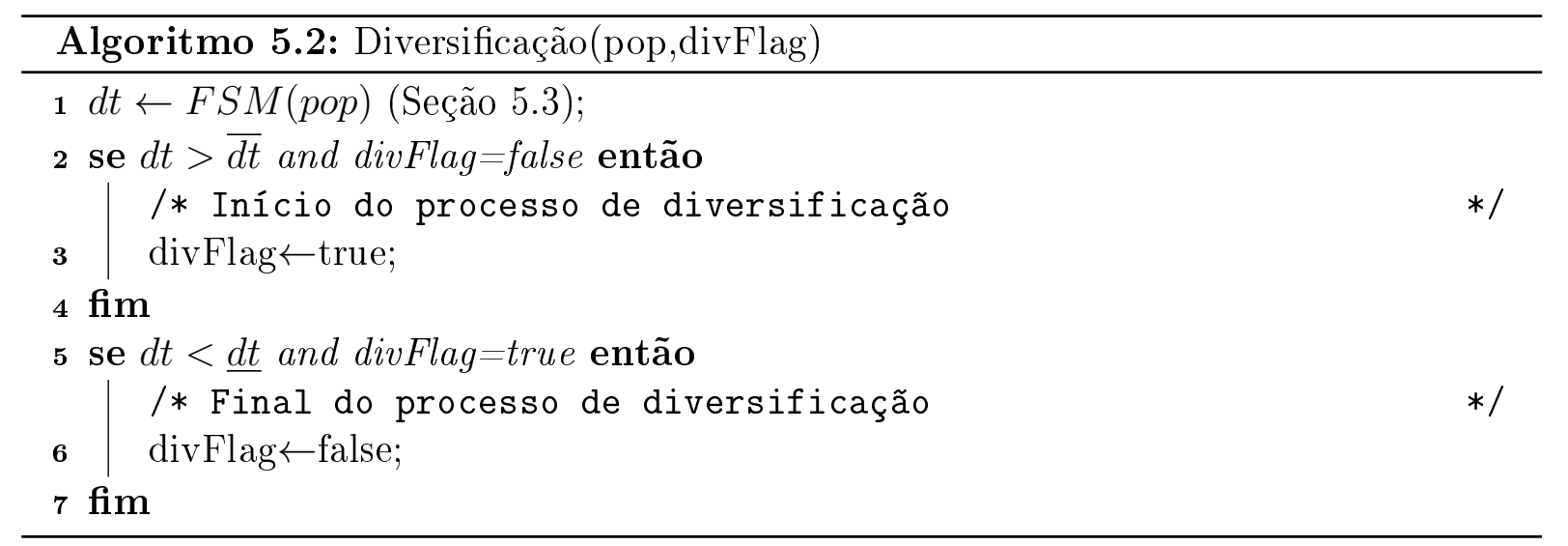

\subsubsection{Ajuste de parâmetros}

Dois parâmetros são responsáveis pela mudança de comportamento entre os processos de diversificação e intensificação do método de solução. O primeiro parâmetro é a taxa de mutação $\left(m u t^{p}\right)$, que é incrementada iterativamente até um limite máximo, assim que o processo de diversificação é iniciado. Quando o processo termina, a taxa de mutação é reduzida ao mínimo em uma única geração. O segundo parâmetro é a intensidade de diversificação $(\varphi)$, que é responsável por gerar uma penalização para os indivíduos com IDI elevado. O parâmetro $\varphi$ tem comportamento oposto ao da taxa de mutação, ou seja, no início do processo de diversificação, ele é aumentado para o seu valor máximo, sendo reduzido iterativamente após o final do processo de diversificação. O ajuste de parâmetros foi feito desta forma com o intuito de evitar que as soluções geradas para diversificar a população fossem perdidas logo após o final do processo de diversificação. Reduzindo gradualmente as vantagens destas soluções sobre as demais, tentamos garantir que estes indivíduos gerem descendentes mais competitivos e mais distintos na população.

O parâmetro $\varphi$ define a relação entre diversidade e qualidade de solução, definindo quanto o tomador de decisão está disposto a perder em qualidade de solução para adicionar um individuo com maior diversidade. $\mathrm{O}$ valor de $\varphi$ pode ser obtido da seguinte forma: 


$$
(1+\varepsilon)^{\varphi}=1+\psi
$$

no qual $\varepsilon$ indica a diversidade requerida para aceitar um aumento da função objetivo de $\psi$. O parâmetro $\psi$ é dado na forma de desvio percentual relativo entre as soluções $(f(x)$ e $\left.f\left(x^{\prime}\right)\right)$ que são comparadas $\left(\psi=\left|f\left(x^{\prime}\right)-f(x)\right| / \max \left(f\left(x^{\prime}\right), f(x)\right)\right)$. Como a diversidade de um indivíduo $\varepsilon$ é definida pelo IDI deste indivíduo, quanto maior o IDI, maior deve ser a penalidade. Esta fórmula pode ser modificada a fim de isolar $\varphi$, gerando a seguinte equação:

$$
\varphi=\frac{\ln (1+\psi)}{\ln (1+\varepsilon)}
$$

Uma função exponencial foi utilizada para penalizar os indivíduos com menor taxa de diversidade, pois o seu crescimento é mais acentuado com relação a própria similaridade. Quanto mais próximo de 1 (soluções iguais), maior será a taxa de crescimento da penalização. Além disso, um valor de $\varphi=0$ desliga o processo de diversificação, o que é necessário durante o processo de intensificação do método.

As probabilidades de mutação para cada gene também podem ser calculadas de acordo com a quantidade de genes e a probabilidade de mutação de cada indivíduo. A probabilidade de um indivíduo sofrer mutação é dada pela combinação das probabilidades de mutação de cada gene deste indivíduo. Se considerarmos que todos os genes de um indivíduo tem taxa de mutação igual a mut, para um indivíduo com cromossomo de tamanho $G S$, temos que a probabilidade de ocorrer mutação neste indivíduo é dada por:

$$
p=1-(1-m u t)^{G S}
$$

em que o fator $(1-m u t)$ na equação $(5.3)$ indica a probabilidade de não mutação de cada gene do indivíduo. Logo, $(1-m u t)^{G S}$ resulta na probabilidade do indivíduo não sofrer mutação, dado que combina a chance de nenhum dos genes deste indivíduo sofrer mutação. Analogamente, podemos definir a taxa de mutação de cada gene como sendo:

$$
m u t^{p}=1-(1-p)^{\frac{1}{G S}}
$$


no qual $m u t^{p}$ indica a taxa de mutação de cada gene para que o indivíduo tenha uma probabilidade de mutação de $p$. Calcular a taxa de mutação de cada gene a partir da probabilidade de mutação do indivíduo possibilita gerar quantidades similares de mutações por gerações para exemplares de tamanhos variados. Desta forma, podemos ajustar uma taxa de mutação que seja razoável para qualquer tamanho de exemplares. Por exemplo, se tivermos exemplares de teste que variam de 20 até 100 micro-períodos no horizonte de planejamento, teremos uma probabilidade de mutação por gene muito inferior nos exemplares com 120 micro-períodos. No entanto, a probabilidade de mutação dos indivíduos será parecida. As equações (5.4) podem ser utilizadas para definir os valores mínimo $\left(m u t^{\text {Min }}\right)$ e máximo de mutação $\left(m u t^{\text {Max }}\right)$, dadas as probabilidades mínima (Min) e máxima (Max) desejadas de mutação para cada indivíduo. Por exemplo, se desejarmos uma mutação mínima de $10 \%(p=0,1)$ para cada indivíduo em um exemplar com horizonte de planejamento de 20 micro-períodos $(G S=20)$, teremos mut $^{p}=1-(1-0,1)^{\frac{1}{20}}=1-0,9^{\frac{1}{20}} \simeq 0,53 \%$.

O Algoritmo 5.3 apresenta o processo completo de ajuste dos parâmetros. O parâmetro divIt é um dado de entrada que indica o número de gerações utilizadas no aumento da taxa de mutação no início do processo de diversificação e o número de gerações utilizadas na redução de $\varphi$ após o final do processo de diversificação. Os valores $\varphi^{\text {Min }}$ e $\varphi^{\text {Max }}$ podem ser obtidos pela equação (5.2) a fim de garantir o intervalo de trabalho do processo de diversificação. Para obter os valores de $\varphi^{\text {Min }}$ e $\varphi^{\text {Max }}$ desta forma, basta definir os limites mínimos e máximos que se está disposto a aceitar de piora na qualidade dos indivíduos da população $(\psi)$ e o incremento na diversidade desejado para aceitar tais pioras $(\varepsilon)$.

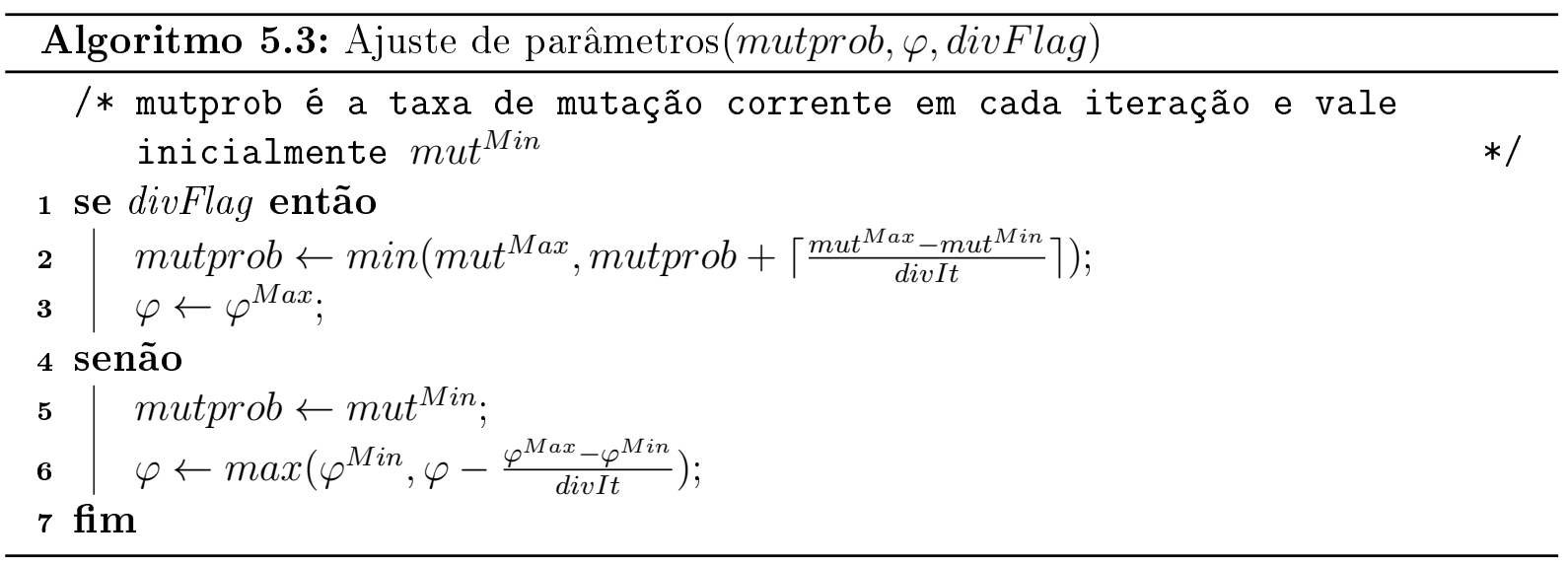




\subsection{Decodificação e avaliação de aptidão dos indivíduos}

Cada indivíduo codifica uma solução completa, combinando as soluções do problema de sequenciamento das velocidades do digestor e dos problemas de sequenciamento da produção das múltiplas máquinas de papel. A decodificação destes dois problemas é feita de forma distinta, devido às características e necessidades de cada sistema produtivo. A decodificação da sequência de produção das máquinas de papel é feita de forma direta, ou seja, o valor de cada alelo se refere ao índice da gramatura produzida no micro-período e máquina controlados pelo gene correspondente. Por exemplo, na Figura 44 temos o cromossomo PM1 composto pelos alelos [1,2,5] no primeiro período. A máquina de papel PM1 terá sua sequência de produção começando pela gramatura de índice 1, passando pela gramatura 2 e terminando na gramatura de índice 5, neste período. Em seguida, inicia o segundo período pela gramatura 4 e segue a decodificação até o final do cromossomo. Veja que a gramatura referente ao quarto micro-período de cada período está inativa e, portanto, será ignorada durante a decodificação do indivíduo.

A sequência de velocidades do digestor, por outro lado, tem decodificação indireta. No caso do cromossomo refente ao digestor, cada alelo corresponde a variação da velocidade de trabalho do digestor, de acordo com os passos de discretização dados no exemplar de teste do problema (Figura 44). A velocidade de cada micro-período $s$ é definida por duas informações, sendo elas: a velocidade de trabalho do micro-período $s-1$ e a variação desejada (valor de alelo do gene responsável pelo controle da velocidade de $s$ ). Como o intervalo de valores dos alelos foi transladado para evitar valores negativos, temos que considerar esta translação no momento de decodificar as velocidades (Seção 5.1). Podemos definir a velocidade de trabalho do digestor no micro-período $s$ pela seguinte equação:

$$
V_{s}=V_{s-1}+(d v(s, i)-\Delta) \cdot \Phi
$$

na qual $d v(s, i)$ faz referência ao valor de alelo encontrado no gene $s$ do indivíduo $i$ no cromossomo de controle de velocidade do digestor, $\Delta$ é o limite do intervalo de troca entre velocidades consecutivas (para cima ou para baixo) e $\Phi$ é a discretização usada para gerar os passos de mudança na velocidade do digestor. É importante lembrar que a velocidade de trabalho deve ser limitada aos valores mínimos e máximos de trabalho do digestor, o que é verificado a cada micro-período. Se um dos limites for violado, o valor calculado é substituído pelo limite violado, ou seja, se a velocidade de trabalho atual de $s-1$ for 
igual a velocidade máxima de funcionamento, por exemplo, não poderemos aumenta-la mesmo que isso seja requerido no alelo referente a $s$. Portanto, o digestor trabalhará na velocidade máxima no micro-período $s$. Por exemplo, na Figura 44, para calcular a velocidade do micro-período 3 , temos os seguintes dados: $V_{2}=12,5, d v(3, i)=4, \Delta=2$ e $\Phi=0,5$. Pela equação $(5.5)$ temos que $V_{s}=12,5+(4-2) \cdot 0,5=13,5$.

O problema resultante da fixação das variáveis de sequenciamento $\left(Y_{v s}^{\text {dig }}, Y_{j s m}\right.$ e $\left.Z_{k j s m}\right)$ é um problema de programação linear que pode ser definido a partir do modelo matemático (3.45)-(3.74). Algumas restrições podem ser removidas por serem garantidas pela codificação do indivíduo, mais precisamente as restrições (3.47), (3.48), (3.62), (3.63) e (3.64). O problema linear resultante é resolvido utilizando uma ferramenta de solução de problemas lineares. Nesta tese foi utilizado o Cplex para esta tarefa.

\section{Aptidão dos indivíduos da população}

A função (5.6) é responsável pelo cálculo da aptidão dos indivíduos da população, sendo composta pelo produto das seguintes parcelas:

1. A primeira parcela é composta pelo valor de $f(p)$ dividido por $(\bar{f})$. O valor de $f(p)$ é gerado pela decodificação do indivíduo $p$ e calculada pela função objetivo (3.74). Por outro lado, $\bar{f}$ é obtido por meio da média da função objetivo $(f(q))$ para todo indivíduo $q$ pertencente a população;

2. A segunda parcela é obtida dividindo a soma de infactibilidades do indivíduo (calculada pela função (5.8), quando existir infactibilidade), denominada $u(p)$, pela infactibilidade média $(\bar{u})$. Ao valor resultante soma-se um, para garantir a neutralidade desta parcela quando não há infactibilidade. Mais detalhes sobre o tratamento de infactibilidades podem ser encontrados na Seção 5.5.1;

3. A última parcela é utilizada apenas durante o processo de diversificação e em sua finalização. Neste caso, o responsável pelo desligamento da parcela é o parâmetro $\varphi$, que quando igualado a zero faz com que o resultado da terceira parcela se iguale a um. Quanto maior o valor de $\varphi$, maior será a influência da medida de dispersão $I D I(p)$.

$$
\operatorname{finess}(p)=\frac{f(p)}{\bar{f}} \cdot\left(1+\frac{u(p)}{\bar{u}}\right) \cdot(1+I D I(p))^{\varphi}
$$




\subsubsection{Tratamento de infactibilidades}

Soluções infactíveis são aceitas em uma população para tentar manter a variabilidade desta população e ampliar o espaço de soluções do método. De acordo com Michalewicz (1995), as infactibilidades podem ser tratadas de diferentes formas como, por exemplo: rejeitar soluções infactíveis, reparar soluções infactíveis, ou penalizar soluções infactíveis. Neste algoritmo genético, optou-se por penalizar as soluções infactíveis a fim de mantê-las parcialmente na população, sem causar distúrbios em suas características principais. A soma das infactibilidades $(u(p))$ é dada pela soma de variáveis de folga, adicionadas às restrições de controle de estoque de celulose virgem (3.54), às restrições de estoque de licor negro fraco (3.55), às restrições de tamanho mínimo requirido nos micro-períodos (3.60) e às restrições de tamanho mínimo de lote de produção (3.65). O modelo (5.7)(5.12) utilizado para contabilizar a soma de infactibilidades diferencia-se do modelo ()-() pelo acréscimo das variáveis de folga associados a cada tipo de infactibilidade tratada. O modelo (5.7)-(5.12) relaxado é apresentado a seguir:

$$
\begin{aligned}
\text { min } & f(p)+\Omega \cdot u(p) \\
\text { s.to }: & f(p)=(3.74), \\
& u(p)=\vartheta \cdot \sum_{s \in S}\left(I_{s}^{\text {virg }(+)}+I_{s}^{\text {virg }(-)}\right)+\delta \cdot \sum_{s \in S}\left(I_{s}^{\text {liquor }(+)}+I_{s}^{\text {liquor }(-)}\right) \\
& +\tau \sum_{s \in S} N_{s}^{(+)}+\eta \sum_{s \in S} X_{j s m}^{\text {slack }} \\
& (3.45)-(3.53),(3.56)-(3.59),(3.61)-(3.64),(3.66)-(3.73), \\
& N_{s} \geq N_{\text {min }} \cdot\left(Y_{v s}^{\text {dig }}-Y_{v, s-1}^{\text {dig }}\right)-N s^{(+)}, v \in V, s \in S, \\
& X_{s}^{\text {dig }}+I_{s-1}^{\text {virg }}+I_{s}^{\text {virg }(+)}=\sum_{m \in M} O_{\text {sm }}^{\text {virg }}+I_{s}^{\text {virg }}+I_{s}^{\text {virg }(-)}, s \in S, \\
& X_{s}^{\text {liquor }}+I_{s-1}^{\text {liquor }}+I_{s}^{\text {liquor }(+)}=O_{s}^{\text {liquor }}+I_{s}^{\text {liquor }}+I_{s}^{\text {liquor }(-)}, s \in S, \\
& m_{j m} \cdot\left(Y_{j s m}-Y_{j, s-1, m}\right) \leq X_{j s m}+X_{j s m}^{\text {slack }}, j \in K, s \in S, m \in M .
\end{aligned}
$$

no qual a restrição (5.7) combina a função objetivo original, dada por $f(p)$, com a soma de infactibilidades $u(p)$ ponderada por um parâmetro $\Omega$. A restrição (5.8) é responsável pela soma das infactibilidades, que são ponderadas de acordo com o tipo de acréscimo/decréscimo que cada variável proporciona. As restrições (5.9) fazem o controle dos tamanhos mínimos de micro-períodos necessários para que trocas na velocidade do digestor possam ser aceitas. Nestas restrições foram adicionadas variáveis de falta $N_{s}^{(+)}$, que 
são ponderadas pelo parâmetro $\tau$, na restrição (5.8). As restrições (5.10) são responsáveis pelo balanceamento de estoque da celulose virgem. Para estas restrições foram associadas variáveis de falta $\left(I_{s}^{v i r g(+)}\right)$ e excesso $\left(I_{s}^{\text {virg(-) }}\right)$ de celulose virgem, que garantem a factibilidade das mesmas. Estas variáveis de falta e excesso são associadas ao parâmetro $\vartheta$, na restrição (5.8). De forma similar, as restrições (5.11) fazem o balanceamento de estoque do licor negro fraco e suas faltas $\left(I_{s}^{\text {liquor }(+)}\right)$ e excessos $\left(I_{s}^{l i q u o r(-)}\right)$ são ponderados na restrição (5.8) pelo parâmetro $\delta$. As restrições (5.12) obrigam a produção de lotes mínimos de papel sempre que houver trocas de preparação de máquina. Nestas restrições foram adicionadas variáveis de falta $X_{j s m}^{\text {slack }}$. Na restrição (5.8) foi associado o parâmetro $\eta$ a este tipo de infactibilidade.

\subsection{Operador de cruzamento}

O operador de cruzamento é responsável pela mistura dos genes dos indivíduos, a fim de produzir novos indivíduos que possam atingir melhores resultados do que seus progenitores. O processo de evolução da população se dá por esta iterativa mistura dos alelos dos indivíduos, dos quais são selecionadas as melhores soluções a cada geração. Variados trabalhos discutem e propõem novos operadores de cruzamento utilizando diferentes perspectivas. Uma destas perspectivas é a teoria de blocos de construção (GOLDBERG, 2002; WHITLEY, 1994; GOLDBERG, 1990). Esta teoria estuda como soluções de boa qualidade são construídas por meio da combinação iterativa de alelos, que compõem soluções de alta qualidade. Em termos gerais, blocos de construção são sub-conjuntos de genes com valores de alelos que trazem melhorias a todos os indivíduos que os contém, independente dos demais genes. No início do processo evolutivo, esses blocos tem tamanho reduzido e com o passar das gerações, eles crescem até formar grandes blocos que, combinados, geram soluções de alta qualidade. Dependendo do tipo de operador de cruzamento usado, temos uma aceleração na criação e manutenção destes blocos de construção.

No algoritmo genético proposto, utilizamos o operador de cruzamento de dois pontos, que tende a perturbar menos as soluções geradas. Este distúrbio foi estudado por Spears e Jong (1990), e os autores demonstram que este operador trata o cromossomo como um anel, considerando que o início do cromossomo pode ser ligado ao seu final. Desta forma, um bloco de construção composto por alelos encontrados nos genes do início e do final do cromossomo terá mais chances de ser preservado. Os autores demonstram que este operador de cruzamento perturba menos as soluções do que o operador de cruzamento uniforme e do que operadores com quantidade maior de pontos (n-pontos). 
Devido a consideração de indivíduos com quantidades de genes ativos distintos, o operador de cruzamento faz uma combinação completa entre os genes de ambas as soluções. A quantidade de genes ativos, definida pelo super-gene, também é considerada como hereditária. No caso de cruzamento entre indivíduos de tamanhos distintos, temos que cada um dos dois filhos gerados receberá o super-gene de um dos pais. Por exemplo, se um dos pais possui três de quatro micro-períodos por dia (um gene inativo por dia) e o outro pai possui apenas dois micro-períodos, um dos filhos terá valor no super-gene de dois enquanto o outro terá valor igual a três.

Cada indivíduo possui $M+1$ cromossomos, sendo um responsável pelo sequenciamento de velocidades do digestor e os demais $M$ responsáveis pelo sequenciamento de produção das $M$ máquinas de papel. Por exemplo, na Figura 44 existem duas máquinas $(M=2)$, totalizando três cromossomos. Para cada um destes cromossomos, são escolhidos dois pontos aleatórios para fazer o cruzamento, ou seja, os pontos de quebra dos cromossomos não serão necessariamente os mesmos.

\subsection{Operadores de mutação}

Um operador de mutação tem como objetivo adicionar alguma variabilidade à população e retornar alelos perdidos durante o processo evolutivo. Isto faz com que o operador torne-se complementar ao operador de cruzamento, pois cada um possibilita buscas em espaços de solução não alcançáveis em poucas gerações pelo outro.

Foram implementados sete operadores de mutação, sendo cinco deles operadores de propósito geral, um relacionado ao ajuste na quantidade de micro-períodos e um construído a partir de conhecimento especifico do problema. Todos estes operadores têm diferentes probabilidades de mutação, visto que atuam de formas diferentes e são executados com probabilidades distintas de aplicação. Os operadores de mutação são aplicados ordenadamente, iniciando pelos que causam mais perturbação na solução. Isto significa que, dependendo das taxas de mutação, todos os operadores tem alguma probabilidade de serem aplicados a um mesmo indivíduo. A Tabela 11 apresenta a frequência de aplicação e o nível de perturbação gerado na solução por cada um dos operadores de mutação. Estes operadores são apresentados em mais detalhes a seguir.

1. Mutação simples

Quando um gene é aleatoriamente selecionado para sofrer mutação, um alelo diferente daquele que atualmente se encontra no gene é escolhido para tomar o seu 
lugar. A Figura 45 apresenta uma ilustração desta mutação, na qual o gene selecionado para sofrer mutação tem o alelo 3 de um conjunto de 8 possíveis alelos $([1,8])$. Neste caso, a mutação gerou um alelo 7, mas poderia ter gerado um valor aleatório no conjunto $[1,2] \bigcup[4,8]$.

\begin{tabular}{|c|c|c|c|c|c|c|c|c|c|c|}
\hline \multicolumn{2}{|c|}{ Períodos } & \multicolumn{3}{|c|}{1} & \multicolumn{3}{|c|}{2} & \multicolumn{3}{|c|}{3} \\
\hline \multicolumn{2}{|c|}{ Micro-períodos } & 1 & 2 & 3 & 4 & 5 & 6 & 7 & 8 & 9 \\
\hline \multirow{2}{*}{ PM1 } & Antes & 1 & 2 & 5 & 4 & 3 & 5 & 3 & 4 & 5 \\
\cline { 2 - 11 } & Depois & 1 & 2 & 5 & 4 & 7 & 5 & 3 & 4 & 5 \\
\hline
\end{tabular}

Figura 45: Exemplo de mutação simples.

\section{Mutação de troca}

A mutação de troca faz a inversão dos alelos entre dois genes com um cromossomo de mesmas características. Após um gene ser sorteado para sofrer esta mutação, outro gene é sorteado aleatoriamente dentro do mesmo cromossomo, ou de cromossomos com mesmas características. Isso significa que a troca somente poderá ocorrer entre genes que controlam a sequência de produção da máquina de papel, ou entre genes que controlam a velocidade do digestor, não sendo aceitas trocas entre os grupos. A Figura 46 apresenta um exemplo da mutação de troca, na qual os genes 3 e 5 são sorteados para terem seus alelos trocados. Quando os genes selecionados para mutação tem alelos de mesmo valor, a mutação simples é aplicada ao primeiro gene selecionado para mutação. Como a troca entre genes com mesmo alelo não geraria mudança, optou-se por obrigar a modificação, pois o gene foi selecionado para mutação.

\begin{tabular}{|c|c|c|c|c|c|c|c|c|c|c|}
\hline \multicolumn{2}{|c|}{ Períodos } & \multicolumn{3}{|c|}{1} & \multicolumn{3}{|c|}{2} & \multicolumn{3}{|c|}{3} \\
\hline \multicolumn{2}{|c|}{ Micro-períodos } & 1 & 2 & 3 & 4 & 5 & 6 & 7 & 8 & 9 \\
\hline \multirow{2}{*}{ PM1 } & Antes & 1 & 2 & 5 & 4 & 3 & 5 & 3 & 4 & 5 \\
\cline { 2 - 11 } & Depois & 1 & 2 & 3 & 4 & 5 & 5 & 3 & 4 & 5 \\
\hline
\end{tabular}

Figura 46: Exemplo de mutação de troca.

\section{Mutação por inserção}

A mutação por inserção causa maior distúrbio no indivíduo, dado que gera um deslocamento nos genes. Como esta mutação pode modificar uma série de alelos do cromossomo que sofre mutação, ela poderá ser aplicada no máximo uma vez por cromossomo, ou seja, no máximo $M+1$ vezes por indivíduo (Figura 44). Quando um cromossomo do indivíduo é selecionado para sofrer esta mutação, dois genes são selecionados aleatoriamente dentro do cromossomo como pontos de inserção e remoção. Além disso, um valor de alelo $v$ também é gerado aleatoriamente para ser 
inserido na sequência. O valor $v$ é inserido na posição de inserção e todos os alelos são deslocados em uma posição para a frente, até o ponto de remoção. O valor do alelo anteriormente posicionado no ponto de remoção é eliminado da sequência, a fim de manter o tamanho da sequência. A Figura 47 ilustra um exemplo de mutação por inserção, na qual o ponto de inserção é o gene 3 para o cromossomo do digestor e o ponto de remoção é o gene 7 deste mesmo cromossomo. O valor inserido é o alelo de valor 0 e foi removido o alelo de valor 1 da sequência que estava no ponto de remoção.

\begin{tabular}{|c|c|c|c|c|c|c|c|c|c|c|}
\hline \multicolumn{2}{|c|}{ Períodos } & \multicolumn{3}{|c|}{1} & \multicolumn{3}{|c|}{2} & \multicolumn{3}{|c|}{3} \\
\hline \multicolumn{2}{|c|}{ Micro-períodos } & 1 & 2 & 3 & 4 & 5 & 6 & 7 & 8 & 9 \\
\hline \multirow{2}{*}{ Antes } & Digestor & 2 & 3 & 4 & 1 & 0 & 2 & 1 & 1 & 3 \\
\cline { 2 - 12 } & PM1 & 1 & 2 & 5 & 4 & 3 & 5 & 3 & 4 & 5 \\
\hline \multirow{2}{*}{ Depois } & Digestor & 2 & 3 & 0 & 4 & 1 & 0 & 2 & 1 & 3 \\
\cline { 2 - 11 } & PM1 & 1 & 2 & 5 & 4 & 3 & 5 & 3 & 4 & 5 \\
\hline
\end{tabular}

Figura 47: Exemplo de mutação por inserção.

4. Mutação por rotação de cadeia

Esta mutação rotaciona todo o cromossomo à direita, como se o seu início fosse interligado ao seu final. A variação se encontra na quantidades de passos que são deslocados. Dado que um cromossomo tenha tamanho $R$, por exemplo, a mutação poderá gerar qualquer quantidade de passos entre 0 e $R-1$ para deslocar os genes deste cromossomo. Como ocorrido na mutação por inserção, a mutação por rotação de cadeia também é aplicada no máximo uma vez por cromossomo, pois gera grande perturbação no indivíduo. A Figura 48 ilustra um exemplo de mutação por rotação de cadeia para $R=1, R=2$ e $R=3$, para o cromossomo da máquina de papel 1 (PM1). Para facilitar a visualização da rotação, os genes inicial e final foram marcados em cinza escuro.

\begin{tabular}{|c|c|c|c|c|c|c|c|c|c|c|}
\hline \multicolumn{2}{|c|}{ Períodos } & \multicolumn{3}{|c|}{1} & \multicolumn{3}{|c|}{2} & \multicolumn{3}{|c|}{3} \\
\hline \multicolumn{2}{|c|}{ Micro-períodos } & 1 & 2 & 3 & 4 & 5 & 6 & 7 & 8 & 9 \\
\hline \multirow{2}{*}{ Antes } & Digestor & 2 & 3 & 4 & 1 & 0 & 2 & 1 & 1 & 3 \\
\cline { 2 - 12 } & PM1 & 1 & 2 & 5 & 4 & 3 & 5 & 3 & 4 & 5 \\
\hline \multirow{2}{*}{$\mathrm{R}=1$} & Digestor & 2 & 3 & 4 & 1 & 0 & 2 & 1 & 1 & 3 \\
\cline { 2 - 12 } & PM1 & 5 & 1 & 2 & 5 & 4 & 3 & 5 & 3 & 4 \\
\hline \multirow{2}{*}{$\mathrm{R}=2$} & Digestor & 2 & 3 & 4 & 1 & 0 & 2 & 1 & 1 & 3 \\
\cline { 2 - 11 } & PM1 & 4 & 5 & 1 & 2 & 5 & 4 & 3 & 5 & 3 \\
\hline \multirow{2}{*}{$\mathrm{R}=3$} & Digestor & 2 & 3 & 4 & 1 & 0 & 2 & 1 & 1 & 3 \\
\cline { 2 - 11 } & PM1 & 3 & 4 & 5 & 1 & 2 & 5 & 4 & 3 & 5 \\
\hline
\end{tabular}

Figura 48: Exemplo de mutação por rotação de cadeia com três passos.

5. Mutação de sequência

O operador de mutação por sequência tem como objetivo modificar as sequências 
dentro de um período completo (dia). Este operador guarda similaridades com a heurística de melhoria da sequência de produção, apresentada na Seção 4.1.2. Não existe, no entanto, uma verificação de custo de preparação de máquina durante a escolha das gramaturas. A nova sequência gerada em um período encolhido para sofrer mutação é determinada aleatoriamente. Por exemplo, na Figura 49, o período 2 foi escolhido para mutação. Este período originalmente tinha a sequência de produção $\{4,3,5\}$. Durante o processo de mutação, esta sequência foi aleatoriamente alterada para $\{4,5,3\}$. A partir do momento em que uma sequência é construída, ela será mantida, independente de melhoria ou não na qualidade de solução do indivíduo.

\begin{tabular}{|c|c|c|c|c|c|c|c|c|c|c|}
\hline \multicolumn{2}{|c|}{ Períodos } & \multicolumn{3}{|c|}{1} & \multicolumn{3}{|c|}{2} & \multicolumn{3}{|c|}{3} \\
\hline \multicolumn{2}{|c|}{ Micro-períodos } & 1 & 2 & 3 & 4 & 5 & 6 & 7 & 8 & 9 \\
\hline \multirow{2}{*}{ PM1 } & Antes & 1 & 2 & 5 & 4 & 3 & 5 & 3 & 4 & 5 \\
\cline { 2 - 11 } & Depois & 1 & 2 & 5 & 4 & 5 & 3 & 3 & 4 & 5 \\
\hline
\end{tabular}

Figura 49: Exemplo de mutação de sequência.

6. Mutação na quantidade de micro-períodos

A mutação na quantidade de micro-períodos tem o intuito de modificar o valor do super-gene, alterando a quantidade de micro-períodos considerados no momento da decodificação do indivíduo. Como cada indivíduo tem apenas um super-gene, esta mutação pode ser aplicada no máximo uma vez por indivíduo. Sempre que um indivíduo é escolhido para mutação, o valor de alelo do super-gene é aumentado em uma unidade. Isto só não é executado nos casos em que o alelo tem o maior valor possível. Neste caso, o alelo do super-gene é reduzido em uma unidade. Este aumento no alelo do super-gene foi privilegiado para contrapor a pressão gerada pelo operador de seleção sobre este gene, principalmente no início do processo evolutivo. Como uma sequência não evoluída gera altos custos de preparação de máquina, o operador de seleção tende a privilegiar indivíduos menores (que consideram menos micro-períodos) no início do processo evolutivo. Desta forma, a população tende a se compor inicialmente por indivíduo mais simples. A ideia é que estes indivíduos sofrem mutações durante sucessivas gerações e iterativamente aumentem de tamanho, a fim de gerar indivíduos mais complexos. A Figura 50 apresenta um exemplo de mutação no super-gene que ajusta a quantidade de micro-períodos. Neste exemplo, o super-gene tem valor inicial de 2 e após a mutação, passa a ter valor 3 . Observe que, com dois micro-períodos, o sequenciamento definido pelo indivíduo não está determinando a produção do item 5 em nenhum período do horizonte de planejamento. A partir do momento em que ocorre a mutação, ele passa a ser produzido 
em todos os períodos. Esta mudança gera um aumento no custo de preparação de máquina, que deve ser reduzido pelos demais custos para que este indivíduo possa ter uma boa função de aptidão e sobreviver na população.

\begin{tabular}{|c|c|c|c|c|c|c|c|c|c|c|c|c|c|}
\hline \multirow{2}{*}{\multicolumn{2}{|c|}{$\begin{array}{c}\text { Períodos } \\
\text { Micro-períodos }\end{array}$}} & \multicolumn{4}{|c|}{1} & \multicolumn{4}{|c|}{2} & \multicolumn{4}{|c|}{3} \\
\hline & & 1 & 2 & 3 & 4 & 5 & 6 & 7 & 8 & 9 & 10 & 11 & 12 \\
\hline DM1 & Antes & 1 & 2 & 5 & 2 & 4 & 3 & 5 & 2 & 3 & 4 & 5 & 2 \\
\hline PIVIT & Depois & 1 & 2 & 5 & 2 & 4 & 3 & 5 & 2 & 3 & 4 & 5 & 2 \\
\hline
\end{tabular}

Figura 50: Exemplo de mutação na quantidade de micro-períodos.

7. Mutação por campanha

A mutação por campanha primeiramente considera a sequência de produção, para então fazer a troca do alelo referente ao gene escolhido para sofrer mutação. Por campanha produtiva, é considerado um conjunto de micro-períodos onde uma máquina de papel produz apenas uma gramatura, ou seja, um conjunto contínuo de micro-períodos sem trocas na produção. No exemplo da Figura 51, por exemplo, temos que antes o cromossomo era composto por 7 campanhas de produção, produzindo os seguintes itens: 1, 2, 4, 5, 4, 3 e 5. Sendo que destas, apenas a segunda (produz o item 2) e terceira (produz o item 4) campanha são compostas por mais de um micro-período.

Esta mutação foi desenvolvida com o intuito de reduzir altos custos de preparação de máquina, reduzindo a quantidade de preparações de máquina do horizonte de planejamento. Quando um gene é selecionado para mutação, ele se encaixará em um dos seis casos a seguir:

- Caso 1: Se o gene $s$ escolhido para sofrer mutação é o primeiro gene do cromossomo $(s=1)$, então este gene receberá o mesmo alelo do segundo gene, ou seja, $x[1] \leftarrow x[2]$. Na Figura 51 a gramatura de índice 1 foi substituída pela gramatura de índice 2, reduzindo uma campanha de produção;

\begin{tabular}{|c|c|c|c|c|c|c|c|c|c|c|}
\hline \multicolumn{2}{|c|}{ Períodos } & \multicolumn{3}{|c|}{1} & \multicolumn{3}{c|}{2} & \multicolumn{3}{|c|}{3} \\
\hline \multicolumn{2}{|c|}{ Micro-períodos } & 1 & 2 & 3 & 4 & 5 & 6 & 7 & 8 & 9 \\
\hline \multirow{2}{*}{ PM1 } & Antes & 1 & 2 & 2 & 4 & 4 & 5 & 4 & 3 & 5 \\
\cline { 2 - 13 } & Depois & 2 & 2 & 2 & 4 & 4 & 5 & 4 & 3 & 5 \\
\hline
\end{tabular}

Figura 51: Exemplo do caso 1 da mutação por campanha.

- Caso 2: Se o gene $s$ escolhido para sofrer mutação é o último gene do cromossomo $(s=|S|)$, então este gene receberá o mesmo alelo do penúltimo gene, ou seja, $x[s] \leftarrow x[s-1]$. No exemplo da Figura 52, a gramatura de índice 5, que termina o sequenciamento da máquina PM1, é substituída pela gramatura de 
índice 3, reduzindo também em um a quantidade de campanhas de produção do horizonte de planejamento apresentado;

\begin{tabular}{|c|c|c|c|c|c|c|c|c|c|c|}
\hline \multicolumn{2}{|c|}{ Períodos } & \multicolumn{3}{|c|}{1} & \multicolumn{3}{|c|}{2} & \multicolumn{3}{|c|}{3} \\
\hline \multicolumn{2}{|c|}{ Micro-períodos } & 1 & 2 & 3 & 4 & 5 & 6 & 7 & 8 & 9 \\
\hline \multirow{2}{*}{ PM1 } & Antes & 1 & 2 & 2 & 4 & 4 & 5 & 4 & 3 & 5 \\
\cline { 2 - 12 } & Depois & 1 & 2 & 2 & 4 & 4 & 5 & 4 & 3 & 3 \\
\hline
\end{tabular}

Figura 52: Exemplo do caso 2 da mutação por campanha.

- Caso 3: Se o gene $s$ escolhido para sofrer mutação se encontra em um microperíodo no final de uma campanha de produção, então o gene $s$ é adicionado ao início da campanha seguinte. Um gene $s$ encerra uma campanha de produção quando $s$ tem alelo igual ao de $s-1(x[s]=x[s-1])$ e diferente de $s+1(x[s] \neq$ $x[s+1])$. Para adiciona-lo ao início da próxima campanha produtiva, devemos substituir seu valor pelo alelo do gene seguinte, ou seja, $x[s] \leftarrow x[s+1]$. A Figura 53 apresenta um exemplo no qual esta mutação troca um micro-período entre campanhas de produção da gramatura de índice 2 para a gramatura de índice 4;

\begin{tabular}{|c|c|c|c|c|c|c|c|c|c|c|}
\hline \multicolumn{2}{|c|}{ Períodos } & \multicolumn{3}{|c|}{1} & \multicolumn{3}{c|}{2} & \multicolumn{3}{|c|}{3} \\
\hline \multicolumn{2}{|c|}{ Micro-períodos } & 1 & 2 & 3 & 4 & 5 & 6 & 7 & 8 & 9 \\
\hline \multirow{2}{*}{ PM1 } & Antes & 1 & 2 & 2 & 4 & 4 & 5 & 4 & 3 & 5 \\
\cline { 2 - 12 } & Depois & 1 & 2 & 4 & 4 & 4 & 5 & 4 & 3 & 5 \\
\hline
\end{tabular}

Figura 53: Exemplo do caso 3 da mutação por campanha.

- Caso 4: Se o gene $s$ escolhido para sofrer mutação se encontra em um microperíodo no início de uma campanha de produção, então o gene $s$ é adicionado ao final da campanha anterior. No caso do gene que inicia uma campanha, ocorre o oposto do que foi descrito no caso 3. Aqui o gene $s$ tem valor igual ao seu sucessor $(x[s]=x[s+1])$ e diferente do seu antecessor $(x[s] \neq x[s-1])$. Para incorpora-lo a campanha de produção anterior, seu gene recebe alelo de valor igual ao do gene $s-1(x[s] \leftarrow x[s-1])$. A Figura 54 apresenta um exemplo no qual esta mutação troca um micro-período entre campanhas de produção da gramatura de índice 4 para a gramatura de índice 2;

\begin{tabular}{|c|c|c|c|c|c|c|c|c|c|c|}
\hline \multicolumn{2}{|c|}{ Períodos } & \multicolumn{3}{|c|}{1} & \multicolumn{3}{|c|}{2} & \multicolumn{3}{|c|}{3} \\
\hline \multicolumn{2}{|c|}{ Micro-períodos } & 1 & 2 & 3 & 4 & 5 & 6 & 7 & 8 & 9 \\
\hline \multirow{2}{*}{ PM1 } & Antes & 1 & 2 & 2 & 4 & 4 & 5 & 4 & 3 & 5 \\
\cline { 2 - 12 } & Depois & 1 & 2 & 2 & 2 & 4 & 5 & 4 & 3 & 5 \\
\hline
\end{tabular}

Figura 54: Exemplo do caso 4 da mutação por campanha. 
- Caso 5: Se o gene $s$ escolhido para sofrer mutação interrompe uma campanha de produção, ele receberá o alelo necessário para ligar as campanhas de mesma gramatura que o cercam. Um gene $s$ interrompe uma campanha produtiva quanto os alelos anterior $(s-1)$ e posterior $(s+1)$ a ele são iguais $(x[s-1]=$ $x[s+1])$ e seu alelo é diferente de ambos $(x[s] \neq x[s+1])$. Para adicionarmos este gene $s$ à campanha produtiva, modificamos seu alelo para o valor da gramatura produzida na campanha, ou seja, fazemos $x[s] \leftarrow x[s+1]$. A Figura 55 ilustra um exemplo no qual o alelo do micro-período 6 interrompe uma campanha da gramatura de índice 4. A mutação faz a troca deste alelo para 4, fazendo com que esta campanha estenda-se do micro-período 4 até o micro-período 7;

\begin{tabular}{|c|c|c|c|c|c|c|c|c|c|c|}
\hline \multicolumn{2}{|c|}{ Períodos } & \multicolumn{3}{|c|}{1} & \multicolumn{3}{c|}{2} & \multicolumn{3}{|c|}{3} \\
\hline \multicolumn{2}{|c|}{ Micro-períodos } & 1 & 2 & 3 & 4 & 5 & 6 & 7 & 8 & 9 \\
\hline \multirow{2}{*}{ PM1 } & Antes & 1 & 2 & 2 & 4 & 4 & 5 & 4 & 3 & 5 \\
\cline { 2 - 12 } & Depois & 1 & 2 & 2 & 4 & 4 & 4 & 4 & 3 & 5 \\
\hline
\end{tabular}

Figura 55: Exemplo do caso 5 da mutação por campanha.

- Caso 6: Se o gene $s$ escolhido para sofrer mutação tem alelo diferente, tanto do gene anterior $(s-1)$ como do gene posterior $(s+1)$, e estes genes também são diferentes entre si $(x[s-1] \neq x[s+1])$, então $s$ pode receber tanto o valor de $s-1(x[s] \leftarrow x[s-1])$ como o valor de $s+1(x[s] \leftarrow x[s+1])$, com $50 \%$ de chance para cada um. A Figura 56 apresenta um exemplo do sexto caso, onde o alelo do gene escolhido para mutação difere de seu antecessor e de seu sucessor. Neste caso, o alelo tem $50 \%$ de chance de ser trocado para 4 e $50 \%$ de chance de virar 5 .

\begin{tabular}{|c|c|c|c|c|c|c|c|c|c|c|}
\hline \multicolumn{2}{|c|}{ Períodos } & \multicolumn{3}{|c|}{1} & \multicolumn{3}{|c|}{2} & \multicolumn{3}{|c|}{3} \\
\hline \multicolumn{2}{|c|}{ Micro-períodos } & 1 & 2 & 3 & 4 & 5 & 6 & 7 & 8 & 9 \\
\hline \multirow{3}{*}{ PM1 } & Antes & 1 & 2 & 2 & 4 & 4 & 5 & 4 & 3 & 5 \\
\cline { 2 - 11 } & Depois (50\%) & 1 & 2 & 2 & 4 & 4 & 5 & 4 & 4 & 5 \\
\cline { 2 - 11 } & Depois (50\%) & 1 & 2 & 2 & 4 & 4 & 5 & 4 & 5 & 5 \\
\hline
\end{tabular}

Figura 56: Exemplo do caso 6 da mutação por campanha.

\subsubsection{Resumo das mutações}

A Tabela 11 apresenta um resumo das mutações desenvolvidas. Para cada mutação, são apresentadas três características importantes: frequência de aplicação, nível de distúrbio causado no indivíduo e se contém algum conhecimento específico do problema. A escolha aqui foi usar a frequência de aplicação para balancear o distúrbio causado pelas mutações, de tal forma que a frequência de aplicação seja inversamente proporcional ao 
distúrbio causado por uma mutação. O conhecimento específico do problema foi apresentado na tabela para deixar claro quais mutações são específicas do problema. A mutação na quantidade de micro-períodos pode ser vista como tendo conhecimento específico do problema, por estar incumbida de auxiliar em um ajuste de uma característica específica do problema.

Tabela 11: Resumo das mutações desenvolvidas.

\begin{tabular}{llll}
\hline Nome & $\begin{array}{l}\text { Frequência } \\
\text { de aplicaçãoo }\end{array}$ & $\begin{array}{l}\text { Distúrbio } \\
\text { causado }\end{array}$ & $\begin{array}{l}\text { Conhecimento } \\
\text { do problema }\end{array}$ \\
\hline Mutação simples & Alta & Baixo & Não \\
Mutação de troca & Alta & Baixo & Não \\
Mutação por inserção & Baixa & Alto & Não \\
Mutação por rotação de cadeia & Baixa & Alto & Não \\
Mutação de sequência & Média & Médio & Não \\
Mutação na quantidade de micro-períodos & Baixa & Alto & Sim \\
Mutação por campanha & Alta & Baixo & Sim \\
\hline
\end{tabular}

\subsection{Operador de seleção}

Foram considerados dois processos de seleção para o algoritmo genético proposto e, em ambos os casos, utilizamos o torneio de 2 como operador de seleção. O torneio de $k$ elementos consiste em escolher o melhor candidato a partir de $k$ indivíduos definidos aleatoriamente na população. O primeiro processo de seleção consiste em selecionar os indivíduos que sobreviverão para compor a população da geração seguinte e, portanto, foi denominado de seleção para sobrevivência. O segundo processo faz a seleção dos indivíduos que serão utilizados no processo de cruzamento para gerar novos indivíduos, denominado de seleção para cruzamento.

Na seleção para sobrevivência, o torneio de 2 seleciona o melhor dentre dois indivíduos, até que a quantidade de indivíduos requerida seja atingida. Não são aceitas múltiplas cópias de um mesmo indivíduo para a próxima geração, ou seja, um indivíduo é removido do grupo de possíveis escolhas aleatórias assim que entra no grupo de sobreviventes. Além disso, o melhor indivíduo da população sempre será copiado para a geração seguinte, sem que passe por um torneio. Nos casos onde todas as soluções da população são infactíveis, a melhor solução da população é definida como a solução com menor soma de infactibilidades (restrição (5.8)). No caso de soluções factíveis, a função objetivo original do problema é utilizada para verificar qual a melhor solução, ao invés de função de aptidão. 
Na seleção para cruzamento, são necessários dois torneios de 2 para cada processo de cruzamento. Cada um deles seleciona um dos pais que serão combinados para gerar dois novos indivíduos. Diferente do que ocorre na seleção para sobrevivência, a seleção para cruzamento não exige a remoção de indivíduos que já participaram do cruzamento, ou seja, um indivíduo poderá gerar mais de dois descentes. Isto depende da seleção aleatória deste indivíduo para participar dos torneios e da sua aptidão comparada aos seus oponentes do torneio. Os novos indivíduos são gerados até que a população da próxima geração esteja completa.

Este método híbrido foi implementado e aplicado para resolver o problema em estudo nesta tese. As análises computacionais e os resultados obtidos com exemplares de teste são apresentados no Capítulo 6. Neste mesmo capítulo, o desempenho do método híbrido é comparado com os valores obtidos pelas demais abordagens desenvolvidas, que são apresentadas no Capítulo 4. 


\section{Testes computacionais}

Este capítulo apresenta os testes computacionais realizados com as abordagens de solução desenvolvidas. Testes computacionais são importantes para verificar o desempenho de modelos matemáticos e métodos de solução. Com a geração de exemplares de teste a partir de dados reais e possíveis cenários, podemos avaliar de forma quantitativa quais as ferramentas de solução mais promissoras para aplicações e pesquisas futuras. Alguns métodos desenvolvidos têm características aleatórias, que devem ser consideradas durante os testes computacionais. Para os métodos que têm algum tipo de aleatoriedade, foram feitas 5 execuções por exemplar de teste. As análises principais são feitas utilizando os desvios relativos médios (gaps), tempos computacionais médios, gráficos de curvas de desempenho e testes de hipótese nula (teste de Wilcoxon com amostra pareada).

O capítulo de testes computacionais foi dividido da seguinte forma. A Seção 6.1 apresenta o processo de geração dos exemplares de teste, a forma como novas gramaturas foram introduzidas a partir dos dados existentes de uma indústria de papel e celulose e as características dos 540 exemplares gerados. A Seção 6.3 apresenta o processo de parametrização de cada método desenvolvido para a resolução do problema. Finalmente, os testes computacionais completos e as comparações entre as melhores variantes dos métodos propostos são apresentadas na Seção 6.4.

\subsection{Exemplares de teste gerados}

O gerador de exemplares utilizado foi construído com base no gerador de Figueira et al. (2013) para o problema com uma máquina de papel. Ao gerador de base, foi adicionado a possibilidade de gerar exemplares de teste com múltiplas máquinas de papel, além da remoção da consideração de celulose reciclada na mistura e modificação das gramaturas 
consideradas com inserção de novas gramaturas. Foram utilizadas diversas gramaturas inferiores as definidas no gerador base, de forma a adequar os exemplares gerados aos tipos de papéis produzidos nas empresas visitadas durante o trabalho.

Para estas novas gramaturas geradas, não existem dados quanto aos tempos e custos de preparações de máquinas, assim, estes foram gerados por meio de funções de interpolação com os dados existentes da indústria portuguesa (SANTOS; ALMADA-LOBO, 2012). O processo de extrapolação utilizado consiste em gerar um gráfico de dispersão com o valor do tempo/perda de preparação de máquina em relação a variação na gramatura. Por exemplo, se consideramos a troca de uma gramatura 115 para uma gramatura 140, com tempo de preparação de máquina de 10 minutos, adicionamos o ponto $(140-115=25,10)$ no gráfico. Com o intuito de gerar instancias de apenas uma família, foram consideradas apenas as gramaturas da família com maior variedade de gramaturas. Apenas estas gramaturas foram consideradas para evitar que os custos ou tempos de preparação de máquinas relativos a troca entre famílias de produtos distintos fossem contabilizados e influenciassem nos valores calculados.

Foram testadas três formas distintas de linhas de tendências para aproximar o comportamento dos pontos, sendo elas: lineares, polinomiais e logarítmicas. As retas lineares por partes foram as que melhor se aproximaram pelo método de quadrados mínimos. As Figuras 57 e 58 apresentam as retas que foram geradas a partir dos dados existentes. Os dados foram divididos em seis faixas de valores, e cada faixa foi associada a uma reta diferente. Estas retas foram utilizadas para gerar os dados aproximados para qualquer variação de gramatura dentro dos limites da interpolação. Como pode ser visto, ambos os gráficos são simétricos a partir do ponto zero do eixo das abscissas, o que reduz a análise a metade dos dados e apenas três funções nas quais utilizam-se diferença modular na troca de gramaturas. Isto se deve ao fato de que ambas matrizes de dados são simétricas, ou seja, a troca de uma gramatura A para outra B gasta o mesmo tempo que a troca de B para A.

Durante a construção dos conjuntos das gramaturas foram utilizadas as equações da Tabela 12 para gerar os tempos e perdas de preparação de máquina. Nestas equações, $|X|$ representa o valor absoluto (norma) da diferença de gramaturas. A partir destas funções foi possível definir uma nova faixa de gramaturas para os exemplares gerados.

Foram gerados exemplares com 8, 16 e 24 gramaturas, que variam entre $45 \mathrm{~g} / \mathrm{m}^{2}$ e $240 \mathrm{~g} / \mathrm{m}^{2}$. Neste caso, a variação máxima entre gramaturas é de $195 \mathrm{~g} / \mathrm{m}^{2}$, o que é bem próximo dos $185 \mathrm{~g} / \mathrm{m}^{2}$ encontrados nos dados originais. Isto faz com que a maior parte 


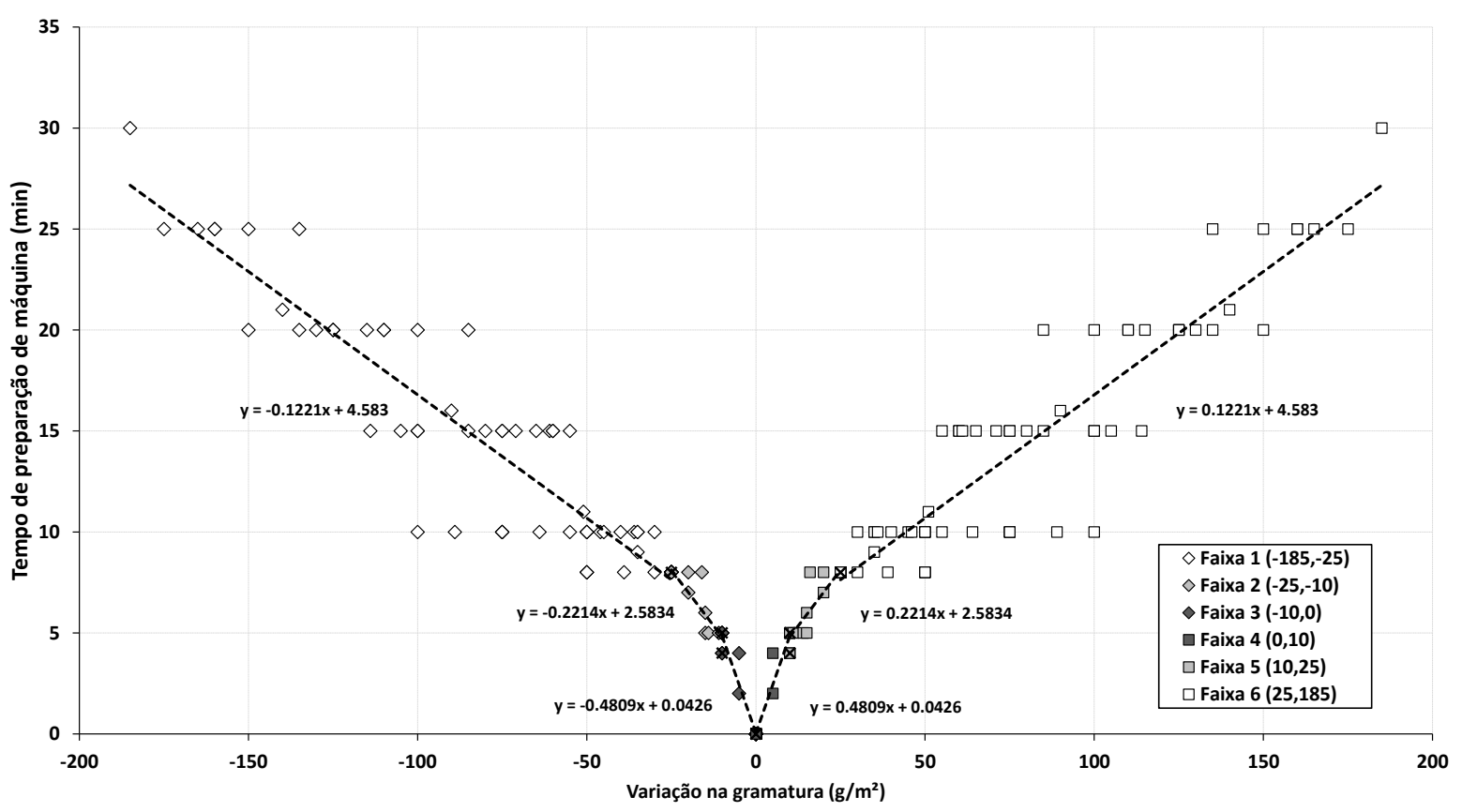

Figura 57: Extrapolação dos tempos de preparação de máquina.

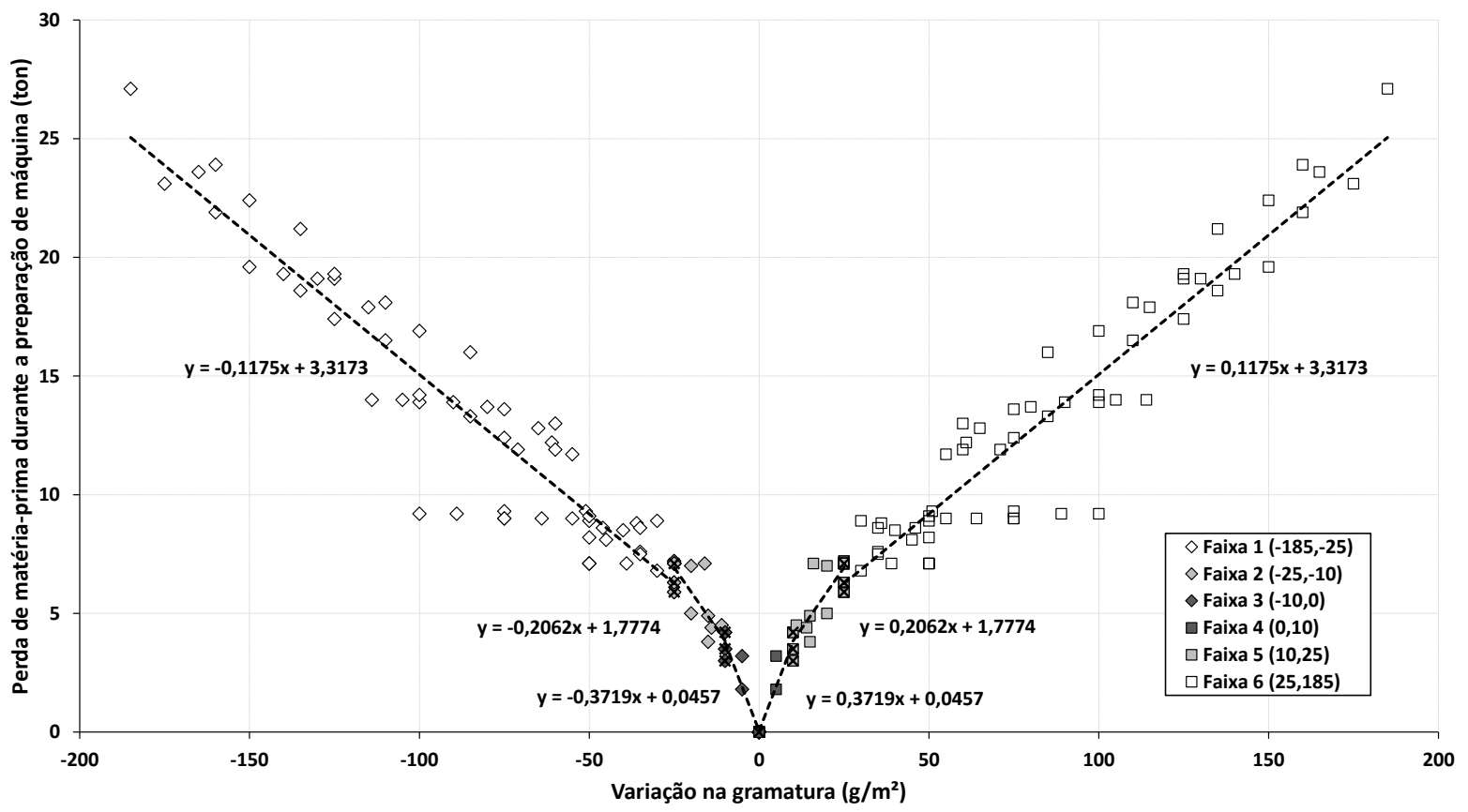

Figura 58: Extrapolação das perdas durante a preparação de máquina.

dos dados gerados estejam dentro da região de interpolação, onde os dados podem ser definidos com menor taxa de erros.

Quatro fatores de controle das características dos exemplares gerados foram utilizados, sendo eles: carga de trabalho das máquinas de papel, carga de trabalho do digestor, nível de uso da linha de recuperação química e carga de uso dos estoques intermediários. 
Tabela 12: Funções para calculo de perdas e tempos de preparação de máquina.

\begin{tabular}{ccc}
\hline Variação da gramatura $(|\mathrm{X}|)$ & Tempo de preparação & Perda na preparação \\
\hline $0-10$ & $Y=0,4809 \cdot|X|+0,0426$ & $Y=0,3719 \cdot|X|+0,0457$ \\
$11-20$ & $Y=0,2214 \cdot|X|+2,5834$ & $Y=0,2062 \cdot|X|+1,7774$ \\
$21-\infty$ & $Y=0,1221 \cdot|X|+4,5830$ & $Y=0,1175 \cdot|X|+3,3173$ \\
\hline
\end{tabular}

Os dois primeiros fatores funcionam de forma similar e são definidos por meio de um valor real que indica qual a porcentagem necessária de uso do digestor e das máquinas de papel para atender as respectivas demandas. Por exemplo, um valor de 1,2 para a carga de trabalho das máquinas de papel indica que cerca de $120 \%$ do tempo das máquinas de papel no horizonte de planejamento seria utilizado para produzir e atender demanda/atrasos. Neste caso, a capacidade não é suficiente para atender toda a demanda e existirão atrasos superiores a $20 \%$ no final do horizonte de planejamento. No caso do digestor, a demanda por celulose virgem é definida a partir das taxas de consumo e das quantidades demandadas por cada gramatura, além de um cálculo de perda estimada com preparação de máquina. O fator de produção $\alpha$, fator de produção de celulose utilizado no modelo matemático (Seção 3.4), é calculado a fim de gerar a carga de trabalho de acordo com os parâmetros do exemplar que será gerado. Como todas as demais características do processo produtivo dependem da taxa de produção de celulose, os demais fatores são definidos de acordo com esta taxa de produção. Entre estes fatores estão: demanda, taxa de produção de papel, taxas de consumo da linha de recuperação química, entre outros.

Os níveis de uso da linha de recuperação química e dos estoques intermediários têm a definição oposta ao apresentado para os dois primeiros fatores. Quanto maior o valor destes fatores, maior a folga de trabalho da unidade. Este calculo é feito por meio da variação do parâmetro $\alpha$ com relação a $\alpha^{0}$ e o fator que está sendo ajustado. O parâmetro $\alpha^{0}$ indica o valor de $\alpha$ original, definido no estudo de caso de Santos e Almada-Lobo (2012) e utilizado como base para os exemplares gerados. Por exemplo, se houve um aumento de $20 \%$ no parâmetro $\alpha\left(\alpha=1,2 \cdot \alpha^{0}\right)$ e for escolhido nível de uso de estoques intermediários igual a $80 \%$, temos que o limite máximo dos estoques são multiplicados por $1,2 * 0,8=0,96$, ou seja, os limites dos estoques intermediários terão $96 \%$ do tamanho original. Por outro lado, se o nível de estoque for ajustado para 120\%, os estoques aumentarão em $44 \%$ e será gerado um exemplar com estoques intermediários mais folgados do que a anterior.

A combinação destes fatores foi definida em uma série de cenários, para facilitar o agrupamento e auxiliar as análises dos resultados computacionais. As combinações 
utilizadas durante a geração dos dados são apresentadas na Tabela 13. Os quatro recursos considerados na geração dos cenários de cada exemplar foram: carga de trabalho das máquinas de papel (cargaMP), carga de trabalho do digestor (cargaDig), folga de trabalho da linha de recuperação química (folgaRC) e folga de trabalho dos tanques de estoque intermediário (folgaEst). Para cada recurso, foram definidos quatro níveis de carga de trabalho, denominados Folgado (F), Normal (N), Apertado (A) e Muito Apertado (MA). Os valores de cada recurso que definem estas denominações são apresentados na Tabela 14.

Tabela 13: Cenários utilizados para a geração de exemplares de teste.

\begin{tabular}{ccccc}
\hline Nome do padrão & cargaMP & cargaDig & folgaRC & folgaEst \\
\hline P01 & N & N & N & N \\
P02 & F & N & N & N \\
P03 & A & N & N & N \\
P04 & MA & N & N & N \\
P05 & N & F & N & N \\
P06 & N & A & N & N \\
P07 & N & MA & N & N \\
P08 & N & N & F & N \\
P09 & N & N & A & N \\
P10 & N & N & MA & N \\
P11 & N & N & N & F \\
P12 & N & N & N & A \\
P13 & N & N & N & MA \\
P14 & A & N & A & N \\
P15 & A & N & A & A \\
\hline
\end{tabular}

Tabela 14: Valores em porcentagem (\%) correspondentes a cada nível de carga por recurso.

\begin{tabular}{ccccc}
\hline Nome do padrão & Folgado & Normal & Apertado & Muito Apertado \\
\hline cargaMP & 80 & 100 & 110 & 120 \\
cargaDig & 80 & 100 & 110 & 120 \\
folgaRC & 105 & 100 & 95 & 90 \\
folgaEst & 120 & 100 & 85 & 70 \\
\hline
\end{tabular}

Foram gerados exemplares de teste com as seguintes características:

- Máquinas de papel: Uma e duas máquinas paralelas

- Gramaturas: 8, 16 e 24 gramaturas distintas 
- Horizonte de planejamento (dias): 7, 15 e 30 dias

- Micro-períodos: 3 e 4

- Padrões: 15 diferentes padrões (ver Tabela 13)

Foi gerado um exemplar para cada combinação destas cinco características. A quantidade de combinações de todas estas características resultou em um total de 540 exemplares de teste. Quando agrupados pelas quatro primeiras características, estes 540 exemplares são aglutinadas em 36 grupos de testes.

Os custos associados a cada parcela da função objetivo (3.74) foram gerados a partir dos preços de cada gramatura. As fórmulas de calculo destes são apresentadas na Seção 3.5.1, pois também são utilizadas na construção dos exemplares de testes preliminares do modelo matemático. Resumidamente, foram utilizados os seguintes valores para cada parcela da função objetivo:

- Custo de estoque: $h_{j t}^{+}=\frac{25 \% \cdot p r i c e_{j}}{365}$

- Custo de atraso: $h_{j t}^{-}=10 \cdot h_{j t}^{+}$

- Custo de preparação de máquina: $s c_{k j m}=\operatorname{price}_{j} \cdot \frac{s l_{k j m}}{5}$

- Incentivo a produção de vapor: $\gamma=0.1$

- Penalização por trocas na velocidade do digestor: $\varepsilon=0.01$

\subsection{Parametrização do Cplex}

Nas versões mais recentes, o Cplex conta com uma função de parametrização automático que considera uma hierárquia própria de parâmetros. Esta parametrização automática do método é feita com o auxílio de um ou mais exemplares de teste. Este procedimento foi testado aqui como possível parametrizador para o Cplex, no entanto, nos testes preliminares com este procedimento não foi encontrado nenhum conjunto de parâmetros mais eficiente que o conjunto padrão, de acordo com a métrica da função de ajuste automático. A dificuldade encontrada no seu uso se apresentou devido a forma como o Cplex diferencia a eficiência dos conjuntos de parâmetros. A única métrica utilizada é o tempo computacional. Como nenhum dos conjuntos testados consegue resolver o problema até a otimalidade, todos os testes foram excerrados por exceder o tempo limite. 
Isto gerou valores iguais da métrica para todos os conjuntos de parâmetros, fazendo com que os valores padrões fossem mantidos. Foram feitos também testes com condição de parada definida a partir de um gap aceitável e que pudesse ser atingido dentro do tempo limite pelas melhores parametrizações. No entanto, os resultados obtidos com o processo de ajuste automático de parâmetros foi o mesmo. Por estes motivos, optou-se nesta tese por utilizar uma metodologia própria de parametrização.

Durante o ajuste de parâmetros do Cplex versão 12.6, foram utilizados 10 exemplares escolhidas aleatoriamente dentre os 540 existentes. Foram escolhidos 13 parâmetros para serem ajustados, sendo eles: uso do pré-solver, método de solução LP utilizado para resolver o nó raiz, limite de cortes, intensidade da quebra de simetria, ênfase usada no processo de busca dentro da árvore de solução do MIP, método de solução LP usado nos demais nós, estratégia de seleção de nós, direção de ramificação, estratégia de busca em profundidade usada, estratégia de seleção de variáveis para a ramificação, nível de probing, uso da heurística local branching e frequência de aplicação das heurísticas.

Como a combinação de todos os valores para os 13 parâmetros seria computacionalmente inviável, os ajustes de parâmetros foram feitos de forma iterativa, considerando a ordem dos 13 parâmetros descritos e fixando a melhor opção de cada parâmetro. Como o Cplex é um método de solução exata, executou-se apenas uma cada valor de parâmetro para cada exemplar de teste utilizado.

Inicialmente, na primeira iteração, foram executados os 10 testes com os 13 parâmetros nos valores do Cplex padrão. Na iteração seguinte, desligou-se o pré-solver e os demais parâmetros foram mantidos fixos nos seus valores padrões. Ajustado o primeiro parâmetro, escolhido entre ligado e desligado, passamos ao seguinte (método de solução LP utilizado para resolver o nó raiz), onde todas as opções de valores foram testadas e apenas a melhor foi fixada para as iterações seguintes. O processo continua iterativamente até que os 13 parâmetros sejam ajustados. Durante o ajuste dos parâmetros do Cplex, os testes tiveram o tempo limitado em 600 segundos.

Como resultado da parametrização, foram feitas mudanças em 4 dos 13 parâmetros considerados. A estratégia de seleção de variáveis foi modificada para strong branching (do valor padrão 0 para 3), que é indicado como vantajoso para problemas de grande porte e complicados. O nível de probing foi modificado para muito agressivo (do valor padrão 0 para 3). A ênfase na busca do MIP foi alterada para buscar soluções escondidas (do valor padrão 0 para 4) e a quebra de simetria foi desligada (do valor padrão -1 para $0)$. 
Após o ajuste de parâmetros, todos os 540 exemplares foram resolvidos com o Cplex já com a parametrização e a versão padrão, a fim de comparar os resultados e analisar as melhorias obtidas. Apresentamos a seguir os gráficos de curvas de desempenho utilizados para comparar as duas parametrizações.

O gráfico de curvas de desempenho de Dolan e Moré (2002) (DM) visa comparar dois ou mais métodos de solução de acordo com tempo ou qualidade de solução. Para métodos exatos, ele pode ser utilizado para comparar os tempos utilizados por cada método para provar a otimalidade dos problemas resolvidos. No caso de métodos heurísticos, ele é particularmente usado para comparar a qualidade de solução entre métodos com tempo de solução similares ou limitados a um mesmo valor. A comparação é feita com a resolução de um conjunto fixo de exemplares para um ou mais métodos de solução.

O gráfico de Dolan e Moré (2002) funciona da seguinte forma. Para cada exemplar, define-se a solução com menor valor (para problemas de minimização) e faz-se a divisão da solução de cada método por este valor mínimo. Isto dará como resultado uma medida denominada $\tau$, que indica a proporção entre a solução de cada método e a melhor solução obtida por todos os métodos. Esta medida é uma espécie de desvio relativo da solução do método avaliado com relação a melhor encontrada. Considere que serão avaliados $p$ métodos e $s$ exemplares, e que $r_{p s}$ indica a relação entre a solução de $p$ no exemplar $s$ e a melhor solução deste exemplar $\left(r_{p s}=\frac{f_{p s}}{\min \left\{f_{p s} \mid \forall p\right\}}\right)$. O gráfico de desempenho indicará qual a porcentagem de exemplares de $s$ nas quais o método $p$ obteve resultado $r_{p s} \leq \tau$, para cada valor de $\tau$ definido no eixo das abscissas. O valor de porcentagem $\operatorname{com} \tau=1$ indica a quantidade de melhores soluções obtidas pelo método. Além disso, o momento em que um método atinge o limite de $100 \%$ indica que este método não teve nenhum resultado pior do que o $\tau$ correspondente.

Como pode ser verificado no gráfico da Figura 59, o Cplex com parâmetros alterados (CPX Parametrizado) obteve resultados superiores aos obtidos pela versão padrão. Isto ocorreu tanto na quantidade de melhores soluções $(\tau=1)$ como para restante do gráfico, visto que a sua curva de desempenho está sempre mais próxima de $100 \%$. Isso significa que foi possível encontrar soluções inteiras factíveis de melhor qualidade a partir da parametrização adequada do Cplex.

A Figura 60 apresenta a porcentagem acumulada de exemplares de teste pelo desvio percentual obtido neste método exato. O desvio percentual de um exemplar, mais conhecido pelo termo em inglês gap, representa a diferença relativa entre os limitantes superior e inferior obtidos pelo método de solução durante a resolução de um exemplar de teste do 


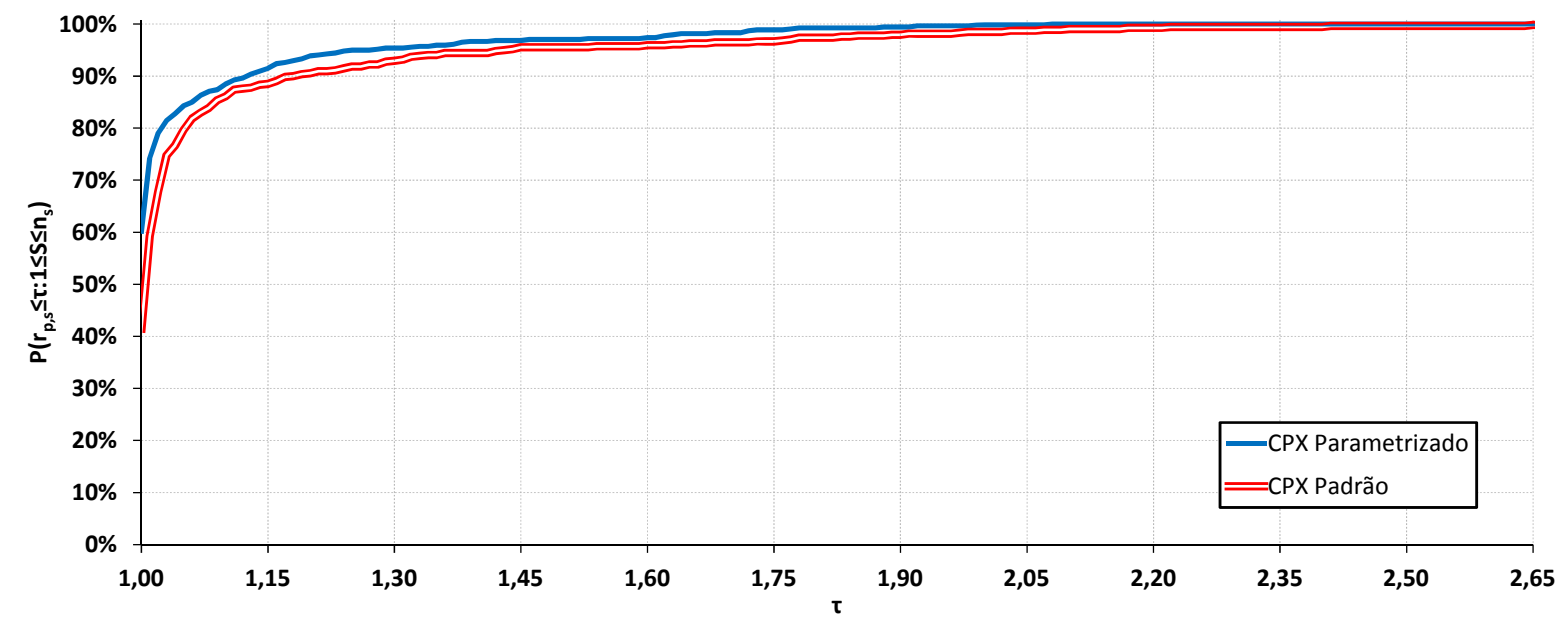

Figura 59: Gráfico de curvas de desempenho do Cplex padrão contra o Cplex com parâmetros ajustados (somente soluções inteiras).

problema. O cálculo do desvio é obtido da seguinte fórmula:

$$
\operatorname{Gap}(x)=\frac{f(x)-L B}{f(x)} \cdot 100
$$

no qual $f(x)$ representa o valor da função objetivo da solução encontrada e $L B$ é o maior limite inferior retornado por todas as variações executadas do Cplex após uma hora de execução, sendo elas: o Cplex padrão, o Cplex parametrizado e o Cplex com solução inicial das heurísticas construtivas HCG e HCBC.

A curva de desempenho da Figura 60 representa a porcentagem de exemplares em que cada variante do Cplex obteve desvio percentual inferior ao estipulado no eixo das abscissas. Por exemplo, o Cplex parametrizado obteve um desvio percentual igual ou inferior a $20 \%$ em quase $50 \%$ dos 540 exemplares. Nestas curvas podemos ver um desempenho similar entre as duas variantes do Cplex, sendo que cada uma é melhor em parte do gráfico e nenhuma domina a outra completamente. Como a versão parametrizada obteve melhores soluções inteiras, a explicação para um desempenho percentual tão parecido é que a parametrização de alguma forma deteriorou o limitante inferior, seja modificando a ênfase de busca do MIP ou os demais parâmetros.

Considerando estes resultados, utilizar-se-á no decorrer das análises dos testes computacionais as soluções inteiras obtidas pelo Cplex parametrizado, enquanto o limitante inferior utilizado nas análises será o melhor limitante encontrado pelas duas variantes. O mesmo limitante foi utilizado nos cálculos dos desvios de todos os métodos para compa- 


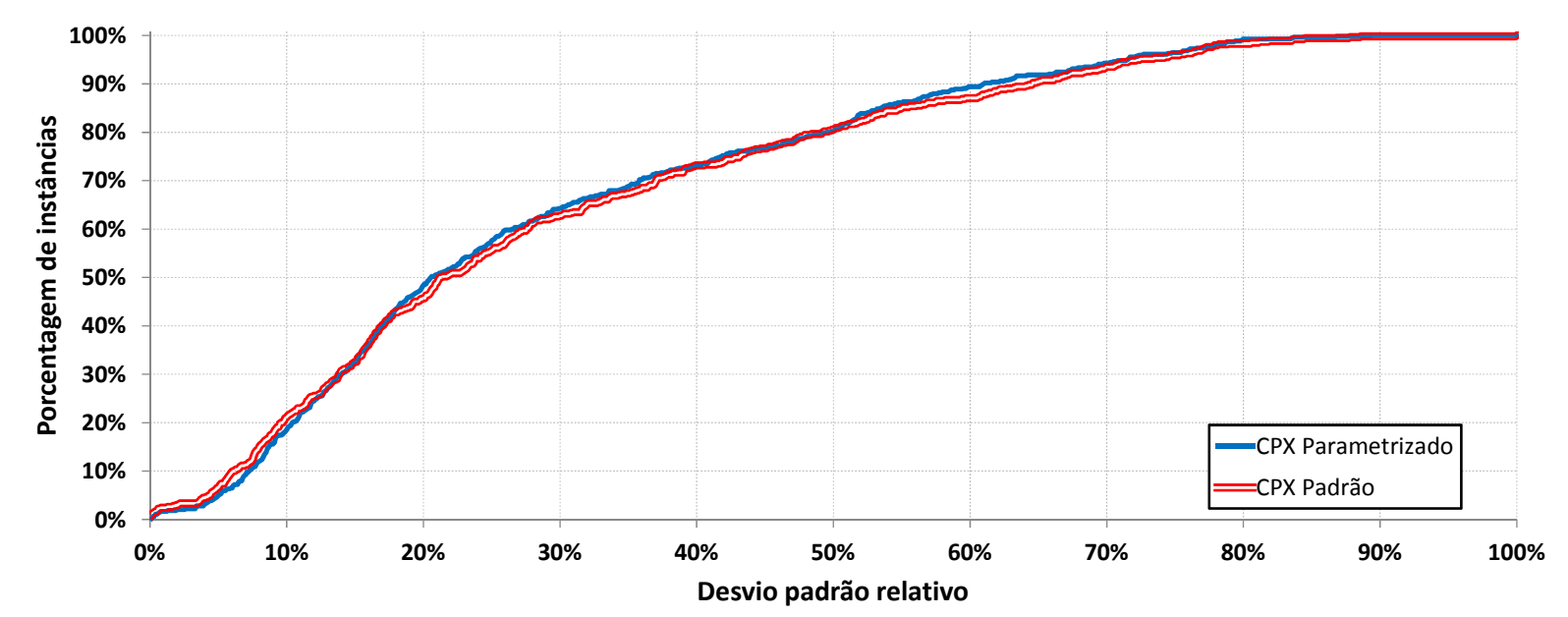

Figura 60: Gráfico de curva de desempenho do Cplex padrão contra o Cplex com parâmetros ajustados $($ gap $)$.

rações mais justas. Ademais, o uso do melhor limitante inferior possibilita uma medida mais adequada da distância em que as soluções de cada método podem estar em relação as soluções ótimas.

\subsection{Parametrização dos métodos desenvolvidos}

A parametrização de cada método foi desenvolvida de acordo com as suas características de funcionamento. Houve métodos nos quais todos os 540 exemplares de teste foram considerados durante a parametrização, como é o caso da heurística construtiva gulosa apresentada na Seção 4.1. Como a heurística gera soluções factíveis na média em pouco menos de 1 segundo, testar um conjunto de possíveis parâmetros para esta heurística construtiva considerando todos os exemplares não se torna proibitivo devido ao tempo computacional. Por outro lado, a heurística relaxe-e-fixe, mais complexa, teria um tempo proibitivo se forem considerados todos os exemplares na parametrização.

Para estes métodos que demandam mais tempo, como a relaxe-e-fixe e a fixe-e-otimize, foi aleatoriamente definido um sub-conjunto de 18 exemplares como conjunto de ajuste de parâmetros. Cada um destes 18 exemplares foi escolhido a partir de um tamanho de problema, que consiste em uma combinação de quantidade de máquinas de papel, gramaturas e períodos. No caso dos micro-períodos, foram consideradas apenas os exemplares com tamanho 4. Por exemplo, temos 15 exemplares com 1 máquina de papel $(M=1)$, 8 gramaturas $(K=8), 7$ períodos de planejamento $(T=7)$ e 4 micro-períodos $(S=4)$, sendo que cada um destes tem um dos padrões de carga indicados na Tabela 13. Destes 15 
exemplares, apenas um foi sorteado aleatoriamente para fazer parte do grupo de parametrização. Como geramos 36 grupos de teste e selecionamos apenas os grupos com número de micro-períodos igual a 4, temos apenas 18 exemplares selecionados para a parametrização. Esperamos que desta forma seja possível ter um sub-conjunto que seja razoavelmente representativo do conjunto de exemplares gerados. Mesmo para as abordagens de solução que incluem aleatoriedade, foi considerada apenas uma execução para cada exemplar de teste por abordagem e conjunto de parâmetros no processo de parametrização.

Apresentamos a seguir o processo utilizado para a parametrização de cada método e o conjunto de parâmetros escolhidos para a comparação final. Os desvios percentuais das análises referentes a parametrização dos métodos foram obtidos utilizando o melhor limitante inferior encontrado após uma hora de execução do modelo matemático com a ferramenta Cplex 12.6 .

\subsubsection{Heurística construtiva gulosa}

A heurística construtiva gulosa tem execução rápida, com média de aproximadamente 0.29 segundos para cada exemplar. Este tempo reduzido de execução auxiliou o ajuste do único parâmetro considerando todos os 540 exemplares de teste. O parâmetro $\alpha$ define qual a demanda mínima necessária para que um item possa ser alocado a um microperíodo (Linha 7 do Algoritmo 4.1). Para ser mais preciso, ele define a proporção do micro-período que será ocupada pela demanda existente. Quanto menor o valor de $\alpha$, menor a demanda necessária para que um micro-período esteja apto a ser alocado. No caso de $\alpha=0$, por exemplo, uma demanda positiva de uma gramatura $j$ é suficiente para alocar a produção de $j$ no micro-período e máquina.

A Tabela 15 apresenta os desvios padrões mínimo, médio e máximo, e o tempo computacional médio para cada valor de $\alpha$ testado para todos os exemplares. Foram testados valores de 0 até 1 com passo de 0,1. Em geral, os resultados obtidos são bem similares e variam no máximo $1,44 \%$ no valor médio de desvio percentual. O tempo foi ainda mais similar, com média variando de 0,28 à 0,31 segundo. Os quatro melhores resultados médio, que se encontram no intervalo de $\alpha$ variando de 0 à 0,3 , foram escolhidos para uma análise foi utilizado um gráfico de curvas de desempenho.

A Figura 61 apresenta o gráfico com as curvas de desempenho (DM) dos quatro melhores ajustes de $\alpha(0$ à 0,3$)$. P0 indica a curva de desempenho com $\alpha=0, \mathrm{P} 1$ se refere ao desempenho de $\alpha=0,1$ e assim por diante. 
Tabela 15: Desvio percentual das soluções da heurística gulosa.

\begin{tabular}{ccccc}
\hline$\alpha$ & Mínimo(\%) & Médio(\%) & Máximo(\%) & Tempo médio (s) \\
\hline 0,0 & 11,76 & 32,20 & 69,34 & 0,28 \\
0,1 & 10,11 & 32,04 & 73,23 & 0,31 \\
0,2 & 11,80 & $\mathbf{3 1 , 8 1}$ & $\mathbf{6 9 , 0 1}$ & 0,28 \\
0,3 & 11,79 & 32,14 & 71,93 & 0,28 \\
0,4 & 11,65 & 32,74 & 73,20 & 0,28 \\
0,5 & 11,21 & 32,96 & 73,07 & 0,28 \\
0,6 & 10,81 & 33,13 & 73,60 & 0,30 \\
0,7 & 10,77 & 33,25 & 74,83 & 0,30 \\
0,8 & 10,64 & 32,86 & 76,10 & 0,30 \\
0,9 & 10,12 & 32,60 & 72,72 & 0,30 \\
1,0 & $\mathbf{9 , 7 6}$ & 32,26 & 74,52 & 0,30 \\
\hline Total geral & 9,76 & 32,54 & 76,10 & 0,29 \\
\hline
\end{tabular}

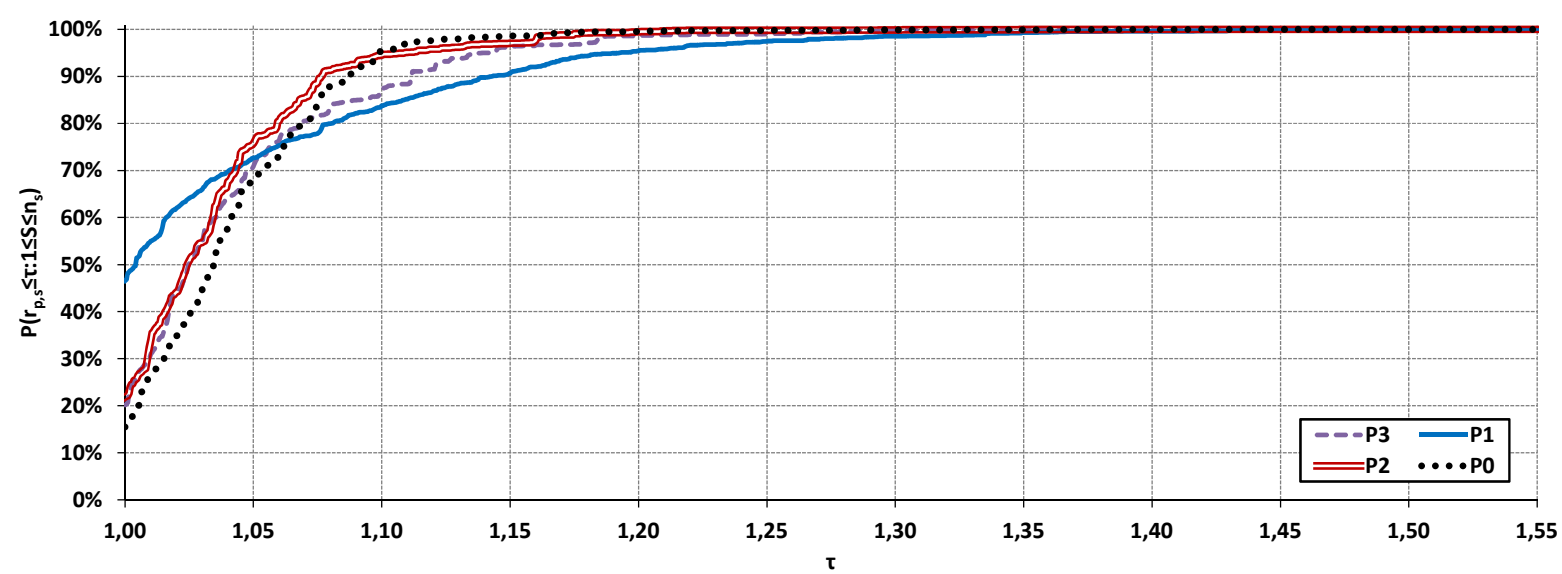

Figura 61: Gráfico de curvas de desempenho dos quatro melhores conjuntos de parâmetros da heurística gulosa.

Podemos verificar neste gráfico que a heurística P1 tem uma quantidade de melhores soluções superior às demais curvas, encontrando a melhor solução em quase metade dos casos. É importante ressaltar que a soma das quantidades de melhores soluções pode ser superior a $100 \%$, pois dois ou mais métodos podem encontrar uma mesma solução, contabilizada para ambos os métodos. A partir de $\tau=1,043$, a variante P2 se mostra superior, ou seja, ela tem uma porcentagem maior de resultados com no máximo 4,3\% de piora com relação as soluções mínimas encontradas. A partir de $\tau=1,064$ ou $6,4 \%$, temos que P1 passa a ser o pior método. Mesmo não sendo a melhor variação de $\alpha$ para $\tau>1,05$, P1 obteve mais do que o dobro de melhores soluções $(\tau=0)$ em relação às demais variantes. Por este motivo, o valor escolhido para $\alpha$ nesta heurística foi $\alpha=0,1$. 


\subsubsection{Heurística construtiva baseada em ciclos predefinidos de produção}

O processo de ajuste de parâmetros da heurística construtiva baseada em ciclos foi idêntico ao processo aplicado para a heurística construtiva gulosa. Como apenas o parâmetro $\alpha$ deve ser ajustado e a heurística apresenta tempo computacional reduzido, utilizou-se o conjunto completo de 540 exemplares para fazer a parametrização.

A Tabela 16 apresenta os desvios percentuais médios considerando cada conjunto de testes. No caso de $\alpha=0,8$ temos um desvio máximo de $100 \%$, o que indica que houve pelo menos um exemplar no qual a heurística não foi capaz de obter uma solução factível. No caso destes testes, foi apenas um exemplar de teste sem solução dentre os 540 testes realizados. Por este motivo, o parâmetro $\alpha=0,8$ não foi considerado dentre os quatro melhores ajustes no gráfico da Figura 62. Os quatro parâmetros de melhor média após $\alpha=0,8$ foram os valores $0,1,0,7,0,9$ e 1,0. A diferença máxima do desvio médio destes parâmetros é igual a 0,36\%, ou seja, o desempenho das variantes é mais similar do que o caso anterior.

Tabela 16: Desvio percentual das soluções da heurística baseada em ciclos.

\begin{tabular}{ccccc}
\hline$\alpha$ & Mínimo(\%) & Médio(\%) & Máximo(\%) & Tempo médio (s) \\
\hline 0,0 & 11,05 & 34,12 & 63,56 & 2,07 \\
0,1 & $\mathbf{7 , 5 2}$ & 29,13 & 69,72 & 1,16 \\
0,2 & 10,77 & 33,19 & 61,21 & 2,06 \\
0,3 & 10,24 & 32,06 & 60,37 & 2,06 \\
0,4 & 8,54 & 30,87 & $\mathbf{5 9 , 1 4}$ & 2,05 \\
0,5 & 9,40 & 30,07 & 63,89 & 2,05 \\
0,6 & 9,35 & 29,50 & 60,54 & 2,06 \\
0,7 & 8,86 & 28,81 & 60,94 & 2,05 \\
0,8 & 10,14 & $\mathbf{2 8 , 5 7}$ & 100,00 & 2,06 \\
0,9 & 10,14 & 28,77 & 65,77 & 1,16 \\
1,0 & 7,62 & 29,11 & 68,64 & 1,16 \\
\hline Total geral & 7,52 & 30,38 & 100,00 & 1,81 \\
\hline
\end{tabular}

A Figura 62 apresenta as curvas de desempenho (DM) das quatro melhores variantes do parâmetro $\alpha$ que não tiveram problemas de factibilidade. Podemos verificar neste gráfico que as curvas estão bem próximas e que a variante $\mathrm{P} 7(\alpha=0,7)$ domina uma parte intermediaria do gráfico, enquanto que a variante P9 $(\alpha=0,9)$ domina a partir de $\tau \geq 1,09$. Novamente a variante que teve maior quantidade de melhores soluções foi P1 $(\alpha=0,1)$. Devido a pequena diferença com a variante de melhor média e por ter obtido mais melhores soluções, a variante P1 foi selecionada como melhor parâmetro para 
este método. O valor de $\alpha=0,1$ pode ser relacionado com a diferença entre os custos de estoque e atraso utilizados dos exemplares testados. O custo de atraso na entrega de uma tonelada da gramatura $j$ foi considerado igual a 10 vezes o custo de estoque de uma tonelada desta mesma gramatura (Seção 6.1). Portanto, exigir que ao menos $10 \%$ do período $(\alpha=0,1)$ seja usado para atender demanda parece razoavelmente alinhado com esta relação dos custos.

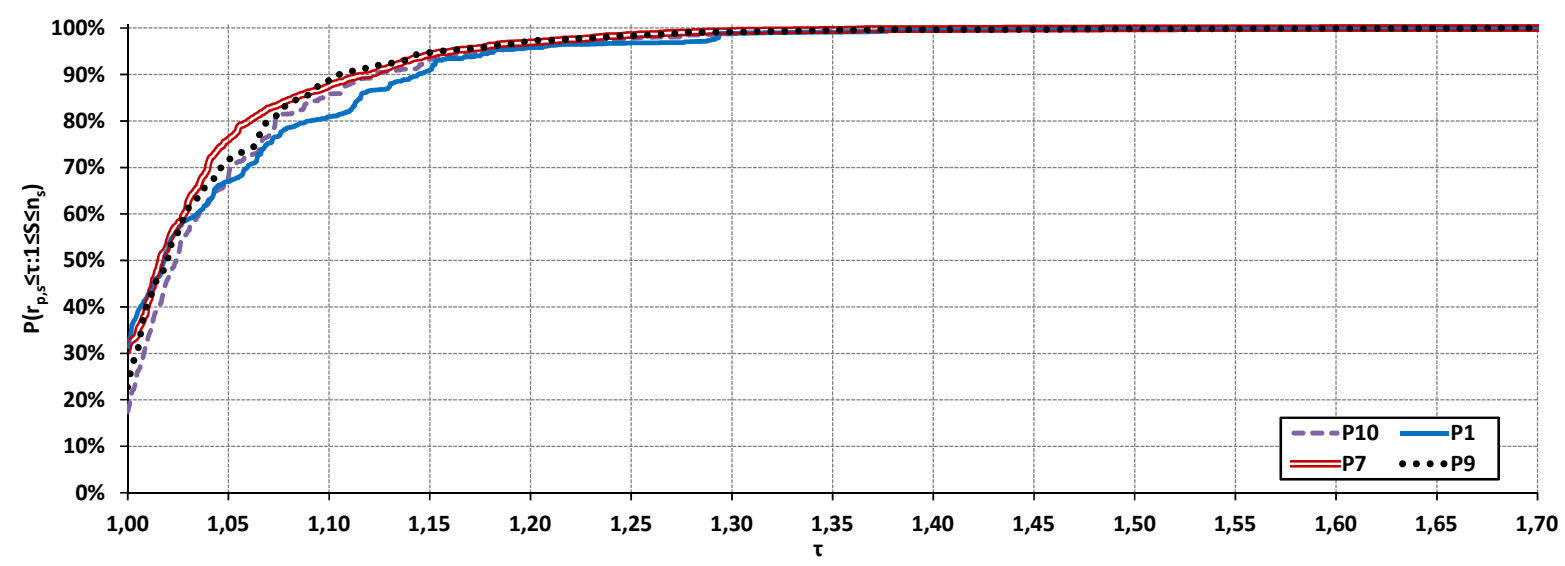

Figura 62: Gráfico de curvas de desempenho dos quatro melhores conjuntos de parâmetros da heurística baseada em ciclos.

\subsubsection{Heurística relaxe-e-fixe}

A parametrização da heurística relaxe-e-fixe foi feita a partir de 18 exemplares escolhidos dentre os 540 gerados. Além disso, como a heurística possui cinco particionamentos distintos para as variáveis do digestor e mais oito particionamentos para as variáveis das máquinas de papel, não consideramos todas as combinações entre os dois grupos de possíveis particionamentos. As combinações utilizadas são apresentadas na Tabela 8. Para cada uma das 20 combinações de partições do digestor e máquinas de papel, foram testados 3 tamanhos de partição, sendo eles pequeno, médio e grande. A Tabela 17 apresenta as 60 variantes geradas, divididas pelas combinações de particionamento. Células vazias indicam combinações que não foram consideradas. Para cada um dos 60 particionamentos testados, foram utilizados os seguintes parâmetros: DF indica o tamanho das partições aplicadas nas variáveis de decisão do digestor; DS é o tamanho da sobreposição entre as partições aplicadas no digestor; PMF é o tamanho das partições aplicadas nas variáveis de decisão das máquinas de papel; e, por fim, PMS é o tamanho da sobreposição entre as partições utilizadas nas máquinas de papel. A diferenciação entre velocidades e micro-períodos no digestor ocorre na escolha do particionamento aplicado. Caso um particionamento por velocidades seja escolhido, DF indicará a quantidade de velocidades 
contidas em cada partição. Por outro lado, se um particionamento por micro-períodos for utilizado, DF indicará a quantidade de micro-períodos que cada partição conterá. A mesma análise vale para os parâmetros DS, PMF e PMS, sendo que na máquina de papel as velocidades são substituídas pelas gramaturas.

Tabela 17: Combinações de particionamentos utilizados.

\begin{tabular}{|c|c|c|c|c|c|c|}
\hline \multicolumn{2}{|c|}{ Digestor } & P1 & P2 & P3 & $\mathrm{P} 4$ & P5 \\
\hline \multirow{8}{*}{ 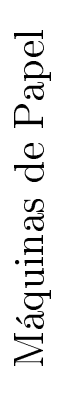 } & $\mathrm{P} 1$ & $1,2,3$ & & & & $37,38,39$ \\
\hline & $\mathrm{P} 2$ & $4,5,6$ & & & & $40,41,42$ \\
\hline & P3 & & $7,8,9$ & & & $43,44,45$ \\
\hline & $\mathrm{P} 4$ & & $10,11,12$ & & & $46,47,48$ \\
\hline & $\mathrm{P} 5$ & & & $13,14,15$ & $25,26,27$ & $49,50,51$ \\
\hline & P6 & & & $16,17,18$ & $28,29,30$ & $52,53,54$ \\
\hline & P7 & & & $19,20,21$ & $31,32,33$ & $55,56,57$ \\
\hline & P8 & & & $22,23,24$ & $34,35,36$ & $58,59,60$ \\
\hline
\end{tabular}

A Tabela 18 apresenta os valores de DF, DS, PMF e PMS para cada uma das 60 variações de particionamento testadas. Esta tabela complementa a apresentação da Tabela 17, que indica quais partições foram utilizadas nas 60 combinações testadas.

Os resultados foram analisados e comparados em duas etapas. Como a heurística relaxe-e-fixe pode ter muitos problemas com infactibilidades em casos nos quais as partições não são bem adaptadas aos exemplares, a primeira etapa consistiu em definir as 7 variantes com a maior quantidade de soluções factíveis. Na segunda etapa, utiliza-se de um gráfico de curvas de desempenho (DM), para selecionar as duas melhores variações. A Tabela 19 apresenta a quantidade de soluções factíveis encontrada por cada variante do relaxe-e-fixe, considerando os 18 exemplares testados. Como podemos verificar, apenas 4 das 60 variantes foram capazes de resolver todos os 18 exemplares, ou seja, as variantes 21, 33, 36 e 51. Outras três variantes, 24, 29 e 35, obtiveram soluções factíveis em 17 dos 18 exemplares. Todas tem em comum a utilização de particionamento por itens nas máquinas de papel e apenas uma está associada a integralização das variáveis do digestor após a fixação das variáveis da máquina de papel (particionamento 5 das variáveis do digestor). Dado que alguns exemplares de teste têm muitos micro-períodos (até 120), o particionamento por micro-períodos pode ter gerado sub-problemas muito pobres no início do processo de resolução, o que ocasionou vários problemas de infactibilidade.

A Figura 63 apresenta o gráfico de curvas de desempenho das 7 variantes da heurística relaxe-e-fixe com maior quantidade de soluções factíveis. Note que 2 das 7 variantes se sobressaíram das demais. A variante RF21 obteve melhores resultados do que as demais 
Tabela 18: Valores utilizados para fixação e sobreposição nos 60 particionamentos testados.

\begin{tabular}{|c|c|c|c|c|c|c|c|c|c|}
\hline Variante & DF & DS & PMF & PMS & Variante & DF & DS & PMF & PMS \\
\hline RF1 & $2 S$ & $S$ & $2 S$ & $S$ & RF31 & 3 & 2 & $K / 6$ & $K / 12$ \\
\hline RF2 & $2 S$ & $S / 2$ & $2 S$ & $S / 2$ & RF32 & 4 & 2 & $K / 4$ & $K / 8$ \\
\hline RF3 & $3 S$ & $S$ & $3 S$ & $S$ & RF33 & 5 & 2 & $K / 3$ & $K / 6$ \\
\hline RF4 & $2 S / M$ & $S / M$ & $2 S / M$ & $S / M$ & RF34 & 3 & 2 & $K / 6$ & $K / 12$ \\
\hline RF5 & $2 S / M$ & $S / 2 M$ & $2 S / M$ & $S / 2 M$ & RF35 & 4 & 2 & $K / 4$ & $K / 8$ \\
\hline RF6 & $3 S / M$ & $S / M$ & $3 S / M$ & $S / M$ & RF36 & 5 & 2 & $K / 3$ & $K / 6$ \\
\hline RF7 & $2 S$ & $S$ & $2 S$ & $S$ & RF37 & $*$ & * & $2 S$ & $S$ \\
\hline RF8 & $2 S$ & $S / 2$ & $2 S$ & $S / 2$ & RF38 & $*$ & $*$ & $2 S$ & $S / 2$ \\
\hline RF9 & $3 S$ & $S$ & $3 S$ & $S$ & RF39 & $*$ & $*$ & $3 S$ & $S$ \\
\hline RF10 & $2 S / M$ & $S / M$ & $2 S / M$ & $S / M$ & RF40 & $*$ & $*$ & $2 S$ & $S$ \\
\hline RF11 & $2 S / M$ & $S / 2 M$ & $2 S / M$ & $S / 2 M$ & RF41 & $*$ & * & $2 S$ & $S / 2$ \\
\hline $\mathrm{RF} 12$ & $3 S / M$ & $S / M$ & $3 S / M$ & $S / M$ & RF42 & $*$ & * & $3 S$ & $S$ \\
\hline RF13 & 3 & 2 & $K / 6$ & $K / 12$ & RF43 & $*$ & * & $2 S$ & $S$ \\
\hline RF14 & 4 & 2 & $K / 4$ & $K / 8$ & RF44 & $*$ & * & $2 S$ & $S / 2$ \\
\hline $\mathrm{RF} 15$ & 5 & 2 & $K / 3$ & $K / 6$ & $\mathrm{RF} 45$ & $*$ & * & $3 S$ & $S$ \\
\hline RF16 & 3 & 2 & $K / 6$ & $K / 12$ & RF46 & $*$ & * & $2 S$ & $S$ \\
\hline RF17 & 4 & 2 & $K / 4$ & $K / 8$ & RF47 & $*$ & $*$ & $2 S$ & $S / 2$ \\
\hline RF18 & 5 & 2 & $K / 3$ & $K / 6$ & RF48 & $*$ & * & $3 S$ & $S$ \\
\hline RF19 & 3 & 2 & $K / 6$ & $K / 12$ & RF49 & $*$ & * & $K / 6$ & $K / 12$ \\
\hline RF20 & 4 & 2 & $K / 4$ & $K / 8$ & RF50 & $*$ & * & $K / 4$ & $K / 8$ \\
\hline RF21 & 5 & 2 & $K / 3$ & $K / 6$ & RF51 & $*$ & * & $K / 3$ & $K / 6$ \\
\hline $\mathrm{RF} 22$ & 3 & 2 & $K / 6$ & $K / 12$ & RF52 & $*$ & $*$ & $K / 6$ & $K / 12$ \\
\hline RF23 & 4 & 2 & $K / 4$ & $K / 8$ & RF53 & $*$ & * & $K / 4$ & $K / 8$ \\
\hline $\mathrm{RF} 24$ & 5 & 2 & $K / 3$ & $K / 6$ & RF54 & $*$ & $*$ & $K / 3$ & $K / 6$ \\
\hline $\mathrm{RF} 25$ & 3 & 2 & $K / 6$ & $K / 12$ & RF55 & $*$ & $*$ & $K / 6$ & $K / 12$ \\
\hline RF26 & 4 & 2 & $K / 4$ & $K / 8$ & RF56 & $*$ & $*$ & $K / 4$ & $K / 8$ \\
\hline $\mathrm{RF} 27$ & 5 & 2 & $K / 3$ & $K / 6$ & RF57 & $*$ & $*$ & $K / 3$ & $K / 6$ \\
\hline RF28 & 3 & 2 & $K / 6$ & $K / 12$ & RF58 & $*$ & $*$ & $K / 6$ & $K / 12$ \\
\hline RF29 & 4 & 2 & $K / 4$ & $K / 8$ & RF59 & $*$ & $*$ & $K / 4$ & $K / 8$ \\
\hline RF30 & 5 & 2 & $K / 3$ & $K / 6$ & RF60 & $*$ & $*$ & $K / 3$ & $K / 6$ \\
\hline
\end{tabular}

entre $\tau=1$ até aproximadamente $\tau=1,465$, enquanto a variante RF33 obteve resultados superiores a partir deste valor e atingiu 100\% dos exemplares em $\tau<1,52$. Por esta razão, as variantes RF21 e RF33 são utilizadas nos testes comparativos finais com as demais heurísticas e na combinação com as heurísticas de melhoria.

A variante RF21 utiliza o particionamento P3 no digestor (partição por velocidade das extremidades para o centro) e particionamento P7 nas variáveis de decisão das máquinas de papel (partição por produtos ordenados por preço). Foram utilizadas partições com 5 velocidades fixadas a cada iteração e 2 velocidades de sobreposição no digestor. 
Tabela 19: Quantidade de soluções factíveis encontradas por cada variante da heurística relaxe-e-fixe.

\begin{tabular}{rrrrrr}
\hline Variante & \# factíveis & Variante & \# factíveis & Variante & \# factíveis \\
\hline RF1 & 11 & RF21 & $\mathbf{1 8}$ & RF41 & 10 \\
RF2 & 10 & RF22 & 15 & RF42 & 10 \\
RF3 & 10 & RF23 & 16 & RF43 & 10 \\
RF4 & 10 & RF24 & $\mathbf{1 7}$ & RF44 & 9 \\
RF5 & 10 & RF25 & 13 & RF45 & 11 \\
RF6 & 10 & RF26 & 13 & RF46 & 9 \\
RF7 & 10 & RF27 & 13 & RF47 & 9 \\
RF8 & 10 & RF28 & 15 & RF48 & 10 \\
RF9 & 11 & RF29 & $\mathbf{1 7}$ & RF49 & 14 \\
RF10 & 10 & RF30 & 15 & RF50 & 15 \\
RF11 & 10 & RF31 & 11 & RF51 & $\mathbf{1 8}$ \\
RF12 & 10 & RF32 & 16 & RF52 & 12 \\
RF13 & 13 & RF33 & $\mathbf{1 8}$ & RF53 & 14 \\
RF14 & 16 & RF34 & 16 & RF54 & 14 \\
RF15 & 16 & RF35 & $\mathbf{1 7}$ & RF55 & 15 \\
RF16 & 15 & RF36 & $\mathbf{1 8}$ & RF56 & 13 \\
RF17 & 16 & RF37 & 10 & RF57 & 16 \\
RF18 & 15 & RF38 & 10 & RF58 & 12 \\
RF19 & 13 & RF39 & 11 & RF59 & 13 \\
RF20 & 16 & RF40 & 10 & RF60 & 13 \\
\hline
\end{tabular}

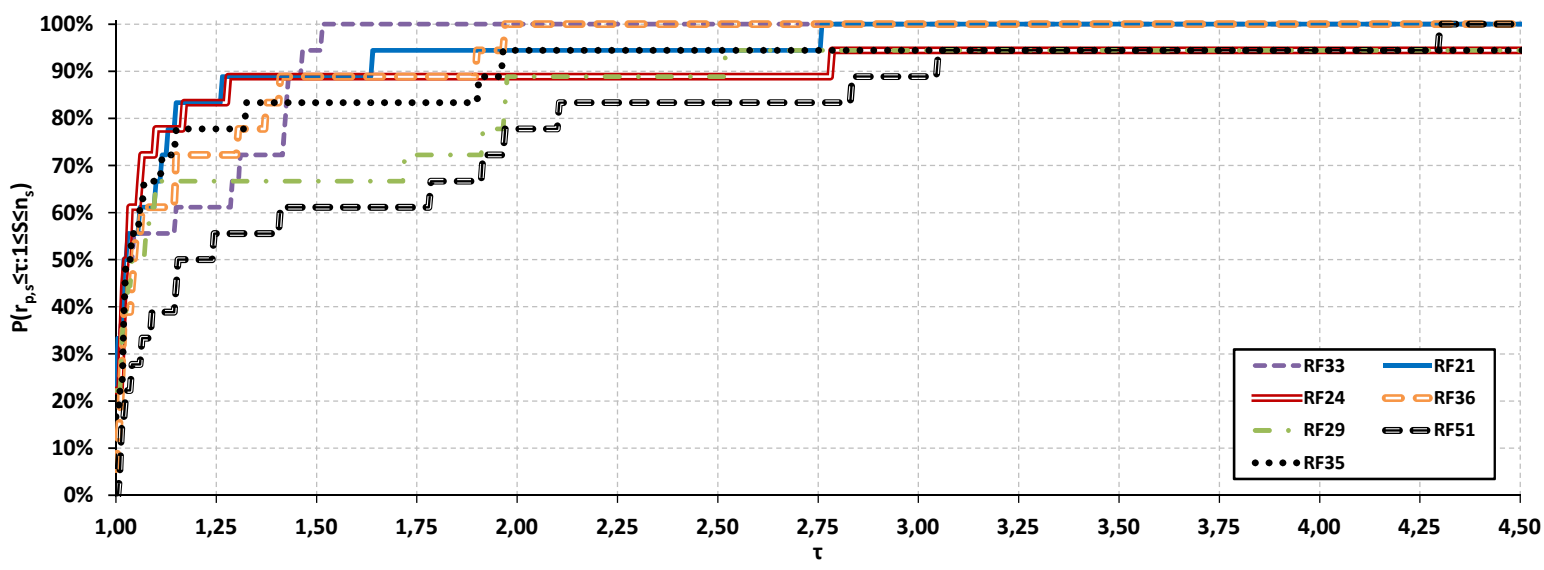

Figura 63: Gráfico de curvas de desempenho dos sete melhores conjuntos de parâmetros da heurística relaxe-e-fixe.

Nas máquinas de papel, considerou-se $K / 3$ itens fixados por partição com $K / 6$ itens na partição de sobreposição, onde $K$ é a quantidade de gramaturas existentes no problema , conforme Tabela 18.

Por outro lado, a variante RF33 é composta pelo particionamento P4 no digestor (partição por velocidade do centro para as extremidades) e particionamento P7 nas má- 
quinas de papel (partição por produtos ordenados por preço). Além de utilizar o mesmo particionamento nas máquinas de papel, os tamanhos das partições de fixação e sobreposição das duas melhores variantes foi o mesmo. Isto demonstra o bom funcionamento do particionamento por itens com ordenação de preços e, de certa forma, o baixo nível de influência do particionamento das variáveis do digestor sobre a qualidade das soluções finais. O bom funcionamento do método não aparenta ter dependido da ordem de fixação das variáveis de decisão do digestor (do centro para as extremidades ou das extremidades para o centro), mas teve influência da forma como estas foram divididas.

\subsubsection{Heurística fixe-e-otimize}

A parametrização dos métodos fixe-e-otimize foi realizada de forma similar ao realizado na heurística relaxe-e-fixe. Como o particionamento é ligeiramente diferente e pode-se definir particionamentos distintos para serem aplicados sequencialmente, as possibilidades de combinações são maiores. Neste caso, optamos por aplicar 3 tipos diferentes de particionamento em sequência e variar o tamanho das partições de cada tipo, a fim de obter todas as combinações analisadas. Foram utilizados três tipos distintos de particionamento para as heurísticas fixe-e-otimize. Estes particionamentos são apresentados na Seção 4.5.1. Os particionamentos foram aplicados na seguinte ordem:

1. Particionamento por micro-períodos e máquinas (Particionamento 1)

2. Particionamento por itens e máquinas (Particionamento 2)

3. Particionamento por itens e períodos (Particionamento 3)

Estas variações se diferem nos tamanhos dos três tipos de particionamento aplicados. Foram testados 3 opções de tamanho para o particionamento 1, 3 opções de tamanho para o particionamento 2 e 4 tamanhos para o particionamento 3. A combinação destas opções de cada particionamento gerou um total de 36 variantes de parâmetros, que são apresentados na Tabela 20. Estes tamanhos de partições são utilizados no processo de parametrização do restante desta seção.

Como a heurística fixe-e-otimize é um método de melhoria de soluções, ela necessita de uma solução inicial para que o procedimento possa ser iniciado. Para esta tarefa, foram utilizadas a heurística construtiva gulosa (Seção 4.1) e a heurística baseada em ciclos (Seção 4.3). Estas duas heurísticas construtivas apresentaram resultados razoáveis 
Tabela 20: Conjunto de parâmetros das 36 variantes de fixe-e-otimize testadas.

\begin{tabular}{lcccccccccccc}
\hline & \multicolumn{3}{c}{ Particionamento 1} & \multicolumn{3}{c}{ Particionamento 2} & \multicolumn{3}{c}{ Particionamento 3} \\
Variante & TF & TS & MF & MS & KF & KS & MF & MS & TF & TS & KF & KS \\
\hline FO1 & 4 & 2 & 2 & 0 & 2 & 1 & 1 & 0 & 16 & 8 & 4 & 2 \\
FO2 & 4 & 2 & 2 & 0 & 2 & 1 & 1 & 0 & 16 & 8 & 8 & 4 \\
FO3 & 4 & 2 & 2 & 0 & 2 & 1 & 1 & 0 & 24 & 12 & 4 & 2 \\
FO4 & 4 & 2 & 2 & 0 & 2 & 1 & 1 & 0 & 24 & 12 & 8 & 4 \\
FO5 & 4 & 2 & 2 & 0 & 2 & 1 & 2 & 0 & 16 & 8 & 4 & 2 \\
FO6 & 4 & 2 & 2 & 0 & 2 & 1 & 2 & 0 & 16 & 8 & 8 & 4 \\
FO7 & 4 & 2 & 2 & 0 & 2 & 1 & 2 & 0 & 24 & 12 & 4 & 2 \\
FO8 & 4 & 2 & 2 & 0 & 2 & 1 & 2 & 0 & 24 & 12 & 8 & 4 \\
FO9 & 4 & 2 & 2 & 0 & 4 & 2 & 1 & 0 & 16 & 8 & 4 & 2 \\
FO10 & 4 & 2 & 2 & 0 & 4 & 2 & 1 & 0 & 16 & 8 & 8 & 4 \\
FO11 & 4 & 2 & 2 & 0 & 4 & 2 & 1 & 0 & 24 & 12 & 4 & 2 \\
FO12 & 4 & 2 & 2 & 0 & 4 & 2 & 1 & 0 & 24 & 12 & 8 & 4 \\
FO13 & 8 & 4 & 1 & 0 & 2 & 1 & 1 & 0 & 16 & 8 & 4 & 2 \\
FO14 & 8 & 4 & 1 & 0 & 2 & 1 & 1 & 0 & 16 & 8 & 8 & 4 \\
FO15 & 8 & 4 & 1 & 0 & 2 & 1 & 1 & 0 & 24 & 12 & 4 & 2 \\
FO16 & 8 & 4 & 1 & 0 & 2 & 1 & 1 & 0 & 24 & 12 & 8 & 4 \\
FO17 & 8 & 4 & 1 & 0 & 2 & 1 & 2 & 0 & 16 & 8 & 4 & 2 \\
FO18 & 8 & 4 & 1 & 0 & 2 & 1 & 2 & 0 & 16 & 8 & 8 & 4 \\
FO19 & 8 & 4 & 1 & 0 & 2 & 1 & 2 & 0 & 24 & 12 & 4 & 2 \\
FO20 & 8 & 4 & 1 & 0 & 2 & 1 & 2 & 0 & 24 & 12 & 8 & 4 \\
FO21 & 8 & 4 & 1 & 0 & 4 & 2 & 1 & 0 & 16 & 8 & 4 & 2 \\
FO22 & 8 & 4 & 1 & 0 & 4 & 2 & 1 & 0 & 16 & 8 & 8 & 4 \\
FO23 & 8 & 4 & 1 & 0 & 4 & 2 & 1 & 0 & 24 & 12 & 4 & 2 \\
FO24 & 8 & 4 & 1 & 0 & 4 & 2 & 1 & 0 & 24 & 12 & 8 & 4 \\
FO25 & 8 & 4 & 2 & 0 & 2 & 1 & 1 & 0 & 16 & 8 & 4 & 2 \\
FO26 & 8 & 4 & 2 & 0 & 2 & 1 & 1 & 0 & 16 & 8 & 8 & 4 \\
FO27 & 8 & 4 & 2 & 0 & 2 & 1 & 1 & 0 & 24 & 12 & 4 & 2 \\
FO28 & 8 & 4 & 2 & 0 & 2 & 1 & 1 & 0 & 24 & 12 & 8 & 4 \\
FO29 & 8 & 4 & 2 & 0 & 2 & 1 & 2 & 0 & 16 & 8 & 4 & 2 \\
FO30 & 8 & 4 & 2 & 0 & 2 & 1 & 2 & 0 & 16 & 8 & 8 & 4 \\
FO31 & 8 & 4 & 2 & 0 & 2 & 1 & 2 & 0 & 24 & 12 & 4 & 2 \\
FO32 & 8 & 4 & 2 & 0 & 2 & 1 & 2 & 0 & 24 & 12 & 8 & 4 \\
FO33 & 8 & 4 & 2 & 0 & 4 & 2 & 1 & 0 & 16 & 8 & 4 & 2 \\
FO34 & 8 & 4 & 2 & 0 & 4 & 2 & 1 & 0 & 16 & 8 & 8 & 4 \\
FO35 & 8 & 4 & 2 & 0 & 4 & 2 & 1 & 0 & 24 & 12 & 4 & 2 \\
FO36 & 8 & 4 & 2 & 0 & 4 & 2 & 1 & 0 & 24 & 12 & 8 & 4 \\
\hline & & & & & & & & & & & &
\end{tabular}

em tempos computacionais reduzidos. Além disso, após a parametrização, ambas conseguiram gerar soluções factíveis em todas os exemplares testados (seções 6.3.1 e 6.3.2). Como foi proposta uma variação da heurística fixe-e-otimize com modificações na função objetivo, foi necessário uma comparação completa entre os métodos considerando mais 
de um tipo de solução inicial. Isto se faz necessário para garantir que um padrão de solução inicial construída não esteja influenciando a avaliação do método de melhoria. Além disso, a parametrização deve ser feita com cada uma das combinações de métodos para garantir um ajuste mais adequado com as características de solução de cada combinação. Foram geradas quatro combinações de solução entre as heurísticas construtivas HCG e HCBC e os dois métodos de melhoria. A nomenclatura utilizada para diferenciar estas combinações foi a seguinte:

- Fixe-e-otimize Tradicional + Heurística Construtiva Gulosa (FT-HCG)

- Fixe-e-otimize Tradicional + Heurística Construtiva Baseada em Ciclos (FT-HCBC)

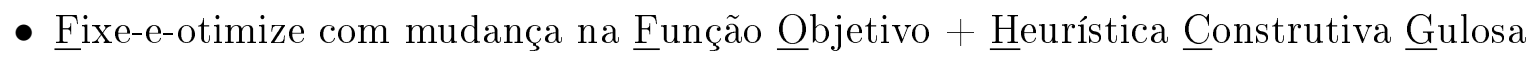
(FFO-HCG)

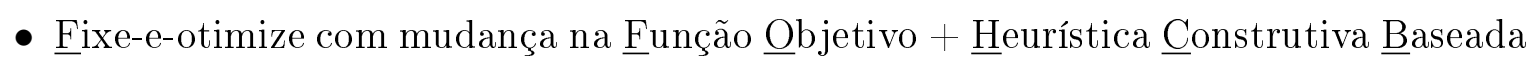

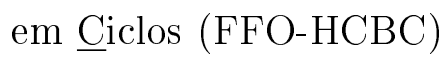

A seleção das melhores variantes foi realizada em dois passos. No primeiro passo, a escolha das cinco melhores opções para análise do gráfico de curvas de desempenho é feita a partir do desvio relativo ( gap) médio. No segundo passo, as variantes com as cinco melhores médias sao comparadas via gráfico de curvas de desempenho (DM). Os resultados das parametrizações destas quatro combinações de métodos são apresentados nas seções 6.3.4.1 a 6.3.4.4, sendo que apenas um conjunto de parâmetros foi selecionado para cada combinação de métodos. A Seção 6.3.4.5 apresenta o processo de parametrização das combinações entre as variantes RF21 e RF33 da heurística relaxe-e-fixe com a heurística fixe-e-otimize com mudança na função objetivo (FFO). Nestes testes foram utilizados tempos limites de 1800 e 3600 segundos para a heurística relaxe-e-fixe. A combinação dos dois tempos de execução com as duas variantes da heurística construtiva gerou outras 4 combinações de métodos nomeadas RF21FFO1800, RF21FFO3600, RF33FFO1800 e RF33FFO3600. Para cada uma das oito combinações de heurística construtiva e melhoria via fixe-e-otimize, foram realizados 648 testes (18 exemplares e 36 conjuntos de parâmetros) limitados a 3600 segundos cada.

\subsubsection{Parametrização da heurística fixe-e-otimize FT-HCG}

A Tabela 21 apresenta os desvios percentuais médio obtidos pela heurística FT-HCG considerando cada conjunto de parâmetros. Os cinco melhores conjuntos de parâmetros, 
selecionados para comparação nos gráficos de curva de desempenho, foram destacados em negrito. O desvio percentual médio geral foi de 16,27\% e a diferença máxima das médias das cinco melhores variantes ficou em $0,46 \%$.

Tabela 21: Desvio percentual médio (\%) das variantes do método FT-HCG.

\begin{tabular}{cccccccc}
\hline Variante & Desvio & Variante & Desvio & Variante & Desvio & Variante & Desvio \\
\hline FO1 & 16,13 & FO10 & 16,62 & FO19 & $\mathbf{1 5 , 7 0}$ & FO28 & 16,73 \\
FO2 & 16,63 & FO11 & 15,97 & FO20 & 16,40 & FO29 & 16,31 \\
FO3 & $\mathbf{1 5 , 7 6}$ & FO12 & 16,64 & FO21 & $\mathbf{1 5 , 8 1}$ & FO30 & 16,77 \\
FO4 & 16,53 & FO13 & 15,98 & FO22 & 16,40 & FO31 & 15,98 \\
FO5 & 15,83 & FO14 & 16,27 & FO23 & 16,52 & FO32 & 16,68 \\
FO6 & 16,69 & FO15 & 15,94 & FO24 & 16,82 & FO33 & 15,82 \\
FO7 & 15,87 & FO16 & 16,43 & FO25 & $\mathbf{1 5 , 7 1}$ & FO34 & 16,65 \\
FO8 & 16,65 & FO17 & $\mathbf{1 5 , 3 5}$ & FO26 & 16,64 & FO35 & 15,89 \\
FO9 & 16,15 & FO18 & 16,26 & FO27 & 16,23 & FO36 & 16,97 \\
\hline
\end{tabular}

A Figura 64 apresenta o gráfico de curvas de desempenho dos melhores conjuntos de parâmetros da heurística FT-HCG. A diferença máxima encontrada entre a solução de uma das variantes e a melhor solução é substancialmente menor do que a encontrada nas análises feitas para a heurística relaxe-e-fixe. Isto indica que a heurística fixe-e-otimize é menos sensível ao particionamento do que o método anterior. Neste gráfico temos dois conjuntos de particionamento que se destacam aos demais, sendo eles as variantes FO17 e FO25. A variante FO25 se consolida como a melhor variante com $\tau$ entre 1 e 1,015, enquanto a variante FO17 domina todas as curvas a partir de $\tau=1,018$ e atinge $100 \%$ dos exemplares em primeiro lugar, pouco após $\tau=1,045$.

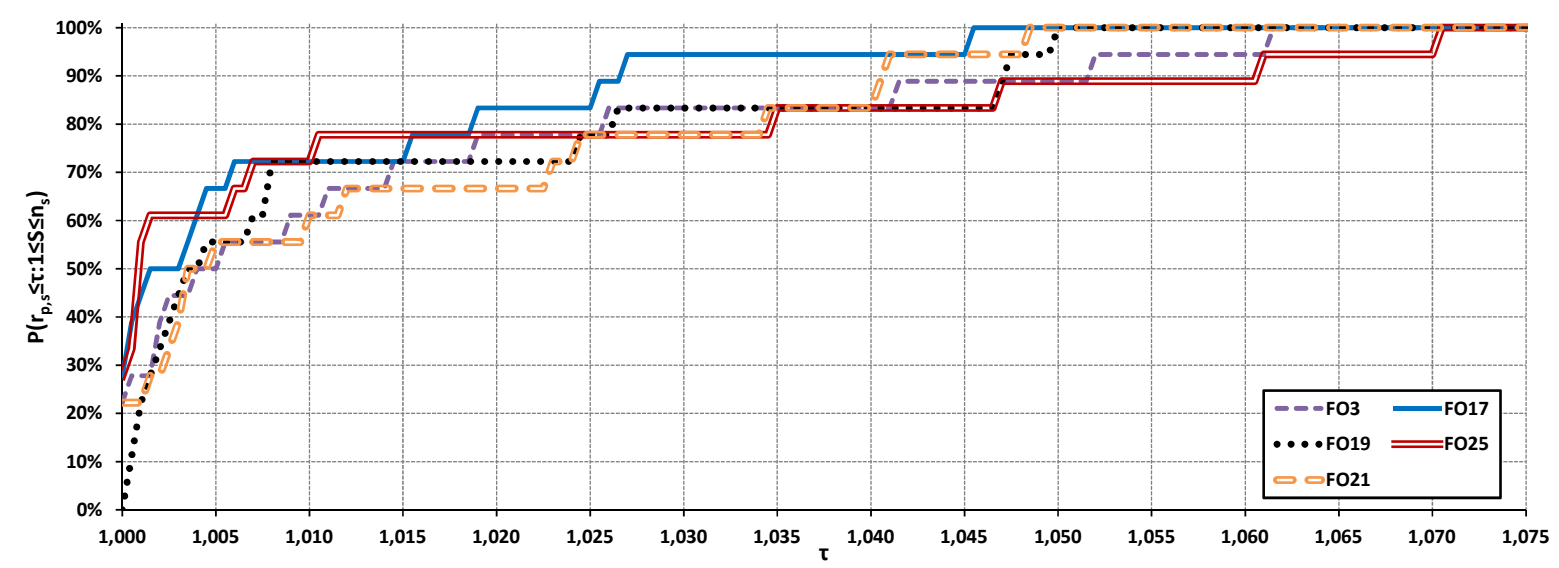

Figura 64: Gráfico de curvas de desempenho (DM) dos cinco melhores conjuntos de parâmetros para a heurística FT-HCG.

Dado que a faixa de domínio da variante FO25 termina em um valor de $\tau$ muito baixo, a variante FO17 foi escolhida como a melhor parametrização para a heurística FT-HCG. 
O particionamento por períodos e máquinas é composto por partições com tamanho de oito micro-períodos por uma máquina, sendo que há uma sobreposição de quatro destes micro-períodos. O particionamento por itens e máquinas é feito com duas gramaturas por duas máquinas em cada partição e tendo uma gramatura sobreposta entre partições subsequentes. As partições em forma de cubo são construídas com tamanho de dezesseis micro-períodos e quatro gramaturas. As sobreposições entre partições vizinhas, neste caso, são de oito micro-períodos e/ou duas gramaturas (Tabela 20).

Os tempos computacionais médios do FT-HCG com os variados conjuntos de parâmetros variaram entre 2236, 93 e 3064, 66 segundos. A variante FO17 obteve vantagem sobre a FO25 no tempo computacional. O tempo médio de solução da FO17 foi de 2468, 80 segundos, enquanto a FO25 obteve um tempo computacional médio de 2757, 30 segundos.

\subsubsection{Parametrização da heurística fixe-e-otimize FT-HCBC}

A heurística FT-HCBC apresenta resultados ligeiramente inferiores aos encontrados para a heurística FT-HCG, como pode ser verificado na Tabela 22. O desvio percentual médio geral foi de $16,37 \%$, apenas $0,1 \%$ abaixo do encontrado anteriormente. No caso das cinco melhores variantes, os resultados foram ligeiramente melhores do que os encontrados anteriormente, cerca de 0,28\% superior no caso do melhor conjunto de parâmetros. A dispersão máxima entre as médias dos 36 conjuntos de parâmetros também foi superior e alcançou $0,67 \%$ entre os cinco melhores conjuntos.

Tabela 22: Desvio percentual médio (\%) das variantes do método FT-HCBC.

\begin{tabular}{cccccccc}
\hline Variante & Desvio & Variante & Desvio & Variante & Desvio & Variante & Desvio \\
\hline FO1 & 15,72 & FO10 & 15,87 & FO19 & $\mathbf{1 5 , 0 7}$ & FO28 & 16,53 \\
FO2 & 16,45 & FO11 & $\mathbf{1 5 , 5 7}$ & FO20 & 16,16 & FO29 & 17,19 \\
FO3 & 16,34 & FO12 & 18,01 & FO21 & 16,30 & FO30 & 16,45 \\
FO4 & 16,73 & FO13 & 15,81 & FO22 & 16,46 & FO31 & 16,32 \\
FO5 & 16,46 & FO14 & 16,17 & FO23 & 16,43 & FO32 & 17,36 \\
FO6 & 16,83 & FO15 & 15,69 & FO24 & 16,39 & FO33 & 16,37 \\
FO7 & 15,85 & FO16 & 16,65 & FO25 & 16,44 & FO34 & 17,07 \\
FO8 & 17,54 & FO17 & $\mathbf{1 5 , 6 3}$ & FO26 & 16,47 & FO35 & 16,17 \\
FO9 & $\mathbf{1 5 , 5 1}$ & FO18 & $\mathbf{1 6 , 8 7}$ & FO27 & $\mathbf{1 5 , 5 5}$ & FO36 & 16,96 \\
\hline
\end{tabular}

O gráfico da Figura 65 apresenta um comportamento similar ao encontrado no gráfico da Figura 64, onde um método não domina os demais completamente para qualquer valor de $\tau$. Entretanto, temos novamente algumas variantes que se sobressaem em relação às demais. São candidatas às melhores variantes FO19, FO09 e FO17. Cada uma delas do- 
mina em uma faixa diferente de $\tau$. Considerando um desempenho geral, pode-se verificar que dentre as três, a FO19 é a variante que domina as demais por intervalos maiores de $\tau$. Além disso, ela tem desempenho bem próximo ao das demais quando não é a melhor variante para um determinado valor de $\tau$. A variante FO19 também é a primeira a chegar em $100 \%$ das soluções e a variante que tem a maior quantidade de melhores soluções.

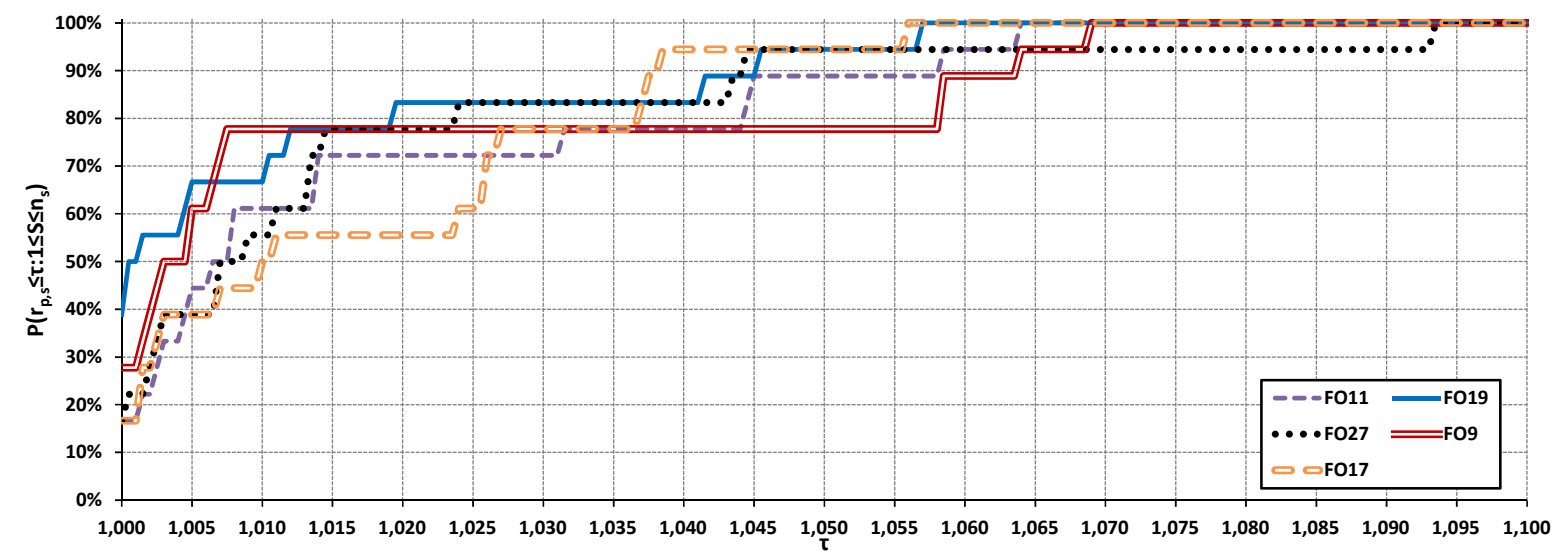

Figura 65: Gráfico de curvas de desempenho dos cinco melhores conjuntos de parâmetros da heurística FT-HCBC.

FO19 possui um particionamento por períodos e máquinas de tamanho oito microperíodos por uma máquina e sobreposição de quatro períodos. O particionamento por itens e máquinas leva em consideração dois itens por duas máquinas em cada partição, sendo que um item é compartilhado por partições subsequentes (sobreposição). Finalmente, o particionamento em forma de cubo é composto por vinte e quatro micro-períodos e quatro itens, compartilhando até doze micro-períodos e dois itens com partições vizinhas (Tabela 20).

Os tempos computacionais médios do método FT-HCBC variaram de 2322, 17 até 3159, 02 segundos, sendo que a variante FO19 obteve uma média de 2478,92. Este valor ficou entre os cinco melhores tempos computacionais das 36 variantes. A diferença de tempo com o método FT-HCG pode ser devido à necessidade de maior tempo da heurística construtiva, principalmente no caso de exemplares maiores.

\subsubsection{Parametrização da heurística fixe-e-otimize FFO-HCG}

Os resultados para a heurística FFO-HCG, apresentados na Tabela 23, demonstram uma melhora visível sobre os resultados do método FT-HCG. Estes métodos tem a mesma solução de partida, mas diferem na forma como o fixe-e-otimize foi implementado. Aqui aplicamos a modificação na função objetivo (Seção 4.5.3), enquanto o FT-HCG tem uma 
implementação tradicional da heurística (Seção 4.5.2). O desvio percentual médio de todos os conjuntos de parâmetros foi de 14,41\%, contra 16, $27 \%$ da implementação tradicional, uma diferença de 1,86\%. A variação encontrada entre as cinco melhores parametrizações de FFO-HCG foi de 0,03\% no desvio médio e a melhor variante foi FO35, que atingiu desvio percentual médio igual a $14,15 \%$.

Tabela 23: Desvio percentual médio (\%) das variantes do método FFO-HCG.

\begin{tabular}{cccccccc}
\hline Variante & Desvio & Variante & Desvio & Variante & Desvio & Variante & Desvio \\
\hline FO1 & 14,34 & FO10 & $\mathbf{1 4 , 1 6}$ & FO19 & 14,37 & FO28 & 14,65 \\
FO2 & 14,35 & FO11 & $\mathbf{1 4 , 1 6}$ & FO20 & 14,58 & FO29 & 14,32 \\
FO3 & 14,28 & FO12 & 14,33 & FO21 & 14,60 & FO30 & 14,52 \\
FO4 & 14,36 & FO13 & 14,62 & FO22 & 14,55 & FO31 & 14,32 \\
FO5 & 14,19 & FO14 & 14,55 & FO23 & 14,65 & FO32 & 14,56 \\
FO6 & 14,72 & FO15 & 14,68 & FO24 & 14,40 & FO33 & $\mathbf{1 4 , 1 8}$ \\
FO7 & 14,37 & FO16 & 14,53 & FO25 & 14,20 & FO34 & 14,29 \\
FO8 & 14,32 & FO17 & 14,43 & FO26 & 14,34 & FO35 & $\mathbf{1 4 , 1 5}$ \\
FO9 & 14,35 & FO18 & 14,48 & FO27 & $\mathbf{1 4 , 1 7}$ & FO36 & 14,61 \\
\hline
\end{tabular}

A variação pequena no desvio percentual médio também pode ser verificada no gráfico de curvas de desempenho da Figura 66. Neste gráfico, $\tau$ varia de 1 até 1,045, ou seja, não existe nenhuma solução destas cinco variantes que seja $4,5 \%$ pior do que a melhor solução para o mesmo exemplar. Novamente, duas variantes se sobressaem e dominam parte do gráfico. A variante FO11 domina o início do gráfico de $\tau>1$ até próximo de $\tau=1,011$, com perdas em alguns pontos. Após isto, ocorre um empate com a variante FO10 até $\tau=1,013$, que domina o restante do gráfico. A quantidade de melhores soluções das duas variantes equivalem ambas a um terço das soluções (6 melhores soluções em 18 exemplares). O desempenho da variante FO11 foi ruim apenas para um dos exemplares do conjunto de parametrização, a de maior porte. Como exemplares de grande porte tem uma relevância prática (são mais próximas da realidade), e por terem um desempenho similar nas demais soluções, optou-se pela variante FO10 como a melhor opção para a fixe-e-otimize FFO-HCG.

Além de melhorar os resultados com relação ao desvio percentual médio (Tabela 23), o método FFO-HCG obteve tempos computacionais cerca de $26 \%$ inferiores aos da heurística FT-HCG. As variantes obtiveram tempos computacionais médios de 1056, 88 até 2264, 91 segundos e FO10 obteve uma média de 1987, 13 segundos. Este resultado de tempo não está entre os melhores quando comparado as demais variantes, mas é 481 segundos melhor do que a melhor parametrização de FT-HCG. Estes resultados preliminares indicam ganhos do método proposto que poderão ser visto em mais detalhes nos 


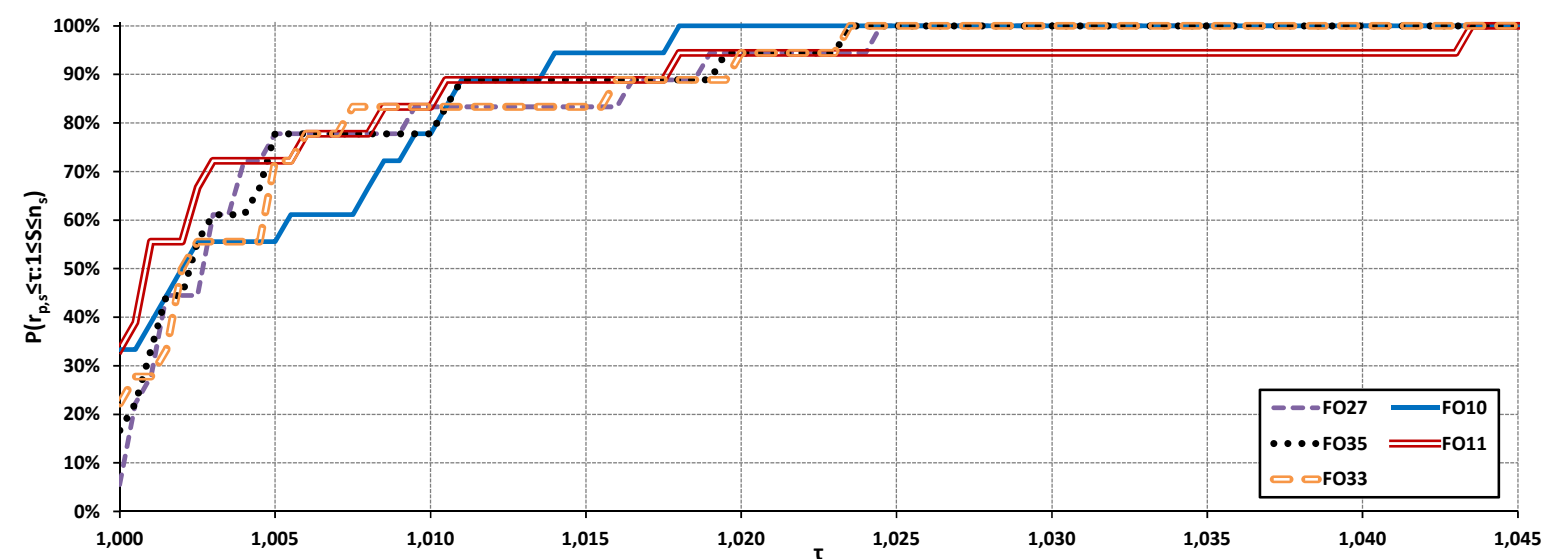

Figura 66: Gráfico de curvas de desempenho dos cinco melhores conjuntos de parâmetros da heurística FFO-HCG.

testes computacionais completos da Seção 6.4.

A parametrização da variante FO10 tem particionamento por períodos e máquinas. As partições construídas têm tamanho de quatro micro-períodos por duas máquinas, com sobreposição de dois micro-períodos entre partições vizinhas. No particionamento por itens e máquinas foram utilizados quatro itens por uma máquina de tamanho nas partições. A sobreposição definida foi de apenas dois itens entre partições vizinhas. As partições em forma de cubo têm dezesseis micro-períodos por oito itens. Além disso, a sobreposição considerada foi de oito micro-períodos e quatro gramaturas (conforme Tabela 20).

\subsubsection{Parametrização da heurística fixe-e-otimize FFO-HCBC}

A Tabela 24 apresenta os desvios médios obtidos pelo método FFO-HCBC com cada conjunto de parâmetros. O resultado médio geral foi de 14,66\%,1,71\% superior ao obtido pela combinação FT-HCBC. A dispersão das cinco melhores variantes ficou em 0,19\%, valor abaixo dos encontrados nos métodos FT-HCG e FT-HCBC. Isto pode indicar que a adição da mudança na função objetivo, além de possibilitar a geração de soluções de melhor qualidade, ajuda a sair de mínimos locais gerados pelo particionamento.

A Figura 67 tem comportamento parecido com os demais gráficos do processo de parametrização das heurísticas fixe-e-otimize. As variantes FO20 e FO22 dominaram as demais combinações de parâmetros e se consolidam como os melhores conjuntos de parâmetros. FO22 se comporta melhor para $\tau<1,009$ e FO20 se consolida como a melhor a partir deste ponto. Neste caso temos uma competição entre a parametrização com maior quantidade de melhores soluções (FO22) e o conjunto de parâmetros que chega a 100\% com menor $\tau$ e com menor desvio percentual médio (FO20). Como um 
Tabela 24: Desvio percentual médio (\%) das variantes do método FFO-HCBC.

\begin{tabular}{cccccccc}
\hline Variante & Desvio & Variante & Desvio & Variante & Desvio & Variante & Desvio \\
\hline FO1 & $\mathbf{1 4 , 4 6}$ & FO10 & $\mathbf{1 4 , 4 7}$ & FO19 & 14,74 & FO28 & 14,78 \\
FO2 & 14,65 & FO11 & 14,49 & FO20 & $\mathbf{1 4 , 2 8}$ & FO29 & 14,79 \\
FO3 & 14,68 & FO12 & 14,70 & FO21 & 14,50 & FO30 & 15,09 \\
FO4 & 14,53 & FO13 & 14,89 & FO22 & $\mathbf{1 4 , 4 1}$ & FO31 & 14,71 \\
FO5 & $\mathbf{1 4 , 4 2}$ & FO14 & 14,71 & FO23 & 14,54 & FO32 & 14,80 \\
FO6 & 14,52 & FO15 & 14,63 & FO24 & 14,61 & FO33 & 14,75 \\
FO7 & 14,91 & FO16 & 14,69 & FO25 & 14,66 & FO34 & 14,65 \\
FO8 & 14,86 & FO17 & 14,51 & FO26 & 14,83 & FO35 & 14,50 \\
FO9 & 14,81 & FO18 & 14,74 & FO27 & 14,87 & FO36 & 14,56 \\
\hline
\end{tabular}

valor de $\tau=1,009$ equivale a indicar uma perda de 0,9\%, optamos pela variante FO20 que apresenta maior robustez e qualidade média.

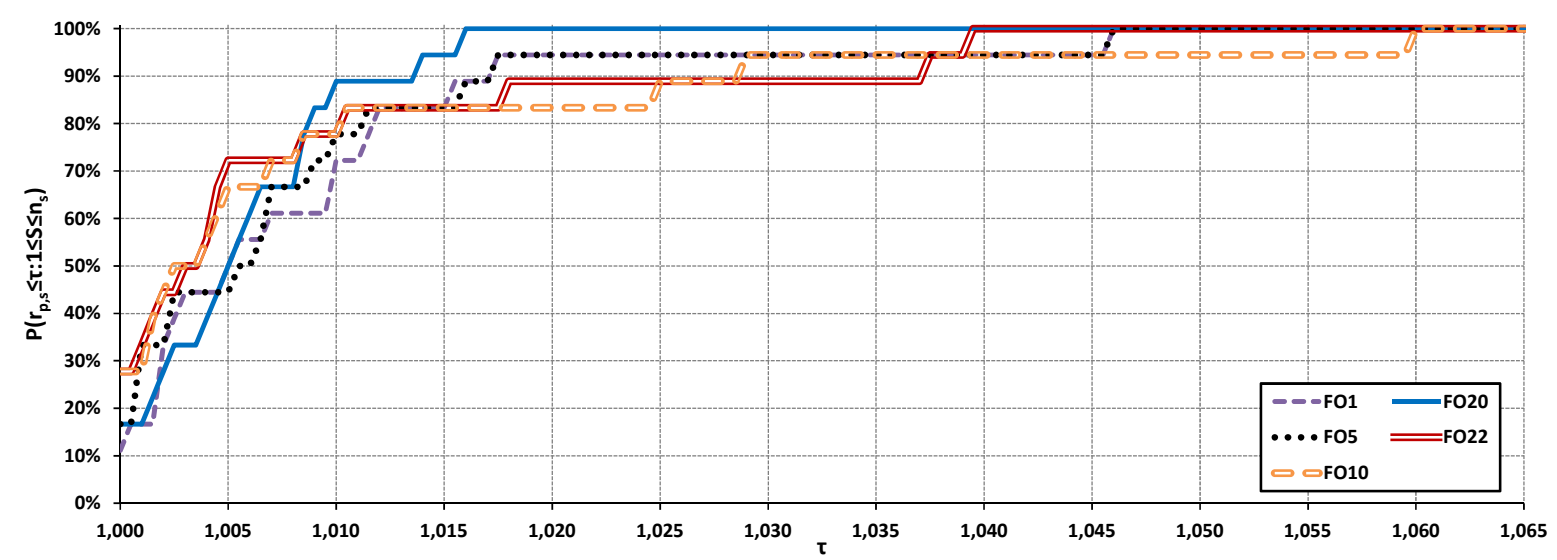

Figura 67: Gráfico de curvas de desempenho dos cinco melhores conjuntos de parâmetros da heurística FFO-HCBC.

O tempo computacional médio do método FFO-HCBC variou entre 1207, 67 e 2358, 89 segundos e a variante FO20 teve valor médio de 2045, 28 segundos. A melhoria no tempo computacional com relação a FT-HCBC foi similar a encontrada no caso do método FFOHCG com relação a FT-HCG. Isto indica que a melhoria no método ocorreu independente da solução inicial. O particionamento de melhor qualidade, por outro lado, parece ter influência da solução inicial e da forma como o método é desenvolvido, pois variou de acordo com a combinação de métodos testada.

A variante FO20 conta com um particionamento por períodos e máquinas com oito micro-períodos e uma máquina por partição, onde quatro micro-períodos são compartilhados entre partições subsequentes. O particionamento por itens e máquina foi utilizado contendo dois itens e duas máquinas por partição e sobreposição de um item com cada 
vizinho. As partições quadradas tem tamanho vinte e quatro micro-períodos e oito itens de tamanho. A sobreposição entre partições vizinhas é de doze micro-períodos e quatro itens, conforme Tabela 20.

\subsubsection{Parametrização das heurísticas fixe-e-otimize FFO-RF}

Nesta seção, são realizados testes com a combinação de variantes das heurísticas relaxe-e-fixe e fixe-e-otimize. Foram consideradas nestes testes as duas melhores variantes de relaxe-e-fixe, RF21 e RF33, e a variante da heurística fixe-e-otimize com mudança na função objetivo (FFO). Quando combinada com as heurísticas HCG e HCBC, a heurística de melhoria FFO obteve resultados superiores aos obtidos pelas combinações destas heurísticas construtivas com a heurística de melhoria FT. Esta melhoria se deu tanto na qualidade das soluções geradas, como nos tempos computacionais necessários para resolver o problema. Isto torna a heurística FFO mais promissora para a combinação com as variantes RF21 e RF33 da heurística relaxe-e-fixe. Foram ainda testadas duas possibilidades de tempo limite para a heurística relaxe-e-fixe, sendo eles 1800 e 3600 segundos. No primeiro caso, FFO tem ao menos 1800 segundos para ser executada e mais do que isto nos casos onde a heurística relaxe-e-fixe encontre uma solução antes do tempo limite. Na segunda opção de tempo limite, a fixe-e-otimize é executada apenas para os exemplares nos quais o relaxe-e-fixe encontre uma solução antes do seu tempo limite, pois o tempo limite da heurística construtiva é igual ao tempo limite do método completo. Considerando as melhores variantes de relaxe-e-fixe (RF21 e RF33) e tempo limite, foram geradas 4 variantes (RF21FFO1800, RF21FFO3600, RF33FFO1800 e RF33FFO3600). Para cada uma destas variantes, foram testados 36 conjuntos de parâmetros distintos para a FFO (Tabela 20), tal qual foi feito com as combinações da fixe-e-otimize e as heurísticas construtivas mais simples. Os gráficos de curva de desempenho dos cinco melhores conjuntos de parâmetros das 4 variantes são dados nas Figuras 68, 69, 70 e 71. Os desvios médios obtidos por cada conjunto de parâmetros para cada variante são apresentados nas Tabelas $25,26,27$ e 28 .

A variante RF21FFO1800 com tempo limitado em 1800 segundos obteve desvios percentuais médio variando de $15,05 \%$ até $16,74 \%$, e uma média geral de 15,94\%. O primeiro conjunto de parâmetros (FO1) obteve o melhor resultado médio. Na Tabela 25 são apresentados os resultados de desvio percentual médio de todos os conjuntos de parâmetros, na qual os cinco melhores conjuntos de parâmetros foram destacados em negrito. Estas cinco variantes de parâmetros são comparadas no gráfico de curva de desempenho da Figura 68. 
Apesar da variante FO1 não ter a maior quantidade de melhores soluções, sendo ligeiramente inferior a variante FO7, ela obteve resultado igual ou superior as demais variantes na maior parte da curva. Ela foi superada por alguma outra variante para $\tau<1,0015$, $\tau \in(1,012 ; 1,013)$ e $\tau \in(1,0155 ; 1,0225)$. Além disso, a variante FO1 obteve $100 \%$ de soluções resolvidas com o menor $\tau$, o que a torna a melhor variante deste conjunto de testes. O conjunto de parâmetros FO1 tem partições por períodos e máquinas de tamanho quatro micro-períodos por duas máquinas e sobreposição de dois micro-períodos. As partições por itens e máquinas têm tamanho de dois itens por uma máquina com sobreposição de um item. Finalmente, as partições em forma de cubo têm dimensões de dezesseis micro-períodos por quatro itens, com sobreposição de oito micro-períodos e dois itens.

Tabela 25: Desvio percentual médio (\%) dos 36 conjuntos de parâmetros testados considerando a solução da heurística RF21 limitada em 1800 segundos (RF21FFO1800).

\begin{tabular}{cccccccc}
\hline Variante & Desvio & Variante & Desvio & Variante & Desvio & Variante & Desvio \\
\hline FO1 & $\mathbf{1 5 , 0 5}$ & FO10 & 16,15 & FO19 & 15,61 & FO28 & 16,46 \\
FO2 & 15,84 & FO11 & 15,65 & FO20 & 16,38 & FO29 & 15,77 \\
FO3 & 15,56 & FO12 & 16,14 & FO21 & 15,74 & FO30 & 16,39 \\
FO4 & 15,71 & FO13 & $\mathbf{1 5 , 2 7}$ & FO22 & 16,01 & FO31 & 15,85 \\
FO5 & $\mathbf{1 5 , 3 7}$ & FO14 & 15,91 & FO23 & 15,71 & FO32 & 16,61 \\
FO6 & 15,77 & FO15 & $\mathbf{1 5 , 3 9}$ & FO24 & 16,22 & FO33 & 16,16 \\
FO7 & $\mathbf{1 5 , 4 7}$ & FO16 & 16,13 & FO25 & 16,08 & FO34 & 16,74 \\
FO8 & 15,92 & FO17 & 15,69 & FO26 & 16,51 & FO35 & 16,22 \\
FO9 & 15,91 & FO18 & 15,91 & FO27 & 15,92 & FO36 & 16,55 \\
\hline
\end{tabular}

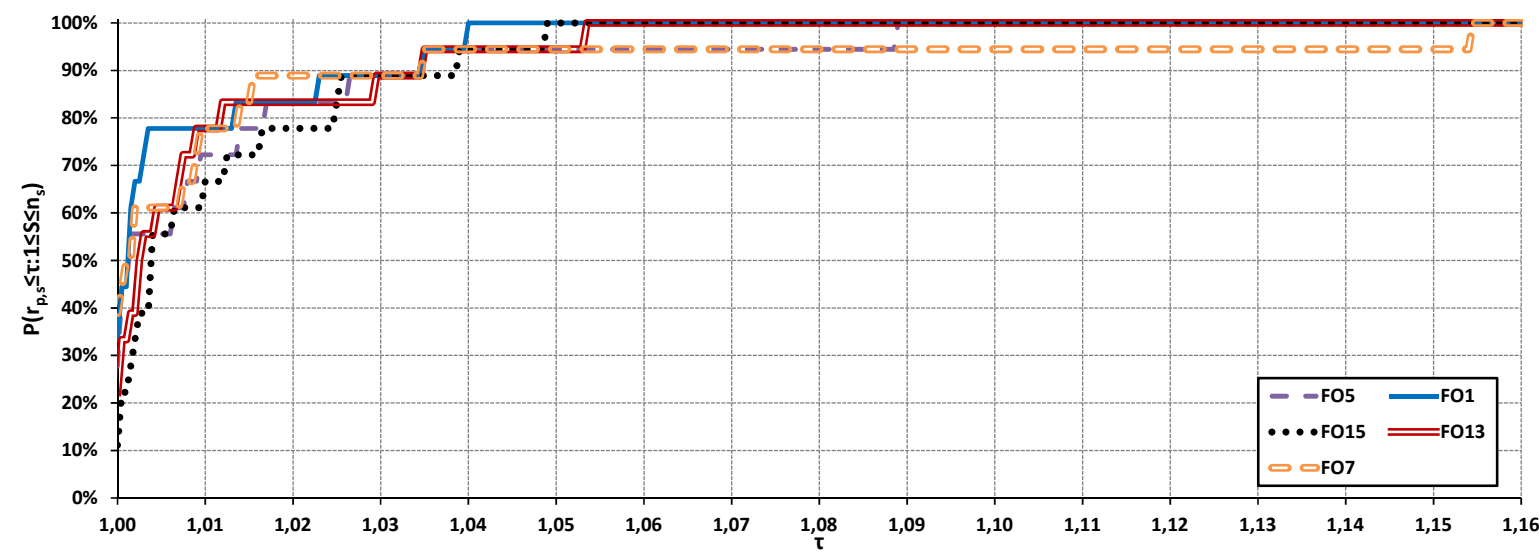

Figura 68: Gráfico de curvas de desempenho dos cinco melhores conjuntos de parâmetros da heurística FFO-RF21 com tempo limite para a heurística relaxe-e-fixe de 1800 segundos.

A variante RF21FFO3600 que tem a heurística relaxe-e-fixe limitada a 3600 segundos obteve resultados inferiores e os melhores conjuntos de parâmetros variaram, sendo que 
apenas dois das cinco melhores conjuntos de parâmetros coincidiram com os testes de 1800 segundos. Os desvios percentuais médios dos testes com a heurística relaxe-e-fixe limitada em 3600 segundos são apresentados na Tabela 26. Um destes dois conjuntos foi a parametrização (FO13), que obteve o menor desvio percentual médio. Os valores médios de desvio percentual variaram entre $16,83 \%$ e 19,49\% e a média geral foi de 18,25\%. Este valor médio foi $2,31 \%$ superior ao encontrado nos testes anteriores, o que sugere que um maior tempo para a heurística de melhoria possa gerar resultados de melhor qualidade. Quando considerados apenas os resultados da melhor variante de cada grupo de testes, no entanto, esta diferença reduz para 1,78\% e quando analisada a variante FO13, a diferença fica igual a 1,56\%. Neste caso, comparando os resultados da Tabela 25 com a Tabela 26, conclui-se que é vantajoso reduzir o tempo de solução da relaxe-e-fixe no caso da variante RF21.

Tabela 26: Desvio percentual médio (\%) dos 36 conjuntos de parâmetros testados considerando a solução da heurística RF21 limitada em 3600 segundos.

\begin{tabular}{cccccccc}
\hline Variante & Desvio & Variante & Desvio & Variante & Desvio & Variante & Desvio \\
\hline FO1 & 18,22 & FO10 & 18,12 & FO19 & 17,89 & FO28 & 19,25 \\
FO2 & 18,30 & FO11 & 18,40 & FO20 & 18,11 & FO29 & 18,05 \\
FO3 & 19,01 & FO12 & 18,62 & FO21 & 18,98 & FO30 & 19,49 \\
FO4 & 18,09 & FO13 & $\mathbf{1 6 , 8 3}$ & FO22 & 18,08 & FO31 & 18,55 \\
FO5 & 17,65 & FO14 & $\mathbf{1 7 , 4 8}$ & FO23 & 18,63 & FO32 & 18,66 \\
FO6 & 17,66 & FO15 & $\mathbf{1 7 , 4 4}$ & FO24 & 18,23 & FO33 & 18,70 \\
FO7 & 18,16 & FO16 & 18,72 & FO25 & 18,29 & FO34 & 18,50 \\
FO8 & 18,00 & FO17 & $\mathbf{1 7 , 1 4}$ & FO26 & 18,74 & FO35 & 17,72 \\
FO9 & $\mathbf{1 7 , 0 9}$ & FO18 & 18,52 & FO27 & 18,69 & FO36 & 18,94 \\
\hline
\end{tabular}

A Figura 69 apresenta as curvas de desempenho das cinco melhores parametrizações com solução inicial gerada pela RF21 limitada em 3600 segundos. A variante FO13 não tem maior quantidade de melhores soluções, sendo pior ou igual a todas as demais variantes neste quesito. No entanto, supera as demais em $\tau=1,002$, sendo ultrapassada apenas nos intervalos $\tau \in(1,014 ; 1,017)$ e $\tau \in(1,019 ; 1,032)$. O desempenho similar entre as variantes FO13 e FO17 dificulta a escolha da melhor opção, no entanto, a melhor média e o fato de chegar a $100 \% \operatorname{com} \tau=1,154$ (FO13) contra $\tau=1,2175$ da variante FO17, torna a primeira variante superior. A parametrização FO13 tem partições de períodos e máquinas com tamanho de oito micro-períodos por uma máquina e sobreposição de quatro micro-períodos. As partições por itens e máquinas têm tamanho igual a dois itens por uma máquina com sobreposição de um item. Por fim, as partições em forma de cubo têm tamanho igual a dezesseis micro-períodos por oito itens. A sobreposição, por sua vez, 
pode ser de oito micro-períodos ou quatro itens.

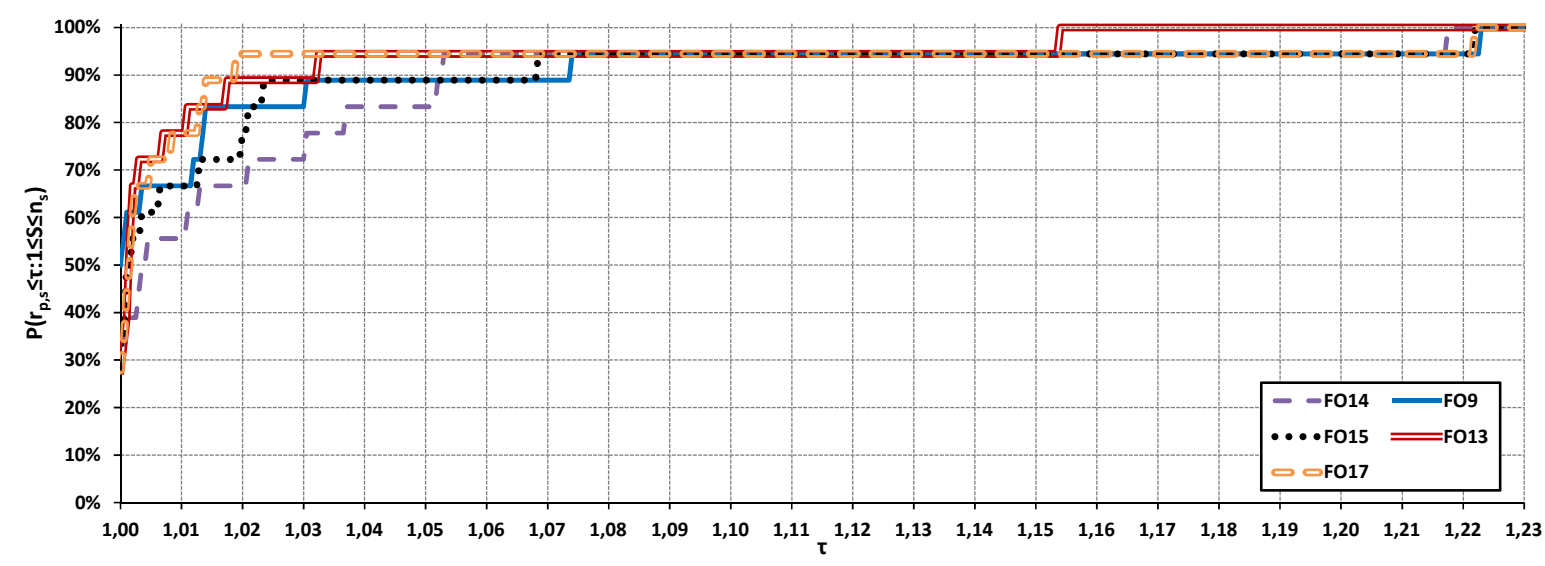

Figura 69: Gráfico de curvas de desempenho dos cinco melhores conjuntos de parâmetros da heurística FFO-RF21 com tempo limite para a heurística relaxe-e-fixe de 3600 segundos.

A Tabela 27 apresenta os resultados médios obtidos pela combinação da heurística FFO com a variante RF33 da relaxe-e-fixe limitada em 1800 segundos. Os resultados médios foram ligeiramente piores com relação aos encontrados nos mesmos testes com a variante RF21 da relaxe-e-fixe, tendo médias variando entre 15,56\% e 18,50\%, contra $15,05 \%$ e $16,74 \%$ do caso anterior. Na média geral, a variante considerando a RF33 limitada a 1800 segundos de execução obteve valor $16,81 \%$, cerca de $0,87 \%$ acima da outra variante com o mesmo tempo. No caso da melhor parametrização, a diferença cai para 0,51\%. As curvas de desempenho apresentadas na Figura 70 demonstram que FO1 foi a segunda melhor parametrização no quesito quantidade de melhores soluções, no entanto, tem desempenho mais estável que as demais. O baixo valor de $\tau$ com que todas as variantes atingem $100 \%$ de soluções é um indício do equilíbrio entre as variantes. Neste caso, a escolha de FO1 como a melhor variante foi feita apenas com base na média.

A Tabela 28 apresenta os resultados médios de desvio percentual dos testes feitos com a relaxe-e-fixe RF33 limitada a 3600 segundos. Três das cinco melhores variantes podem ser encontradas no conjunto de melhores variantes dos testes limitando RF33 em 1800 segundos. Além disso, a diferença de desempenho destes dois testes foi inferior ao que ocorre no caso da RF21. Com limite de 3600 segundos, a variante RF33 obteve valores médio entre $15,50 \%$ e $18,93 \%$, contra $15,56 \%$ e 18,50\% nos testes limitando a heurística construtiva a 1800 segundos. Como a heurística RF33 obteve tempo computacional médio inferior aos da RF21, a heurística fixe-e-otimize pode melhorar uma quantidade maior de soluções nos testes onde a heurística relaxe-e-fixe foi limitada em 3600 segundos. Isto diminuiu a diferença com relação aos testes onde RF33 foi limitada em 1800 segundos, 
Tabela 27: Desvio percentual médio (\%) dos 36 conjuntos de parâmetros testados considerando a solução da heurística RF33 limitada em 1800 segundos.

\begin{tabular}{cccccccc}
\hline Variante & Desvio & Variante & Desvio & Variante & Desvio & Variante & Desvio \\
\hline FO1 & $\mathbf{1 5 , 5 6}$ & FO10 & 17,31 & FO19 & $\mathbf{1 5 , 6 8}$ & FO28 & 17,79 \\
FO2 & 16,80 & FO11 & 16,54 & FO20 & 17,48 & FO29 & 16,54 \\
FO3 & 15,84 & FO12 & 17,83 & FO21 & 15,95 & FO30 & 17,63 \\
FO4 & 17,04 & FO13 & 15,80 & FO22 & 17,63 & FO31 & 16,50 \\
FO5 & 16,13 & FO14 & 16,61 & FO23 & 16,00 & FO32 & 17,56 \\
FO6 & 17,01 & FO15 & $\mathbf{1 5 , 7 1}$ & FO24 & 17,43 & FO33 & 17,44 \\
FO7 & $\mathbf{1 5 , 7 6}$ & FO16 & 17,12 & FO25 & 17,15 & FO34 & 18,50 \\
FO8 & 16,92 & FO17 & $\mathbf{1 5 , 7 4}$ & FO26 & 17,64 & FO35 & 16,71 \\
FO9 & 16,15 & FO18 & 16,44 & FO27 & 16,62 & FO36 & 18,44 \\
\hline
\end{tabular}

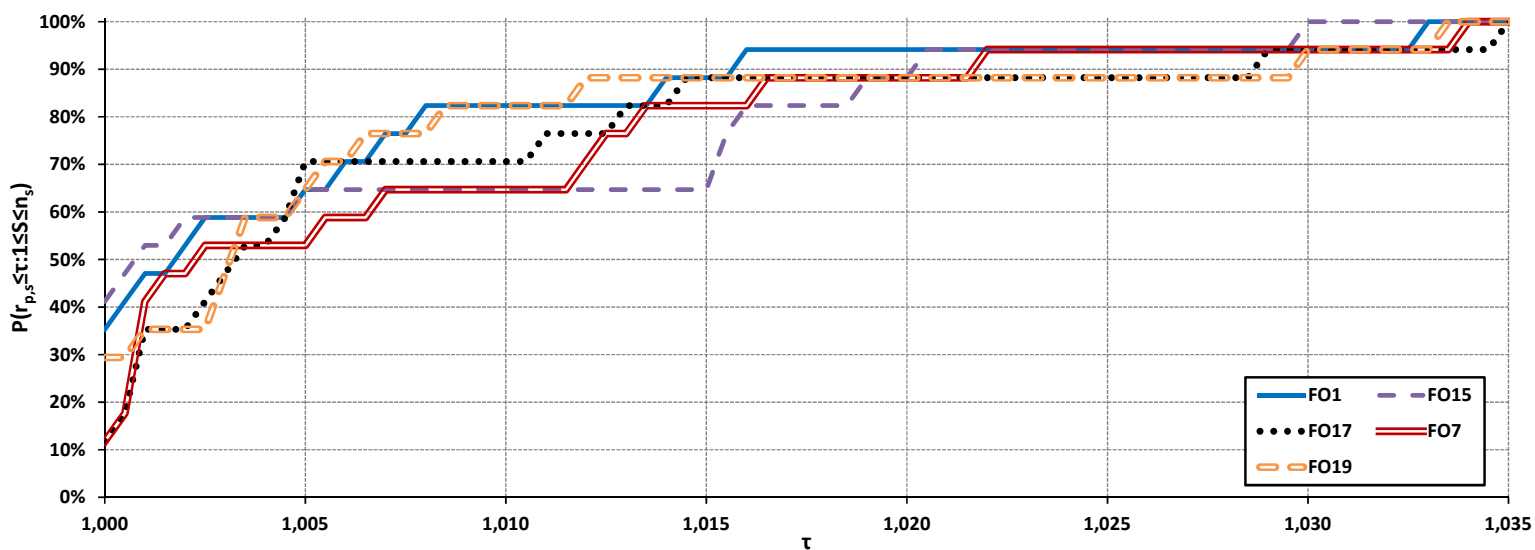

Figura 70: Gráfico de curvas de desempenho dos cinco melhores conjuntos de parâmetros da heurística FFO-RF33 com tempo limite para a heurística relaxe-e-fixe de 1800 segundos.

corroborando com a ideia de que a heurística de melhoria tem maior impacto sobre a solução final e portanto, deve ter maior tempo computacional. Por outro lado, quando comparadas apenas a melhor variante de cada teste, observa-se que os testes com a relaxee-fixe limitada a 3600 segundos obtiveram melhores resultados, indicando que um bom particionamento da fixe-e-otimize pode torná-la eficiente a ponto de melhorar a solução, ainda mais, a partir de uma solução construída de melhor qualidade.

A Figura 71 apresenta as curvas de desempenho das cinco melhores parametrizações considerando a solução inicial da heurística RF33 com tempo limitado em 3600 segundos. Duas parametrizações se destacam com relação as demais, sendo elas as variantes FO13 e FO15. Apesar de ter apenas 22,22\% de melhores soluções, a variante FO15 foi escolhida como a melhor opção, por dominar a maior parte das curvas de desempenho. A partir de $\tau>1,01$, ela não é superada por nenhuma outra variante, sendo no máximo igualada 
Tabela 28: Desvio percentual médio (\%) dos 36 conjuntos de parâmetros testados considerando a solução da heurística RF33 limitada em 3600 segundos.

\begin{tabular}{cccccccc}
\hline Variante & Desvio & Variante & Desvio & Variante & Desvio & Variante & Desvio \\
\hline FO1 & $\mathbf{1 6 , 2 0}$ & FO10 & 17,50 & FO19 & 16,35 & FO28 & 18,41 \\
FO2 & 17,06 & FO11 & 16,95 & FO20 & 17,74 & FO29 & 16,88 \\
FO3 & $\mathbf{1 5 , 8 8}$ & FO12 & 18,19 & FO21 & 16,83 & FO30 & 18,18 \\
FO4 & 17,48 & FO13 & $\mathbf{1 5 , 5 0}$ & FO22 & 17,45 & FO31 & 17,11 \\
FO5 & 16,43 & FO14 & 16,94 & FO23 & 16,81 & FO32 & 18,60 \\
FO6 & 17,33 & FO15 & $\mathbf{1 5 , 5 1}$ & FO24 & 18,11 & FO33 & 16,95 \\
FO7 & 16,46 & FO16 & 17,61 & FO25 & 16,62 & FO34 & 18,30 \\
FO8 & 17,93 & FO17 & $\mathbf{1 6 , 1 3}$ & FO26 & 18,21 & FO35 & 17,35 \\
FO9 & 16,77 & FO18 & 17,36 & FO27 & 17,09 & FO36 & 18,93 \\
\hline
\end{tabular}

em alguns pontos. Além disso, sua média é apenas $0,01 \%$ pior que a variante FO13. A variante FO15 tem partições por períodos e máquinas com oito micro-períodos por uma máquina em cada partição e sobreposição de quatro micro-períodos. As partições por itens e máquinas têm tamanho de dois itens e uma máquina, com sobreposição de um item. As partições em forma de cubo, por sua vez, têm dimensões de vinte e quatro micro-períodos por dois itens. As sobreposições têm dimensões de doze micro-períodos por dois itens.

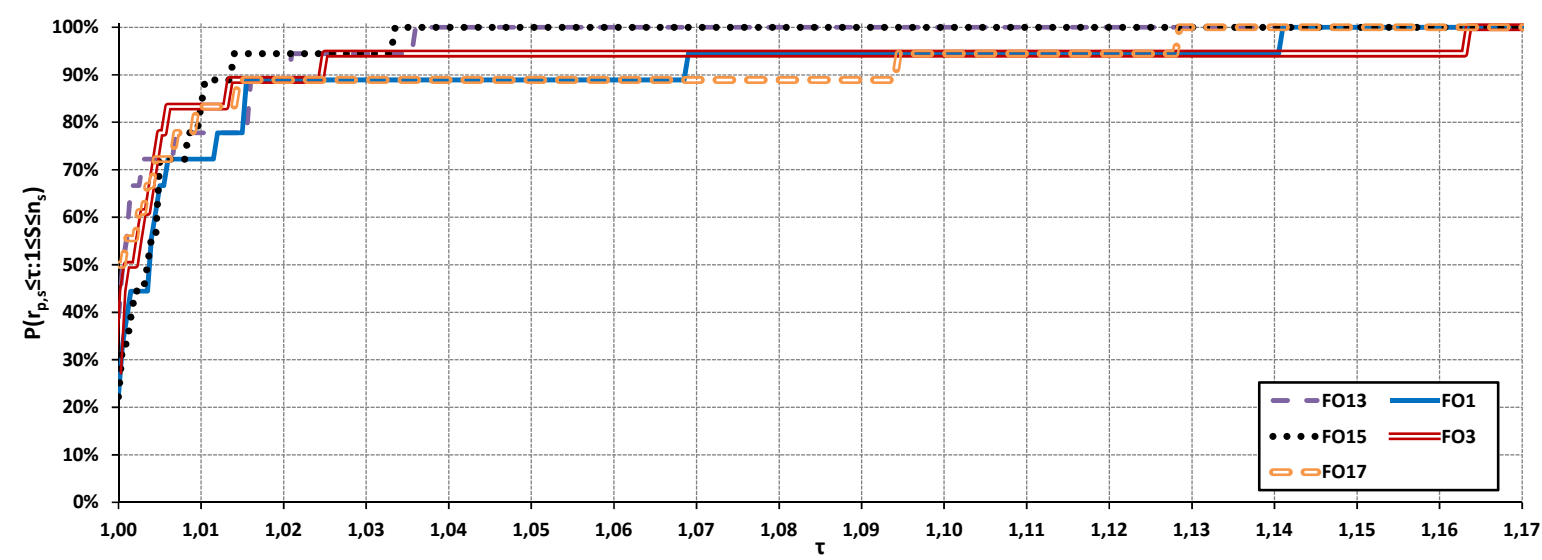

Figura 71: Gráfico de curvas de desempenho dos cinco melhores conjuntos de parâmetros da heurística FFO-RF33 com tempo limite para a heurística relaxe-e-fixe de 3600 segundos.

\subsubsection{Algoritmo genético}

Nesta seção descrevemos os parâmetros utilizados durante os testes do algoritmo genético desenvolvido. Foram feitos dois conjuntos de testes com o algoritmo genético. $\mathrm{O}$ primeiro considera o melhor conjunto de parâmetros obtido nos testes computacionais de 
Furlan et al. (2015). O segundo considera a incorporação da heurística construtiva gulosa baseada em ciclos predefinidos de produção (Seção 5.2.1).

Com base nos resultados computacionais do artigo (FURLAN et al., 2015) e em testes feitos separadamente nesta tese, foi verificado que a heurística construtiva, baseada em arredondamento (Seção 4.2), não apresentou resultados competitivos. Para complementar os resultados do artigo, foram considerados dois conjuntos de parâmetros com configurações distintas. O primeiro conjunto de parâmetros utilizado foi similar ao que obteve o melhor resultado nos testes computacionais de Furlan et al. (2015). Apenas o tamanho da população foi aumentado em $20 \%$ por conta do maior processamento da máquina utilizada. O segundo conjunto de testes se diferencia do primeiro por considerar a adição de soluções construídas por uma variação da heurística HCBC na população inicial. Como a heurística construtiva baseada em arredondamento não apresentou resultados expressivos nos testes anteriores, ela foi substituída pela heurística HCBC. A HCBC apresentou bons resultados e pode ser adaptada para gerar um sub-conjunto de soluções dispersas. Esta adaptação do método foi apresentada na Seção 5.2.1.

Para o primeiro conjunto de parâmetros foi considerada uma população de tamanho 120 e pressão de seleção de $10 \%$. Neste caso, a pressão de seleção indica a porcentagem da população que será eliminada no processo de seleção e substituída pela nova geração de indivíduos. A mutação deve variar entre $1-0,8^{1 /|S|}$ e $1-0,5^{1 /|S|}$, onde $|S|$ indica a quantidade de micro-períodos do horizonte de planejamento, e a probabilidade de cruzamento foi definida em 99\%. A quantidade de passos (divIt) de ajuste da mutação e do nível de diversificação $(\varphi)$ para passar do mínimo $\left(\varphi^{\min }\right)$ ao máximo $\left(\varphi^{\max }\right)$ usada foi de 50 passos. Além disso, utilizou-se o processo de diversificação, o ajuste na quantidade de micro-períodos por período e a população inicial com o dobro do tamanho da população nas demais gerações.

No caso do segundo conjunto de testes, a quantidade de soluções iniciais construídas de forma heurística foi ajustada para 20 soluções. Como a população inicial também tem tamanho dobrado, isso equivale a pouco mais de $8 \%$ da população inicial criada. Como a heurística HCBC apresentou resultados factíveis para todos os exemplares testados, neste segundo conjunto de testes o algoritmo genético pode partir de algumas soluções factíveis, o que pode facilitar o processo inicial de convergência do método. 


\subsection{Resultados computacionais finais}

Os resultados computacionais finais fazem uma comparação dos métodos heurísticos desenvolvidos e também uma comparação com a ferramenta de solução MIP Cplex 12.6. Dentre os métodos desenvolvidos, temos as heurísticas construtivas, as heurísticas de melhoria e duas variantes de um algoritmo genético. Nesta comparação de testes finais foram utilizados todos os 540 exemplares gerados. Como alguns métodos têm passos que dependem de escolhas aleatórias, estes foram executados 5 vezes para cada exemplar de teste, totalizando 2700 execuções cada. As excessões foram os métodos com soluções construídas via heurística relaxe-e-fixe e as variantes do Cplex sem inclusão de solução construída pelas heurísticas HCG e HCBC. Estas exceções foram executadas apenas uma vez para cada exemplar de teste. Na Seção 6.4.1 faremos a comparação das soluções obtidas apenas pelas heurísticas construtivas com base em qualidade e tempo de solução, robustez e análises estatísticas. A comparação entre os métodos finais da Seção 6.4.2, considera o Cplex, 2 versões do algoritmo genético e 6 combinações de heurísticas construtivas e heurísticas de melhoria.

\subsubsection{Comparação de desempenho das heurísticas construtivas}

Esta seção visa comparar apenas os resultados obtidos pelas heurísticas construtivas. Nestes testes não foram incluídas as heurísticas de melhoria. Comparamos a seguir os resultados obtidos pela heurística construtiva gulosa (HCG), pela heurística construtiva baseada em arredondamento (HCBA), pela heurística construtiva baseada em ciclos predefinidos de produção (HCBC) e pela heurística relaxe-e-fixe (RF).

A Figura 72 apresenta as curvas de desempenho das heurísticas construtivas analisadas. As heurísticas relaxe-e-fixe RF21 e RF33 tiveram uma quantidade maior de melhores soluções $(\tau=1)$. RF21 conseguiu encontrar melhores soluções em mais de $50 \%$ dos exemplares, comparado aos demais métodos de solução. Além disso, RF21 domina a variante RF33 totalmente e resolve 99,26\% dos exemplares (536 soluções em 540 exemplares de teste). As heurísticas construtivas HCG e HCBC obtiveram desempenho parecido. Elas têm uma quantidade de melhores soluções abaixo de 20\%, mas tem curvas com crescimento acentuado e conseguem resolver todos os 540 exemplares. Ambas atingem 100\% de soluções resolvidas antes de $\tau=2,04$, ou seja, no pior caso eles geraram soluções com pouco mais do que o dobro do custo das melhores soluções encontradas pelos demais métodos. A heurística HCBA obteve o pior resultado, pois teve quantidade comparável 
de melhores soluções em relação a heurística HCBC, mas sua curva não teve crescimento similar, além de ter encontrado a menor porcentagem de soluções factíveis $(93,96 \%)$.

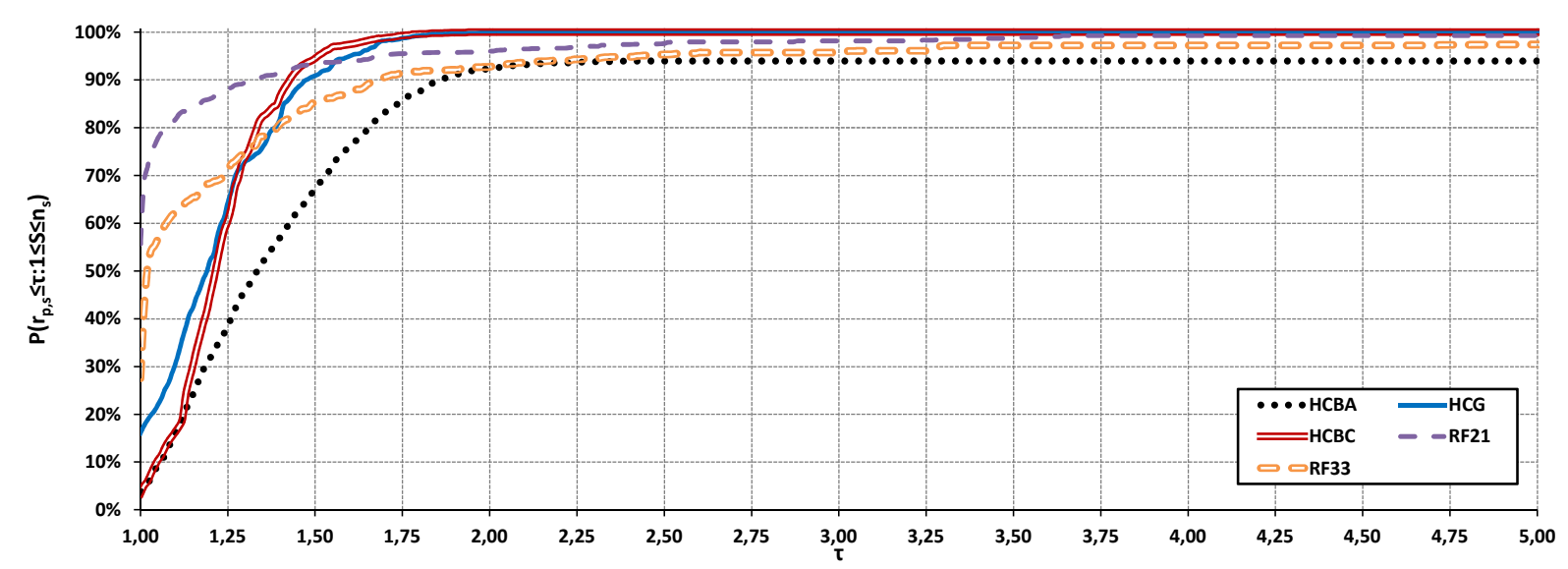

Figura 72: Gráfico de curvas de desempenho das cinco heurísticas construtivas.

A Tabela 29 apresenta os desvios percentuais médios de cada heurística construtiva com relação ao limitante inferior do Cplex após uma hora de execução. As heurísticas construtivas HCG e HCBC foram efetivas principalmente para os exemplares maiores, como é o caso no qual $M=\{1\}$ e $T=\{24\}$, e $M=\{2\}$ e $T=\{16,24\}$. Nestes casos, as heurísticas construtivas mais simples obtiveram resultados comparáveis ou superiores aos encontrados pelo Cplex e pelas heurísticas relaxe-e-fixe. A heurística RF21 obteve melhores resultados gerais, sendo superior ao Cplex em todos os casos agregados por quantidade de máquinas e número de períodos. Isto não indica que tenha ganhado em todos os exemplares, mas apenas que foi melhor na média de cada grupo de testes. A heurística HCBA obteve qualidade de solução reduzida e tempo computacional elevado, podendo ser considerada pouco efetiva. No caso de exemplares com 2 máquinas de papel, ela obteve resultados inferiores a todos os demais métodos. Isto se deve principalmente a alta taxa de infactibilidade na resolução destes testes.

Os tempos computacionais médios obtidos pelas heurísticas são apresentados na Tabela 30. Fica claro nestes resultados que o tempo médio obtido pelas heurísticas HCG e HCBC tem ordem de grandeza diferente dos resultados dos demais métodos. As duas heurísticas geraram resultados em poucos segundos, enquanto os demais métodos são muitas vezes limitados pelo tempo limite de 3600 segundos, por necessitarem do solver.

A combinação dos resultados de desvio percentual e tempo computacional leva a dois apontamentos importantes. O primeiro indica que a heurística RF21 obteve os melhores resultados e em alguns casos, ainda pode contar com o uso de heurísticas de melhoria, dado que o tempo médio obtido é menor que o tempo limite. Por outro lado, apesar 
Tabela 29: Desvio percentual médio (\%) das heurísticas construtivas por quantidade de máquinas e número de períodos.

\begin{tabular}{cccccccc}
\hline M & T & Cplex & HCG & HCBC & HCBA & RF21 & RF33 \\
\hline & 8 & 8,67 & 23,62 & 22,71 & 23,05 & 8,48 & 12,12 \\
1 & 16 & 21,92 & 28,25 & 35,39 & 37,32 & 16,96 & 24,21 \\
& 24 & 29,77 & 27,34 & 36,01 & 43,24 & 23,38 & 30,65 \\
\hline & 8 & 15,22 & 31,81 & 27,25 & 32,66 & 14,05 & 16,84 \\
2 & 16 & 36,58 & 39,01 & 37,11 & 50,35 & 30,42 & 38,08 \\
& 24 & 53,20 & 39,96 & 39,79 & 57,04 & 44,97 & 52,21 \\
\hline Média & 27,56 & 31,67 & 33,04 & 40,61 & 23,04 & 29,02 \\
\hline
\end{tabular}

Tabela 30: Tempo computacional médio (em segundos) das heurísticas construtivas por quantidade de máquinas e número de períodos.

\begin{tabular}{ccccccc}
\hline M & T & HCG & HCBC & HCBA & RF21 & RF33 \\
\hline & 8 & 0,10 & 0,31 & 295,48 & 1266,05 & 922,99 \\
1 & 16 & 0,19 & 0,64 & 503,61 & 2207,56 & 1461,43 \\
& 24 & 0,34 & 1,16 & 725,97 & 2745,39 & 1797,25 \\
\hline & 8 & 0,15 & 1,14 & 324,44 & 1410,81 & 983,14 \\
2 & 16 & 0,29 & 2,97 & 728,98 & 2595,47 & 1727,40 \\
& 24 & 0,58 & 6,13 & 1071,05 & 2914,23 & 1866,70 \\
\hline \multicolumn{2}{l}{ Média } & 0,28 & 2,06 & 608,26 & 2189,92 & 1459,82 \\
\hline
\end{tabular}

de não ter apresentado os melhores resultados em todos os casos, as heurísticas HCG e HCBC foram muito eficientes ao encontrar rapidamente soluções de qualidade razoável em todos os exemplares de teste, conforme as Tabelas 29 e 30. Sendo assim, são boas opções para soluções iniciais em métodos que possuem melhorias.

\subsubsection{Comparação de desempenho dos métodos de solução}

A combinação entre heurísticas construtivas e métodos de melhoria resultou em 15 abordagens de solução completas. Dentre eles, consideramos o Cplex simples (apenas com os parâmetros ajustados) e iniciado com a solução inicial das heurísticas HCG (CplexHCG) e HCBC (Cplex-HCBC). Além disso, temos o algoritmo genético com população inicial totalmente aleatória (AG) e com parte da população gerada a partir da heurística HCBC (AG-HCBC). A combinação das heurísticas construtivas HCG e HCBC com as heurísticas fixe-e-otimize tradicional (FT) e sua variação com mudanças na função objetivo (FFO) resultaram em outros quatro métodos, sendo eles FT-HCG, FT-HCBC, FFO-HCG e FFO-HCBC. Finalmente, a heurística relaxe-e-fixe pura teve duas variantes escolhidas 
para análise e estas duas foram combinadas a heurística FFO, gerando um total de quatro métodos utilizando soluções iniciais construídas via fixe-e-otimize.

Como a comparação entre os 15 métodos de uma única vez se tornaria complexa e possivelmente confusa para se apresentar em gráficos ou tabelas, as comparações foram divididas em quatro grupos e apenas a melhor abordagem de cada grupo é comparada com as demais vencedoras. A divisão foi feita de acordo com as partes que compõem o método da seguinte forma: métodos que utilizam o Cplex como procedimento de melhoria, variantes do algoritmo genético, métodos compostos das heurísticas construtivas simples com melhoria por fixe-e-otimize e, por último, métodos que usam soluções iniciais construídas pela heurística relaxe-e-fixe.

\section{Métodos que utilizam o Cplex como procedimento de melhoria}

O Cplex é uma ferramenta comercial de solução LP/MIP que tem como base um método do tipo Branch-and-cut. Além disso, ele é composto por variada gama de tipos de cortes, heurísticas e outros componentes que o torna apto a resolver uma gama vasta de problemas de forma eficiente. Entretanto, em alguns casos nos quais os problemas crescem em tamanho e complexidade, o Cplex pode não estar apto a gerar soluções de boa qualidade. Em casos extremos, o método não é sequer capaz de gerar soluções factíveis (exemplares de grande porte). Considerando estas dificuldades, foi testada a inserção de soluções iniciais construídas por heurísticas com o intuito de dar um ponto de partida melhor ao Cplex para que este pudesse convergir melhor.

Para os testes com inserção de solução inicial no Cplex, foram utilizadas as heurísticas HCG e HCBC. Elas foram escolhidas por serem capazes de construir soluções factíveis rapidamente (Tabela 30), onde o tempo total de resolução dos exemplares é praticamente mantido na totalidade para o Cplex. A Figura 73 apresenta as curvas de desempenho dos três métodos testados (Cplex, Cplex-HCG e Cplex-HCBC). O método Cplex-HCG obteve os melhores resultados tanto em quantidade de melhores soluções como com relação ao menor valor de $\tau$ para atingir $100 \%$ dos exemplares testados. Desta forma, ele domina as demais curvas e se apresenta como o melhor método desta comparação.

Como a curva do Cplex puro foi totalmente dominado pelas curvas dos outros dois métodos, podemos destacar que a inserção de soluções iniciais construídas pelas heurísticas foi vantajosa. Quando comparamos os resultados do Cplex-HCG com o valor mínimo entre os resultados do Cplex e da heurística HCG, obtemos que em 45,93\% dos casos houve melhoria da solução, em 33,59\% dos casos a solução é igual e 20,48\% das soluções 


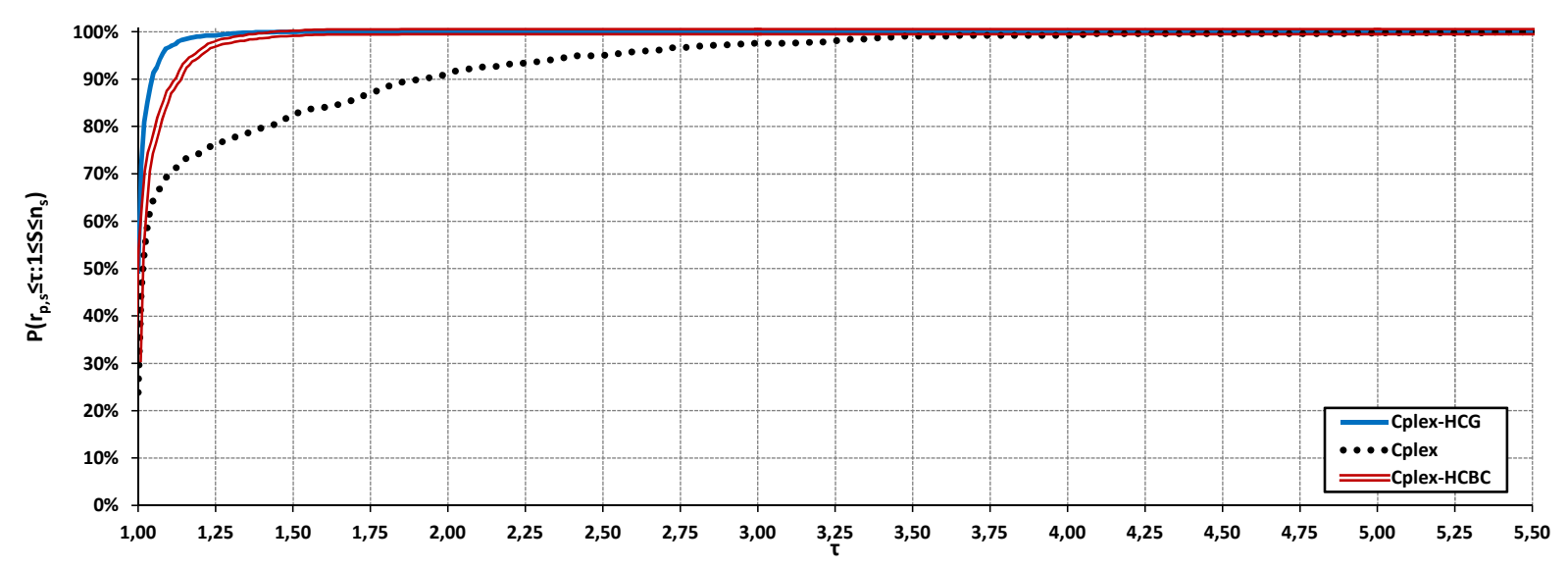

Figura 73: Curva de desempenho dos métodos que utilizam o Cplex como processo de melhoria.

de Cplex-HCG são piores do que a solução mínima dos métodos separadamente. Isso significa que na maioria das vezes uma solução inicial ajuda a convergência do Cplex, no entanto, em alguns exemplares o Cplex não foi capaz de melhorar as soluções ou elas não foram uteis para encontrar a solução final. Além disso, em um quinto dos resultados, a utilização de uma solução inicial piorou a convergência. Provavelmente, esta piora pode ter ocorrido devido a mudanças na aplicação das heurísticas internas do Cplex e na forma como a árvore de decisão do branch-and-cut foi percorrida.

Para complementar a análise comparativa dos métodos, foram realizadas testes de hipóteses não paramétrico (Wilcoxon pareado), visto que as distribuições dos desvios percentuais de exemplares não apresentaram distribuição normal (teste de AndersonDarling). Foram feitos dois testes de hipótese, ambos comparando o melhor método (Cplex-HCG) com os demais. Em ambos os casos a hipótese nula foi rejeitada, obtendo p-valores de $1,36 \cdot 10^{-42}$ quando comparado com o método Cplex-HCBC e de 4,706 . $10^{-122}$ quando comparado com o Cplex parametrizado sem solução inicial. Este resultado combinado ao melhor desempenho apresentado na Figura 73 indica o melhor desempenho do método Cplex-HCG com garantia de $95 \%$ de intervalo de confiança.

\section{Variantes do algoritmo genético}

A Figura 74 apresenta o gráfico de curvas de desempenho do Algoritmo genético desenvolvido (FURLAN et al., 2015) e sua variante considerando as soluções iniciais geradas pela heurística construtiva HCBC. A variante com soluções iniciais na heurística HCBC obteve maior quantidade de melhores resultados e dominou a versão original completamente. Além disso, como a heurística HCBC construiu soluções factíveis para todos os 
exemplares, o método AG-HCBC foi capaz de resolver todos os 540 exemplares, enquanto AG puro obteve soluções factíveis em aproximadamente 530 dos 540 testes. Como algoritmos genéticos são métodos probabilísticos, eles foram executados 5 vezes para cada exemplar de teste. Em alguns casos, uma semente diferente do gerador de números aleatórios pode ter levado o método a convergir para uma solução factível, enquanto com outra semente pode ter fracassado no mesmo exemplar. Para as 2700 execuções, o método AG obteve soluções factíveis em 2653 vezes.

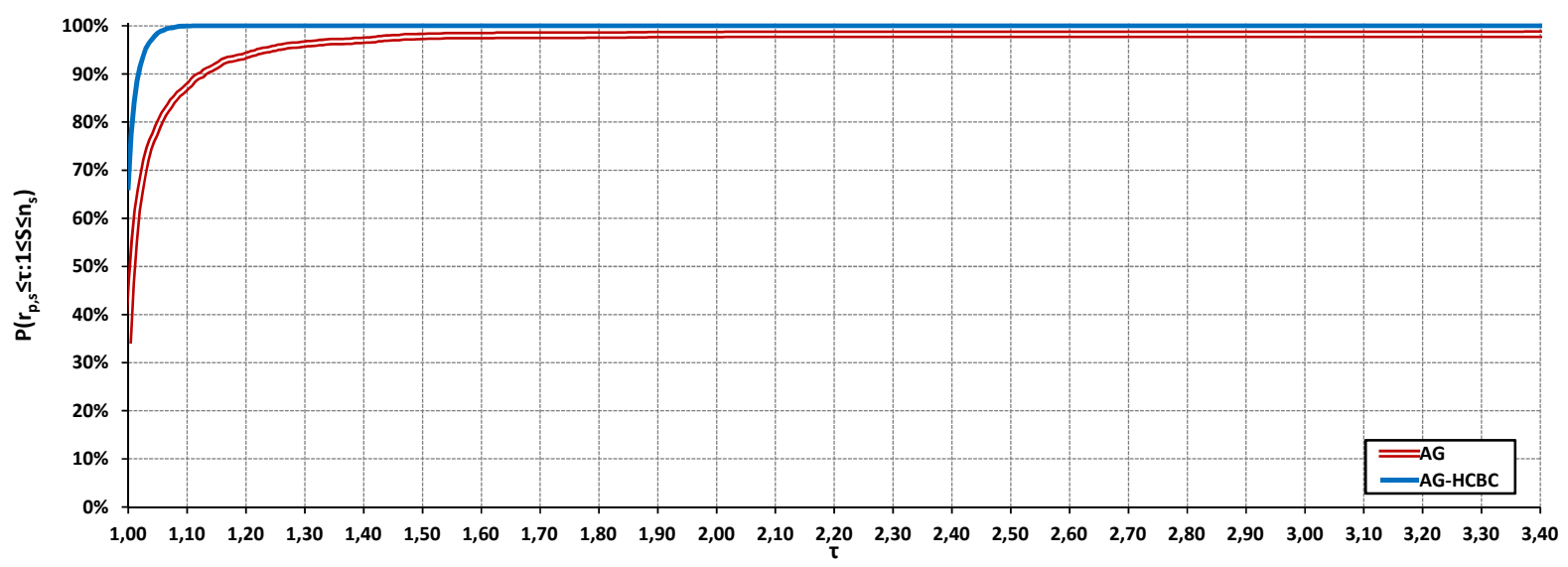

Figura 74: Curva de desempenho das variantes do algoritmo genético.

Além da quantidade maior de soluções factíveis AG-HCBC alcançou $100 \%$ de soluções em $\tau=1,11$, ou seja, suas soluções são no máximo $11 \%$ pior do que as obtidas pelo AG. Isto indica que o uso de soluções iniciais construídas pode ser vantajoso. A vantagem fica mais evidente no caso de exemplares de grande porte com limites produtivos apertados, que não foram resolvidas adequadamente pelo AG puro.

Este resultado entra em conflito com os que foram obtidos no artigo de Furlan et al. (2015), que indicavam resultados inferiores quando a heurística construtiva era utilizada. Porém, como vimos na Seção 6.4.1 a heurística construtiva utilizada no artigo obtém resultados de qualidade e tempo computacional inferiores aos da heurística HCBC na resolução de exemplares de grande porte. Como estes testes são problemáticas do ponto de vista de factibilidade para o algoritmo genético, a heurística construtiva utilizada na ocasião não se mostrava apta a melhorar o algoritmo genético.

Complementando estes resultados, o teste de hipótese nula demonstra que existe diferença com relevância estatística utilizando um intervalo de confiança de 95\%. No teste de Wilcoxon pareado o p-valor obtido foi de $9,8131 \cdot 10^{-106}$. Este valor indica que a hipótese nula pode ser rejeitada. Portanto, AG-HCBC pode ser indicado como superior a AG. 


\section{Métodos compostos pelas heurísticas construtivas simples com melhoria por fixe-e-otimize}

Foram testados os melhores parâmetros de cada uma das quatro combinações entre heurísticas construtivas simples e as duas fixe-e-otimize. As variantes com FT no nome correspondem a heurística fixe-e-otimize tradicional enquanto os métodos composto por FFO dizem respeito as variantes da heurística fixe-e-otimize com mudança na função objetivo. A Figura 75 apresenta as curvas de desempenho dos quatro métodos para os 540 testes gerados. Como as heurísticas construtivas HCG e HCBC podem ter resultados probabilísticos, devido ao processo de factibilização, cada exemplar foi resolvida 5 vezes, totalizando em 2700 execuções de cada método. Os resultados indicam uma superioridade dos métodos com melhoria do tipo FFO contra as variantes do tipo FT. Além disso, as variantes que utilizam a solução inicial da heurística HCG foram superiores as variantes que usam a heurística HCBC. Isto pode indicar que as soluções construídas pela heurística HCG tem características que as tornam mais propensas a melhorias geradas pela fixe-eotimize.

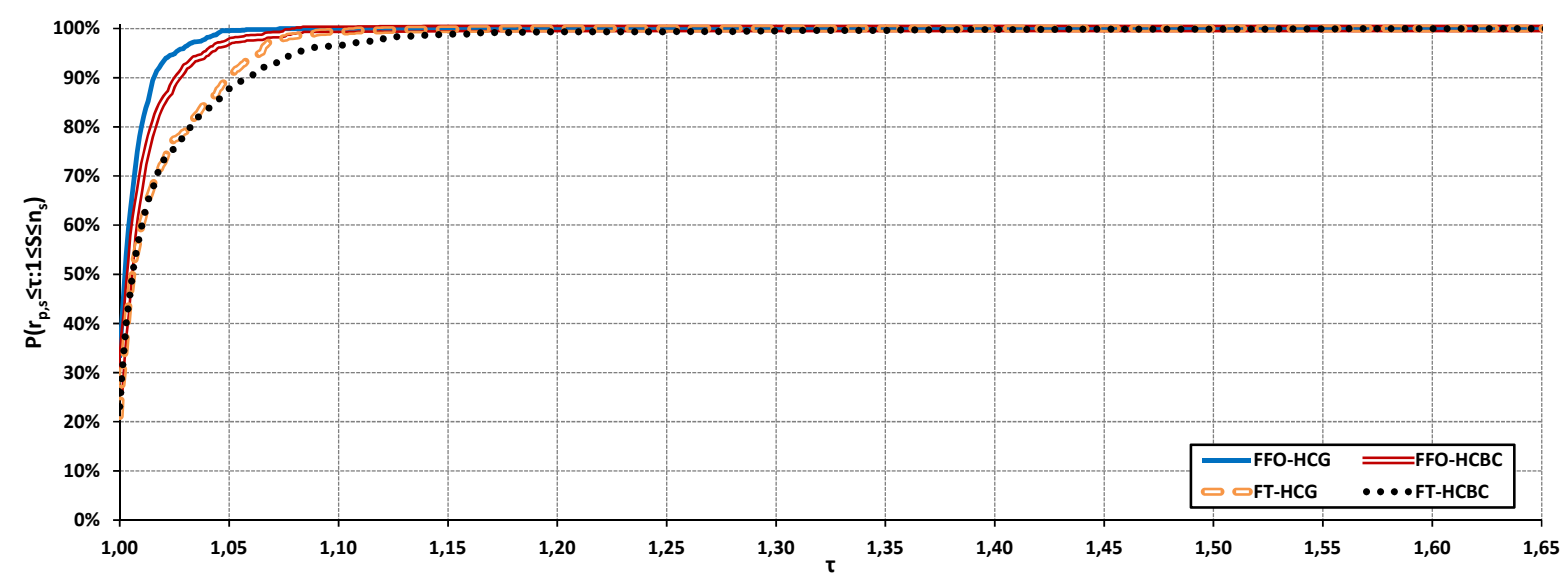

Figura 75: Curva de desempenho dos métodos compostos das heurísticas construtivas simples com melhoria por fixe-e-otimize.

Foram feitos três testes de hipótese, onde foram comparados cada um dos métodos com a melhor combinação (FFO-HCG). Todos os resultados indicaram que a hipótese nula foi rejeitada com intervalo de confiança de 95\%. Quando comparado com a combinação FFO-HCBC, o p-valor obtido foi de $2,81797 \cdot 10^{-23}$. Na comparação com a heurística FTHCG o resultado foi de $2,79989 \cdot 10^{-67}$ e, finalmente, quando comparado com o método FT-HCBC foi obtido um p-valor de $4,25029 \cdot 10^{-64}$. Todos são valores inferiores a $5 \%$, de tal forma que a hipótese nula foi rejeitada em todos os casos. Embasados pelas analises estatísticas e pelo gráfico de curvas de desempenho, FFO-HCG pode ser considerada a 
melhor combinação de heurística construtiva com heurística de melhoria desenvolvidas.

\section{Métodos que usam soluções iniciais construídas pela heurística relaxe-e-fixe}

No caso dos métodos do tipo relaxe-e-fixe foram testadas versões apenas com as heurísticas e combinações com o método de melhoria FFO. Como o método FFO foi superior ao fixe-e-otimize tradicional (FT) tanto em qualidade de solução quanto em tempo computacional quando combinadas as heurísticas construtivas simples (HCG e HCBC), a FFO foi escolhida como método de melhoria a priori para a composição com as heurísticas relaxe-e-fixe RF21 e RF33. Esta escolha foi feita com base em dois fatores, primeiro a heurística relaxe-e-fixe demanda maior esforço computacional do que as heurísticas mais simples e a FFO obteve tempo de solução médio inferior ao FT, possibilitando um investimento maior na construção da solução. Segundo, a FFO obteve resultados melhores para as duas heurísticas construtivas simples, indicando maior robustez e maior efetividade.

A Figura 76 apresenta as curvas de desempenho das heurísticas relaxe-e-fixe RF21 e RF33, e de suas combinações com o método de melhoria FFO limitando o tempo da relaxe-e-fixe em 1800 e 3600 segundos. Neste gráfico pode ser verificado que mesmo com limite de tempo de 3600 segundos para a relaxe-e-fixe, o uso do método de melhoria apresenta resultados superiores a relaxe-e-fixe pura. Isto era esperado, pois no pior caso o método combinado obteria a mesma solução. Além disso, o tempo restante é utilizado para melhorar as soluções construídas pela relaxe-e-fixe. Nos testes com tempo limite de 1800 segundos, ouve uma leve piora na quantidade de exemplares resolvidos para a variante RF33 (RF33FFO1800), pois em um tempo limite inferior a heurísticas relaxe-efixe apresentou mais dificuldade de gerar soluções factíveis nessa variante.

Os resultados das variantes RF21 com a melhoria da FFO foram superiores aos dos métodos compostos com a RF33, tanto em qualidade de solução como em quantidade de soluções factíveis. Enquanto a RF21FFO3600 resolveu 536 dos 540 testes, RF33FFO3600 encontrou soluções factíveis em 517 destes mesmos exemplares. Quanto limitadas em 1800 segundos esta diferença aumenta em 1, dado que RF33FFO1800 resolveu 516 exemplares. Curiosamente, os testes que não são resolvidas por cada uma das relaxe-e-fixe varia, de tal forma que todas os exemplares são resolvidos por pelo menos um dos métodos. Ainda de acordo com as curvas de desempenho, temos a indicação de uma sutil vantagem da combinação RF21FFO1800 sobre as demais.

Foram feitos testes de hipótese comparando a combinação RF21FFO1800 (melhor combinação) com as demais heurísticas. Quando comparado com a heurística RF21FFO3600, 


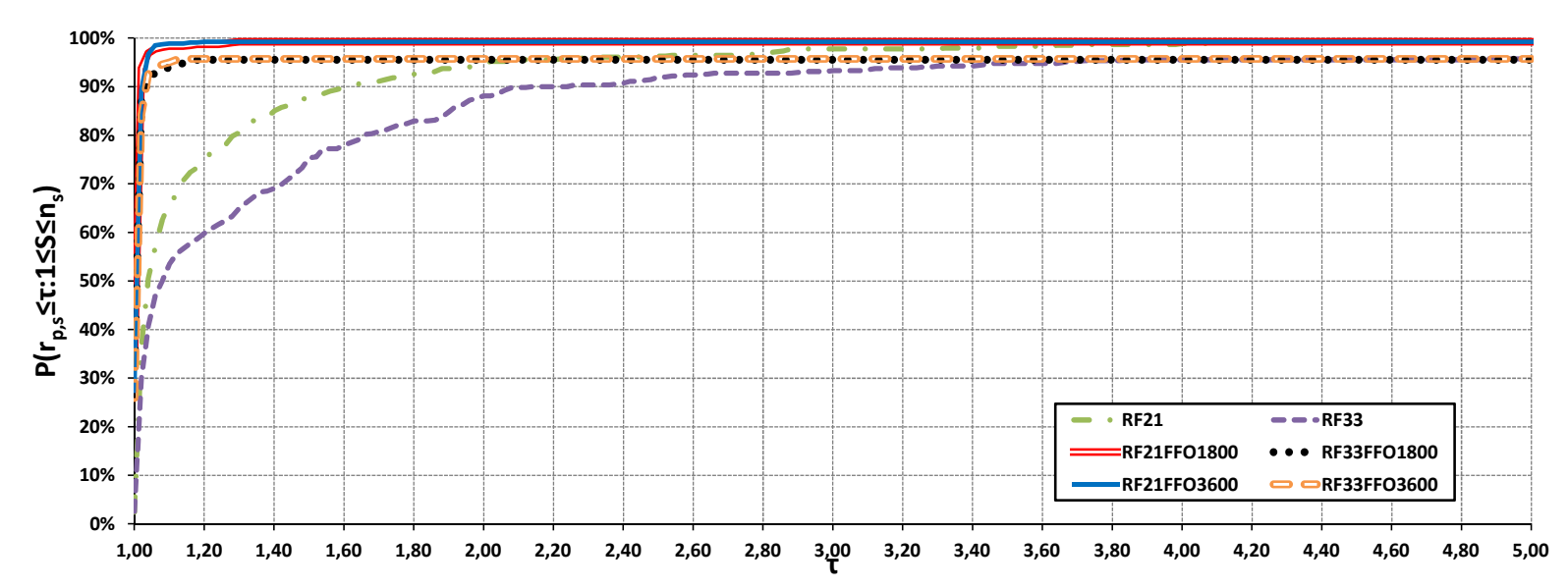

Figura 76: Curva de desempenho dos métodos com solução inicial construídas pela heurística relaxe-e-fixe.

segundo melhor método, o p-valor obtido foi de $6,3239 \cdot{ }^{-5}$. Na comparação com a versão básica do RF21 este valor caí para 9, 1277·10 ${ }^{-85}$. Quando comparado com as variações que usam as soluções iniciais da heurística RF33, os valores obtidos foram $3,9641 \cdot 10^{-6}$ quando comparado ao RF33FFO3600, 0, 0309 contra a combinação RF33FFO1800 e 3, 5692 $10^{-82}$ com relação a versão original do RF33. O maior p-valor encontrado nesta analise foi obtido na comparação com a combinação RF33FFO1800. Mesmo assim, o valor foi inferior a $5 \%$. Isso garante que as distribuições não são iguais em um intervalo de confiança de $95 \%$. Neste caso, RF21FFO1800 pode ser indicada como a melhor combinação de métodos com soluções iniciais construídas pela heurística relaxe-e-fixe e será comparada com os demais métodos que se destacaram.

\section{Comparação final dos métodos}

Para a comparação final dos métodos, foram selecionados os quatro que se destacaram em seus grupos, conforme seções anteriores. A melhor abordagem onde o método de melhoria é a ferramenta de solução MIP Cplex foi obtida com a introdução de solução construída com a heurística construtiva gulosa (HCG), denominada Cplex-HCG. A melhor variante de algoritmo genético foi obtida com a introdução de soluções construídas a partir de uma modificação da heurística construtiva baseada em ciclo de produção (HCBC) e deu origem a variante AG-HCBC. A melhor variante de heurística construtiva simples com procedimento de melhoria via fixe-e-otimize foi obtida combinando a nova variante de fixe-e-otimize com mudança na função objetivo (FFO) e a heurística construtiva gulosa (HCG), dando origem à combinação FFO-HCG. Finalmente, o último método comparado foi a melhor combinação gerada da heurística relaxe-e-fixe $(\mathrm{RF})$ com a nova fixe-e-otimize 
(FFO), denominada RF21FFO1800, por indicar a melhor opção de parâmetros da relaxee-fixe e o tempo limite desta heurística construtiva.

Nesta comparação final, três formas de comparação são aplicadas: gráficos de curvas de desempenho (DM), uma tabela contendo os desvios percentuais médios e outra tabela que indica os tempos computacionais médios, além de testes de hipótese nula. A Figura 77 apresenta as curvas de desempenho dos métodos, que indicam grande variação no desempenho das quatro abordagens. Neste gráfico podemos verificar que a competição mais acirrada ocorre entre os métodos que têm o processo de melhoria feito pela heurística fixe-e-otimize (RF21FFO1800 e FFO-HCG). No entanto, o método RF21FFO1800 é o único a apresentar problemas de factibilidade e no decorrer do gráfico é superado pelos demais métodos. Apesar da quantidade maior de melhores soluções obtidas, o método RF21FFO1800 não pode ser considerado a melhor combinação, devido a esses problemas de factibilidade. Desta forma, a combinação FFO-HCG se apresenta como melhor método, por ter alta qualidade de solução e estabilidade independente do exemplar testado.

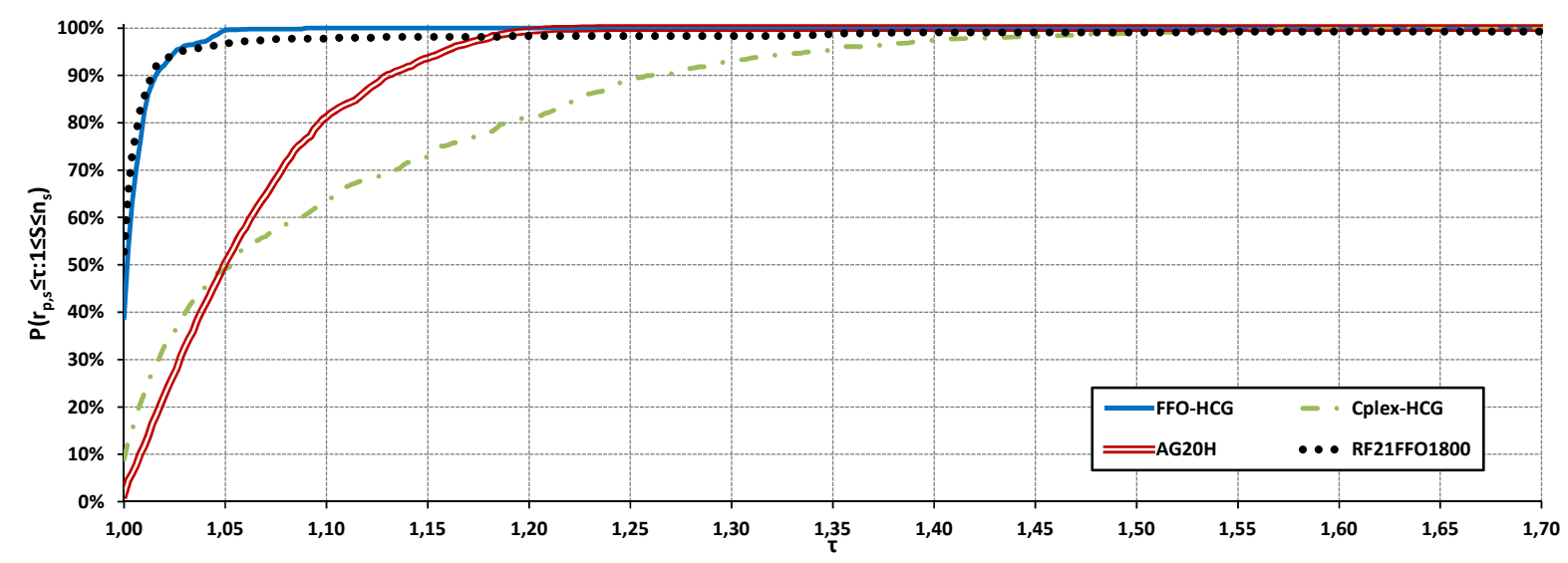

Figura 77: Curva de desempenho dos melhores métodos desenvolvidos.

A Tabela 31 apresenta os desvios percentuais médios de cada método separados por quantidade de máquinas, número de gramaturas distintas e tamanho do horizonte de planejamento. Os melhores resultados por linha estão em negrito e indicam um ganho da heurística RF21FFO1800 na maioria dos grupos, no entanto, a melhor média geral dos desvios percentuais foi obtida pela combinação FFO-HCG. São dois os motivos que causam essa inversão. Primeiro, nos casos onde RF21FFO1800 é melhor, esta melhoria não é superior a $0,63 \%$, considerando os valores médios. Isto faz com que o desempenho do FFO-HCG seja inferior, porém próximo. Adicionalmente, temos os 4 exemplares que não são resolvidas por RF21FFO1800. Neste caso, foram considerados desvios percentuais de $100 \%$ para estes exmplares, para efeito de comparação. Isto fez com que RF21FFO1800 obtivesse um desvio percentual médio de 28,43\% nos testes feitos com 2 máquinas de 
papel, 24 gramaturas distintas e 30 período. Neste grupo, a heurística FFO-HCG obteve uma média de desvio de 9,93\%, cerca de 18,5\% inferior. Desconsiderando este grupo, a heurística RF21FFO1800 teria obtido o melhor desvio médio geral.

Tabela 31: Desvio percentual médio (\%) das quatro melhores abordagens de solução.

\begin{tabular}{|c|c|c|c|c|c|c|}
\hline M & $\mathrm{K}$ & $\mathrm{T}$ & Cplex-HCG & FFO-HCG & AG20H & RF21FFO1800 \\
\hline \multirow{9}{*}{1} & \multirow{3}{*}{8} & 7 & 5,01 & 5,35 & 5,48 & 5,06 \\
\hline & & 15 & 8,25 & 8,07 & 8,22 & 7,81 \\
\hline & & 30 & 8,96 & 4,82 & 5,74 & 4,49 \\
\hline & \multirow{3}{*}{16} & 7 & 19,17 & 18,69 & 21,30 & 18,07 \\
\hline & & 15 & 17,01 & 12,91 & 14,89 & 12,49 \\
\hline & & 30 & 14,14 & 7,09 & 10,18 & 6,89 \\
\hline & \multirow{3}{*}{24} & 7 & 19,68 & 18,71 & 23,07 & 18,73 \\
\hline & & 15 & 22,89 & 14,31 & 18,80 & 14,55 \\
\hline & & 30 & 18,31 & 7,73 & 12,77 & 7,66 \\
\hline \multirow{9}{*}{2} & \multirow{3}{*}{8} & 7 & 10,06 & 10,16 & 12,61 & 10,08 \\
\hline & & 15 & 12,23 & 10,30 & 12,41 & 10,15 \\
\hline & & 30 & 12,28 & 4,92 & 8,40 & 4,72 \\
\hline & \multirow{3}{*}{16} & 7 & 26,90 & 23,83 & 29,36 & 23,32 \\
\hline & & 15 & 27,00 & 14,97 & 20,92 & 14,66 \\
\hline & & 30 & 25,11 & 8,16 & 15,55 & 7,84 \\
\hline & \multirow{3}{*}{24} & 7 & 36,12 & 29,50 & 35,12 & 29,33 \\
\hline & & 15 & 36,08 & 18,43 & 27,48 & 17,91 \\
\hline & & 30 & 27,63 & 9,93 & 20,97 & 28,43 \\
\hline \multicolumn{3}{|c|}{ Média } & 19,27 & 12,66 & 16,85 & 13,45 \\
\hline
\end{tabular}

A Tabela 32 apresenta os tempos computacionais médio obtidos por cada método nesta comparação final. O algoritmo genético utilizou os 3600 segundos do tempo limite em todos os testes, pois o único critério de parada utilizado no algoritmo genético é o tempo computacional limite. Além disso, o Cplex utilizou este mesmo tempo limite em quase todos os testes, com exceção de dez das 2700 execuções feitas, nas quais o Cplex com uso da solução iniciais da heurística HCG conseguiu provar a otimalidade das soluções. Quando comparadas os dois melhores métodos de solução, os tempos computacionais médios foram similares. Houve variações dentre os grupos de exemplares, nas quais cada um dos dois métodos ganhou em tempo computacional do outro. A heurística FFO-HCG tem tempos computacionais em geral melhores nos exemplares com 7 períodos, enquanto RF21FFO1800 é mais rápida para os exemplares maiores.

Por fim, os testes de hipótese nula indicaram que a abordagem FFO-HCG tem resultados significativamente distintos dos demais métodos. Quando comparado com os 
Tabela 32: Tempo computacional médio das quatro melhores abordagens de solução.

\begin{tabular}{rrrrrrr}
\hline M & K & T & Cplex-HCG & FFO-HCG & AG20H & RF21FFO1800 \\
\hline & & 7 & 3553,68 & 113,28 & 3600,30 & 263,63 \\
& 8 & 15 & 3597,49 & 367,74 & 3600,72 & 937,92 \\
& & 30 & 3600,05 & 910,78 & 3601,87 & 1291,56 \\
\cline { 2 - 7 } 1 & & 7 & 3600,02 & 645,44 & 3600,54 & 803,99 \\
& 16 & 15 & 3600,04 & 1725,71 & 3601,23 & 1447,46 \\
& 30 & 3600,47 & 3347,38 & 3603,16 & 2453,96 \\
\hline & & 7 & 3600,03 & 651,74 & 3600,87 & 1243,80 \\
& 24 & 15 & 3600,05 & 1995,94 & 3602,16 & 1916,51 \\
& 30 & 3600,24 & 3498,17 & 3605,60 & 3180,22 \\
\hline & & 7 & 3600,02 & 263,93 & 3600,38 & 556,86 \\
& 8 & 15 & 3600,03 & 901,85 & 3600,98 & 1102,31 \\
& 30 & 3600,06 & 2009,04 & 3602,54 & 1764,55 \\
\hline \multirow{2}{*}{2} & & 7 & 3600,03 & 1239,41 & 3600,84 & 1545,74 \\
& 16 & 15 & 3600,04 & 2863,11 & 3602,25 & 2455,09 \\
& 30 & 3600,31 & 3594,17 & 3606,03 & 3544,48 \\
\hline & & & 3600,05 & 1784,99 & 3601,68 & 2274,61 \\
& 24 & 15 & 3600,16 & 3452,03 & 3604,04 & 3375,29 \\
& 30 & 3600,21 & 3601,95 & 3611,51 & 3242,57 \\
\hline \multirow{2}{*}{ Média } & 3597,39 & 1831,48 & 3602,60 & 1855,59 \\
\hline
\end{tabular}

métodos Cplex-HCG e AG-HCBC, os p-valores obtidos se aproximaram de zero, indicando uma diferença com relevância estatística. No caso da comparação com a abordagem RF21FFO1800, foram feitos três analises distintas, sendo um teste de igualdade. Os outros dois testes foram feitos para indicar qual o método com melhor resultado do ponto de vista da análise estatística. O teste de igualdade resultou em p-valor de $2,08722 \cdot 10^{-14}$, rejeitando a hipótese nula. Quando testamos a hipótese nula com hipótese alternativa de que a heurística FFO-HCG é pior do que a RF21FFO1800, a hipótese nula é aceita com p-valor próximo de 1. No caso da hipótese alternativa contrária, com FFO-HCG é melhor do que RF21FFO1800, o p-valor tendeu a zero e a hipótese nula foi rejeitada. Neste caso, a análise de hipótese nula indica vantagem do método FFO-HCG, possivelmente por ter obtido uma média geral de melhor qualidade. Os testes com resultado infactível podem ter sido outro ponto que levou a análise estatística a indicar FFO-HCG como melhor método desenvolvido. 


\section{Conclusões e perspectivas}

Neste trabalho foi abordado o problema de dimensionamento e sequenciamento de lotes aplicado ao processo integrado de produção de papel e celulose. Neste tipo de indústria, o processo de produção pode ser dividido em dois níveis ou estágios de produção. No primeiro nível encontra-se o digestor, que é responsável pelo cozimento da madeira, transformando-a em celulose virgem. O processo de remoção da celulose encontrada na madeira pode ser químico, térmico, físico ou, como mais comumente encontrado em linhas de produção modernas, termo-químico. O cozimento da madeira também dá origem a um resíduo de produção denominado licor negro fraco. Este resíduo deve ser tratado para evitar contaminações do meio ambiente. Além disso, este resíduo apresenta alto valor calorífico, servindo como combustível para a geração de vapor e energia elétrica. O potencial energético decorrente de sua queima pode abastecer parte das necessidades de vapor e energia da planta produtiva e, em alguns casos, o excedente pode ser revendido para a concessionária de energia local.

No segundo nível do processo produtivo, temos a planta de produção de papel, responsável pela produção das gramaturas de papel demandadas pelos clientes, e a planta de recuperação química, responsável pelo tratamento do licor negro fraco. Além disso, temos os tanques de estoque intermediário de celulose virgem e licor negro fraco, que possibilitam alguma flexibilidade nos planos de produção de cada planta. Para o desenvolvimento de planos de produção de alta qualidade, estes três processos produtivos (planta de celulose, planta de papel e planta de recuperação química) devem trabalhar de forma combinada, levando em consideração todos os limites e capacidades de produção. Isto evita que o plano de produção de uma unidade gere ou solicite recursos além do que as demais unidades poderão consumir ou atender. Tendo em vista que o funcionamento de todas as unidades produtivas se dão de forma contínua e que paradas são permitidas 
apenas em casos especiais (por exemplo, manutenção ou quebra de equipamentos), gerar planos de produção adequados e eficazes para todas as unidades produtivas torna-se uma tarefa complexa e difícil na prática desta indústria.

No decorrer deste trabalho foram desenvolvidos modelos matemáticos, estendendo modelos da literatura para considerar plantas produtivas com múltiplas máquinas produtoras de papel. Além disso, foram geradas famílias de restrições baseadas em práticas industriais verificadas durante visitas feitas a empresas brasileiras e uma empresa portuguesa do setor. Simulações matemáticas com exemplares de teste de pequeno porte foram feitas, verificando os modelos e demonstrando as limitações geradas por tais práticas. Apesar destas limitações, os testes demonstraram a consistência dos modelos e a possibilidade de incorporação destas práticas industriais aos modelos matemáticos.

Devido à dificuldade de solução dos modelos matemáticos em exemplares de grande porte (mais realistas), considerando o solver de otimização Cplex 12.6, foram desenvolvidos algumas abordagens de solução: quatro heurísticas construtivas, duas heurísticas de melhoria e um método híbrido baseado no algoritmo genético. A primeira heurística construtiva, denominada HCG (Heurística construtiva gulosa), se baseia em uma escolha gulosa das gramaturas que serão produzidas a partir dos custos associados. Nesta abordagem de solução, foram considerados micro-períodos de mesmo tamanho e as velocidades de trabalho do digestor foram definidas por meio de um procedimento iterativo. A segunda heurística, nomeada HCBA (Heurística construtiva baseada em arredondamento), se baseia na solução do modelo matemático proposto com as variáveis inteiras relaxadas. A partir desta relaxação, são definidas as probabilidades de escolha de cada gramatura para serem produzidas em cada micro-período.

A terceira heurística construtiva, nomeada HCBC (Heurística construtiva baseada em ciclos predefinidos de produção), baseia-se em ciclos de produção pré-definidos para alocar as gramaturas que serão produzidas em cada máquina de papel. Da mesma maneira que feito na HCG, os micro-períodos tem mesmo tamanho e um procedimento iterativo é utilizado para definir a velocidade de trabalho do digestor em cada micro-período. A quarta e última heurística construtiva é uma abordagem do tipo relaxe-e-fixe, em que foram testadas variadas formas de particionamento para as variáveis de decisão do digestor e das máquinas de papel. Desta forma, tanto a heurística HCG como a HCBC não demandam o uso de ferramentas de solução de problemas lineares e de programação inteira mista (LP/MIP). Por outro lado, a heurística HCBA e a relaxe-e-fixe são dependentes deste tipo de ferramenta. 
As duas heurísticas de melhoria aqui propostas são variações do método fixe-e-otimize, sendo que a primeira é uma versão tradicional desse método, enquanto que a segunda é uma variação com mudanças na função objetivo do problema. O objetivo das heurísticas de melhoria é obter resultados de alta qualidade a partir de solução inicial gerada em alguma das heurísticas construtivas. Neste quesito, a variante aqui proposta foi capaz de melhorar ainda mais as soluções iniciais. A estrutura multi-estágio do problema fez com que o método tradicional de melhoria não fosse tão eficiente como a variante com mudança na função objetivo. A dificuldade encontrada no particionamento das variáveis de controle do digestor, associado à falta de custos diretos desta unidade produtiva, diminuiu a eficiência do método fixe-e-otimize tradicional.

O método híbrido baseado no algoritmo genético proposto envolveu o desenvolvimento de variadas ferramentas. Este método foi construído pela integração de um algoritmo genético, responsável pelo sequenciamento da produção das máquinas de papel e das velocidades do digestor, com uma ferramenta de solução de problemas lineares, que resolve um modelo de programação linear para cada fixação dos sequenciamentos de produção definidos no algoritmo genético. Neste método híbrido foram propostas uma métrica de avaliação da dispersão da população com medida de frequência dos alelos na população e um processo de diversificação baseado nesta métrica. Além disso, foram implementados o uso de indivíduos com tamanho distinto para fazer o ajuste da quantidade de micro-períodos por período e alguns operadores de mutação. Os operadores de seleção e cruzamento foram implementados com base em resultados da literatura. Por fim, uma adaptação da heurística construtiva HCBC foi integrada ao algoritmo genético, com o objetivo de construir parte das soluções iniciais. Isto demonstrou bons resultados, principalmente para exemplares nos quais o algoritmo genético apresentou dificuldades de convergência para soluções factíveis.

Os resultados computacionais destas abordagens de solução foram divididos em três partes. A primeira parte correspondeu à parametrização dos métodos, em que os melhores conjuntos de parâmetros foram escolhidos para cada uma das combinações de métodos testados. Estes testes foram feitos considerando um subconjunto ou todos os exemplares utilizados, de acordo com as características do método que estava sendo parametrizado. Para os métodos que demandavam maiores tempos computacionais, foram utilizadas apenas alguns exemplares. No caso das heurísticas construtivas mais simples, foram definidos os melhores parâmetros considerando todos os exemplares gerados.

A segunda parte dos resultados computacionais focou na escolha do melhor método, 
dentre os grupos de métodos desenvolvidos. Foram definidas as melhores variações de cada um dos seguintes grupos: método composto com Cplex; métodos com heurística construtiva simples e melhoria pela heurística fixe-e-otimize; métodos com solução inicial da heurística relaxe-e-fixe; e métodos baseados em algoritmo genético.

A terceira, e última parte, dos resultados computacionais correspondeu à comparação final dos quatro melhores métodos desenvolvidos, selecionados na segunda parte dos experimentos. Nestes resultados fica claro o desempenho superior dos métodos com melhoria baseada em fixe-e-otimize com mudança na função objetivo (FFO). Tanto o método composto com a heurística construtiva simples HCG, como método que utiliza soluções iniciais da relaxe-e-fixe, foram superiores aos demais na quantidade de melhores soluções. No entanto, houve alguns problemas de infactibilidade para alguns exemplares durante a construção de soluções iniciais neste segundo método via relaxe-e-fixe, o que tornou o primeiro método mais efetivo do que o segundo. Apesar do desempenho superior apresentado pelo Cplex-HCG com relação ao Cplex sem a inserção de solução inicial, este foi o método de pior desempenho médio. O Cplex-HCG teve quantidade de melhores soluções superior à do algoritmo genético, principalmente nos conjuntos de exemplares menores. No entanto, de modo geral, o algoritmo genético teve desempenho melhor em testes de médio e grande porte, tendo uma curva de desempenho superior à obtida pelo Cplex para a maior parte dos exemplares.

Os métodos apresentaram vantagens e desvantagens de acordo com suas características. As heurísticas construtivas HCG e HCBC apresentaram desempenhos adequados em tempos computacionais reduzidos, fatos que propiciam seus usos em conjunto com métodos de melhoria. Já a heurística HCBA não se mostrou tão adequada, pois além de ter um desempenho ruim, apresentou tempos computacionais elevados nos testes de grande porte. Por fim, a heurística relaxe-e-fixe demandou tempos computacionais maiores que as heurísticas construtivas mais simples, no entanto, apresentou qualidade superior com relação às demais heurísticas construtivas. Isto indica que um maior investimento de tempo na construção da solução inicial pode ser vantajoso em alguns conjuntos específicos de exemplares. Além disso, indica que o tempo limite de uma hora aqui imposto nos experimentos computacionais não foi suficiente no caso dos testes de maior porte, pois não foi possível encontrar soluções factíveis para alguns exemplares com horizonte de planejamento de 30 dias, 24 gramaturas distintas e 2 máquinas produtoras de papel.

Mais estudos seriam necessários para avaliar melhor o potencial de aplicação das abordagens desenvolvidas em ambientes industriais. A integração a sistemas de ERP 
e a criação de interfaces mais amigáveis também seriam necessárias para uma melhor aceitação da metodologia de solução. Figueira et al. (2015) é um exemplo de estudo no qual foi utilizado um sistema de suporte a decisão (DSS) para tornar transparente ao usuário o funcionamento do método de solução. Neste caso, foi utilizada uma interface Web para fazer a interação com o usuário.

Adequações nos modelos também seriam necessárias para garantir que os usuários possam interagir com as soluções, fixando e modificando alocações de gramaturas e velocidades durante o processo de solução. Em Rönnqvist (2012) são apresentados quatro exemplos de abordagens que utilizam procedimentos de interação com os usuários. Para cada um dos quatro exemplos são apresentados os desafios verificados, a implementação feita e os resultados e lições aprendidas. Segundo os autores, a otimização é muito boa em encontrar as melhores soluções (ou soluções de alta qualidade), no entanto, nem sempre os modelos matemáticos descrevem com precisão o problema real abordado. Além disso, os usuários das abordagens de solução aplicadas nem sempre têm algum conhecimento de pesquisa operacional (RöNNQVIST, 2012). Neste caso, segundo os autores, é essencial que o desenvolvimento do controle e dos parâmetros da ferramenta de solução seja feito de acordo com o conhecimento dos usuários.

Melhorias nas abordagens de solução desenvolvidas poderiam ser estudadas em trabalhos futuros, para serem capazes de abordar problemas com mais gramaturas, horizontes de planejamento mais longos, ou mesmo com maior detalhamento do processo produtivo. Estudos de tratamento de infactibilidades na heurística relaxe-e-fixe poderiam ser interessantes, visto que esta abordagem se destacou pela qualidade de solução, mas os níveis de infactibilidade a inviabilizaram na escolha de melhor abordagem. O método híbrido baseado no algoritmo genético também poderia receber melhorias, para tentar tonrá-lo mais competitivo com os melhores métodos obtidos. Novos operadores do algoritmo genético e procedimentos de buscais locais poderiam ser incorporados ao método para obter resultados superiores aos atualmente atingidos. A incorporação de alguns passos da heurística fixe-e-otimize para algumas soluções poderia ser uma boa integração para aperfeiçoar este método. Este tipo de hibridização foi testado em Toledo et al. (2013), no qual apresentou resultados de alta qualidade.

Outras possíveis linhas de pesquisa futura incluem agregar problemas ao processo de planejamento integrado da produção como, por exemplo, a integração com o processo de corte de bobinas, a integração com a aquisição de matérias-primas, o roteamento de veículos na entrega dos produtos aos clientes, entre outros. A integração do problema 
de corte ao modelo estudado poderia ser feita tomando como ponto de partida trabalhos da literatura que abordam os problemas de dimensionamento de lotes e corte de bobinas mestre. Exemplos de trabalhos que poderiam ser utilizados como pontos de partida são Poltroniere et al. (2008) e Correia et al. (2012). Poltroniere et al. (2008) consideram o problema de dimensionamento de lotes de múltiplas máquinas de papel sem o sequenciamento da produção. Este problema é associado ao processo de corte unidimensional das bobinas mestre em bobinas menores, de acordo com a demanda dos clientes. No caso de Correia et al. (2012), foi considerado também a possibilidade de corte das bobinas mestre em retângulos de papel.

Aquisição de matérias-primas é a tarefa responsável pela compra de materiais necessários nas diversas etapas produtivas da empresa. Neste contexto, a integração deste problema ao planejamento da produção visaria reduzir custos envolvidos com as atividades de compra, que dependem dos contratos e quantidades compradas. Encomendas maiores poderiam permitir aos fornecedores uma redução dos custos de produção e parte desta redução poderia ser repassada na forma de descontos (SADRIAN; YOON, 1994). Adicionalmente, o processo de seleção dos fornecedores destas matérias-primas é uma tarefa que pode influenciar entre outras coisas, nos preços e na precisão dos prazos de entrega (CHAUDHRY et al., 1993). Exemplos de estudos que consideram este tipo de desconto para todas as unidades adquiridas são Tempelmeier (2002) e Crama et al. (2004). Tempelmeier (2002) considera também casos onde os descontos para as quantidades adquiridas são incrementais. Lee et al. (2013) consideram uma combinação dos dois casos, onde alguns fornecedores aplicam cada uma das regras de desconto. Além disso, a empresa pode optar por um ou múltiplos fornecedores, de acordo com os limites de capacidades, qualidade das matérias-primas, localização, entre outras características dos fornecedores (GHODSYPOUR; O'BRIEN, 1998).

A integração com roteamento de veículos na entrega dos produtos aos clientes teria como objetivo considerar um nível adicional de serviços, gerando decisões que poderiam reduzir custos totais de produção e transporte quando considerados em conjunto. Em alguns casos, por exemplo, a demanda de clientes distintos têm prioridades de atendimento diferentes. Este caso é apresentado em Figueira et al. (2015), no qual os autores consideram uma diferenciação entre demandas normais, demandas que são enviadas para os clientes por navios (exportação) e demandas com prioridade máxima. Para definir a sequência de prioridades de atendimento, os autores utilizam na função objetivo diferentes penalizações associadas ao atraso da entrega de cada tipo de demanda. A menor penalização é designada as demandas normais, enquanto a maior penalização é definida para as 
demandas com prioridade máxima.

Durante as visitas técnicas às empresas brasileiras do setor, foram verificadas algumas práticas utilizadas pelos tomadores de decisão para gera planos de produção. Algumas famílias de restrições foram desenvolvidas para capturas estas práticas, no entanto, mais estudos seriam necessários para verificar a aplicabilidade destas restrições em casos mais realistas. Além disso, uma modificação no paradigma de modelagem considerando modelos matemáticos com sequências predefinidas de gramaturas poderia ser analisada. Estes modelos deveriam reduzir o espaço de busca, e poderiam ser mais facilmente aceitos no cotidiano fabril devido a similaridade com as práticas aplicadas atualmente. Outro ponto importante a favor desta classe de modelos teria a possibilidade de mesclar sequências construídas por métodos de solução com sequências predefinidas pelos próprios tomadores de decisão. Modelos matemáticos de planejamento da produção que consideram sequências predefinidas da produção podem ser encontrados em Günther (2014), Guimarães et al. (2013) e Kang et al. (1999). 


\section{Referências Bibliográficas}

AKARTUNALI, K.; MILLER, A. J. A heuristic approach for big bucket multi-level production planning problems. European Journal of Operational Research, v. 193, n. 2, p. 396-411, 2009.

AMORIM, P.; ANTUNES, C. H.; ALMADA-LOBO, B. Multi-objective lot-sizing and scheduling dealing with perishability issues. Industrial \&f Engineering Chemistry Research, ACS Publications, v. 50, n. 6, p. 3371-3381, 2011.

ARAUJO, S. A. de; ARENALES, M. N.; CLARK, A. R. Lot sizing and furnace scheduling in small foundries. Computers 8 Operations Research, v. 35, n. 3, p. 916 932, 2008.

BALDO, T. A.; SANTOS, M. O.; ALMADA-LOBO, B.; MORABITO, R. An optimization approach for the lot sizing and scheduling problem in the brewery industry. Computers 8 Industrial Engineering, v. 72, n. 0, p. 58 - 71, 2014.

BELO-FILHO, M.; AMORIM, P.; ALMADA-LOBO, B. An adaptive large neighbourhood search for the operational integrated production and distribution problem of perishable products. International Journal of Production Research, v. 0, n. 0, p. 1-19, 2015. Disponível em: <http://dx.doi.org/10.1080/00207543.2015.1010744>.

BERTRAND, J. W. M.; FRANSOO, J. C. Operations management research methodologies using quantitative modeling. International Journal of Operations $\&$ Production Management, v. 22, n. 2, p. 241-264, 2002.

BOUCHRIHA, H.; OUHIMMOU, M.; D'AMOURS, S. Lot sizing problem on a paper machine under a cyclic production approach. International Journal of Production Economics, v. 105, n. 2, p. 318 - 328, 2007.

BRACELPA. Relatório anual de dados do setor. 2014. Http://bracelpa.org.br/bra2/sites/default/files/estatisticas/booklet.pdf. Acessado em: 4 de Agosto de 2015.

BRACELPA. Resultados do setor de celulose e papel. 2014.

Http://bracelpa.org.br/bra2/sites/default/files/conjuntura/CB-064.pdf. Acessado em: 4 de Agosto de 2015. 
BRACELPA. Associação Brasileira de Celulose e Papel. Último acesso: Abril de 2012. Disponível em: <http://www.bracelpa.org.br>.

BUSCHKüHL, L.; SAHLING, F.; HELBER, S.; TEMPELMEIER, H. Dynamic capacitated lot-sizing problems: a classification and review of solution approaches. $O R$ Spectrum, v. 32, p. 231-261, 2010.

CAMARGO, V. C.; MATTIOLli, L.; TOlEDO, F. A knapsack problem as a tool to solve the production planning problem in small foundries. Computers $\&$ Operations Research, Elsevier, v. 39, n. 1, p. 86-92, 2012.

CAMARGO, V. C.; TOLEDO, F.; AlmADA-LOBO, B. Hops-hamming-oriented partition search for production planning in the spinning industry. European Journal of Operational Research, v. 234, p. 266-277, 2014.

CARLSSON, D.; D’AMOURS, S.; MARTEL, A.; RÖNNQVIST, M. Supply chain planning models in the pulp and paper industry. INFOR: Information Systems and Operational Research, v. 47, n. 3, p. 167-183, 2009.

CASTRO, P. M.; RODRIGUES, D.; MATOS, H. A. Cyclic scheduling of pulp digesters with integrated heating tasks. Industrial \& Engineering Chemistry Research, ACS Publications, 2014.

CASTRO, P. M.; WESTERLUND, J.; FORSSELL, S. Scheduling of a continuous plant with recycling of byproducts: A case study from a tissue paper mill. Computers \& Chemical Engineering, v. 33, n. 1, p. 347-358, 2009.

CHAN, H. K.; CHUNG, S. H.; CHAN, T. M. Combining genetic approach and integer programming to solve multi-facility economic lot-scheduling problem. Journal of Intelligent Manufacturing, Springer, v. 23, n. 6, p. 2397-2405, 2012.

CHAUDHRY, S. S.; FORST, F. G.; ZYDIAK, J. L. Vendor selection with price breaks. European Journal of Operational Research, v. 70, n. 1, p. 52 - 66, 1993.

CLAASSEN, G. Mixed integer (0-1) fractional programming for decision support in paper production industry. Omega, Elsevier, v. 43, p. 21-29, 2014.

CLARK, A.; MORABITO, R.; TOSO, E. Production setup-sequencing and lot-sizing at an animal nutrition plant through atsp subtour elimination and patching. Journal of Scheduling, v. 13, p. 111-121, 2010.

CORMEN, T. H.; LEISERSON, C. E.; RIVEST, R. L.; STEIN, C. Introduction to Algorithms, Third Edition. 3rd. ed. Cambridge: The MIT Press, 2009. ISBN 0262033844, 9780262033848.

CORREIA, M.; OLIVEIRA, J. F.; FERREIRA, J. S. Integrated resolution of assignment, sequencing and cutting problems in paper production planning. International Journal of Production Research, v. 0, n. 0, p. 1-18, 2012.

CRAMA, Y.; J, R. P.; TORRES, A. Optimal procurement decisions in the presence of total quantity discounts and alternative product recipes. European Journal of Operational Research, v. 159, n. 2, p. $364-378,2004$. 
DOLAN, E. D.; MORÉ, J. J. Benchmarking optimization software with performance profiles. Mathematical programming, Springer, v. 91, n. 2, p. 201-213, 2002.

DORNELES Árton P.; ARAúJO, O. C. de; BURIOL, L. S. A fix-and-optimize heuristic for the high school timetabling problem. Computers \& Operations Research, v. 52, Part A, n. 0, p. $29-38,2014$.

DREXL, A.; KIMMS, A. Lot sizing and scheduling - survey and extensions. European Journal of operational research, Elsevier, v. 99, n. 2, p. 221-235, 1997.

FERREIRA, D.; CLARK, A. R.; ALMADA-LOBO, B.; MORABITO, R. Single-stage formulations for synchronised two-stage lot sizing and scheduling in soft drink production. International Journal of Production Economics, v. 136, n. 2, p. 255 - 265, 2012.

FERREIRA, D.; MORABITO, R.; RANGEL, S. Solution approaches for the soft drink integrated production lot sizing and scheduling problem. European Journal of Operational Research, v. 196, n. 2, p. $697-706,2009$.

FERREIRA, D.; MORABITO, R.; RANGEL, S. Relax and fix heuristics to solve one-stage one-machine lot-scheduling models for small-scale soft drink plants. Computers E6 Operations Research, v. 37, n. 4, p. $684-691,2010$.

FIGUEIRA, G.; AMORIM, P.; GUIMARãES, L.; AMORIM-LOPES, M.; NEVESMOREIRA, F.; ALMADA-LOBO, B. A decision support system for the operational production planning and scheduling of an integrated pulp and paper mill. Computers $\&$ Chemical Engineering, v. 77, n. 0, p. 85-104, 2015.

FIGUEIRA, G.; SANTOS, M. O.; ALMADA-LOBO, B. A hybrid vns approach for the short-term production planning and scheduling: A case study in the pulp and paper industry. Computers \& Operations Research, Elsevier, v. 40, n. 7, p. 1804-1818, 2013.

FLEISCHMANN, B.; MEYR, H. The general lotsizing and scheduling problem. Operations-Research-Spektrum, Springer, v. 19, n. 1, p. 11-21, 1997.

FURLAN, M.; ALMADA-LOBO, B.; SANTOS, M.; MORABITO, R. Unequal individual genetic algorithm with intelligent diversification for the lot-scheduling problem in integrated mills using multiple-paper machines. Computers $\&$ Operations Research, v. 59, n. 0, p. 33 - 50, 2015. Disponível em: <http://dx.doi.org/10.1016/j.cor.2014.12.008>.

FURLAN, M. M.; SANTOS, M. O. BFO: a hybrid bees algorithm for the multi-level capacitated lot-sizing problem. Journal of Intelligent Manufacturing, Springer US, p. 1-16, 2015. Disponível em: <http://dx.doi.org/10.1007/s10845-014-1030-4>.

GHODSYPOUR, S.; O'BRIEN, C. A decision support system for supplier selection using an integrated analytic hierarchy process and linear programming. International Journal of Production Economics, v. 56-57, p. 199 - 212, 1998.

GILMORE, P. C.; GOMORY, R. E. A linear programming approach to the cutting stock problem-part ii. Operations research, INFORMS, v. 11, n. 6, p. 863-888, 1963.

GOLDBERG, D. E. Real-coded genetic algorithms, virtual alphabets, and blocking. Complex Systems, v. 5, p. 139-167, 1990. 
GOLDBERG, D. E. The design of innovation: lessons from and for competent genetic algorithms. Nova Iorque: Springer, 2002. 248 p.

GöREN, H. G.; TUNALI, S. Solving the capacitated lot sizing problem with setup carryover using a new sequential hybrid approach. Applied Intelligence, Springer US, p. $1-12,2014$.

GOREN, H. G.; TUNALI, S.; JANS, R. A review of applications of genetic algorithms in lot sizing. Journal of Intelligent Manufacturing, Springer, v. 21, n. 4, p. 575-590, 2010.

GOUlimis, C. C.; GOMEZ, L.; KAUKIAINEN, J. A new tool for optimisation-based scheduling of pulp mills. 2014. Http://www.greycon.biz/download/publications/PulpPlan_IPW_2014.pdf. Accessed: 2014-05-26.

GUIMARãES, L.; KLABJAN, D.; ALMADA-LOBO, B. Pricing, relaxing and fixing under lot sizing and scheduling. European Journal of Operational Research, v. 230, n. 2, p. $399-411,2013$.

GUIMARãES, L.; KLABJAN, D.; ALMADA-LOBO, B. Modeling lotsizing and scheduling problems with sequence dependent setups. European Journal of Operational Research, v. 239, n. 3, p. $644-662,2014$.

GüNTHER, H.-O. The block planning approach for continuous time-based dynamic lot sizing and scheduling. Business Research, v. 7, n. 1, p. 51-76, 2014.

HELBER, S.; SAHLING, F. A fix-and-optimize approach for the multi-level capacitated lot sizing problem. International Journal of Production Economics, v. 123, n. 2, p. 247 $256,2010$.

HOLLAND, J. H. Adaptation in natural and artificial systems: an introductory analysis with applications to biology, control, and artificial intelligence. Ann Arbor: University of Michigan Press, 1975.

IBA. Estatísticas da Indústria Brasileira de Árvores de Junho de 2015. 2015.

Http://www.iba.org/images/shared/Cenarios_junho.pdf. Acessado em: 4 de Agosto de 2015.

INCE, B. K.; INCE, O.; CETECIOGLU, Z. Pollution prevention in the pulp and paper industries. [S.1.]: INTECH Open Access Publisher, 2011.

JAMES, R. J.; ALMADA-LOBO, B. Single and parallel machine capacitated lotsizing and scheduling: New iterative mip-based neighborhood search heuristics. Computers $\mathcal{E}$ Operations Research, v. 38, n. 12, p. 1816 - 1825, 2011.

JANS, R.; DEGRAEVE, Z. Modeling industrial lot sizing problems: A review. International Journal of Production Research, v. 46, n. 6, p. 1619-1643, 2008.

JöNSSON, J.; SVENSSON, I.-L.; BERNTSSON, T.; MOSHFEGH, B. Excess heat from kraft pulp mills: Trade-offs between internal and external use in the case of sweden-part 2: Results for future energy market scenarios. Energy Policy, v. 36, n. 11, p. 4186 - 4197, 2008. 
KALLRATH, J.; REBENNACK, S.; KALLRATH, J.; KUSCHE, R. Solving real-world cutting stock-problems in the paper industry: Mathematical approaches, experience and challenges. European Journal of Operational Research, v. 238, n. 1, p. 374-389, 2014.

KANG, S.; MALIK, K.; THOMAS, L. J. Lotsizing and scheduling on parallel machines with sequence-dependent setup costs. Management Science, INFORMS, v. 45, n. 2, p. 273-289, 1999.

KARIMI, B.; GHOMI, S. M. T. F.; WILSON, J. M. The capacitated lot sizing problem: a review of models and algorithms. Omega, v. 31, n. 5, p. $365-378,2003$. ISSN 0305-0483.

KARMARKAR, U. S.; SCHRAGE, L. The deterministic dynamic product cycling problem. Operations Research, INFORMS, v. 33, n. 2, p. 326-345, 1985.

KESKINOCAK, P.; WU, F.; GOODWIN, R.; MURTHY, S.; AKKIRAJU, R.; KUMARAN, S.; DEREBAIL, A. Scheduling solutions for the paper industry. Operations Research, INFORMS, v. 50, n. 2, p. 249-259, 2002.

KOUMOUSIS, V. K.; KATSARAS, C. P. A saw-tooth genetic algorithm combining the effects of variable population size and reinitialization to enhance performance. Evolutionary Computation, IEEE Transactions on, IEEE, v. 10, n. 1, p. 19-28, 2006.

LEE, A. H.; KANG, H.-Y.; LAI, C.-M.; HONG, W.-Y. An integrated model for lot sizing with supplier selection and quantity discounts. Applied Mathematical Modelling, v. 37, n. 7 , p. $4733-4746,2013$.

LUCHE, J. R. D.; MORABITO, R.; PUREZA, V. Combining process selection and lot sizing models for production scheduling of electrofused grains. Asia-Pacific Journal of Operational Research (APJOR), v. 26, n. 03, p. 421-443, 2009.

MALIK, M.; QIU, M. A review of planning and scheduling in the pulp and paper supply chain. In: IEEE. Industrial Engineering and Engineering Management, 2008. IEEM 2008. IEEE International Conference on. Singapore, 2008. p. 1855-1859.

MERCé, C.; FONTAN, G. Mip-based heuristics for capacitated lotsizing problems. International Journal of Production Economics, v. 85, n. 1, p. 97 - 111, 2003.

MEYR, H. Simultaneous lotsizing and scheduling by combining local search with dual reoptimization. European Journal of Operational Research, v. 120, n. 2, p. 311 - 326, 2000.

MEYR, H. Simultaneous lotsizing and scheduling on parallel machines. European Journal of Operational Research, Elsevier, v. 139, n. 2, p. 277-292, 2002.

MICHALEWICZ, Z. A survey of constraint handling techniques in evolutionary computation methods. Evolutionary Programming, v. 4, p. 135-155, 1995.

MOHAMMADI, M.; GHOMI, S. F.; JAFARI, N. A genetic algorithm for simultaneous lotsizing and sequencing of the permutation flow shops with sequence-dependent setups. International Journal of Computer Integrated Manufacturing, Taylor \& Francis, v. 24, n. 1, p. 87-93, 2011. 
POCHET, Y.; WOLSEY, L. A. Production Planning by Mixed Integer Programming (Springer Series in Operations Research and Financial Engineering). Nova Iorque: Springer-Verlag, 2006. ISBN 0387299599.

POLTRONIERE, S.; POLDI, K.; TOLEDO, F.; ARENALES, M. A coupling cutting stock-lot sizing problem in the paper industry. Annals of Operations Research, Springer Netherlands, v. 157, p. 91-104, 2008.

PUCHINGER, J.; RAIDL, G. R. Combining metaheuristics and exact algorithms in combinatorial optimization: A survey and classification. In: Artificial Intelligence and Knowledge Engineering Applications: A Bioinspired Approach. Heidelberg: Springer, 2005. v. 3562 , p. $41-53$.

REINELT, G. The Traveling Salesman: Computational Solutions for TSP Applications. Berlin, Heidelberg: Springer-Verlag, 1994. ISBN 3-540-58334-3.

RESPICIO, A.; CAPTIVO, M.; RODRIGUES, A. A DSS for production planning and scheduling in the paper industry. In: International Conference On Decision Making and Decision Support in the Internet Age. Cork: University College Cork, 2002. p. 298-308.

RIZK, N.; MARTEL, A.; D'AMOURS, S. Production planning in the pulp and paper industry. In: Administrative Sciences Association of Canada Conference. Quebec: Laval University, 2004.

RöNNQVIST, M. Or challenges and experiences from solving industrial applications. International Transactions in Operational Research, v. 19, n. 1-2, p. 227-251, 2012. ISSN 1475-3995.

SADRIAN, A. A.; YOON, Y. S. A procurement decision support system in business volume discount environments. Operations Research, v. 42, n. 1, p. 14-23, 1994.

SAHLING, F.; BUSCHKüHL, L.; TEMPELMEIER, H.; HELBER, S. Solving a multi-level capacitated lot sizing problem with multi-period setup carry-over via a fix-and-optimize heuristic. Computers $\& 3$ Operations Research, v. 36, n. 9, p. 2546-2553, 2009.

SANTOS, M. O.; ALMADA-LOBO, B. Integrated pulp and paper mill planning and scheduling. Computers \& Industrial Engineering, v. 63, n. 1, p. 1 - 12, 2012.

SANTOS, M. O.; MASSAGO, S.; ALMADA-LOBO, B. Infeasibility handling in genetic algorithm using nested domains for production planning. Computers \& Operations Research, v. 37, n. 6, p. 1113 - 1122, 2010.

SCHAIBLE, S.; IBARAKI, T. Fractional programming. European Journal of Operational Research, v. 12, n. 4, p. 325 - 338, 1983.

SCHUMACHER, K.; SATHAYE, J. Productivity and Energy Efficiency. 1999.

SCHUTTEN, J. M. J. Shop floor scheduling with setup times: Efficiency versus leadtime performance. 177 p. Tese (Doutorado) - University of Twente, Enschede, 1996. 
SILVA, M. d. S. A.; FERREIRA, L. P. C.; REIS, M. L.; ARAGAO, M. V. P. de. Modelo para o planejamento tático integrado da produç ao e distribuiçao de papel e celulose. 2014.

SLACK, N.; CHAMBERS, S.; JOHNSTON, R. Administração da Produção. São Paulo: Atlas, 2009.

SPEARS, W. M.; JONG, K. A. D. An analysis of multi-point crossover. In: Foundations of Genetic Algorithms. San Mateo: Morgan Kaufmann, 1990.

STADTLER, H. Multilevel lot sizing with setup times and multiple constrained resources: Internally rolling schedules with lot-sizing windows. Operations Research, v. 51, n. 3, p. 487-502, 2003.

STADTLER, H.; SAHLING, F. A lot-sizing and scheduling model for multi-stage flow lines with zero lead times. European Journal of Operational Research, v. 225, n. 3, p. 404 $-419,2013$.

SVENSSON, I.-L.; JöNSSON, J.; BERNTSSON, T.; MOSHFEGH, B. Excess heat from kraft pulp mills: Trade-offs between internal and external use in the case of sweden-part 1: Methodology. Energy Policy, v. 36, n. 11, p. 4178 - 4185, 2008.

TEMPELMEIER, H. A simple heuristic for dynamic order sizing and supplier selection with time-varying data. Production and Operations Management, Blackwell Publishing Ltd, v. 11, n. 4, p. 499-515, 2002.

TOledo, C. F. M.; ARANTES, M. d. S.; OliveiRA, R. R. R.; AlMADA-LOBO, B. Glass container production scheduling through hybrid multi-population based evolutionary algorithm. Applied Soft Computing, Elsevier, v. 13, n. 3, p. 1352-1364, 2013.

TOLEDO, C. F. M.; FRANçA, P. M.; MORABITO, R.; KIMMS, A. Multi-population genetic algorithm to solve the synchronized and integrated two-level lot sizing and scheduling problem. International Journal of Production Research, Taylor \& Francis, v. 47, n. 11, p. 3097-3119, 2009.

TOLEDO, C. F. M.; OLIVEIRA, L.; PEREIRA, R. F.; FRANÇA, P. M.; MORABITO, R. A genetic algorithm/mathematical programming approach to solve a two-level soft drink production problem. Computers \& Operations Research, v. 48, p. 40-52, 2014.

TOLEDO, C. F. M.; OLIVEIRA, R. R. R. de; FRANçA, P. M. A hybrid multi-population genetic algorithm applied to solve the multi-level capacitated lot sizing problem with backlogging. Computers \& Operations Research, v. 40, n. 4, p. 910 - 919, 2013.

TOSO, E. A.; MORABITO, R.; CLARK, A. R. Lot sizing and sequencing optimisation at an animal-feed plant. Computers 8 Industrial Engineering, v. 57, n. 3, p. 813 - 821, 2009.

VIDAL, T.; CRAINIC, T. G.; GENDREAU, M.; LAHRICHI, N.; REI, W. A hybrid genetic algorithm for multidepot and periodic vehicle routing problems. Operations Research, v. 60, n. 3, p. 611-624, 2012. 
WHITLEY, D. A genetic algorithm tutorial. Statistics and computing, Springer, v. 4, n. 2, p. 65-85, 1994.

WOLSEY, L. A. Solving multi-item lot-sizing problems with an mip solver using classification and reformulation. Management Science, v. 48, n. 12, p. 1587-1602, 2002.

XIAO, J.; ZHANG, C.; ZHENG, L.; GUPTA, J. N. D. Mip-based fix-and-optimise algorithms for the parallel machine capacitated lot-sizing and scheduling problem. International Journal of Production Research, v. 51, n. 16, p. 5011-5028, 2013.

ZHU, X.; WILHELM, W. E. Scheduling and lot sizing with sequence-dependent setup: A literature review. IIE transactions, v. 38, n. 11, p. 987-1007, 2006. 